
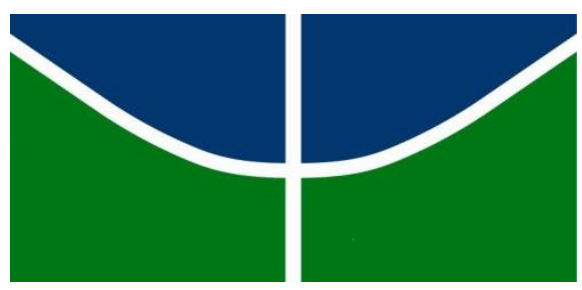

UNIVERSIDADE DE BRASÍLIA CENTRO DE EXCELÊNCIA EM TURISMO

PÓS-GRADUAÇÃO STRICTO SENSU

MESTRADO PROFISSIONAL EM TURISMO

FERNANDA MATOS PARENTE

\title{
IMPACTOS SOCIAIS DA POLÍTICA PÚBLICA DE QUALIFICAÇÃO EM TURISMO, PRONATEC TURISMO, NA INCLUSÃO DE JOVENS E ADULTOS NO MUNDO DE TRABALHO DO SETOR.
}


Ficha catalográfica elaborada automaticamente, com os dados fornecidos pelo(a) autor(a)

MATOS PARENTE, FERNANDA

MF363i IMPACTOS SOCIAIS DA POLÍTICA PÚBLICA DE QUALIFICAÇÃO BM TURISMO, PRONATEC TURISMO, NA INCLUSÃO DE JOVENS E ADULTOS NO MUNDO DE TRABALHO DO SETOR. / FERNANDA MATOS PARENTE; orientador Marutschka Martini Moesch . -- Brasilia, 2017. $271 \mathrm{p}$.

Dissertação (Mestrado - Mestrado Profissional em Turismo) -- Universidade de Brasilia, 2017.

1. Políticas Públicas de qualificação em Turismo 2. PRONATEC Turismo . 3. Formação e Qualificação Profissional em Turismo . 4. Inclusão Social pelo Turismo. 5. Desenvolvimento humano. I. Martini Moesch, Marutschka, orient. II. Título. 


\section{IMPACTOS SOCIAIS DA POLÍTICA PÚBLICA DE QUALIFICAÇÃO EM TURISMO, PRONATEC TURISMO, NA INCLUSÃO DE JOVENS E ADULTOS NO MUNDO DE TRABALHO DO SETOR.}

Dissertação apresentada ao Programa de Mestrado Profissional em Turismo da Universidade de Brasília: Turismo, Cultura e Desenvolvimento Regional, na linha de pesquisa de Desenvolvimento, Políticas Públicas e Gestão no Turismo, como requisito parcial para a obtenção do título de mestre.

Orientadora: Prof ${ }^{a}$. Dr ${ }^{\underline{a}}$ Marutschka Martini Moesch.

Brasília

2017 


\section{IMPACTOS SOCIAIS DA POLÍTICA PÚBLICA DE QUALIFICAÇÃO EM TURISMO, PRONATEC TURISMO, NA INCLUSÃO DE JOVENS E ADULTOS NO MUNDO DE TRABALHO DO SETOR.}

Dissertação apresentada como requisito parcial para obtenção do grau de Mestre em Turismo, Centro de Excelência em Turismo, da Universidade de Brasília.

Aprovada em 7 de março de 2017.

Marutschka Martini Moesch (Orientadora)

Doutora em Ciências da Comunicação pela Universidade de São Paulo (2004)

Universidade de Brasília

Luiz Carlos Spiller Pena

Doutor em Engenharia Civil pela Universidade Estadual de Campinas (2009)

Universidade de Brasília

Silvana do Rocio de Souza (Membro externo)

Doutora em Geografia pela Universidade Federal do Paraná (2011)

Universidade Federal do Paraná 
Aos que sorriem, amam, compreendem, buscam, batalham, trabalham, estudam, e, não temem às dificuldades. 


\section{AGRADECIMENTOS}

Tenho tanto a agradecer: pela vida, pelas oportunidades, que apesar das tempestades sempre se fazem "presente", sim, um presente travestido de novas possibilidades, caminhos, escolhas, amizades, reflexões e construção.

Agradeço a força que move o universo que nos possibilita ter esperança em um mundo melhor, com mais amor, amizades sinceras, gentilezas, sorrisos, educação, responsabilidade, reconhecimento e gratidão.

Nessa trajetória de (re)construção do conhecimento minha família sempre esteve presente: Apoena, Luca, Malu, Marta, Zé, Dani, Marcelo, Ana Sofia, Lê, Arlete, cada um do seu modo, mas, garantindo momentos de amor e alegrias, que trazem paz; sabores que aguçam; respeito que prevalece; cultura, sonoridades, agradáveis ao ouvido, que trazem tranquilidade e reflexões. Família vocês me completam, estimulam, instigam, auxiliam, protegem, fazem bem a alma e ao coração.

Na dialética do concreto tenho muito a agradecer a Professora Maru, minha querida orientadora: mulher travestida de amor e conhecimento, que acolhe, encanta pelos gestos, gentilezas e enorme simpatia. Você me inspira a ser uma pessoa e profissional melhor. Aos professores que trilharam junto comigo este caminho: Biagio, Spiller, Silvana, seus ensinamentos instigaram a buscar mais, refletir mais e construir um novo conhecimento.

Aos pequenos momentos com as amigas especiais, regados de sorrisos, cafés, doces e afetos.

Não posso esquecer-me de agradecer a acolhida do Centro de Excelência em Turismo, que me trouxe novas amizades, conhecimentos e oportunidades na investigação e na constituição do saber, pessoas que contribuíram e complementaram esse novo caminho, me possibilitando vislumbrar alternativas antes distantes.

Agradeço ao Núcleo de Políticas Públicas em Turismo (NPPT/CET) pela oportunidade de participação como pesquisadora no Projeto Concepção da Política Nacional de Formação Profissional em Turismo, a partir das Diretrizes de 
qualificação e da Pesquisa avaliativa dos arranjos territoriais possibilitadores da qualificação em turismo, que me possibilitou acesso aos dados que compõem a análise de conteúdo desta pesquisa. 


\begin{abstract}
A principal meta da educação é criar homens que sejam capazes de fazer coisas novas, não simplesmente repetir o que outras gerações fizeram. Homens que sejam criadores, inventores e descobridores. A segunda meta da educação é formar mentes que estejam em condições de criticar, verificar e não aceitar tudo que a elas se propõe. (Jean Piaget)
\end{abstract}




\section{RESUMO}

A educação profissional dos trabalhadores do turismo no País representa um grande desafio diante dos inúmeros obstáculos que se constatam como a ausência de uma política consistente; a inadequação das propostas curriculares; o despreparo de formadores; a falta de formação e qualificação profissional e vocacional para os cargos de nível operacional, técnico e superior nos setores privado e público (profissionais, empresários e gestores públicos) somado a uma educação básica pouco qualificada que impede a continuidade da formação profissional. Este contexto vem impedindo o círculo virtuoso que poderia proporcionar pela educação profissional, geração de empregos qualificados, renda formal, inclusão social e desenvolvimento humano. Esta pesquisa tem como objetivo analisar a efetividade das políticas de qualificação em Turismo e Hospitalidade implantadas pelo Ministério do Turismo (MTur), no período 2012-2015, na inclusão de jovens e adultos no mundo do trabalho. $O$ indicador inclusão social pela educação, formação e profissionalização foi aplicado para analisar as evidências apresentadas pelos egressos do PRONATEC Turismo. O recorte espacial da pesquisa é delimitado pelas 12 cidades sedes onde ocorreu a Copa do Mundo de Futebol FIFA 2014. Utilizou-se do Materialismo Histórico Dialético como método e a metodologia proposta será de análise documental a partir de Cellar (2008) e de conteúdo por Bardin (2011), as quais discutirão a luz das categorias operatórias: inclusão social, desenvolvimento humano e educação profissional possibilitadora de construção de carreiras. Documentos do MTur, como: relatórios, portarias, a pesquisa avaliativa dos arranjos territoriais possibilitadores da qualificação em turismo, possibilitaram a construção de evidências referentes ao processo de implementação do Programa. É necessário que haja um esforço conjunto entre o governo, as empresas do setor e o sistema educacional para que a educação profissional proporcione 0 desenvolvimento humano, portanto, emancipatório dos trabalhadores do turismo, que não os reduza a mão de obra empregável nos momentos de crescimento da economia e descartáveis por não atenderem as transformações do mundo do trabalho e crises econômicas.

Palavras-chave: 1. Políticas Públicas de qualificação em Turismo 2. PRONATEC Turismo 3. Formação e Qualificação Profissional em Turismo 4. Inclusão Social pelo Turismo 5. Desenvolvimento humano. 


\begin{abstract}
The professional education of workers in the tourism sector, in Brazil, faces huge challenges such as the lack of an effective policy, inadequacy of curriculum proposals, unprepared instructors, lack of professional and qualified job training in all levels (operational, technical, and academic) in public and private sectors (professionals, entrepreneurs, managers). The situation is aggravated by a low quality basic education, which inhibits the continuity of professional education. These problems prevent the existence of a virtuous cycle that could allow, through professional education, the generation of skilled jobs, formal income, social inclusion and human development. In this context, the main purpose of this research is to analyze the effectiveness of the Tourism and Hospitality qualification policies, implemented by the Ministry of Tourism (MTur) that aims to drive young and adults into the job market, during the 2012-2015 period. An indicator of social inclusion through education, training and professionalization was used as tool to analyze the conditions of the workers that participated in one of the programs that resulted from the application of MTur policies: the PRONATEC Tourism Program. The study sample includes twelve Brazilian cities that hosted the FIFA world soccer cup 2014. Using dialectical and historical materialism as the backbone methodology, it was performed a documental analysis according to Cellar (2008) and a content analysis as in Bardin (2011). Both approaches have as a method of analysis the investigation of issues through operational categories: social inclusion, human development and professional training as a source of career building. Documents from MTur such as reports, regulations and policy papers enabled the gathering of evidences and other information to support the conclusions. All in all, this dissertation strongly suggests that it is required a combined effort among government, companies in the tourism sector and the educational system as a whole to turn professional training into an effective instrument to increase employment opportunities in the sector and to turn its workers capable to adjust to the ever changing labor market conditions and qualification demands.
\end{abstract}

Key words: 1. Public policies for qualification in Tourism 2. PRONATEC Tourism 3. Professional Training and Qualification in Tourism 4. Social Inclusion through Tourism 5. Human development. 


\section{LISTA DE ILUSTRAÇÕES}

\section{FIGURA}

Figura 1 - Nível de escolaridade dos empregados formais nas ACT's ............................... 38

Figura 2 - Sinergias entre trabalho e desenvolvimento ................................................ 43

Figura 3 - Políticas para potencializar o desenvolvimento humano pelo Trabalho ............... 46

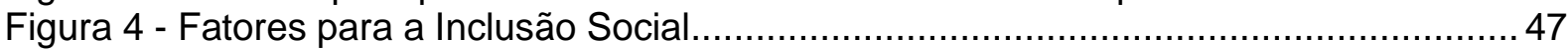

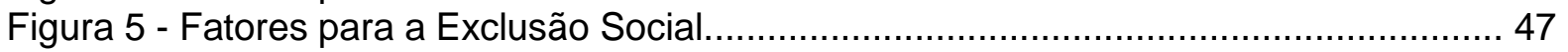

Figura 6 - Organização da Educação Brasileira (Lei 9.394/1996) .......................................59

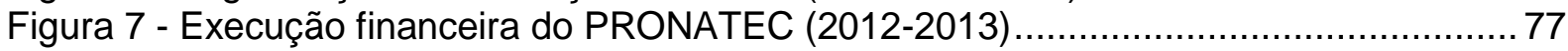

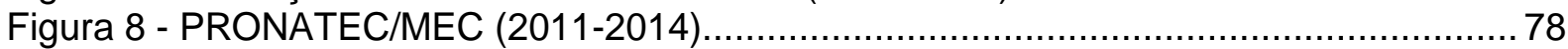

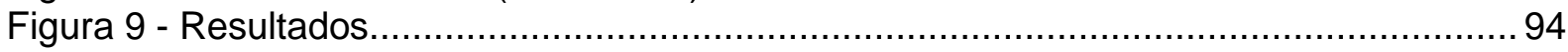

Figura 10 - Política Nacional de Qualificação em Turismo ............................................... 104

Figura 11 - Ilustração da estrutura da análise documental .............................................111

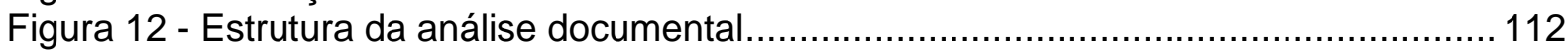

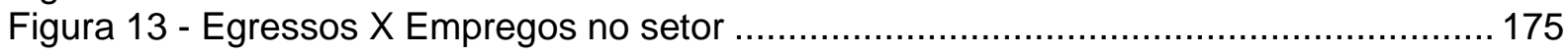

QUADRO

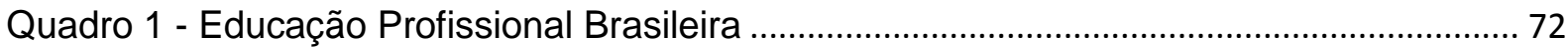

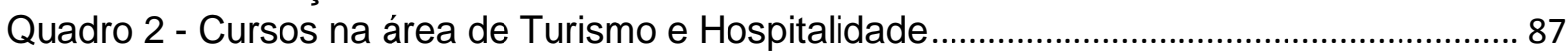

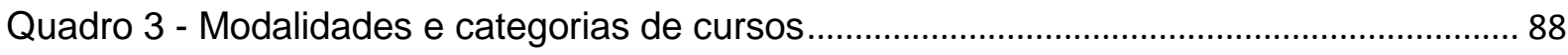

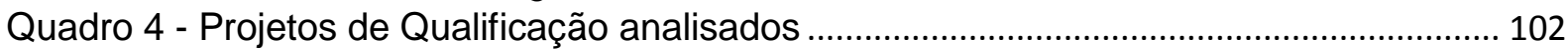

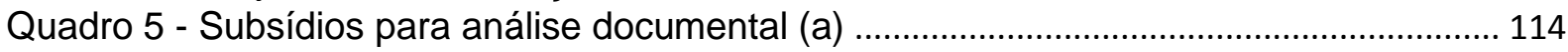

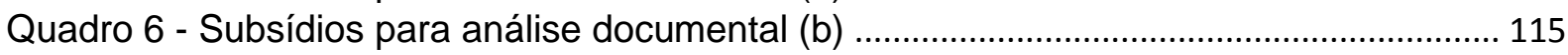

Quadro 7 - Sistematização da análise de conteúdo (modelo) ............................................... 119

Quadro 8 - Demanda e Oferta e Concluintes Cursos PRONATEC Turismo ........................... 138

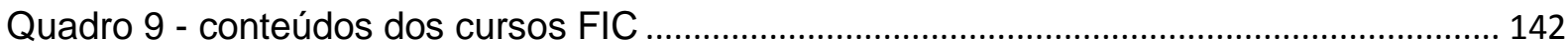

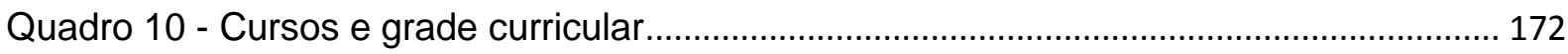

Quadro 11 - Boas práticas para o desenvolvimento humano pelo Turismo ............................ 177

ESQUEMA

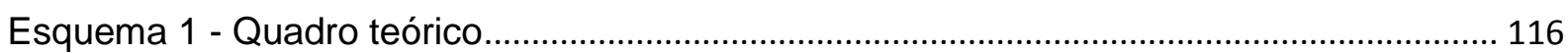

Esquema 2 - Fatores para a Inclusão Social ..................................................................... 171 


\section{LISTA DE SIGLAS}

ABRASEL: Associação Brasileira de Bares e Restaurantes

ABIH: Associação Brasileira da Indústria de Hotéis

ABETA: Associação Brasileira das Empresas de Ecoturismo e Turismo de Aventura

ABNT: Associação Brasileira de Normas Técnicas

BRAZTOA: Associação Brasileira das Operadoras de Turismo.

ACT's: Atividades Características do Turismo

CBO: Classificação Brasileira de Ocupações

CNAE: Classificação Nacional de Atividades Econômicas

CEFETs: Centros Federais de Educação Tecnológica

CODEFAT: Conselho Deliberativo do Fundo de Amparo ao Trabalhador

DNQT's: Diretrizes Nacionais para Qualificação em Turismo

EPCT: Expansão da rede federal de educação profissional científica

e tecnológica

FAT: Fundo de amparo ao Trabalhador

FIC: Formação Inicial e Continuada

FIFA: Federação Internacional de Futebol

IBGE: Instituto Brasileiro de Geografia e Estatística

IES: Instituições de Ensino Superior

IFRJ: Instituto Federal de Educação, Ciência e Tecnologia do Rio de Janeiro

$\mathrm{IH}$ : Instituto de Hospitalidade

IPEA: Instituto de Pesquisa Econômica Aplicada

ISIC: International Standard Industrial Classification

INVTUR: Inventário da Oferta Turística

LDB: Lei de Diretrizes e Bases da Educação Nacional

MEC: Ministério da Educação

MDS: Mistério de Desenvolvimento Social

MDH: Materialismo Histórico Dialético

MTE: Ministério do Trabalho e Emprego

MTur: Ministério do Turismo

NBR: Normas Brasileiras

OIT: Organização Internacional do Trabalho

PLANFOR: Plano Nacional de Formação do Trabalhador

PIB: Produto Interno Bruto

PIPMO: Programa Intensivo de Preparação de Mão-de-obra

PNE: Plano Nacional de Educação

PNQ: Plano Nacional de Qualificação

PNMT: Programa Nacional de Municipalização Turismo

PNT: Plano Nacional do Turismo

PNUD: Programa das Nações Unidas

PROEP: Programa de Expansão da Educação Profissional

PRONATEC: Programa Nacional de Acesso ao Ensino Técnico e Emprego

SEBRAE: Serviço Brasileiro de Apoio à Pequena e Média Empresa

SENAC: Serviço Nacional de Aprendizagem Comercial

SENAI: Serviço Nacional de Aprendizagem Industrial 
SENAR: Serviço Nacional de Aprendizagem Rural

SENAT: Serviço Nacional de Aprendizagem e Transporte

SESCOOP: Serviço Nacional de Apoio ao Cooperativismo

SESI: Serviço Social da Indústria

SETEC: Secretaria de Educação Profissional e Tecnológica

SIMT: Sistema Integrado de Informações sobre o Mercado de Trabalho no Setor de

Turismo

SIPROTUR: Sistema de Acompanhamento do PRONATEC Turismo

SISTEC: Sistema Nacional de Informações da Educação Profissional e Tecnológica RIOTUR: Empresa de Turismo do Rio de Janeiro

UNESCO: Organização das Nações Unidas para a Educação, a Ciência e a Cultura 


\section{Sumário}

INTRODUÇÃO

CAPÍTULO 1: POLÍTICA, EDUCAÇÃO E TRABALHO NO CAMPO PROFISSIONAL DO TURISMO

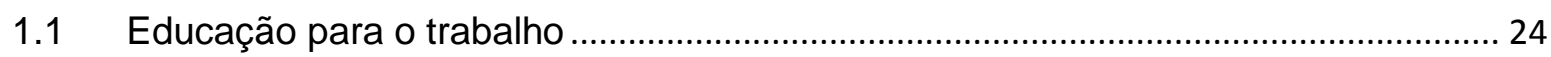

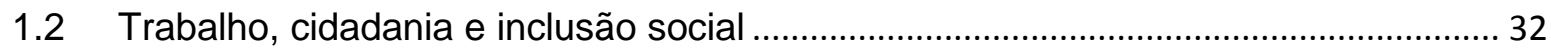

1.3 Políticas públicas, educação, formação profissional ................................................... 53

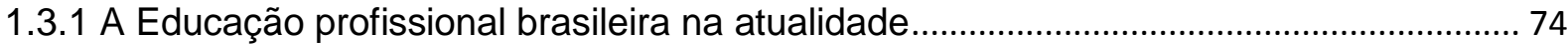

1.3.2 ATUAL POLÍTICA DE QUALIFICAÇÃO PROFISSIONAL EM TURISMO ............................................ 84

CAPÍTULO 2: A MATERIALIDADE HISTÓRICA DA POLÍTICA DE EDUCAÇÃO PROFISSIONAL EM TURISMO NO BRASIL

2.1 Caminhos metodológicos: processo de construção do Objeto de Pesquisa ................ 107

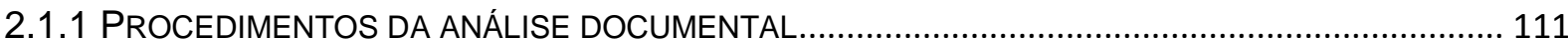

2.2 Concepção teórico metodológica: o materialismo histórico dialético .............................. 121

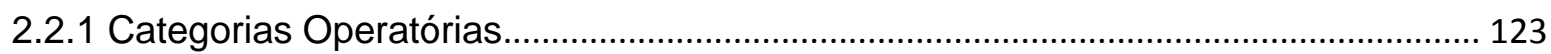

CAPÍTULO 3: A INCLUSÃO SOCIAL DE JOVENS E ADULTOS PELA EDUCAÇÃO PROFISSIONAL EM TURISMO E HOSPITALIDADE

3.1 O PRONATEC Turismo limites e possibilidades como política de inclusão social pela qualificação em turismo e hospitalidade

3.2 A política de qualificação profissional do Ministério do Turismo: equívocos e acertos de sua trajetória como ação propositiva de inclusão social ...................................................... 183

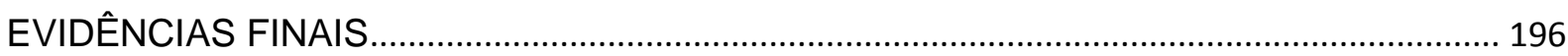

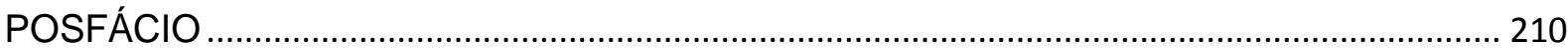

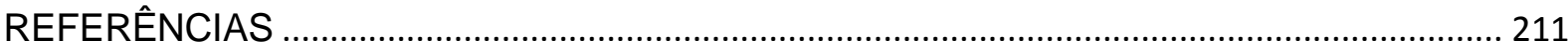

ANEXO A - CURSOS PRONATEC COPA (vigente até 2012) …...................................... 218

ANEXO B - CURSOS- PRONATEC TURISMO CIDADÃO ................................................. 220

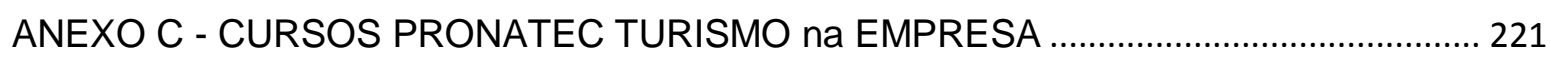

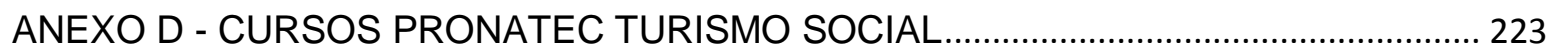

ANEXO E - CURSOS PRONATEC DESENVOLVIMENTO LOCAL ................................... 224

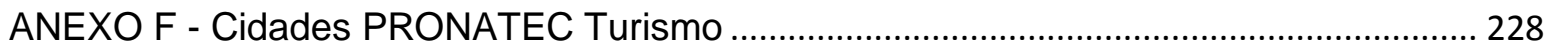

ANEXO G - INSTITUIÇÕES EXECUTANTES DO PRONATEC (cidades sedes) ............. 232

APÊNDICE A - Análise de conteúdo: Categoria Inclusão social e Categoria Desenvolvimento Humano/Cidadania

APÊNDICE B - Categoria Educação profissional possibilitadora da construção de

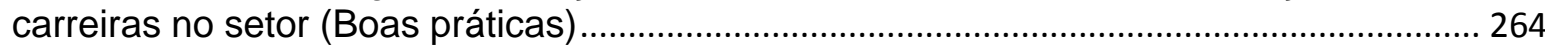

APÊNDICE C - Quantidade de egressos PRONATEC entrevistados (escolaridade) ...... 265

APÊNDICE D - Correlação cursos PRONATEC turismo x Normas ..................................... 266 



\section{INTRODUÇÃO}

A formação e qualificação profissional insere um forte elemento ao se considerar o desenvolvimento humanizador pela inclusão social de jovens e adultos pelo turismo.

Os chamados impactos positivos do turismo, principalmente os econômicos, têm sido referenciados por muitos programas de governo, que buscam maximizar as potencialidades do País, aumentar a competitividade e a qualidade dos serviços e produtos turísticos para promover o desenvolvimento do setor, entretanto as concepções e ações não contemplam o Turismo em sua complexidade. Ao reduzir e reproduzir, pelas políticas de qualificação, sua adequação aos interesses do capital, e do mercado internacional.

Desconhecem ou, ideologicamente negam que o turismo se constitui de uma prática social essencialmente humana, feito de relações sociais e culturais que precisam ser criativamente fomentadas para propiciar o efetivo desenvolvimento endógeno das localidades.

$\mathrm{Na}$ contramão alguns pesquisadores tem buscado romper essa visão mercantilista e alçado novas discussões, sobretudo a respeito da valorização do sujeito: turistas, residentes e trabalhadores. Neste contexto, a formação e qualificação profissional insere um forte elemento ao se considerar o desenvolvimento humanizador com a inclusão social de jovens e adultos pelo turismo.

A inclusão social esta relaciona à busca da estabilidade social por meio da cidadania social, que vislumbra a igualdade de direitos entre todos os cidadãos. A cidadania social preocupa-se com o bem-estar das pessoas enquanto cidadãos. (Sheppard, 2006).

Entre os benefícios auferidos pelo turismo a geração de empregos é um dos mais almejados. Para galgar as vantagens de fomentar e priorizar o turismo muitos governos e empresas têm investido no setor, mas sem resultados mais efetivos. Entre outras barreiras, a falta de trabalhadores qualificados é um elemento desfavorável para atingir a competitividade de seus negócios e o crescimento econômico das localidades. 
A qualificação dos integrantes do sistema de turismo no País ainda representa um grande desafio diante dos inúmeros obstáculos que se constatam: ausência de uma política consistente para o desenvolvimento das pessoas (formação emancipatória e cidadã); inadequação das grades curriculares diante das habilidades e competências necessárias para atuação; despreparo de formadores para compreensão do turismo como um fenômeno social; falta de formação especializada para os cargos de nível operacional, técnico e superior nos setores privado e público (profissionais, empresários e gestores públicos) atrelados ao descompasso da educação profissional com a educação básica, e a educação superior.

Em referência aos desafios que acompanham o turismo, juntamente com a crescente demanda por serviços especializados, conectados as novas tecnologias e aos anseios da sociedade por empregos dignos e inclusão social, posiciona-se o setor público, em especial o Ministério do Turismo (MTur) que, desde a sua criação, em 2003, propõem e atua com ações de qualificação.

Nos últimos anos (2012-2016), o MTur buscou incluir novas ações de qualificação, entre essas destacam-se: 1a) A sua atuação por meio do Programa Nacional de Acesso ao Ensino Técnico e Emprego (PRONATEC), associado ao setor do turismo; $2^{\mathrm{a}}$ ) A iniciativa para a elaboração das Diretrizes Nacionais para Qualificação em Turismo, a partir de investigação sobre as ações de qualificação fomentadas e com vistas à estruturação de uma política nacional de qualificação para o setor. Essa última na perspectiva de "estruturar de forma assertiva" o papel do ente público no auxílio ao desenvolvimento emancipador poderá, segundo aquele Ministério, reforçar o aspecto da inclusão social pelo turismo, ao valorizar os sujeitos envolvidos.

A primeira ação destacada visou atender as metas do Plano Nacional do Turismo 2013/2016 direcionadas à qualificação profissional para melhoria da qualidade dos serviços a ser ofertado aos turistas (em especial visando os megaeventos). O MTur, com o objetivo de elevar a competitividade do país como destino turístico, instituiu em parceria com o Ministério da Educação o PRONATEC Turismo com critérios e diretrizes para alcançar a melhoria da qualidade dos serviços ofertados aos turistas nas cidades sede da Copa do Mundo, seus entornos 
e em destinos turísticos consolidados nacional e internacionalmente, objeto desta dissertação.

Como resultado do estudo das Diretrizes foi evidenciado que uma política direcionada à qualificação deve visar resultados finalísticos e não simplesmente intermediários, que objetivem conferir serviços de qualidade aos turistas e melhores condições de trabalho aos trabalhadores. (MTur, 2015).

O que se verifica a partir da constatação acima é que para além do crescimento do setor vislumbrado no aumento da competitividade dos destinos atrelado ao aumento das receitas, do PIB, entre outros, a gestão pública do turismo deve ampliar o seu olhar e atuação, ao agregar a formação profissional para que contribua para o desenvolvimento humano e social das comunidades permitindo sua inclusão social.

Esta pesquisa buscou pela intepretação materialista histórico dialética da análise de conteúdo e da análise documental desvelar o processo de implementação da Política Pública de Qualificação em Turismo e Hospitalidade, pelo Programa PRONATEC Turismo, os impactos sociais na inclusão de jovens e adultos no mercado de trabalho do setor, e, sua contribuição para o desenvolvimento humano pelo Turismo.

Esta pesquisa buscou pela intepretação materialista histórico dialética da análise de conteúdo e da análise documental desvelar o processo de implementação da Política Pública de Qualificação em Turismo e Hospitalidade, pelo Programa PRONATEC Turismo, os impactos sociais na inclusão de jovens e adultos no mercado de trabalho do setor, e, sua contribuição para o desenvolvimento humano pelo Turismo.

Diante do contexto nacional das Políticas Públicas de qualificação lança-se a seguinte problematização: o Programa de Qualificação Profissional PRONATEC Turismo foi possibilitador da inclusão social de seus egressos no setor de turismo e hospitalidade?

Para encaminhar a reflexão sobre o problema de pesquisa tem-se como objetivo geral analisar a inclusão social de jovens e adultos no mercado de trabalho formal de turismo e hospitalidade pelo PRONATEC Turismo. 
Para se alcançar o objetivo geral definido na pesquisa, delinearam-se os seguintes objetivos específicos:

- Identificar a relação do Programa PRONATEC Turismo, no período de 2012-2015, em relação às Atividades Características do Turismo (ACTs) e cursos de profissionalização correlatos.

- Analisar se as ações de qualificação pelo PRONATEC Turismo induziram o aumento de empregabilidade de jovens e adultos nos anos 2014-2015 no setor de turismo e hospitalidade.

- Identificar a correlação entre as tipologias de cursos ofertados pelo PRONATEC Turismo às necessidades de demanda de trabalhadores das cidades sedes.

- Verificar se o PRONATEC Turismo possibilitou a construção de carreiras profissionais aos seus egressos no setor de turismo e hospitalidade.

- Analisar se a formação profissional do PRONATEC Turismo foi possibilitadora do desenvolvimento humano dos seus egressos e consequente inclusão social.

Por se tratar de uma análise dialética essa dissertação está estruturada em ter capítulos representando a tese, capítulo 1, a antítese, capitulo 2, e a síntese capitulo 3 e evidências finais.

A tese inicial desta pesquisa consiste da percepção, na prática, de que a política pública de educação profissional em turismo, implementada pelo PRONATEC Turismo, não possibilitou a inclusão social dos egressos das ações de qualificação executadas, pelo entendimento de que essas ações não foram concebidas para atender as demandas e necessidades dos trabalhadores do setor. A visão predominante para a educação profissional continua atrelada ao desenvolvimento/crescimento econômico e não a transformação efetiva dos sujeitos pela educação.

A antítese se constitui de uma inferência de que a política pública de educação profissional em turismo, implementada pelo PRONATEC Turismo, pode ser possibilitadora da inclusão social dos egressos dos cursos de qualificação profissional, processo de desconstrução sobre o que está sendo dito em resumo: 
qualificação igual empregabilidade, só possível pelo novo olhar dialético sobre a realidade estudada, presente no segundo capítulo.

A síntese buscou a mediação entre as contradições encontradas no processo histórico estabelecido pelo Programa de Qualificação Profissional PRONATEC Turismo e seus limites e possibilidades como instrumento de uma política pública para a inclusão social de seus egressos, já que o mesmo programa tem continuidade como modalidade de formação profissional no país, reconstrução a partir dos achados, presente no terceiro capítulo e evidências finais.

O primeiro capítulo versa sobre o referencial teórico relacionado à pesquisa: educação para o trabalho, trabalho, cidadania, inclusão social, políticas públicas, educação emancipatória, libertadora e cidadã, educação problematizadora, formação profissional, tecendo o que comumente está colocado sobre o tema (tese), tendo em vista que se optou por uma concepção materialista histórico dialética na reconstrução do problema e evidências a ser abordado, por entender o turismo como uma prática social histórica portadora de contradições nem sempre aparentes.

$\mathrm{Na}$ discussão teórica sobre educação/profissional para o trabalho referenciouse a: Kuenzer (1991), Saviani (1983) PNUD (2015), Sarup (1978), Casali (1997), Morin (2001), Freire (1996), Frigotto (2001), Saul; Freitas (2007), Ivo et. al. (2013) e LDB (1996). Para a concepção de trabalho utilizou-se: Martoni (2014), Casali (1997), Ivo (2013), Frigotto (2001), Pochmann (2004), Coutrot (2000), Ipea (2011; 2014), MTur (2015); Turismo: Moesch $(2001,2015)$. Na sequencia apresenta-se 0 desenvolvimento humano, que perpassa pela cidadania por: Sachs, (2008), Ivo (2013), Adorno (1995), Gastal \& Moesch (2007), Demo (1992, 1994, 1995 e 2006), Santos (2000), Silva (2000) e Mata (1997), PNUD (2015), UNESCO (1998), Gomes; Pinheiros (2010), Favero; Casagranda et.al.(2012). Em políticas públicas e políticas de educação profissional utilizou-se: Arendt (2001), Heidemann; Salm (2014), Demo (1991; 1981), Gross (1971), Bustelo (1982), Kaplan (1971), Rodrigues (2010), Parente (2010), LDB (1996), PNE (2014), CF (1937), Histórico da educação profissional: Saul; Freitas (2007), Castioni (2010), Canali (2014), Fonseca (1961), MEC (2009, 2011, 2014, 2016), MTE (2001), Jorge (2009), Saul; Freitas (2007), Ivo et. al. (2013), Ipea (2011; 2015), Alves; Viera (1995). Na concepção de educação libertadora e emancipatória: Freire (1977; 1996), Adorno (1995), Morin (2001; 2004), 
Delors (1998), Saviani (1983), Frigotto (2001), Carvalho (2003), Castioni (2010), Saul \& Freitas (2007). Em inclusão social: Sheppard (2006), Kunzer, Sachs (2008), Irving at. al. (2015), Bergonsi \& Lacerda (2007), Gentili \& Frigotto (2000).

Ao longo deste estudo percorreu-se a trajetória das Políticas Públicas de educação profissional implementadas no País no limiar e início do século XXI até a atualidade (PLANFOR, PNQ, PRONATEC) que reforçam esta análise.

O segundo capítulo apresenta o caminho metodológico adotado bem como os instrumentos metodológicos utilizados para analisar o problema da pesquisa e responder as questões. Utilizou-se do Materialismo Histórico Dialético como método de abordagem, por permitir a interpretação da realidade, a qual se estabelece na práxis (teoria e prática), comportando resgatar o processo histórico da construção dessa política por meio da interpretação dos fatos que se apresentam carregado de contradições e da objetividade/subjetividade inerentes aos processos sociais.

Com objetivo de evidenciar elementos que respondam ao problema de pesquisa e desvelar o processo de implementação da política pública de qualificação profissional (PRONATEC Turismo) no período de 2011a 2015, utilizou-se da metodologia de análise documental a partir de Cellard (2008). O estudo foi realizado a partir do entendimento de duas articulações institucionais responsáveis pela qualificação dos cidadãos no Brasil, ou seja, as políticas de qualificação do MTur e o Ministério da Educação.

Os documentos selecionados para análise documental foram: Plano Nacional da Educação (2014) Lei de Diretrizes e Bases para Educação Nacional (1996); Centenário da Rede Federal de Educação Profissional e Tecnológica (2009); Lei oo 12.513 (2011); Guia PRONATEC de cursos FIC (2012); Catálogo Nacional dos Cursos Técnicos (2015); Lei no 11.171 (2008); Plano Nacional do Turismo (diretrizes metas e programas 2003-2007); Plano Nacional do Turismo (uma viagem de inclusão, 2007- 2010); Plano Nacional do Turismo (o turismo fazendo muito mais pelo Brasil, 2013-2016); Índice de Competitividade do Turismo Nacional. Relatório Brasil (2013); Relatório de Análise Documental Qualificação em Turismo (2014); Esboço do Documento de Referência para a Formulação da Política Nacional de Qualificação em Turismo (2016); Pesquisa Avaliativa dos Arranjos Territoriais Possibilitadores da Qualificação em Turismo (2016); Diretrizes Nacionais de 
Qualificação em Turismo (2015); Programa Nacional de Qualificação Profissional e Empresarial do Turismo (2006); e Plano Nacional de Qualificação do Trabalhador (PLANFOR) (2001); Plano Nacional de Qualificação (PNQ 2003-2007) (2003); e diferentes portarias e relatórios, resoluções que tratam da temática.

No terceiro capítulo delineia-se a síntese, por meio da apresentação das percepções finais desta pesquisa, utilizando-se do MHD, que permitiu pela análise de conteúdo identificar as contradições entre a teoria (discursos oficiais) e a prática (efetivação da política de qualificação profissional). Este método possibilitou dialogar com a realidade da implementação desta política do PRONATEC Turismo ao evidenciar as relações estabelecidas pelos sujeitos (setor público, privado, profissionais, egressos e empresários) na produção da materialidade da ação formativa. Possibilitando entender o "status quo" da qualificação e a sua relação com a inclusão social de jovens e adultos no mundo do trabalho formal do setor de turismo e hospitalidade.

O processo comportou uma pesquisa avaliativa sobre a relação teoria e prática, como desvelamento das contradições existentes utilizando-se como referência as categorias operatórias de análise a priori tais como: matéria, práxis, historicidade, teoria/prática, totalidade/fragmentação, contradição/mediação, objetividade/subjetividade, autonomia/dependência, criticidade/alienação e as categorias a posteriori: inclusão social, desenvolvimento humano e educação profissional possibilitadora de construção de carreiras, que foram determinantes para identificar se os cursos executados pelo Programa puderam ter resultados efetivos para o desenvolvimento integral do setor.

Finalmente apresentam-se as considerações "possíveis" da pesquisa, ponderando que o turismo envolve uma complexa combinação de interrelacionamentos (produção e serviços), que se integram a uma prática social com base cultural, herança histórica, meio ambiente diverso, cartografia natural, relações sociais de hospitalidade e troca de informações interculturais. A soma desta dinâmica sociocultural gera um fenômeno, recheado de objetividade/subjetividade (MOESCH, 2001), onde o lugar da qualificação profissional é pouco compreendido para o desenvolvimento humano possível. Mas, quando esses sujeitos, partícipes do 
processo educacional, são entendidos como individualidades históricas, portanto humanos, a qualificação amplia-se para educação emancipadora. 


\section{CAPÍtUlo 1: POLÍtica, EDUCAÇÃO E tRABALHO NO CAMPO PROFISSIONAL DO TURISMO}

Este capítulo objetiva apresentar e discutir os pressupostos norteadores das políticas públicas de educação profissional no Brasil, trazendo um referencial histórico de como esse processo ocorreu na prática, e, apontar os princípios essenciais para uma formação/qualificação integral dos sujeitos, ancorada na percepção de importantes pesquisadores dos temas educação para o trabalho, cidadania e inclusão social. Busca ainda conjecturar sobre como essas concepções teóricas estão refletidas nas práticas produzidas no turismo e na hospitalidade. Busca também refletir sobre a necessidade de inserir um processo de educação virtuoso, que possibilite o desenvolvimento humano pela formação profissional e pelo trabalho no setor, ou seja, o que está sendo dito sobre o tema, a tese.

Será pontuada a educação emancipatória e cidadã como condição fundamental ao desenvolvimento humano, que possibilite a autonomia dos sujeitos em situações no trabalho e na sociedade, apontando quais são os conhecimentos pertinentes para a educação do futuro. Expõe como as políticas públicas de educação profissional em turismo foram executadas no período compreendido entre 2011-2015 com foco na preparação do Brasil para a Copa do Mundo de Futebol FIFA 2014.

\subsection{EdUCAÇÃo PARA O TRABALHO}

$\mathrm{Na}$ educação voltada para o trabalho se verifica um sistema diferenciado e paralelo ao do ensino regular: preparação dos pobres, marginalizados para atuarem no sistema produtivo nas funções técnica de baixo e médio nível da hierarquia ocupacional (KUENZER, 1991). Para esse fim, foram criados os cursos de qualificação profissional no início do século $\mathrm{XX}$, em compasso ao desenvolvimento industrial. Desse modo, observa-se que a desarticulação entre a educação básica e a profissional é recorrente.

Corrobora com essa visão o que traz Saviani (1983, p. 31) "enquanto aparelho ideológico, a escola cumpre duas funções básicas: contribui para a formação da força de trabalho e para a inculcação da ideologia burguesa". 
Observa-se que a escola, em regra, busca uma preparação distinta da sociedade, na qual os mais pobres devem estar aptos para ocuparem cargos operacionais e técnicos e à classe dominante competem os cargos especializados, científicos e acadêmicos. Nesse contexto, é urgente romper essa visão ultrapassada, para se pensar numa educação básica de qualidade destinada a todos sem distinção, que Ihes permitam trilhar um caminho pessoal e profissional que possibilite o desenvolvimento humano pela educação e pelo trabalho.

$\mathrm{Na}$ atualidade, percebe-se que há um esforço de alinhar as modalidades de educação atendendo às premissas essenciais para à construção do conhecimento científico, técnico e operacional, pois, as competências e qualificações para o trabalho, no futuro, estarão cada vez mais avançadas, os empregos exigirão qualificações mais específicas e elevadas. A tecnologia demandará além das competências básicas, aptidões para a criatividade, a inovação e a solução de problemas. (PNUD, 2015).

Várias pesquisas e debates versam sobre as questões decorrentes da educação e do trabalho, em nível dos princípios gerais já se tem alguma clareza, no entanto, questões de fundo estão longe de ser resolvidas.

Faz-se necessária uma articulação entre essas duas premissas, a fim de se estruturar políticas públicas efetivas rumo a uma qualificação profissional de qualidade, uma vez que no Brasil a experiência tem demonstrado uma profissionalização superficial e estreita.

Saviani reforça essa ideia (1983 p. 35):

[...] a escola é determinada socialmente; a sociedade em que vivemos, fundada no modo de produção capitalista, é dividida em classes com interesses opostos; portanto, a escola sofre a determinação do conflito de interesses que caracteriza a sociedade. Considerando que a classe dominante não tem interesse na transformação histórica da escola (ela esta empenhada na preservação do seu domínio, portanto apenas acionará mecanismos de adaptação que evitem a transformação).

A formação profissional no local de trabalho ocorre, frequentemente, na forma de adestramento, no qual é oferecido um aprendizado objetivo, mas, fracassado em relação à construção da autonomia (ADORNO, 1995), atuando de forma imediatista, 
não permitindo uma formação emancipatória aos sujeitos, por meio de um horizonte mais ampliado de orientação.

Percebe-se desse modo que a educação está à mercê dos interesses do capitalismo e do mercado, o que dificulta muito a necessária transformação rumo a uma educação libertadora, que possibilite a inclusão social dos profissionais do setor de Turismo. Essa educação deve proporcionar um diálogo ativo voltado para a responsabilidade social e política que permita ao educando aprofundar na interpretação e resolução dos problemas. (FREIRE, 1977).

Acrescenta-se, ainda, que o trabalho baseado na produção em série é um fator de massificação, pela repetição de um mesmo ato, que resulta apenas uma parte da totalidade da obra, de que se desvincula, contribuindo para a domesticação do trabalhador.

No Turismo, essa prática é recorrente, pois ao se "treinar" os profissionais do setor, está-se promovendo uma capacitação em série, uma visão compartimentada do turismo, na qual cada profissional se torna apto para realizar tarefas específicas sem ter capacidade de entender o contexto no qual o Turismo se insere e suas dinâmicas. O capitalismo promove e estimula essa segmentação e fragmentação. (SARUP, 1978).

Um processo de educação virtuoso deve agregar além dos conteúdos técnicos e operacionais, conteúdos que possibilitem um conhecimento emancipatório (culturais, sociais, econômicos, entre outros), que permeiem uma educação problematizadora.

Quando os membros de uma classe trabalhadora ou camada social não dominam os conteúdos culturais, não conseguem defender os seus interesses, pois ficam desarmados contra os dominadores, que se servem desse conhecimento para legitimar e consolidar sua dominação. (SAVIANI, 1983).

Para Adorno (1995 p.170) "a exigência de uma emancipação parece ser evidente em uma democracia" levar as pessoas a aprender por intermédio da motivação é uma forma de desenvolvê-la. Este processo permite a libertação de um mundo determinado a dirigir nossas vidas.

O turismo como produto mundializado é capaz de gerar motivações que se transformam em passeios e viagens, mas como mercado de trabalho ele também 
pode proporcionar o aprendizado por meio das motivações que intrinsicamente estão associadas ao trabalho no setor, como por exemplo, conhecer novas pessoas e culturas diferentes, prazer por ajudar as pessoas e em prestar um serviço de qualidade, mas, será que essas motivações são as únicas necessárias para um melhor aprendizado no local de trabalho, ou ainda faltam motivações em termos de melhores condições de trabalho, reconhecimento profissional, carreiras e melhores salários.

Devido à transição da economia industrial para economias baseadas no conhecimento e na informação, entre essas o turismo, é necessário incluir novas dinâmicas ao modo de vida (pensar, trabalhar e aprender), incluindo novas aptidões, que de acordo com o PNUD (2015) são:

I. formas de pensar, que incluem criatividade, inovação, pensamento crítico, resolução de problemas, tomada de decisões e aprendizagem;

i. formas de trabalhar, que se referem à comunicação, colaboração e trabalho em equipe;

ii. ferramentas de trabalho baseadas nas novas tecnologias da informação, da comunicação e da interpretação, visando à construção de seu próprio conhecimento, incluindo competências para aprender e trabalhar através de redes sociais digitais; e,

iii. formas de viver no mundo, refletidas num sentido de cidadania global e local, numa visão em relação à vida e à progressão na carreira e num compromisso com a responsabilidade pessoal e social.

"A escolaridade, a flexibilidade, a adaptabilidade e as competências relacionadas com o trabalho são requisitos vitais para a garantia da subsistência dos trabalhadores". (PNUD, 2015 p. 188).

É no interior das relações sociais que o saber é produzido, produção coletiva dos homens em suas atividades diárias, práticas, ou seja, o trabalho se constitui em importante processo de elaboração do conhecimento. (MARX; ANGEL, 2004 apud KUNZER, 1991) ${ }^{1}$.

\footnotetext{
${ }^{1}$ MARX, Karl. ENGELS, Friedrich. Textos sobre Educação e Ensino. 4ª ed. São Paulo: Centauro, 2004. Biblioteca do Professor.
} 
Morin (2001) na definição dos setes saberes necessários à educação do futuro apresenta como essenciais:

1. conhecimento - o que é o conhecimento, como se produz; é uma tradução/reconstrução, ou seja, ele é válido quando se estimula a capacidade dos educandos em colocá-lo em prática no seu cotidiano;

2. princípios do conhecimento pertinente - ensinar não apenas a visão global e fundamental do mundo, mas, também, os conhecimentos parciais e locais; não basta ter uma visão fragmentada por disciplinas, é necessário identificar o vínculo entre as partes e a totalidade. Apreender o objeto em seu contexto, complexidade e conjunto;

3. ensinar a condição humana - a educação deve integrar aos processos educativos a formação física, psíquica, biológica, social, cultural e histórica do ser humano;

4. ensinar a identidade terrena - conhecer a realidade do mundo (processos ambientais, econômicos, ideológicos, sociais), problemas e ameaças ao planeta, buscando um entendimento comum da condição humana;

5. enfrentar as incertezas - deve-se considerar as incertezas na produção do conhecimento, pois nenhum conhecimento é absolutamente certo, imutável, e, ensinar princípios e estratégias que permitam enfrentar os imprevistos, o inesperado e as incertezas e modificar seu desenvolvimento em virtude das informações adquiridas ao longo do tempo;

6. ensinar a compreensão - a compreensão humana deve ser considerada em uma educação do futuro, visando compreender e respeitar as diferenças, para propiciar atitudes de tolerância e respeito com o outro;

7. ética do gênero humano - educação como ferramenta de cidadania, capaz de encaminhar os indivíduos rumo a uma sociedade democrática.

Para que os trabalhadores possam atingir esses saberes são urgentes medidas políticas específicas, que deverão incidir aos seguintes objetivos (PNUD, 2015):

- Conceber e implementar um sistema de aprendizagem preparado para o futuro, com elevada qualidade que busque ensinar aos alunos a construir seu próprio conhecimento. Deve-se buscar "uma mudança de paradigma de 
aprendizagem - que vá para além da meta do acesso universal ao ensino para chegar ao acesso e aprendizagem". (PNUD, 2015 p. 188).

- Buscar o aumento do acesso ao ensino superior, associado às exigências do mundo de trabalho e a uma formação emancipatória e cidadã.

- Atualizar e reorientar as competências, para que o trabalhador do futuro possa estar apto às mudanças do mundo do trabalho, à inserção em outra ocupação ou mercado, caso necessário.

- Disponibilizar recursos a programas de educação de adultos para a aprendizagem ao longo da vida ${ }^{2}$, para estágios de aprendizagem e programas de formação vocacionados para setores específicos, conjuntamente com programas de formação em contexto real de trabalho ${ }^{3}$, ajudam a preparar os jovens para a vida ativa e permitem futuras mudanças de carreira e deve-se dar especial atenção à formação e as oportunidades de trabalhos para as mulheres.

- Investir em uma formação empresarial inovadora, de modo a possibilitar reinventar as organizações e as empresas, quanto mais amplo e profundo o conjunto de ideias e indivíduos acessíveis, mais oportunidades existem para a inovação, e principalmente para alavancar a tecnologia e as competências humanas sempre em evolução.

- Adotar inovações complementares, de modo a facilitar e ampliar o acesso às ferramentas de trabalho.

- Desenvolver planos para os trabalhadores migrantes, que permitam inclui-los em programas destinados a trabalhadores sazonais em setores como a agricultura e o turismo ${ }^{4}$, para possibilitar à inclusão socioprodutiva.

\footnotetext{
2 "Os países do Norte da Europa são particularmente bem sucedidos na aprendizagem ao longo da vida, sendo que na Dinamarca, Finlândia, Países Baixos, Noruega e Suécia mais de $60 \%$ da população adulta participam na educação de adultos". (PNUD, 2015 p. 191).

3 "Esses programas podem ser organizados tanto pelos empregadores como pelos governos. São necessárias, também, políticas de incentivo à realização de ações de formação pelos empregadores, tais como créditos fiscais ou acesso preferencial a contratos públicos". (PNUD, 215 p. 191).

4 "Todos esses programas poderiam ser desenvolvidos no âmbito de acordos celebrados nos países de destino através de processos políticos baseados em discussões públicas, que equilibrem os diferentes interesses, prioridades e exigências locais, bem como em discussões que envolvam os países de origem, os empregadores e os sindicatos. Essencial em todos esses processos é aumentar a segurança, a proteção e os direitos dos trabalhadores migrantes". (PNUD, 215 p. 192).
} 
- Garantir os direitos dos trabalhadores para proporcionar proteção e segurança. Essa garantia é crucial para reforçar as relações positivas entre o trabalho e o desenvolvimento humano e reduzir as negativas.

\begin{abstract}
As relações positivas asseguram que os direitos $e$ regalias dos trabalhadores vão além da adequação salarial e incluam um ambiente onde os trabalhadores sejam mais produtivos e tenham maior segurança e capacitação. A redução das relações negativas passa pela garantia dos direitos e benefícios dos trabalhadores, bem como pela eliminação da exploração, dos abusos, dos ambientes de trabalho inseguros e da destruição da dignidade. (PNUD, 2015 p. 192).
\end{abstract}

- Oportunizar acesso aos trabalhos às pessoas com deficiências - reforçando suas capacidades. O turismo pode possibilitar a inclusão socioprodutiva dessas pessoas.

Portanto, a educação profissional constitui-se de uma eficaz estratégia na busca pelas mudanças necessárias. É pela formação das pessoas que são garantidas as condições de reflexão sobre o modo de pensar, agir e tomar decisões quanto aos princípios, pressupostos e atividades previstas e seu compromisso moral e ético com o trabalho exercido. Não se restringir a aquisição de saberes no sentido acadêmico, mas também incluir aquisição do saber-fazer, ou seja, habilidades profissionais somadas a um saber-ser ético e de comportamentos sociais solidários, unindo a formação à informação. (CASALI, 1997).

Essas necessidades são resultados das mudanças que nortearam o crescimento industrial nos últimos tempos, principalmente, a difusão da tecnologia e da informação, aceleradas pelo processo de globalização, repercutiram de forma significativa no turismo. As facilidades de acesso à informação e a elevação do poder aquisitivo de grande parte dos consumidores em seu tempo de lazer aumentaram o nível de exigência da qualidade dos serviços prestados no espaço turístico e da mesma forma a incorporação de novos profissionais devidamente preparados. Na prática, ainda é pouco perceptível à profissionalização das ocupações do setor, pois à formação profissional em Turismo carece de um processo formativo integral dos trabalhadores, ou seja, um processo virtuoso que articule a educação profissional com a educação básica, de modo a proporcionar o desenvolvimento humano dos trabalhadores do turismo e hospitalidade. 
Para Freire (1996) os empresários modernos aceitam, estimulam e até podem patrocinar o treino técnico do seu empregado, no entanto, recusam a formação, que envolve o saber técnico e científico indispensável e proporciona a sua autonomia no mundo. "Transformar a experiência educativa em puro treinamento técnico é amesquinhar o que há de fundamentalmente humano no exercício educativo: o seu caráter formador". (FREIRE, 1996 p. 37).

As formas de encaminhamento das aprendizagens na sociedade do conhecimento fundam-se a partir da inter-relação entre os sujeitos e o meio, o que exige novas didáticas de ensino que valorizem a resolução de problemas, buscando o equilíbrio entre a liberdade de criação e a autoridade do saber. A formação profissional deve ser concebida no seu sentido integrador o mais amplo possível conforme Casali (1997).

\begin{abstract}
A educação para o trabalho tem como tarefa essencial restituir ao homem a possibilidade de realizar suas capacidades e desenvolver-se através do trabalho, isto é, a possibilidade de conhecer, de apropriar-se, de transformar o processo de produção aproveitando as potencialidades do desenvolvimento técnico. (BRASIL, 1996b, p.33).
\end{abstract}

De acordo com Frigotto (2001) para se estabelecer um projeto de educação profissional centrada na perspectiva de emancipação da classe trabalhadora é necessário que o processo incida sobre cinco aspectos:

1. solidariedade e igualdade entre os seres humanos versus projetos advindos com a industrialização nos quais prevalecem a hegemonia do interesse dominante e do mercado em detrimento do interesse coletivo de uma sociedade;

2. educação básica (unitária, pública, gratuita e universal) de qualidade, formadora de sujeitos autônomos, protagonistas de cidadania ativa e articulada a um projeto de Estado democrático e a um projeto de desenvolvimento sustentável, na perspectiva de que essa educação proporcione a emancipação humana e uma melhor preparação técnica para o mundo do trabalho, acompanhando as revoluções científicas e tecnológicas;

3. promover uma formação técnico-profissional articulada ao desenvolvimento sustentável, porém sempre articulada à educação básica, à dimensão ético- 
política, à formação de sujeitos autônomos e construtores de processos sociais democráticos, solidários e igualitários;

4. não tomar a educação profissional como política focalizada na geração de emprego, tampouco como preventiva ao desemprego e como estratégia para a integração ao mundo globalizado. A política de educação profissional, antes de tudo, deve se pautar em um projeto alternativo de desenvolvimento humano;

5. articular as relações sociais de produção e as relações políticas, culturais e educativas.

Cabe indagar se a qualificação profissional em turismo colocada em prática nos últimos tempos e na atualidade tem permitido a emancipação dos trabalhadores do setor? Este trabalho pretende responder essas e outras questões expostas adiante.

\subsection{TRABALHO, CIDADANIA E INCLUSÃo SOCIAL}

O mundo do trabalho passa por transformações de todos os níveis; os desafios de reordenamento em escala mundial e a modernização tecnológica e gerencial alteram o perfil da oferta de emprego. Essa dinâmica atinge diretamente os trabalhadores, pois acarreta em graves consequências ao trabalho, como o desemprego e a exclusão social que esse processo ocasiona. (CASALI, 1997).

O trabalho é extensão da vida humana os sujeitos criam e recriam sua existência em função dele, processo no qual ocorre o intercâmbio entre o ser humano e a natureza. $O$ trabalho assume duas vertentes (necessidade e liberdade). A primeira está vinculada a ideia predominante do mercado e do capitalismo, na qual o labor é necessário para subsistência dos sujeitos e para manter ativa a economia de um país ou região. Enquanto que o trabalho como liberdade está conectado às possibilidades de escolha entre alternativas com o intuito de atender às necessidades humanas naturais (também chamadas de carências) e as historicamente criadas. (MARTONI, 2014).

O trabalho, como criador de valores de uso, como trabalho útil, é indispensável à existência do homem - quaisquer que sejam as formas de sociedade - é necessidade natural e tema de efetivar o intercambio material 
entre o homem e a natureza, e portanto, de manter a vida humana. (MARX, 1982, p. 50 apud FRIGOTTO, 2001, p.3).

O desenvolvimento de um país ou região está comumente atrelado ao crescimento econômico, à produção e à força de trabalho que alimenta esse processo; a preocupação com a pobreza e a desigualdade social é um "tema relativamente novo no pensamento econômico e na elaboração de políticas públicas". (IVO, 2013).

No Brasil, na década de 1990, acentuaram-se os níveis de desemprego, a precariedade, o sobretrabalho ${ }^{6}$ e a deterioração dos níveis de renda, especialmente entre as faixas etárias mais jovens. Houve uma deterioração das condições de funcionamento do mercado de trabalho, que ao invés de ser contida pela melhoria educacional (implementação do PLANFOR - 1996) ${ }^{7}$, contribuiu para o desperdício e 0 desgaste de habilidades educacionais em atividades precárias e de baixa qualidade.

A segmentação ocupacional é oriunda desse processo desfavorável do mercado de trabalho, que excluí os mais pobres dos empregos nos segmentos educacionais mais elevados e, em contrapartida os prepara para as funções operacionais e repetitivas. Ampliando consideravelmente o processo discriminatório no interior do mercado de trabalho, sobretudo entre jovens e adultos, raças e gênero (POCHMANN, 2004). Acrescenta, que:

[...] tal círculo vicioso impediu que a educação revelasse o seu potencial transformador das relações humanas e da agregação de valor à produção no Brasil. No contexto de emergência da sociedade do conhecimento, os requisitos educacionais do emprego ampliaram-se (POCHMANN, 2004, $p$. 384).

Com isso, o Brasil acabou por se afastar das oportunidades de assimilação das tendências positivas da sociedade do conhecimento, ao contrário, caracterizando como uma sociedade de baixos salários voltada à exportação de

\footnotetext{
${ }^{5}$ MARX, K.. O capital. 7. ed. São Paulo: Difel, 1982.

${ }^{6}$ Considera-se sobretrabalho as situações relativas aos ocupados com jornada de trabalho acima de 44 horas semanais, aos aposentados e pensionistas que se mantêm ativos no mercado de trabalho, aos trabalhadores com mais de uma ocupação e ao trabalho de pessoas abaixo de 16 anos de idade. ${ }^{7}$ Grifo nosso. O Plano Nacional de Qualificação do Trabalhador, implementado em todas as regiões do país a partir de 1996, sob a direção do Ministério do Trabalho e Emprego (MTE) e com recursos do Fundo de Amparo ao Trabalhador (FAT).
} 
bens primários (agronegócios) e ao consumo de serviços pessoais, demandados pela classe dominante. (POCHMANN, 2004).

A ideia de pleno emprego não é uma noção evidente, especialmente nos países do chamado Terceiro Mundo ${ }^{8}$, no caso do Brasil, o mercado de trabalho se caracteriza por um grau elevado de informalidade (em torno de 50\% dos trabalhadores não têm contrato de trabalho, consequentemente estão na informalidade ou trabalham por conta própria - ambulantes, produtores artesanais, engraxates etc.). Em contrapartida, os trabalhadores formais apesar de algumas garantias estipuladas em leis trabalhistas, também estão expostos as variáveis do mercado, persistindo as demissões e a alta rotatividade, tendo em vista as baixas perspectivas de crescimento profissional em muitas áreas. (COUTROT, 2000).

“Em pleno limiar da sociedade do conhecimento, o Brasil precisa abandonar a concepção conservadora e ultrapassada do trabalho como obrigação pela sobrevivência para reconstituir uma nova transição do sistema escolar para o mundo do trabalho". (POCHMANN, 2004 p. 397). Dessa forma, a perspectiva de uma educação continuada ao longo da vida, deve sair do papel para ser efetivada. Somente desse modo, será possível vislumbrar uma maior profissionalização do trabalho no País.

O mercado de trabalho em turismo e hospitalidade está intrinsicamente conectado ao crescimento do setor, que deriva do aumento da circulação de turistas associado à potencialidade dos negócios ligados à hospitalidade-produtiva, o que acaba demandando e fomentando uma estrutura turística, alavancando processos em que tanto a questão do ordenamento do espaço, via políticas públicas, como as condições em que trabalhadores são absorvidos em Atividades Características do Turismo (ACT's) são determinantes para a instalação de empreendimentos (MARTONI, 2014) e, consequentemente para a geração de emprego e renda e para os efeitos desse mercado sobre o trabalhador do setor.

\footnotetext{
${ }^{8}$ Consideram-se países de Terceiro Mundo os países que possuem economia subdesenvolvida ou em desenvolvimento, geralmente nações localizadas na América Latina, África e Ásia. A expressão foi criada a partir da observação que o economista francês Alfred Sauvy realizou acerca dos países do mundo, ele constatou que existia uma enorme disparidade política, econômica e social entre as nações, deixando muitas delas marginalizadas no cenário mundial.
} 
Estudos elaborados pelo Instituto de Pesquisa Econômica Aplicada (IPEA) desde $2003^{9}$ a respeito do mercado de trabalho e do desempenho do setor de turismo, bem como do seu impacto econômico e social nos níveis nacional, estadual e regional, especificamente em relação ao número de empregos formais (participação relativa de cada atividade no total de empregos formais e a evolução do emprego nessas atividades no período de dezembro de 2002 a dezembro de 2011) nas ACTs ${ }^{10}$ : alojamento, agência de viagem, transportes, aluguel de transportes, auxiliar de transportes, alimentação e cultura e lazer, apontam que em 2011 as ACT's eram responsáveis por aproximadamente $2,077^{11}$ milhões de ocupações no Brasil. Entre estas, cerca de 947 mil (47\%) eram empregos formais e 1.131, informais (53\% do total). (IPEA, 2011 e 2014).

Em referência a esses dados, pode-se constatar a enorme informalidade no setor o que dificulta, ainda mais, a inserção digna dos profissionais de modo a estabelecer um efetivo desenvolvimento humano pelo trabalho, pois, nessa situação os trabalhadores não possuem as garantias mínimas para desempenharem um trabalho virtuoso que Ihes possibilitem um desenvolvimento emancipatório pelo trabalho em turismo.

Além da informalidade, o setor, também, responde pela geração de empregos temporários, devido à sazonalidade inerente aos destinos turísticos, mesmos os destinos consolidados apresentam tais características, já que o turismo se dá principalmente nos períodos de férias, tanto escolares, como de trabalho. É certo, que esse fator, poderia ser contornado por políticas públicas eficientes nos municípios turísticos, que possibilitassem ações para alavancar o turismo por meio da oferta de produtos e serviços com autovalor agregado para públicos diversos em

\footnotetext{
${ }^{9}$ O IPEA, com o apoio do Ministério do Turismo (MTur), estruturou o Sistema Integrado de Informações sobre o Mercado de Trabalho no Setor de Turismo (SIMT), que visa oferecer ao governo e à sociedade informações obtidas a partir de fontes secundárias e de pesquisas realizadas pelo Ipea sobre a ocupação nas atividades características do turismo (ACTs), com o objetivo de auxiliar o MTur com informações para subsidiar a elaboração e o monitoramento de suas políticas.

${ }^{10}$ As ACT's são um conjunto de atividades econômicas que contemplam a maior parte dos gastos dos turistas.

${ }^{11}$ Esse número equivale ao total de ocupados no setor, sem a aplicação do coeficiente de atendimento ao turista, metodologia do IPEA que foi aplicada ao total de empregos por ACT's, em um esforço de considerar apenas os profissionais que atendem aos turistas, cujo valor baixa para 1,3 milhões de pessoas empregadas no setor. No entanto como o recorte territorial deste trabalho são os municípios sedes da Copa do Mundo FIFA 2014, é preferível trabalhar com o total sem o coeficiente já que os dados com o coeficiente só alcançam até o nível estadual.
} 
períodos distintos. Deste modo, seria possível contornar essa situação e inserir esses profissionais em empregos formais no setor.

Outros fatores negativos associados ao mercado de trabalho em turismo dizem respeito aos salários comumente praticados no setor, a alta rotatividade e a baixa escolaridade dos trabalhadores que segundo Martoni (2014), a falta de organização política, se revela em trabalhadores submissos e dóceis, e, em ocupações pouco dispendiosas:

\begin{abstract}
No caso do turismo, as vantagens de localização são representadas pela dotação em riquezas naturais (sol, mar, montanhas etc.), bem como pelo [...] patrimônio cultural e histórico de um país [...]. Boa parte das atividades ligadas [ao turismo] são intensivas em mão-de-obra; é por isso que as multinacionais do setor obtêm consideráveis vantagens por sua localização em países que combinem atrações naturais com mão-de-obra barata. (CHESNAIS, 1996, p.203 apud MARTONI, 2014, p. 160). ${ }^{12}$
\end{abstract}

Segundo o IPEA (2014) o perfil médio dos ocupados formais do turismo no Brasil está representado pelo sexo masculino (55\%), na faixa etária de 25 a 49 anos (67\%), possuindo segundo grau ou nível superior incompleto $(60 \%)$, está há aproximadamente menos de doze meses no emprego (43\%), recebe até dois salários mínimos (67\%), trabalha em estabelecimentos que têm entre dez e 99 empregados (52\%), portanto em pequenas empresas, de acordo com a classificação por número de empregados do SEBRAE, e trabalha mais de quarenta horas por semana (89\%). Apesar de haver mais homens do que mulheres no mercado de trabalho do turismo, representando $45 \%$ dos empregos formais, esse índice é alto se comparado com a economia em geral $38 \%$.

Confirmam-se com os dados do IPEA os baixos salários pagos no setor, onde quase 70 dos trabalhadores recebem até dois salários mínimos, corrobora com essa informação o que aponta Martoni (2014 p. 175) "há uma organização da classe empresarial com vistas a nivelar o preço da força de trabalho abaixo do seu valor". Assim, segue o mercado, nivelando por baixo os trabalhadores do setor, preferindo a informalidade e os contratos temporários, que representam menos custos. $\mathrm{Na}$ contramão sabe-se que o turismo carece de pessoal qualificado e de

${ }^{12}$ CHESNAIS, François. A mundialização do capital. Tradução de Silvana Finzi Foá. São Paulo: Xamã, 1996. 
profissionalismo, para agregar valor junto aos produtos e serviços, mas, para isso é necessária uma mudança de mentalidade quer do setor público, por meio de políticas inclusivas destinadas aos trabalhadores do setor, quer do privado pela valorização e oferecimento de melhores condições de trabalho.

Seguindo com a análise do IPEA o forte predomínio de homens no setor está relacionado às atividades relativas a transporte, que representam cerca de $30 \%$ dos empregos existentes no turismo do Brasil. Além disso, a ACT alimentação, que representa $40 \%$ dos empregos, apesar de ter mão de obra predominantemente feminina, tem $47 \%$ de homens entre seus empregados. No núcleo do turismo ${ }^{13}$, há predominância da mão de obra feminina (54\%), devido às atividades de alojamento e agência de viagem, que possuem 58\% e 57\% de mulheres, respectivamente, e, juntas, representam $82 \%$ dos empregos do núcleo do turismo no Brasil. (IPEA, 2014).

Desses dados pode-se inferir que o setor possui forte demanda para empregar mulheres, em relação à economia geral, está representado por pessoas em idade adulta (no entanto apresenta oportunidades para empregar jovens), mais da metade dos empregados possui nível médio de escolaridade, no entanto, há uma gama de profissionais com ensino fundamental incompleto e menos de $10 \%$ com ensino superior, conforme aponta a figura 1. A remuneração média é baixa e a jornada de trabalho exige dedicação exclusiva do trabalhador. Existe uma baixa retenção dos profissionais, o que provavelmente deva-se à falta de prospecção de futuro para os trabalhadores (qualificação, reconhecimento, remuneração, planos de carreiras, entre outros).

De acordo com o panorama apresentado percebe-se estreita relação entre a baixa remuneração, o nível de escolaridade dos profissionais do setor, e a permanência no emprego, levando-se a inferir que um processo de formação/qualificação virtuoso pode se constituir de possibilidade concreta para proporcionar a inclusão social e ampliar a qualidade de vida desses profissionais.

\footnotetext{
${ }^{13}$ São as ACTs mais fortemente vinculadas ao turismo: alojamento, agências de viagem e transporte aéreo e para a economia como um todo. São apresentados também dados relativos a ocupações mais frequentes em atividades que constituem o núcleo do turismo e da atividade alimentação, como garçom, camareiro e emissor de passagens (IPEA, 2014).
} 
Figura 1 - Nível de escolaridade dos empregados formais nas ACT's

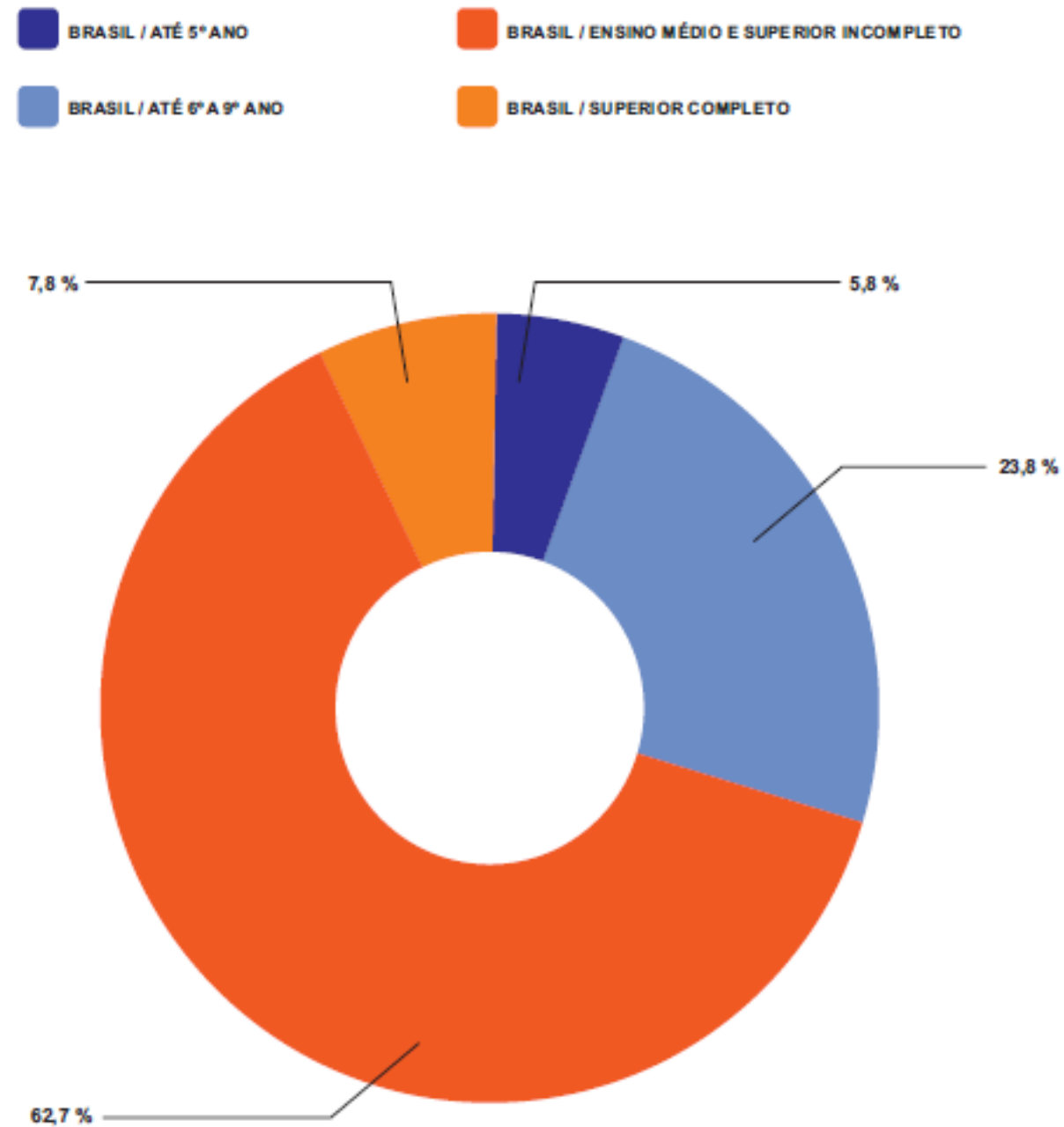

Fonte: Elaborada pela autora com base no SIMT/IPEA (2016)

Infere-se, ainda, que o setor de turismo apesar de ter um enorme potencial para empregar jovens, por apresentar oportunidade ao primeiro emprego, não está sendo atrativo para essa parcela da população, e com isso corre o risco de que esses jovens ao permanecerem desempregados por longos períodos de tempo comecem a perder as suas competências e a autoestima, o que reduz o seu potencial de trabalho futuro. Esse fator tende a reduzir o potencial econômico dos países, devido à subutilização das capacidades dos indivíduos. Além disso, diminui 
a coesão social e tende a aumentar a criminalidade, a violência e os distúrbios sociais, afetando comunidades inteiras. (PNUD, 2015).

O setor de turismo que é essencialmente de serviços, preferencialmente com potencial valor agregado, ou seja, não basta prestar um serviço de qualidade, mas é necessário fazer a diferença, necessita cada vez mais de trabalhadores com escolarização básica, técnica e superior, agregada à formação profissional, ou formação para o trabalho, bem como profissionais e técnicos altamente qualificados. Em um mercado global extremamente dinâmico em que os produtos e processos mudam rapidamente, é fundamental uma educação básica de qualidade e uma aprendizagem contínua, que se processe de forma rápida e eficiente.

\footnotetext{
Dispor de um conjunto de capacidades básicas promove o sucesso em muitos aspetos da vida. As competências cognitivas e não cognitivas (como a consciencialização, a autorregulação da aprendizagem, a motivação e a visão de futuro) interagem de forma dinâmica e moldam a evolução das capacidades subsequentes. (PNUD, 2015, p. 117).
}

Para se pensar na política para o turismo, especificamente no que tange à qualificação e formação no setor é preciso compreender que o turismo envolve o deslocamento dos sujeitos do seu espaço habitual e de sua rotina, por diferentes motivações: saúde, lazer, profissionais, educacionais ou mesmo para se recompor e revigorar-se para voltar à rotina, independente da motivação, esse deslocamento produz necessidade de organização de produtos e serviços turísticos que contenham na sua composição uma estrutura que atenda e proporcione hospitalidade/acolhimento (GASTAL e MOESCH, 2007) fatores inerentes à qualificação dos destinos e aos profissional que atuam no setor. Deste modo é inegável o papel propulsor de políticas públicas destinadas à formação/qualificação para o desenvolvimento efetivo do turismo, ou seja, em termos de competitividade do setor e em termos de desenvolvimento humano e social dos trabalhadores.

As políticas públicas de formação/qualificação em turismo devem propor ações que visem o desenvolvimento dos sujeitos, que incorporem uma visão multidisciplinar e multicultural, tão necessária ao desenvolvimento humano e a inclusão social, por meio do emprego, do crescimento profissional e do acesso e avanço educacional. 
Por outro lado, é notável que as demandas por serviços se tornem mais exigentes, isso já se verifica no setor de turismo, conforme aponta a prospecção de futuro (2030) do estudo para elaboração das Diretrizes Nacionais para Qualificação em Turismo. (BRASIL, 2015a):

1. Dirigentes, gerentes, planejadores e assessores de alto nível, com compreensão sistêmica do turismo, visão estratégica dos negócios e entendimento das dimensões e articulações da sustentabilidade, com capacidade de antecipação das tendências do mercado e da introdução de novas tecnologias, atendo-se, assim, às externalidades econômicas, sociais e políticas existentes, que proporcionam alterações substanciais nas demandas de mercado.

2. Gerência média com conhecimento do mercado (estrutura e logística de funcionamento) e do viajante (suas características, suas demandas e desejos), que saiba realizar o gerenciamento de rotina de trabalho, de equipes e de conflitos, e que tenha excelente relacionamento interpessoal, com domínio claro das novas tecnologias.

3. Trabalhadores de nível operacional que, além de conhecimentos técnicos específicos, e domínio das tecnologias, tenham conhecimento do local, do viajante e de seus idiomas, com formações que contemplem aspectos comportamentais, respeito socioambiental, conhecimento da cultura local e também da cultura do viajante, além de habilidade no trato das diferenças.

4. Gestores públicos que entendam de políticas públicas e dos seus mecanismos, e, como essas políticas podem impulsionar o setor, conhecimento das regiões turísticas e com potencial turístico e capacidade de negociação com as administrações locais e a iniciativa privada para criação da sinergia necessária ao desenvolvimento do setor.

5. Empreendedores que conheçam as potencialidades locais e as formas de alavancagem de recursos. Os médios e pequenos, em particular, precisam ser preparados para a gestão do negócio de forma global, ou seja, gestão de pessoal, mercadológica, financeira e organizacional, além de avaliação de riscos inerentes aos negócios e visão de futuro para estruturação de novos negócios. 
O profissional do turismo preparado para o futuro precisa ter uma formação multi e interdisciplinar e, por isso, estimuladora da criatividade. Será o domínio das habilidades específicas de sua ocupação, a capacidade de compreensão sistêmica e a criatividade que constituirão o conjunto das características do trabalhador do setor de turismo. Para isso, ele precisa conhecer profundamente a realidade das localidades, as dinâmicas socioambientais dos destinos turísticos e o perfil e desejos dos turistas. Além de dominar as novas tecnologias que facilitam os serviços necessários as viagens. Ter conhecimentos antropológicos que the permitam respeitar as pluralidades culturais, étnicas e religiosas fazendo a interlocução das diferenças entre turistas e autóctones. (BRASIL, 2015a).

As demandas futuras requerem profissionais que saibam utilizar mais o seu capital intelectual do que o operacional. Isso requer investimentos, acima de tudo, em educação básica e educação para trabalho que reflita aspectos para uma educação libertadora, emancipatória, problematizadora e cidadã. Dessa forma, será preciso atentar aos componentes da qualificação, que passam pela aquisição de conhecimento, desenvolvimento de habilidades e mudança de atitudes.

É inegável que as exigências do setor de turismo estão relacionadas aos avanços tecnológicos, dos serviços e às demandas dos turistas, por outro lado, prevalece a informalidade, principalmente quando se considera empreendedores menores, os salários predominantes são baixos, as garantias dos trabalhadores, tais como o seguro desemprego e contribuição previdenciária, ficam comprometidas, bem assim o seu tempo livre, devido às jornadas não reguladas e extensas de trabalhos, além da necessidade de se complementar a renda com o uso desse tempo livre para se exercer alguma outra atividade. Ademais o emprego sazonal é uma prática, que visa atender os fluxos dos períodos de férias e feriados, levando à informalidade uma gama de ocupações do setor.

Para alterar esse quadro devem-se agregar ao desenvolvimento fatores sociais, o que significa "alargar as escolhas humanas atribuindo maior destaque à riqueza de vidas humanas, e não, de forma redutora, à riqueza das economias". (PNUD, 2015 p. 5). O trabalho digno ${ }^{14}$ é base fundamental para a riqueza das

Os quatro pilares da Agenda do Trabalho Digno: i. criar emprego e desenvolver as empresas. Este pilar implica reconhecer que a principal via para sair da pobreza é a existência de postos de 
economias e para a riqueza das pessoas, no entanto, ainda tende-se a conceitualizar o trabalho em termos econômicos e não em termos de desenvolvimento humano. (PNUD, 2015).

Percebe-se que ao longo da história econômica e social mundial, existem momentos altos e baixos relacionados ao desenvolvimento econômico e social, e, que a maioria das ações propostas para atenuar os efeitos negativos e/ou impulsionar os positivos, são implementadas em períodos de grandes crises mundiais, onde a principal demanda é alavancar a economia, pois se tem um entendimento equivocado de que o crescimento econômico leva consequentemente a inclusão social.

Sabe-se que o trabalho é fator essencial para o desenvolvimento econômico e social, mas cabe refletir como 0 trabalho em turismo pode reforçar 0 desenvolvimento humano. Como o trabalho em turismo pode contribuir para o crescimento pessoal e a riqueza das pessoas. O que pode garantir uma inclusão social pelo trabalho no setor de turismo. Conforme destaca o PNUD (2015, p. 51) o "desenvolvimento humano é um processo de ampliação do leque de escolhas das pessoas, pelo que está intimamente relacionado com o trabalho". Assim se estabelece uma relação positiva recíproca (figura 2).

trabalho e que é imperioso que a economia proporcione oportunidades de investimento, empreendedorismo, criação de emprego e meios de subsistência sustentáveis. ii. normas e direitos no trabalho. É preciso que existam oportunidades de representação que permitam às pessoas participar e expressar os seus pontos de vista a fim de conquistar direitos e respeito. O trabalho normativo da Organização Internacional do Trabalho é fundamental para assegurar o cumprimento e medir o progresso. iii. proteção social. São menos de $10 \%$ os cidadãos dos países mais pobres que se beneficiam de uma proteção adequada ao nível da segurança social. A proteção social de base, como os cuidados de saúde e a segurança, constitui a fundação para uma participação produtiva na sociedade e na economia. iv. governação e diálogo social. O diálogo social entre governos, trabalhadores e empregadores pode resolver problemas econômicos e sociais importantes, encorajar a boa governação, criar relações de trabalho sólidas e impulsionar o progresso econômico e social (PNUD, 2015 p. 216). 
Figura 2 - Sinergias entre trabalho e desenvolvimento

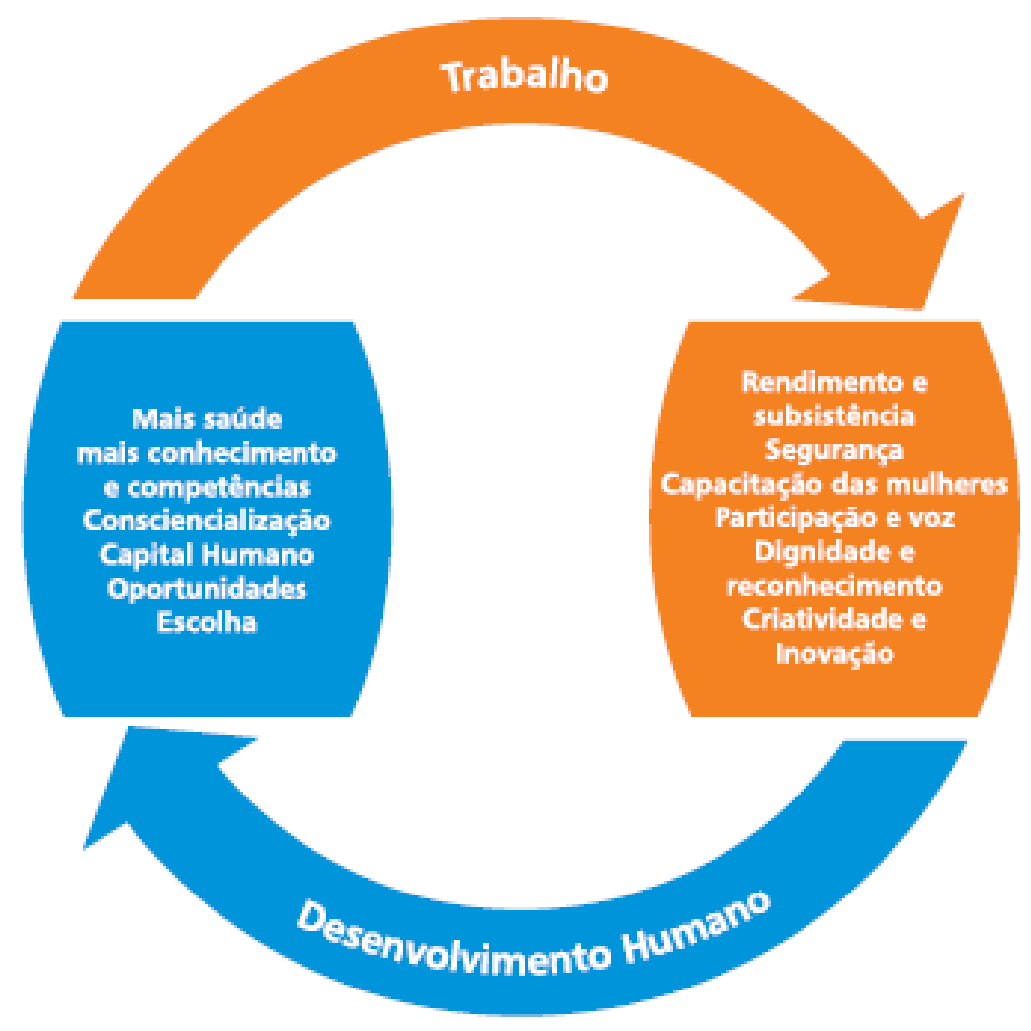

Fonte: PNUD, 2015

O desenvolvimento humano é afetado pelo trabalho através de muitos canais, os quais podem reforçar-se mutuamente (PNUD, 2015):

- Rendimento e meios de subsistência - As pessoas trabalham para alcançar um nível de vida digno. $O$ trabalho pode ser também um fator essencial para garantir que o crescimento econômico seja equitativo e contribua para a redução da pobreza.

- Segurança - propicia a construção de uma base segura para as suas vidas que Ihes permita tomar decisões a longo prazo e definir prioridades e escolhas.

- Capacitação das mulheres - como forma de empoderamento, autonomia econômica e maior poder de decisão no âmbito das famílias, dos locais de trabalho e das comunidades. Adquirem também confiança, segurança, e 
flexibilidade. Conforme exposto anteriormente, existem diversas oportunidades de trabalho no setor de turismo para as mulheres.

- Participação e voz - proporciona maior interação, participação na tomada de decisões em sociedade. O turismo pode proporcionar a participação social, se tiver atrelado ao processo virtuoso de formação/qualificação profissional, o qual permitirá desenvolver a criticidade e interesse pelos problemas da sociedade.

- Dignidade e reconhecimento - reconhecimento do bom desempenho profissional proporciona ao trabalhador um sentimento de realização, de autoestima e de identidade social.

- Criatividade e inovação - poder de libertar a criatividade humana e de gerar inovações que revolucionaram múltiplos aspetos da vida humana (como a saúde, a educação, as comunicações e a sustentabilidade ambiental).

Os trabalhadores do setor de turismo podem beneficiar-se de um maior desenvolvimento humano, veiculado aos processos de trabalho, tais como a aquisição de conhecimentos e competências que lhes permitam realizar com eficiência suas funções, aprimorar suas habilidades (profissionais e pessoais) e adquirir maior consciência para participar de forma plena em sociedade. " $A$ satisfação e a felicidade dos trabalhadores são elementos essenciais para reforçar os laços entre o trabalho e o desenvolvimento humano". (PNUD, 2015, p. 53).

$\mathrm{Na}$ contramão alguns empresários do setor de turismo aceitam, estimulam e até podem patrocinar o treino técnico do seu empregado, no entanto, rejeitam a formação, que envolve o saber técnico e científico indispensável, que proporciona a autonomia dos sujeitos no mundo. "Transformar a experiência educativa em puro treinamento técnico é amesquinhar o que há de fundamentalmente humano no exercício educativo: o seu caráter formador". (FREIRE, 1996, p. 37).

Verifica-se que o trabalho é fundamental para o desenvolvimento humano, no entanto existem milhares de pessoas desempregadas, ocupadas em trabalho vulnerável ou trabalham e permanecem na pobreza. Há uma discrepância em relação aos salários. Especificamente, no setor de turismo, não há planos de carreiras e apesar dos baixos salários existe a exigência por pessoal qualificado, mas não se paga o preço justo por esse serviço. 
A criação de oportunidades para utilizar o potencial de trabalho de todas as pessoas poderia acelerar ainda mais o progresso humano, ajudar a superar défices de desenvolvimento humano que ainda subsistem e enfrentar os desafios emergentes de desenvolvimento.

\begin{abstract}
A noção de desenvolvimento humano precisa ser contextualizada para que se torne uma base analítica mais relevante para permitir fazer face aos desafios emergentes num mundo em mudança. As questões relacionadas com as capacidades e as escolhas individuais e coletivas e as prováveis compensações recíprocas entre elas em diversas situações, as possíveis hierarquias entre tais escolhas, as escolhas e capacidades (que refletem a noção de sustentabilidade) inter geracionais (para as gerações do presente, mas também do futuro) e o desenvolvimento humano em situações de choque e vulnerabilidade são elementos que terão de ser revisitados a fim de tornar o quadro atual mais robusto e pertinente para o futuro. (PNUD, 2015, p. 79).
\end{abstract}

A reflexão sobre algumas destas questões já começou. Foram propostas novas noções de bem-estar humano "bem-estar subjetivo e a felicidade" (PNUD, 2015, p. 94), mas como conseguir atingir todo o potencial dos trabalhadores do setor de turismo de modo a propiciar o efetivo desenvolvimento humanizador? Como acompanhar todas as mudanças em curso, estruturais, sociais, econômicas, tecnológicas e políticas?

As respostas para essas e outras questões podem estar no processo de educação/formação/qualificação de qualidade, ofertada ao longo da vida, com propósitos claros e bem definidos, que articulem a educação básica, técnica e superior ao aprendizado prático. No entanto, o caminho para atingir essas premissas, deve percorrer a concepção de políticas públicas que primem por uma educação problematizadora, visando ao desenvolvimento humano pelo trabalho. $\mathrm{Na}$ qual haja a integração de estratégias para ações direcionadas, estratégias para criação de oportunidades de trabalho, estratégias para garantia do bem-estar dos trabalhadores e a criação de uma agenda para ação, conforme figura 3 .

Pressupõe-se que é por meio das pessoas que se poderá processar uma real mudança que conduzirá aos almejados efeitos econômicos, sociais e ao aumento da competitividade pelo turismo. Nesse contexto, é essencial instituir um conjunto de políticas públicas que possam potencializar o desenvolvimento humano pelo trabalho em turismo. 
Figura 3 - Políticas para potencializar o desenvolvimento humano pelo Trabalho

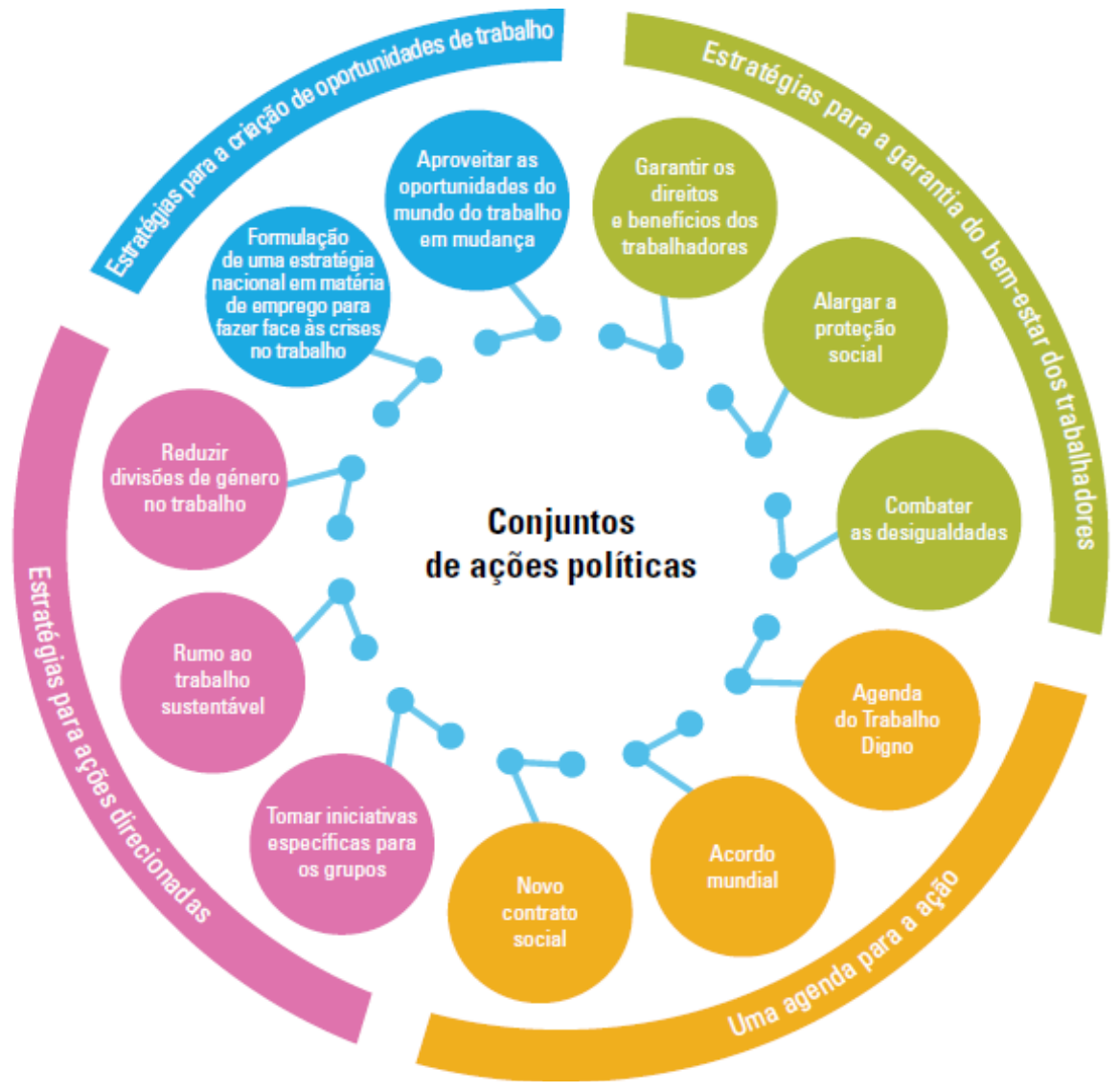

Fonte: PNUD, 2015

Para Sachs (2008) o desenvolvimento busca preparar os sujeitos para manifestar suas potencialidades, talentos e imaginação, em busca da autorrealização e da felicidade, mediante iniciativas individuais e coletivas, combinando trabalho autônomo e heterônomo e o tempo dedicado a atividades não produtivas, ou seja, lazer e descanso.

O desenvolvimento pode ser redefinido em termos da universalização e do exercício efetivo de todos os direitos humanos: políticos, civis, e cívicos; econômicos, sociais e culturais; bem como direitos coletivos ao desenvolvimento, ao ambiente etc. Embora os direitos sejam indivisíveis, deve ser dado um status especial ao direto ao trabalho, visto o seu duplo valor, intrínseco, mas também instrumental, já que o trabalho decente abre caminho para o exercício de vários outros direitos. (SACHS, 1998, p. 37).

Tem-se mais uma vez a certeza de que a educação é essencial para o desenvolvimento humano e social, na medida em que contribui para despertar a conscientização, a compreensão dos direitos humanos e o despertar cultural, 
aumentando a autonomia, autoconfiança e a autoestima dos sujeitos. Ademais contribui para a empregabilidade, não como um fim, mas como condição necessária para acesso ao trabalho decente.

Cabe chamar a atenção para a visão restrita de bem-estar social atrelada a quantidade e menos a qualidade de vida (DEMO, 1994) porque não basta ter um emprego se o mesmo não proporcionar uma vida digna, ou seja, a efetiva inclusão social, que conforme citado anteriormente, diz respeito à igualdade educacional, à valorização e reconhecimento dos sujeitos, acesso à formação e qualificação profissional, à segurança, aos bens e serviços, ao lazer, entre outros fatores de inclusão social. Segundo Sheppard (2006, p. 22):

[... [ a Inclusão social está relacionada com a procura de estabilidade social através da cidadania social, ou seja, todos os cidadãos têm os mesmos direitos na sociedade. A cidadania social preocupa-se com a implementação do bem-estar das pessoas como cidadãos.

$\mathrm{Na}$ figura 4 apresentam-se os fatores relacionados à inclusão social, no contexto geral e direcionados à sociedade em geral. Destaca-se que os benefícios da inclusão social, por meio da igualdade educacional - quando há um nível elevado de aprendizagem escolar, tende-se a reduzir o problema de desemprego.

Figura 4 - Fatores para a Inclusão Social

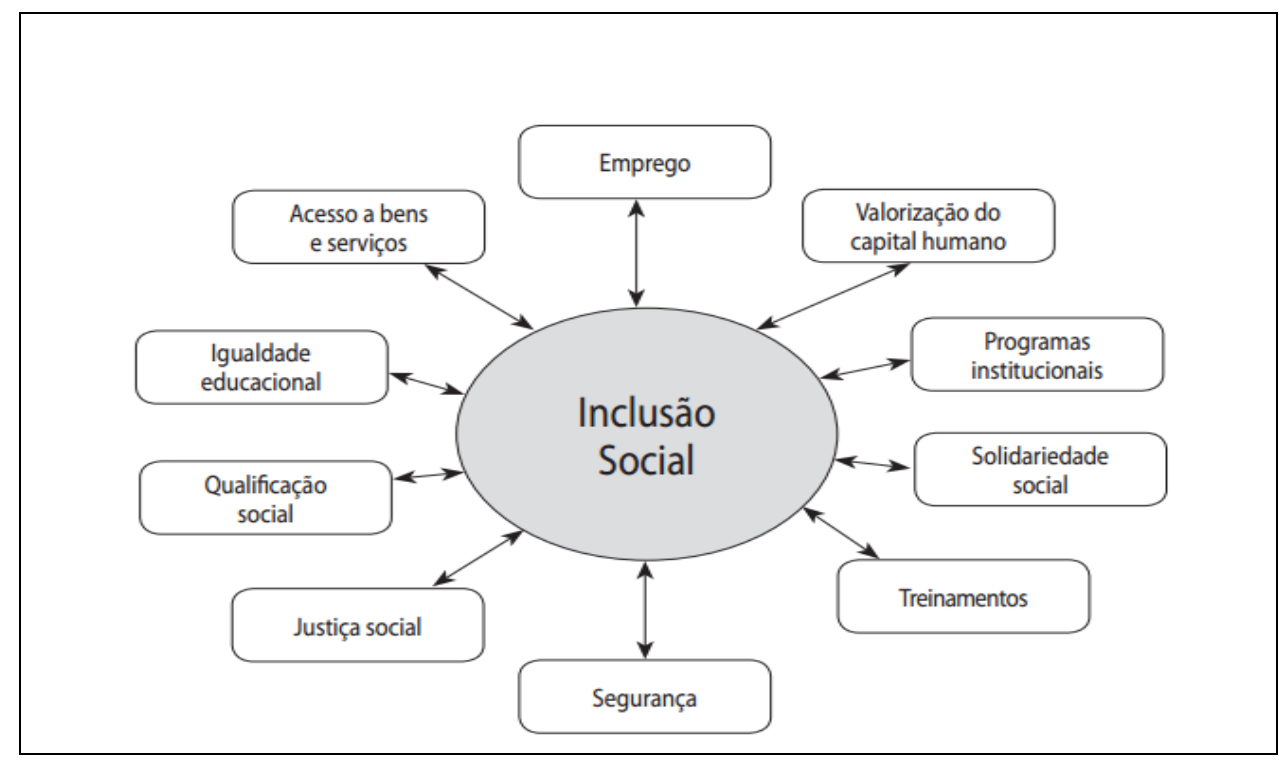

Fonte: Fatores de exclusão e inclusão social - Revista Serviço Social e Sociedade, São Paulo, n. 106, p. 219-240, abr./jun. 2011. 
Quando, em contrapartida, o nível de aprendizagem é baixo em geral o resultado gerado é o de uma situação de exclusão social (figura 5).

Figura 5 - Fatores para a Exclusão Social

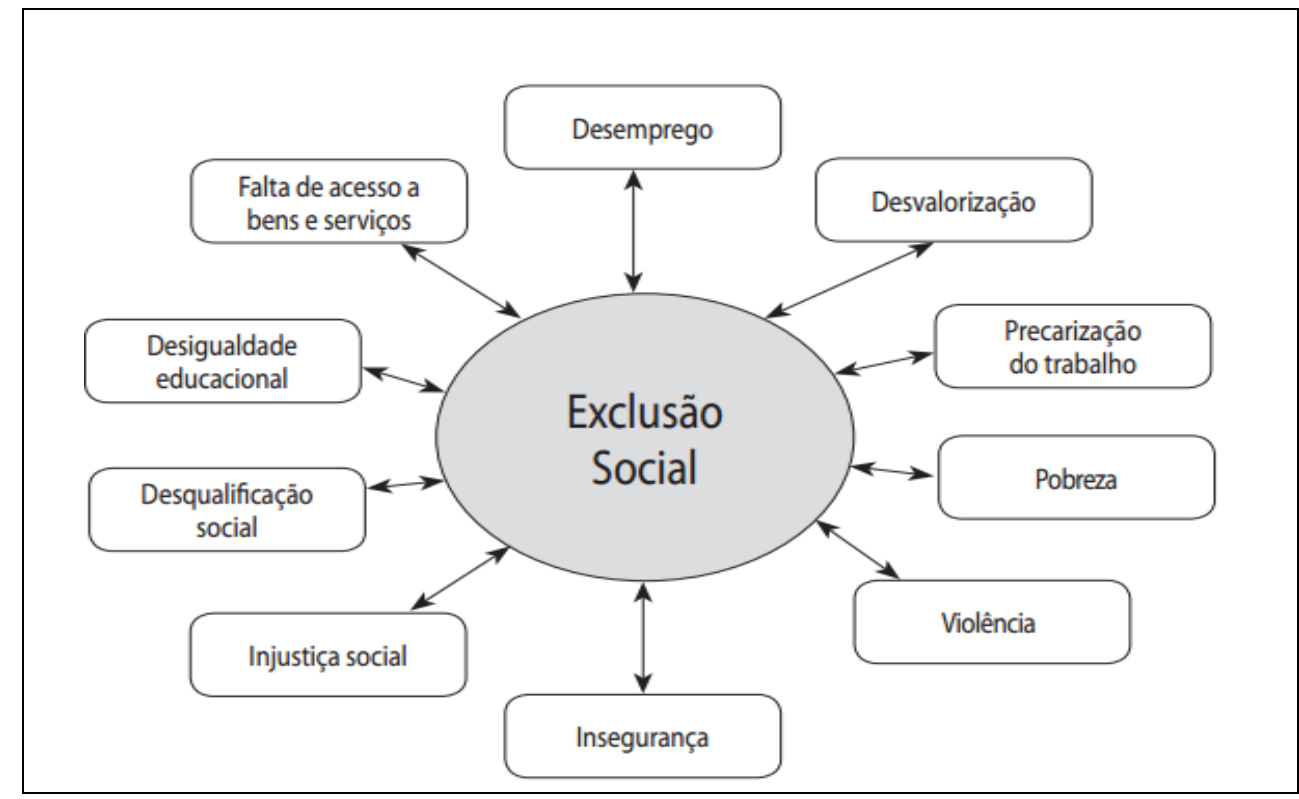

Fonte: artigo Fatores de exclusão e inclusão social - Revista Serviço Social e Sociedade. São Paulo, n. 106, p. 219-240, abr./jun. 2011.

De acordo com Sheppard (2006, p. 10), pode-se definir Exclusão Social como:

[...] grupos socialmente excluídos. Portanto, são aqueles que estão em situação de pobreza, desemprego e carências múltiplas associadas e que são privados de seus direitos como cidadãos, ou cujos laços sociais estão danificados ou quebrados.

No que concerne ao turismo é necessário pontuar que essa atividade pode proporcionar inclusão social via educação/qualificação/formação profissional, acesso a empregos dignos, ao lazer e ao descanso, ao desenvolvimento social e de regiões, entre outros benefícios. No entanto, mesmo esse processo de inclusão social, pode acarretar em exclusão dissimulada, uma vez que os profissionais do setor (trabalhadores em meios de hospedagem, agências, operadoras, bares e restaurantes, entre outros) comumente sentem-se inferiorizado por prestar um serviço que demande "hospitalidade e alegria de servir", enquanto os turistas estão no seu momento de lazer e descanso. (KRIPPENDORF, 2001). 
Esses profissionais dependem do turismo, que se constitui de importante fonte de emprego e renda, assim o turista é bem vindo porque fornece os insumos para sua sobrevivência financeira, mas, por outro lado pode ser visto como um intruso, um fardo, se as condições de trabalho desse profissional não forem atendidas de maneira digna, ou seja, empregos que proporcionem uma aprendizagem constante, e crescimento profissional, bem como salários justos e momentos de descanso e lazer.

Em contrapartida, os empresários do setor possuem as condições de inclusão social, uma vez que permanecem com grande parte dos lucros obtidos, "o turismo representa, nesse caso, um negócio puramente comercial. Ele deve proporcionar o máximo em volumes de venda e lucros. Como consegui-lo não importa o fim justifica os meios". (KRIPPENDORF, 2011 p. 70).

Uma terceira parcela da população dos destinos turísticos está afeta à atividade, os habitantes locais, que não atuam diretamente no setor, mas possuem uma atividade profissional fornecedora de insumos para o turismo. Para esse público o turismo pode gerar inclusão, por proporcionar uma renda complementar, por meio de oferta de produtos necessários para produzir valor agregado ao setor, por exemplo, a distribuição de orgânicos para restaurantes ou de artesanatos locais para lojas de souvenires e para decoração de hotéis. Entretanto, aspectos da exclusão social estão presentes nessa parcela da comunidade local, devido à falta de acesso a bens e serviços, à precarização do trabalho, à desqualificação social, à desigualdade educacional e, a falta de acesso às atividades de lazer que estão voltadas ao atendimento do turista.

Os autóctones e o os homens da política também formam a população local afetada pelos aspectos da inclusão e exclusão social, estando o primeiro grupo muito mais propenso à exclusão, por tratar-se de uma parte da população que acaba segregada da atividade turística, que não tem oportunidade de atuar no setor e, muitas vezes, devido ao crescimento econômico, são repelidas para a periferia e não usufruem de nenhum benefício relacionado ao turismo. Em contrapartida o segundo grupo, os homens da política, que possuem uma condição social mais vantajosa, usufruem do turismo, quer na categoria financeira, como na de lazer. Ademais como planejadores do setor pensam, normalmente, nos benefícios 
econômicos que o turismo pode proporcionar as localidades e, muitas vezes em seu próprio. (KRIPPENDORF, 2001).

Um último grupo social afeto pelo turismo, os turistas, que nessa condição, possuem condições referentes à inclusão social, como: acesso a bens e serviços, ao descanso e ao lazer, que na atualidade podem ser considerados categorias para inclusão social, pois se trata de direito que deve ser a todos atribuído.

O turismo interage com esses direitos sob dois pontos de vista: do turista e do trabalhador do setor, tendo em vista que o lazer é a principal motivação do turismo e que as condições para um trabalho digno fazem parte das necessidades dos trabalhadores do setor, o profissional deve estar apto a atender às necessidades dos turistas, mas para isso ele precisa estar inserido em um processo de trabalho que Ihe garanta o desenvolvimento humano e cidadão pelo turismo, possibilitando à inclusão social.

A visão reducionista dos impactos positivos econômicos do turismo, em geral limitados a uma oportunidade na geração de emprego e renda, com o consequente e relativo acesso a bens e serviços, deve-se agregar os aspectos que contribuem para a valorização social como um todo. Nesse sentido, o desenvolvimento humano que o turismo pode proporcionar para somar aos fatores de inclusão social carece de um olhar e direcionamento no investimento em educação, qualificação e formação profissional mais emancipadora do sujeito em relação ao processo socioeconômico.

Essa visão tecnocrática economicista que continua acreditando que o desenvolvimento social aparece em decorrência apenas do crescimento econômico (DEMO, 1994), não mais satisfaz, porque muitos outros fatores estão implicados nessa relação. O crescimento da economia até pode potencializar esses fatores se estiver atrelado a políticas públicas consistentes e com foco primordial nos sujeitos.

Existem estratégias de desenvolvimento que devem ser potencializadas para efetivar a inclusão social, por meio de ações direcionadas à educação, ciência e tecnologia; crescimento econômico; modernização da produção e do Estado; sustentabilidade ambiental e social; equalização de oportunidades e cidadania. (DEMO, 1994). 
Do ponto de vista da política social é necessário no plano socioeconômico criar condições de emprego e de acesso à renda, potencializando a capacidade da economia de gerar empregos e garantir a participação equilibrada das rendas geradas; oferecer condições a preparação das pessoas para o mercado de trabalho e condições de consumo de bens e acesso a serviços como os de transportes e os de lazer. No plano participativo acesso universal a educação, a cultura, ao patrimônio histórico, a informação e a liberdade de expressão, aos direitos fundamentais e participação social. (DEMO, 1994).

O bem-estar social deve ser uma conquista de uma sociedade atuante, uma construção própria, uma elaboração consciente e crítica, como decorrência da cidadania.

Ao se potencializar o desenvolvimento humano pela educação e pelo trabalho se estimula também a inclusão social, pessoas preparadas e inseridas em um mercado de trabalho digno têm condições de se projetarem socialmente e de acompanharem as crescentes mudanças e transições do mundo do trabalho e da sociedade em geral. Ao utilizarem do seu potencial criativo, crítico e participativo, operacionalizam a cidadania.

É intrínseca ao desenvolvimento humano a cidadania que abrange três âmbitos: o civil, o político e o social. Sobre esse aspecto, Silva (2000, p.127) afirma que:

[...] a cada um destes elementos corresponde um conjunto de direitos. A saber, a cidadania civil é formada pelos direitos necessários à liberdade individual; a cidadania política pelos direitos de participação no exercício do poder político; e a cidadania social pelo conjunto de direitos, que inclui segurança e bem-estar econômico, o direito de compartilhar a riqueza socialmente produzida e o de viver uma vida civilizada, segundo os padrões sociais vigentes.

"O pleno exercício da cidadania supõe direitos civis, direitos políticos [...] e direitos sociais (regulação do trabalho, aposentadoria, alimentação, habitação, saúde e educação) e direitos culturais". (GASTAL; MOESCH, 2007, p. 31). Infere-se que para obtenção de uma vida digna, inclui-se entre esses preceitos o direito ao lazer, essencial para a consolidação da cidadania. Desse modo, o Turismo interage com esses direitos sob dois pontos de vista: do turista e do trabalhador do setor. Tendo em vista que o lazer é a principal motivação do turismo e que as condições 
para um trabalho digno fazem parte das necessidades dos trabalhadores do turismo, o profissional do setor deve estar apto a atender às necessidades dos turistas, mas para isso ele precisa estar inserido em um processo de trabalho que lhe garanta o desenvolvimento humano e cidadão pelo turismo, possibilitando a inclusão social.

No Brasil existe uma inércia em relação à participação social e cidadã, o que é base para uma sociedade despolitizada, indiferente em relação às questões públicas, individualizada pela atomização, pela competição e por uma instrumentalização de tudo que diz respeito ao mundo. (ARENDT, 2001).

Corrobora com essa visão o que se infere da educação profissional em voga no Brasil que, atua prioritariamente, visando uma aprendizagem baseada na repetição, na imitação, nas rotinas, sem dialogar verdadeiramente com metodologias, técnicas e conteúdos que proporcionem uma educação virtuosa.

A urgência de educação para a cidadania é fundamental para recuperar um modo de vida ativa em sociedade - trabalho, obra, ação, condições básicas para que o homem viva sua plenitude na terra (FAVERO; CASAGRANDA, 2012) e, essa vida plena poderá ser realizada se os sujeitos estiverem preparados "qualificados" para colocar em prática os seus conhecimentos, habilidades e atitudes, não só em prol do trabalho, mas, também para a criação (criatividade) e participação cidadã.

A educação emancipatória e cidadã deve ser prioridade das políticas públicas, por permitir equalizar seus efeitos na sociedade de forma mais dinâmica e includente e proporcionar o atingimento efetivo das metas para o desenvolvimento. Neste contexto, a cidadania é uma conquista, parte de um processo de emancipação, que se constrói por meio da educação profissional integral da sociedade.

Trata-se de um processo de inclusão social pelo qual todas as pessoas de uma sociedade anseiam. Assim, uma educação que proporcione a aprendizagem e o conhecimento deve atuar em torno de quatro aprendizagens ao longo da vida: aprender a conhecer, aprender a fazer, aprender a viver juntos e aprender a ser, essas quatro premissas possibilitam uma educação cidadã e emancipatória, ou seja, visam preparar os sujeitos para compreender o mundo, desenvolver suas capacidades profissionais e comunicar; para agir, colocar em prática os conhecimentos adquiridos; para participar e cooperar em sociedade, realização de 
projetos comuns e gerir conflitos; e, finalmente para desenvolver sua personalidade e agir com autonomia, discernimento e reponsabilidade. (UNESCO, 1998).

Conforme já abordado, o turismo enaltecido nos discursos das políticas públicas aparece como importante instrumento de inclusão social, principalmente pelo viés econômico da geração de emprego e renda, mas é preciso ter consciência de que tentar alavancar o setor apenas pelo viés do crescimento não é suficiente, porque o efetivo desenvolvimento integrado do setor depende de pessoas, e essas devem estar inseridas em um processo virtuoso de educação, somente com a incidência de uma nova mentalidade e de novas propostas de políticas públicas para o Turismo se poderá efetivar a inclusão social e o desenvolvimento humano pelo trabalho em Turismo.

\subsection{Políticas públicas, educação, formação profissional}

O espaço político, segundo Arendt (2001) deveria estar pautado na ação e no discurso dos indivíduos que compõem a sociedade, onde cada um projeta suas necessidades, expectativas e interesses entre pares. No entanto, a política pública que vem pautando o País desde os primórdios foi concebida de forma antagônica a estes ideais, há muito tempo desconsidera a ação, o discurso, a divergência e a participação efetiva do homem, emergindo assim um comportamento político estruturado em consensos e acordos que beneficiam apenas uma ínfima parcela da sociedade.

A noção de que os homens só podem viver juntos, de maneira legítima e política, quando alguns têm o direito de comandar e os demais são forçados a obedecer. A noção vulgar que já encontramos em Platão e Aristóteles, de que toda comunidade política consiste em governantes e governados. (ARENDT, 1983, p. 234 apud MORAES, 2005, p. 7).

O espaço político como espaço de participação cidadã esvaziou, não se concretiza na prática, pois as políticas públicas são concebidas em estreita consonância com o mercado e com o crescimento econômico. Desse modo a participação social e cidadã fica comprometida, uma vez que esse direito não está assegurado de forma plena a todos, as pessoas não são preparadas para conhecer e participar efetivamente da vida política. 
A política se faz para suprir as necessidades vitais dos homens e não em função da participação efetiva em sociedade, para o exercício da democracia. A maior expressão da ação e do discurso da política traz em seu bojo a presença ativa do cidadão vinculada aos seus interesses e motivações e não a instâncias externa, como a vontade geral, o Estado e o contrato social. (ARENDT, 2001).

Comumente a política pública pode ser definida em três categorias, na primeira engloba tudo o que diz respeito à vida coletiva das pessoas, em sociedade e em suas organizações; na segunda trata de um conjunto de processos, métodos e expedientes usados por indivíduos ou grupos de interesse para influenciar, conquistar e manter o poder, e, em terceiro lugar a política é também a arte de governar e realizar o bem comum. (HEIDEMANN; SALM, 2014).

$\mathrm{Na}$ prática a política é entendida como ações, diretrizes e orientações, embasadas e expressas em leis e empreendidas como funções do Estado por um governo, ou organizações que o represente para buscar resolver questões da sociedade. Nesta perspectiva o Estado passa a exercer um papel fundamental na vida social, especialmente por meio do planejamento, que implica políticas previamente definidas para o alcance geral e setorial.

Para Demo (1991) a política ocorre nos espaços de relações sociais, e, não há relações sociais que não sejam políticas, pois os homens são diferentes e essas diferenças proporcionam as desigualdades. A sociedade se estrutura em torno das desigualdades e muda por causa das desigualdades. O espaço da política é também o espaço do poder, onde se administram as discriminações sociais e por meio de políticas buscam minimizá-las. Estando o governo nas mãos de poucos, a disputa do poder é reduzida e a participação social é quase nula, restando à maioria apenas obedecer às normas e leis.

Historicamente as políticas públicas surgem a partir de problemas sociais, ou seja, a partir de determinadas dificuldades sociais em que o tecido social não é mais capaz de absorver esses problemas. Assim torna-se necessário que o Estado regule através de Leis e Programas a sociedade para promover o bem-estar social. $\mathrm{Na}$ prática, percebe-se que a promoção do bem-estar social está atrelada ao incremento da economia, que é tido como fator essencial para a geração de empregos e renda, dessa forma as políticas públicas se voltam prioritariamente para as necessidades 
do mercado, que atuam como força motriz quase exclusiva na condução da sociedade e da economia.

No intervalo entre as duas guerras mundiais, o Estado e os mercados passaram a promover em conjunto o desenvolvimento das sociedades. A ação política dos governos veio a se expressar de duas formas: ação reguladora - criação de leis que imprimiam direcionamentos específicos de ordem política às iniciativas econômicas e como participação direta na economia, com função empresarial, por exemplo, com a criação dos órgãos para prover serviços como saúde, educação, transporte público e a criação e gestão de empresas estatais ou paraestatais para a produção de serviços de infraestrutura. (HEIDEMANN; SALM, 2014).

Ademais, as Políticas Públicas são concebidas como um processo composto por um conjunto de atividades (etapas ou estágios) que visam atender às demandas e interesses das sociedades, como: preparação da decisão política, agenda setting $^{15}$, formulação, implementação, monitoramento e avaliação. (RODRIGUES, 2010).

Corrobora com essa visão o que expõe Howlett e outros apud Heidemann; Salm, $(2014)^{16}$, que o processo para policy-making ${ }^{17}$ se desdobra em cinco estágios: o estabelecimento ou montagem da agenda (de acordo com os problemas demandados); a formulação de política (o modo como as propostas são formuladas); a tomada de decisão política (processo pelo qual os governos adotam um curso de ação ou inação); a implementação da política (como os governos dão efetividade à política) e a avaliação da política (como os atores estatais e societário monitoram os resultados da política). Processo este que pode resultar na requalificação dos problemas e das soluções.

Toda política que expressa uma estratégia conservadora, de mero crescimento ou de desenvolvimento, manifesta-se por níveis de etapas de ação do Estado, que vão desde o simples intervencionismo, passando pelo dirigismo, até às possíveis variantes do planejamento Kaplan (1971).

\footnotetext{
${ }^{15}$ A agenda setting é utilizada pela comunicação social, e por atos políticos de forma a poderem atingir os seus objetivos, fazer que sejam eles a dizer o que devemos pensar e o que pensar (RODRIGUES, 2010).

${ }^{16}$ HOWLETT, Michael; RAMESH, M.; PERL, Anthony. Política pública: seus ciclos e subsistemas: uma abordagem integradora. Tradução técnica de Francisco G. Heidemann. Rio de Janeiro: Elsevier, 2013.

${ }^{17}$ Decisões políticas.
} 
É mister salientar a importância do planejamento, que de acordo com Gross (1971) consiste de decisão prévia ou pressão externa (demandas da sociedade para resolver um problema estrutural), podendo ser espontâneo, negligente ou ocasional.

Independente das variantes, o planejamento é uma atividade complexa e permanente, com distintas funções, tarefas e etapas que se desenvolvem com o tempo. Representa um conjunto de atos que configura um processo singular dentro de outro processo mais geral, o das decisões do poder político. A atividade planejadora do Estado, sua formulação e execução pressupõem e exigem uma decisão política permanente.

Deste modo, fica evidente que o planejamento é intrínseco na elaboração/implementação e execução das políticas públicas, tendo como processo chave a participação social, desejável em todas as etapas, mas na prática isso não ocorre. Ainda, é necessário ressaltar que todo esse processo deve ter como cerne o efetivo desenvolvimento econômico e social, ambos no mesmo patamar, porque não há desenvolvimento se essas duas premissas caminharem separadamente, tampouco se as políticas públicas visarem o atendimento dos interesses privados dominantes, fato comumente verificado na experiência das políticas públicas destinadas ao turismo e hospitalidade.

No Brasil a falta de planejamento adequado causa enormes descompassos nas ações propostas pelos governos, levando-as, muitas vezes, ao fracasso, tanto econômico como social. Existem profissionais competentes atuando na gestão pública para buscar promover ações viáveis e sustentáveis do ponto de vista econômico e social, mas falta sintonia com o poder político que preferem ações imediatistas que thes deem retorno mais rápido, ou seja, atender esferas da sociedade que Ihes garantam a sua manutenção no poder, e esse é um ciclo extremamente vicioso no nosso País. Problema que se perpetua no turismo, onde o interesse de grandes empresas e do governo em otimizar o crescimento econômico pelo turismo, está à frente do interesse social e do desenvolvimento humano.

Ademais, a burocracia e o formalismo são fatores que engessam a atuação do Estado, por demandarem muito mais tempo que a iniciativa privada para colocar uma ação planejada em execução, e, quando isso acontece, muitas vezes já não atende ao que se propunha, sendo considerada uma iniciativa obsoleta. Outro ponto 
que compromete é a falta de avaliação das ações executadas o que gera um descontrole em relação à efetividade das políticas propostas, fator essencial para medir e corrigir rumos das políticas públicas em execução.

Seguindo as ideias de Bustelo (1982) o planejamento social se define como conjunto de técnicas, métodos e procedimentos para desenvolver a política social abrangendo uma interferência programada na sociedade com o objetivo de alcançar uma parcela dessa sociedade, na qual o princípio de igualdade na distribuição da riqueza e da renda tenda a ser maximizado.

O planejamento é uma ferramenta que visa desenvolver ou sistematizar políticas públicas de forma a atender as demandas da sociedade, é um caminho para se buscar a efetividade das ações rumo ao desenvolvimento econômico e social. A participação social deve ser igualmente instrumento e finalidade, para Demo (1981) consiste de um instrumento essencial de promoção social, porque é através dela que se chega à autopromoção, mas, é também finalidade, porque a autopromoção é participação.

A atuação da administração pública já não atende adequadamente as demandas sociais, por isso, o seu desafio torna-se cada vez maior, pois além da provisão direta de alguns serviços essenciais para a sociedade é necessário prover o Estado de Políticas públicas eficientes que possam ser executadas em parceria por empresas e organizações não governamentais para se buscar preencher essa lacuna.

A grande promessa da política social é combater a pobreza, sendo a economia um instrumento primordial, pois por meio da economia surgem os trabalhos, para alavancar esse processo, por meio da geração de ocupação e renda, gerando um ciclo de produção e consumo. Assim o trabalho que é gerado pela economia é uma forma estrutural de distribuir renda. (DEMO, 1991).

Compreendem as políticas sociais as voltadas à saúde, educação, habitação, alimentação, água, saneamento, energia, subsídios monetários (bolsa família, por exemplo) e previdência social. Para Parente (2010) as políticas adjacentes como as de combate à inflação, investimentos produtivos, infraestrutura e as de segurança pública têm um componente social, por meio da geração de emprego, distribuição de renda, melhoria da qualidade de vida e bem estar dos cidadãos. 
Verifica-se o importante papel das políticas públicas, que necessitam ser efetivadas para além das demandas econômicas e do interesse de uma minoria que detém o poder, buscando atuar de forma prioritária rumo ao desenvolvimento humano e social.

No rol das políticas públicas primordiais para o desenvolvimento humano e social do país estão as políticas educacionais, componentes das políticas públicas sociais, que visam uma maior qualidade de vida para a sociedade, tendo em vista que a educação consiste de ferramenta capaz de elevar a autoestima dos cidadãos e proporcionar a sua autonomia como ser social. "A política pública educacional embora seja constituída por um conjunto de agentes, ela se desenvolve no âmbito da estrutura do Estado, que deve prover as diretrizes, regulamentos, normas e leis para sua execução de forma igualitária”. (PARENTE, 2010, p. 118).

Dentre essas leis, destacam-se a Lei de Diretrizes e Bases da Educação (LDB) - Lei no 9.394, de 20 de dezembro de 1996 e o Plano Nacional de Educação (PNE) - Lei no 13.005, de 25 de junho de 2014).

De acordo com a LDB os Princípios e Fins da Educação Nacional são:

Art. $2^{\circ}$ A educação, dever da família e do Estado, inspirada nos princípios de liberdade e nos ideais de solidariedade humana, tem por finalidade 0 pleno desenvolvimento do educando, seu preparo para o exercício da cidadania e sua qualificação para o trabalho.

Art. 3ㅇ $O$ ensino será ministrado com base nos seguintes princípios:

I - igualdade de condições para o acesso e permanência na escola;

II - liberdade de aprender, ensinar, pesquisar e divulgar a cultura, o pensamento, a arte e o saber;

III - pluralismo de ideias e de concepções pedagógicas;

IV - respeito à liberdade e apreço à tolerância;

$V$ - coexistência de instituições públicas e privadas de ensino;

VI - gratuidade do ensino público em estabelecimentos oficiais;

VII - valorização do profissional da educação escolar;

VIII - gestão democrática do ensino público, na forma desta Lei e da legislação dos sistemas de ensino;

IX - garantia de padrão de qualidade;

$X$ - valorização da experiência extraescolar;

$X I$ - vinculação entre a educação escolar, o trabalho e as práticas sociais.

XII - consideração com a diversidade étnico-racial. (BRASIL. Lei № 9.394, 1996, art. $2^{\circ}$ e $3^{\circ}$ ).

A LDB é a lei de referência da educação no País, que disciplina a educação escolar, apresenta a sua organização, compreendendo os deveres e obrigações do 
governo federal, distrital, estadual e municipal, da iniciativa pública e privada. Dispõe a respeito dos níveis e das modalidades de educação e ensino (educação básica formada pela educação infantil, ensino fundamental e ensino médio, educação profissional técnica; educação superior e educação profissional tecnológica), conforme figura 6 e o modo de gestão financeira da educação pública.

Figura 5 - Organização da Educação Brasileira (Lei 9.394/1996)

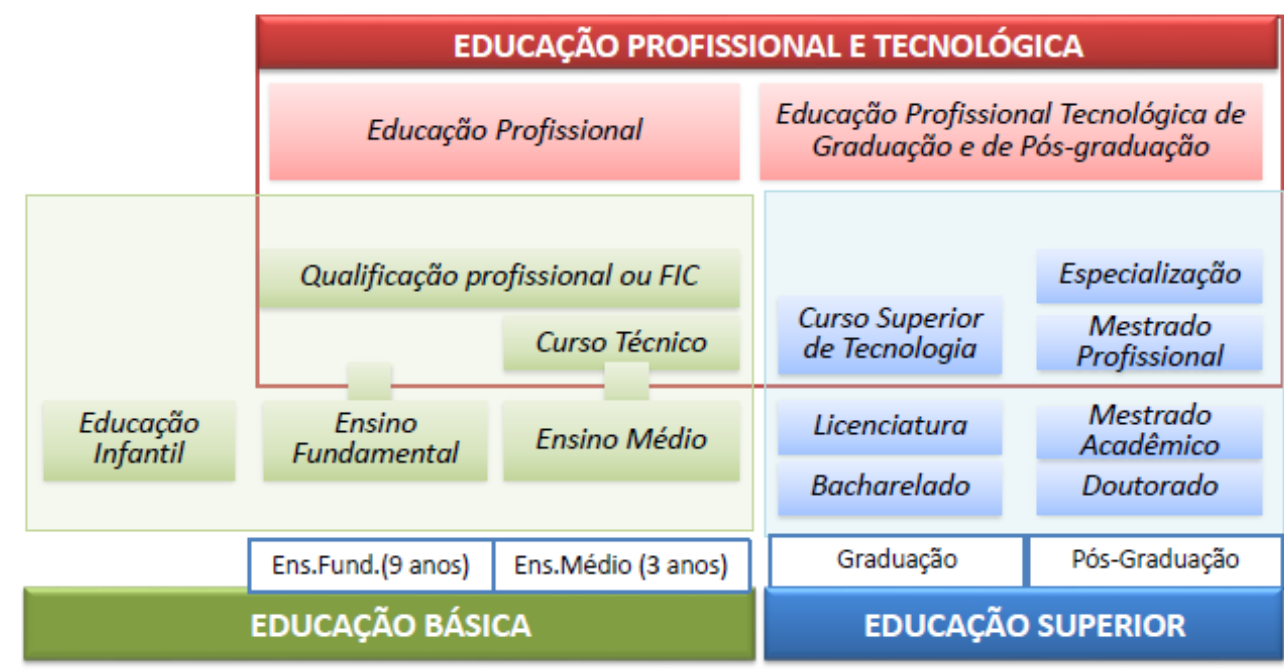

Fonte MEC, 2015

Outro documento norteador da educação nacional é o PNE (2014-2024), que traz em sua concepção as seguintes diretrizes:

I - erradicação do analfabetismo;

II - universalização do atendimento escolar;

III - superação das desigualdades educacionais, com ênfase na promoção da cidadania e na erradicação de todas as formas de discriminação;

IV - melhoria da qualidade da educação;

$V$ - formação para o trabalho e para a cidadania, com ênfase nos valores morais e éticos em que se fundamenta a sociedade;

VI - promoção do princípio da gestão democrática da educação pública;

VII - promoção humanística, científica, cultural e tecnológica do País;

VIII - estabelecimento de meta de aplicação de recursos públicos em educação como proporção do Produto Interno Bruto - PIB, que assegure atendimento às necessidades de expansão, com padrão de qualidade e equidade;

IX - valorização dos (as) profissionais da educação;

$X$ - promoção dos princípios do respeito aos direitos humanos, à diversidade e à sustentabilidade socioambiental (BRASIL. Lei ํㅡㄹ 13.005, 2014, art. $2^{\circ}$ ). 
O PNE apresenta, ainda, as metas e estratégias, que se destinam à educação nacional, institui, também, o Fórum Nacional de Educação, responsável por acompanhar a execução e o cumprimento das metas do Plano.

Ao se atentar as diretrizes do PNE, é possível observar que elas coadunam com os objetivos expressos na Constituição de 1988:

\footnotetext{
[...] construir uma sociedade livre, justa e solidária; garantir o desenvolvimento nacional, erradicar a pobreza e a marginalização e reduzir as desigualdades sociais e regionais e promover o bem de todos, sem preconceitos de origem, raça, sexo, cor, idade e quaisquer outras formas de discriminação. (BRASIL. CF, 1988 art. $3^{\circ}$ ).
}

Nesse sentido verifica-se que a educação tem um importante papel na formação/qualificação dos indivíduos, tanto para a produção científica, como para o desenvolvimento econômico e social, sendo um fator determinante para o alcance do objetivo constitucional de erradicar a pobreza e a marginalização e reduzir as desigualdades sociais e regionais e promover o bem de todos. (PARENTE, 2010).

Verifica-se que a estrutura da política pública de educação instituída na LDB e no PNE, está alicerçada em premissas que visam ao desenvolvimento humano e a inclusão social, entretanto ao se constituir as ações e os programas para colocar em prática esses princípios e diretrizes não se percebe essa transposição. Assim, apesar das propostas se alinharem às perspectivas do desenvolvimento integral dos sujeitos, na realidade isso não ocorre, porque permanece a visão reducionista de que apenas o crescimento econômico gera a inclusão social.

Como o objeto desta pesquisa é a educação profissional o foco da análise estará centrado na política pública de educação profissional de uma forma geral portanto, buscou-se contextualizar as políticas públicas de educação profissional planejadas e executas no Brasil, desde os tempos mais remotos.

A história da educação profissional no Brasil tem várias experiências registradas a partir de 1800 , tendo como parâmetro os documentos Centenário da Rede Federal de Educação Profissional e Tecnológica (MEC, 2009), Políticas Públicas de Qualificação: desafios atuais (Saul; Freitas, 2007), os livros Educação no Mundo do Trabalho: qualificação e competência (Castioni, 2010) e A Trajetória da Educação Profissional no Brasil e os Desafios da Construção de um Ensino Médio 
Integrado à Educação Profissional (Canali, 2014) elaborou-se um histórico da educação profissional.

A formação do trabalhador no Brasil começou a ser feita desde os tempos mais remotos da colonização, tendo como os primeiros aprendizes de ofícios os índios e os escravos, e "habituou-se o povo de nossa terra a ver aquela forma de ensino como destinada somente a elementos das mais baixas categorias sociais". (FONSECA, 1961, p. 68). Esse modelo se destinava à camada menos privilegiada da sociedade brasileira. As crianças e os jovens recebiam além da instrução primária, a aprendizagem de ofícios, tais como: tipografia, encadernação, alfaiataria, tornearia, carpintaria, sapataria, entre outros.

Neste mesmo período Dom João VI cria Colégio das Fábricas, considerado o primeiro estabelecimento instalado pelo poder público, com o objetivo de atender à educação dos artistas e aprendizes vindos de Portugal. (BRASIL, 2009e).

Ainda, em Minas Gerais, com o advento do ouro, surgiram as Casas de Fundição e de Moeda e com elas a necessidade de um ensino mais especializado, destinado aos filhos de homens brancos empregados da própria Casa. Pela primeira vez, estabelecia-se uma banca examinadora que deveria avaliar as habilidades dos aprendizes adquiridas em um período de cinco a seis anos. Caso fossem aprovados, recebiam uma certidão de aprovação. Nesse mesmo período, nos Arsenais da Marinha no Brasil, foram criados os Centros de Aprendizagem de Ofícios, os quais traziam operários especializados de Portugal e recrutavam pessoas que tivessem alguma condição de produzir. (BRASIL, 2009e).

No início do século XX, o governador do Rio de Janeiro, Nilo Peçanha, iniciou no Brasil o ensino técnico por meio do Decreto $n^{\circ} 787$, de 11 de setembro de 1906 , criando quatro escolas profissionais naquela unidade federativa: Campos, Petrópolis, Niterói, e Paraíba do Sul, sendo as três para o ensino de ofícios e a última destinada à aprendizagem agrícola. (BRASIL, 2009e).

Neste mesmo período foi realizado o "Congresso de Instrução" no qual foi apresentado ao Congresso Nacional um projeto de promoção do ensino prático industrial, agrícola e comercial, mantido com o apoio conjunto do Governo da União e dos Estados. O projeto previa a criação de campos e oficinas escolares onde os 
alunos dos ginásios seriam habilitados, como aprendizes, no manuseio de instrumentos de trabalho. (BRASIL, 2009e).

Em 1909, foi instituído o Decreto n 7.566, de 23 de setembro de 1909, que oficializou a educação profissional brasileira que, vista como instrumento de capacitação ou adestramento para atender ao crescente desenvolvimento industrial e ao ciclo de urbanização, tinha caráter assistencialista em relação à massa trabalhadora. Foram criadas, ainda, dezenove "Escolas de Aprendizes Artífices" (CEFET's), destinadas ao ensino profissional, primário e gratuito, em diferentes unidades federativas, sob a jurisdição do Ministério dos Negócios da Agricultura, Indústria e Comércio. (BRASIL, 2009e).

No período compreendido entre os anos 1927 a 1937 o Congresso Nacional sancionou o do Projeto de Fidélis Reis que previa o oferecimento obrigatório do ensino profissional no país; foram instaladas escolas superiores para formação de recursos humanos necessários ao processo produtivo (início da Industrialização do Brasil); houve uma expansão do ensino profissional no Brasil, incluindo, em seu público-alvo, ricos e pobres, foi um período de grande ampliação do ensino industrial, impulsionada por uma política de criação de novas escolas industriais e introdução de novas especializações nas escolas existentes. A Constituição brasileira de 1937 foi a primeira a tratar especificamente de ensino técnico, profissional e industrial, estabelecendo no artigo 129:

\footnotetext{
O ensino pré-vocacional e profissional destinado às classes menos favorecidas é, em matéria de educação, o primeiro dever do Estado. Cumpre-lhe dar execução a esse dever, fundando institutos de ensino profissional e subsidiando os de iniciativa dos Estados, dos Municípios e dos indivíduos ou associações particulares e profissionais. É dever das indústrias e dos sindicatos econômicos criar, na esfera de sua especialidade, escolas de aprendizes, destinadas aos filhos de seus operários ou de seus associados. A lei regulará o cumprimento desse dever e os poderes que caberão ao Estado sobre essas escolas, bem como os auxílios, facilidades e subsídios a lhes serem concedidos pelo poder público" (BRASIL. Lei ํo art. 129).
} 
Em 13 de janeiro de 1937 foi assinada a Lei o 378 que transformava as Escolas de Aprendizes e Artífices em Liceus Profissionais, destinados ao ensino profissional, de todos os ramos e graus.

Entre os anos de 1940 a 1946 ocorreu a ampliação do atendimento da educação profissional, por meio da criação das instituições responsáveis pela formação de mão-de-obra para os dois principais pilares da economia: a Indústria e o Comércio - criação do serviço Nacional da Indústria (SENAI) e do Serviço Nacional de Aprendizagem Comercial (SENAC), do Serviço Social do Comércio (SESC) e Serviço Social da Indústria (SESI). Vigoraram uma série de leis conhecidas como a "Reforma Capanema" que remodelou todo o ensino no país, e tinha como principais pontos:

1. o ensino profissional passou a ser considerado de nível médio;

2. o ingresso nas escolas industriais passou a depender de exames de admissão;

3. os cursos foram divididos em dois níveis, correspondentes aos dois ciclos do novo ensino médio: o primeiro compreendia os cursos básico industrial, artesanal, de aprendizagem e de mestria. O segundo ciclo correspondia ao curso técnico industrial, com três anos de duração e mais um de estágio supervisionado na indústria, e compreendendo várias especialidades.

Em 1942 foi instituído o Decreto № 4.127, de 25 de fevereiro de 1942, transformando as Escolas de Aprendizes e Artífices em Escolas Industriais e Técnicas, passando a oferecer a formação profissional em nível equivalente ao do secundário. Iniciando, formalmente, o processo de vinculação do ensino industrial à estrutura do ensino do país ${ }^{18}$.

A partir de 1956 a 1961 o governo de Juscelino Kubitschek marcou pelo aprofundamento da relação entre Estado e a economia. Nesse período, a indústria automobilística surge como o grande ícone da consolidação da indústria nacional. O Plano de Metas do Governo JK nesses cinco anos prevê investimentos maciços nas áreas de infraestrutura (a produção de energia e ao transporte são conferidos $73 \%$

\footnotetext{
18 Os alunos formados nos cursos técnicos ficavam autorizados a ingressar no ensino superior em área equivalente à da sua formação. (BRASIL, 2009e).
} 
do total dos investimentos). Pela primeira vez contempla-se o setor de educação com $3,4 \%$ do total de investimentos previstos. O objetivo era a formação de profissionais orientados para as metas de desenvolvimento do país. No ano de 1959, as Escolas Industriais e Técnicas são transformadas em autarquias com o nome de Escolas Técnicas Federais. As instituições ganham autonomia didática e de gestão. Com isso, intensifica a formação de técnicos, mão de obra indispensável diante da aceleração do processo de industrialização. Em 1963, foi instituído o primeiro Programa Intensivo de Preparação de Mão-de-obra (PIPMO).

Na década de 1970 foi instituída a LDB, №. 5.692, de 11 de agosto de 1971, tornando, de maneira compulsória, técnico-profissional, todo currículo do segundo grau. Um novo paradigma se estabelece: formar técnicos sob o regime da urgência. Em muitas escolas de ensino de segundo grau foram criadas habilitações em Turismo. Nesse tempo, as Escolas Técnicas Federais aumentam expressivamente o número de matrículas e implantam novos cursos técnicos. Em 1978, com a Lei no 6.545, três Escolas Técnicas Federais (Paraná, Minas Gerais e Rio de Janeiro) são transformadas em Centros Federais de Educação Tecnológica (CEFETs). Esta mudança confere àquelas instituições mais uma atribuição, formar engenheiros de operação e tecnólogos, processo esse que se estende às outras instituições bem mais tarde. (BRASIL, 2009e).

Nos anos compreendidos entre 1990 e 1999 foi criado o Serviço Nacional de Aprendizagem Rural (SENAR), o Serviço Nacional do Transporte (SENAT), o Serviço Nacional de Apoio ao Cooperativismo (SESCOOP) e o Serviço Brasileiro de Apoio à Pequena e Média Empresa (SEBRAE).

Em 1994 foi sancionada a Lei № 8.948, de 8 de dezembro de 1994, que dispõe sobre a instituição do Sistema Nacional de Educação Tecnológica, transformando, gradativamente, as Escolas Técnicas Federais e as Escolas Agro técnicas Federais em Centros Federais de Educação Tecnológica (CEFETs). O Ministério do Trabalho lançou o Programa de Reciclagem Profissional, com a finalidade de integrar às ações do Sistema Nacional de Emprego (SINE) a oferta de cursos de qualificação profissional, de forma sistemática e consistente, ampliando o atendimento ao trabalhador desempregado. 
Em 1996 foi implementado o primeiro programa de qualificação profissional, Plano Nacional de Formação do Trabalhador (PLANFOR). Devido a sua importância como ação institucional, implementada pelo governo Federal, o Plano será detalhado mais adiante. (SAUL \& FREITAS, 2007).

Em 20 de novembro de 1996 foi sancionada a Lei oㅜ 9.394, considerada como a segunda LDB, que dispõe sobre a Educação Profissional num capítulo separado da Educação Básica, superando enfoques de assistencialismo e de preconceito social contido nas primeiras legislações de educação profissional do país, fazendo uma intervenção social crítica e qualificada para tornar-se um mecanismo para favorecer a inclusão social e democratização dos bens sociais de uma sociedade. Além disso, define o sistema de certificação profissional que permite o reconhecimento das competências adquiridas fora do sistema escolar. (SAUL \& FREITAS, 2007).

Em 1997 o Decreto № 2.208 regulamenta a educação profissional e cria o Programa de Expansão da Educação Profissional (PROEP). Em 1999 retoma-se o processo de transformação das Escolas Técnicas Federais em Centros Federais de Educação Tecnológica, iniciado em 1978. (BRASIL, 2009e).

No século XXI o Ministério do Trabalho e Emprego lança o Plano Nacional de Qualificação (PNQ), em julho de 2003, em substituição ao PLANFOR, pretendendo corrigir o rumo da educação profissional no País, dando um caráter de formação integral aos sujeitos, não se restringindo apenas ao treinamento para uma determinada ocupação.

O Ministério da Educação por meio do Decreto № 5.154/2004 permitiu a integração do ensino técnico de nível médio ao ensino médio. Com a publicação da Lei no 11.195/2005, ocorre o lançamento da primeira fase do Plano de Expansão da Rede Federal de Educação Profissional e Tecnológica, com a construção de 64 novas unidades de ensino. O Decreto no $5.773 / 2006$ dispõe sobre o exercício das funções de regulação, supervisão e avaliação de instituições de educação superior e cursos superiores de graduação e sequenciais no sistema federal de ensino. Decreto $n^{0}$ 5.840/2006 instituiu, no âmbito federal, o Programa Nacional de Integração da Educação Profissional com a Educação de Jovens e Adultos (PROEJA) com o ensino fundamental, médio e educação indígena. 
Neste mesmo ano é lançado o Catálogo Nacional dos Cursos Superiores de Tecnologia para disciplinar as denominações dos cursos oferecido por instituições de ensino público e privado. A Secretaria de Educação Profissional e Tecnológica (SETEC) do MEC, em parceria com o Fórum Nacional de Gestores Estaduais de Educação Profissional realizaram conferências em 26 Estados e no Distrito Federal, as quais culminaram, no período de 05 a 08 de novembro de 2006, com a $1^{\text {a }}$ Conferência Nacional de Educação Profissional e Tecnológica, marco importante na educação brasileira, com a participação de 2.761 pessoas, foi a primeira conferência que o Ministério da Educação realizou em toda a sua história. . (BRASIL, 2009e).

Em 2007 o MEC Lança a segunda fase do Plano de Expansão da Rede Federal de Educação Profissional e Tecnológica, tendo como meta entregar à população mais 150 novas unidades, perfazendo um total de 354 unidades, até o final de 2010, cobrindo todas as regiões do país, oferecendo cursos de qualificação, de ensino técnico, superior e de pós-graduação, sintonizados com as necessidades de desenvolvimento local e regional.

Um ano depois lança também o Catálogo Nacional dos Cursos Técnicos, importante instrumento de divulgação e regulação da oferta de cursos técnicos por todo o Brasil, cria os Institutos Federais (Lei oㅜ 11.892 de 2008). Em 2009, criação do Sistema Nacional de Informações da Educação Profissional e Tecnológica (SISTEC) e da Rede e-TEC para fomentar a oferta de cursos técnicos à distância.

Em 2011, o Governo Federal, instituí o Programa Nacional de Acesso ao Ensino Técnico e Emprego (PRONATEC), por meio da lei no 12.513 de 26 de outubro de 2011, nesse Programa a educação profissional passa a concentrar-se no MEC, tendo o MTE e o MDS como principais parceiros desse Programa, o primeiro responsável pela intermediação do pessoal qualificado para o mercado de trabalho via SINE, como também, por requalificar profissionais em situação de desemprego, ao MDS compete à responsabilidade de encaminhar pessoas que recebem auxílios do Governo Federal, como bolsa família a se qualificarem para o mercado de trabalho. Aos outros Ministérios a participação de dá pela identificação das demandas e articulação da execução e acompanhamento junto ao MEC. 
Em 2012, o Conselho Nacional de Educação (CNE), por meio da Resolução no 6 , de 20 de setembro, estabelece as diretrizes curriculares nacionais para a educação profissional técnica de nível médio.

Desse apanhado cabe ressaltar que a década de 1930 constitui-se de um referencial histórico para a educação profissional no Brasil, uma vez que nesse período se configurou o início da industrialização no País, surgindo à necessidade da formação de recursos humanos voltados para atender o processo produtivo. A partir de 1940 com o surgimento do sistema S ocorreu uma ampliação do atendimento da população pela educação profissional.

Outro ponto de destaque foi à implementação do PLANFOR, meados de 1996, esse plano se constituiu como pilar da nova institucionalidade da política de qualificação profissional brasileira (SILVA, 2011). Para dar conta, nesse processo, do papel, perfil e das relações entre os atores sociais e agentes de educação profissional o Plano se estruturou em três eixos fundamentais.

O primeiro eixo correspondeu à articulação institucional que tinha como objetivo a construção e à consolidação de um novo enfoque metodológico e operacional da educação profissional. Contemplava as seguintes dimensões: i. foco na demanda de mercado de trabalho e no perfil da população alvo, visando atender a demanda do setor produtivo; ii. direito do cidadão produtivo à educação básica (fundamental e média), iii. desenvolvimento integrado de habilidades básicas, específicas e/ou de gestão do trabalhador, por meio de cursos, treinamentos, etc. e, iv. atenção à diversidade social, econômica e regional da População economicamente ativa (PEA), buscando promover a igualdade de oportunidades nos programas de qualificação e no acesso ao mercado de trabalho. (BRASIL, 2001c).

O segundo destacava o avanço conceitual, que visava construir e consolidar uma nova institucionalidade da educação profissional no País, promovendo à inserção e a contribuição do PLANFOR no quadro das políticas públicas. Esse processo implicou a mobilização e fortalecimento de novos atores sociais, consolidando e integrando a rede de educação profissional. O Plano, ainda, tinha a função de atender às demandas de qualificação de outros programas sociais públicos, especialmente aqueles destinados à população pobre, sujeita a exclusão social, à discriminação, à violência e ao risco social. (JORGE, 2009). 
O terceiro eixo destacava o apoio dados à sociedade civil, ou seja, à promoção de ações de qualificação do trabalhador, incluindo não só cursos, mas assessorias, extensão, pesquisas e estudos. Estas ações visavam atender grupos vulneráveis, ou seja, pessoas com dificuldades de acesso ao trabalho e as alternativas de qualificação profissional, por razões de seletividade do mercado de trabalho. (BRASIL, 2001c).

Cabe ressaltar que o PLANFOR considerava o planejamento das ações de qualificação profissional tendo como foco principal a demanda do mercado, dando ênfase à empregabilidade, na qual é desenvolvida a ideia de que cabe ao trabalhador se qualificar e se tornar empregável para uma diversidade maior de postos de trabalho, colocando como responsabilidade do próprio trabalhador a sua inserção e permanência no mercado de trabalho. (JORGE, 2009).

A qualificação dos trabalhadores é vista como primordial para se atingir o desenvolvimento econômico e social ${ }^{19}$ de um país ou região, entretanto as ações destinadas à qualificação prezam primordialmente por articularem um conjunto de habilidades e competências destinadas a excelência na execução e/ou prestação de serviços, fatores necessários ao mercado de trabalho sem tomar as devidas providências para inserir ações de qualificação que busquem desenvolver os aspectos sociais (educação cidadã e emancipatória) dos trabalhadores para que em conjunto possam promover a inclusão social.

Coaduna com essa ideia o que se apresenta no Relatório da UNESCO, o qual aponta que a procura da educação para fins econômicos não parou de crescer em grande parte dos países e as comparações internacionais destacam a importância do capital humano ${ }^{20}$ para esse fim, e, portanto, do investimento educativo para a produtividade. Há uma estreita ligação entre o progresso técnico e a qualidade da intervenção humana, bem como da necessidade de formar agentes econômicos aptos a utilizar as novas tecnologias e que revelem um comportamento inovador. Novas aptidões são requeridas e o sistema educativo deve dar conta desse propósito, não somente assegurando os anos de educação formal ou profissional, mas formando pesquisadores inovadores e técnicos de alto nível. (UNESCO, 1998).

\footnotetext{
${ }^{19}$ Grifo nosso.

${ }^{20}$ Grifo nosso
} 
Tendo em vista as evoluções tecnológicas, ocorridas nos últimos anos se faz necessária que o trabalhador adquira competências evolutivas articuladas com 0 saber-fazer atualizado.

Esta revolução irreversível não aceita as rotinas nem as qualificações obtidas por imitação ou repetição e verifica-se que se dá uma importância cada vez maior aos investimentos ditos imateriais, como formação, à medida que a "revolução da inteligência" produz os seus efeitos. (UNESCO, 1998, p. 71).

Conforme já abordado o PNQ surgiu na sequencia ao PLANFOR, estabelecendo novas diretrizes para utilização dos recursos do Fundo de amparo ao Trabalhador (FAT), destinados à qualificação social e profissional do trabalhador, entendida como um conjunto de políticas que estão entre a fronteira do trabalho e da educação em articulação com as políticas de desenvolvimento. (SAUL \& FREITAS, 2007).

O PNQ estabelece os seus objetivos na Resolução nํㅜ 333/2003 do Conselho Deliberativo do Fundo de Amparo ao Trabalhador (CODEFAT).

De acordo com 0 art. $2^{\circ} \circ \mathrm{PNQ}$ deve contribuir para promover a integração das políticas e para a articulação das ações de qualificação social e profissional, em conjunto com outras políticas e ações vinculadas ao emprego, trabalho, renda e educação, deve promover o acesso dos trabalhadores à qualificação, visando contribuir para:

i. A formação integral (intelectual, técnica, cultural e cidadã).

ii. Aumento da probabilidade de obtenção de emprego e trabalho decente e da participação em processos de geração de oportunidades de trabalho e de renda, reduzindo os níveis de desemprego e subemprego.

iii. Elevação da escolaridade dos trabalhadores, através da articulação com as políticas públicas de educação, em particular com a Educação de Jovens e Adultos.

iv. Inclusão social, redução da pobreza, combate à discriminação e diminuição da vulnerabilidade das populações. 
v. Aumento da probabilidade de permanência no mercado de trabalho, reduzindo os riscos de demissão e as taxas de rotatividade ou aumento da probabilidade de sobrevivência do empreendimento individual e coletivo;

vi. Elevação da produtividade, melhoria dos serviços prestados, aumento da competitividade e das possibilidades de elevação do salário ou da renda. (BRASIL, 2001c).

O PNQ surge com o propósito de estabelecer um desvio na trajetória da política pública de qualificação profissional no país, partindo de observações críticas ao PLANFOR, tais como: pouca sinergia entre a política pública de qualificação profissional e as demais políticas públicas de trabalho e renda (seguro desemprego, intermediação de mão-de-obra, informações sobre o mercado de trabalho etc.); desarticulação desta em relação às políticas públicas de educação; fragilidades das Comissões Estaduais e Municipais de Trabalho ${ }^{21}$, enquanto espaços de participação efetiva da sociedade; baixo grau de institucionalidade da rede nacional de qualificação profissional; ênfase em cursos de curta duração, voltados ao tratamento das habilidades e competências específicas, comprometendo uma ação de caráter educativo mais integral; fragilidade no sistema de planejamento, monitoramento e avaliação do PLANFOR. (SAUL; FREITAS, 2007).

Embasado em outra ótica, mais humanista e menos mercadológica, o PNQ foi formulado visando à inclusão social e a redução das desigualdades sociais; alicerçado na ideia de que o crescimento pelo trabalho, emprego e renda, deve ser ambientalmente sustentável e redutor das desigualdades regionais; e proporcionar à promoção e à expansão da cidadania e o fortalecimento da democracia. (MTE, 2003).

A política pública de qualificação profissional por meio do PNQ sofreu uma reorientação que envolveu uma série de dimensões, tais como: política, conceitual, institucional, pedagógica, ética e operacional. Em primeiro lugar, a qualificação profissional foi afirmada na perspectiva do direito social, devendo ser orientada para

\footnotetext{
${ }^{21}$ As Comissões Estaduais de Emprego - organismos tripartites e paritários, com representação do governo, empresariado e trabalhadores de cada Estado, responsáveis pelo levantamento das demandas locais de qualificação, assim como realizavam um trabalho de acompanhamento da execução dos cursos ofertados (BRASIL, 2001c).
} 
o desenvolvimento sustentável, a inclusão social e a consolidação da cidadania. (SAUL; FREITAS, 2007).

Acrescenta-se, ainda que o Plano buscou a integração entre à qualificação profissional e o Sistema público de emprego, trabalho e renda e às políticas públicas de educação e de desenvolvimento. Visando a concertação social e uma maior qualidade de vida aos trabalhadores.

Em referência às teorias aportadas neste estudo e aos planos de qualificação executados entre os anos de 1996 a 2011, PLANFLOR e PNQ, verifica-se que as ações abarcaram o final de um século e início de outro, período em que transformações econômicas, políticas e sociais ocorreram, porque o mundo está sempre em crescente mutação. Foi possível concluir que o primeiro plano estava centrado nas demandas de uma minoria, alicerçadas nas concepções de competência e habilidades para atender ao mercado de trabalho e não as necessidades de desenvolvimento do trabalhador; por outro lado, no segundo Plano houve uma tentativa de correção e de incremento da qualificação, buscando dessa vez a inclusão de ações mais abrangentes para a formação integral dos. A proposta era de uma formação/qualificação social, na qual os preceitos de uma educação cidadã fossem prioritários, no entanto, percebe-se que apesar desse incremento o PNQ manteve ainda muitas das diretrizes e objetivos do PLANFOR.

Verifica-se que houve um distanciamento entre as intenções do PNQ e as possibilidades de sua realização, pois a formulação conceitual desse plano não se materializou, devido à incapacidade das políticas públicas de educação profissional operar mudanças efetivas que possibilitem romper com a circularidade virtuosa que reitera a dominação do capital sobre o trabalho (SILVA, 2009). Outro fator, de acordo com Peixoto (2008) foi que não houve, em nenhum dos planos, propostas de acompanhamento dos egressos. Neste sentido os objetivos relativos à elevação da escolaridade, à educação continuada e à inclusão social ficaram comprometidos.

Os programas complementares que foram instituídos concomitantes ao $P N Q$, tais como: Projovem, Escola de Fábrica, Consórcio da Juventude, Juventude Cidadã, atualização da Lei do estágio e a reorganização da Lei da Aprendizagem, não tiveram uma organização unificada, foram ações setorizadas que atenderam algumas características da formação dos trabalhadores, mas não conseguiram se 
constituir num conjunto de ações articuladas capazes de enfrentar um dos principais desafios dos trabalhadores brasileiros: a baixa escolaridade. (CASTIONI, 2010).

Observa-se que ambos os planos continuaram reproduzindo as assimetrias anteriores existentes, sem superar os históricos traços de heterogeneidade e desigualdade do mercado de trabalho brasileiro.

O PNQ vigorou de 2003 a 2011 sendo substituído pelo Programa Nacional de Acesso ao Ensino Técnico e Emprego (PRONATEC) que será tratado mais amiúde no próximo subcapítulo. O quadro 1, abaixo, sistematiza um resumo do histórico da educação profissional detalhados neste subcapítulo:

Quadro 1 - Educação Profissional Brasileira

\begin{tabular}{|l|l|}
\hline \multicolumn{1}{|c|}{ ANO } & \multicolumn{1}{|c|}{ SíNTESE DA EDUCAÇÃO PROFISSIONAL NO BRASIL } \\
\hline 1800 & Adoção do modelo de aprendizagem dos ofícios manufatureiros. \\
\hline 1808 & Criação do Colégio das Fábricas. \\
\hline 1906 & $\begin{array}{l}\text { Início do ensino técnico; elaboração do Projeto de promoção do ensino prático industrial, } \\
\text { agrícola e comercial. }\end{array}$ \\
\hline 1909 & $\begin{array}{l}\text { Instituição do Decreto no } 7.566 \text { de 23 de setembro de 1909 que oficializou a educação } \\
\text { profissional brasileira; Criação de 19 “Escolas de Aprendizes Artífices” (CEFET's). }\end{array}$ \\
\hline 1927 & Sanção do Projeto que previa o oferecimento obrigatório do ensino profissional no país. \\
\hline 1930 & Escolas superiores para formação de recursos humanos para o processo produtivo. \\
\hline 1934 & Expansão do ensino industrial. \\
\hline 1937 & $\begin{array}{l}\text { Instituição do ensino técnico, profissional e industrial na Constituição de 37 e da Lei 378, } \\
1937 \text { transformava as Escolas de Aprendizes e Artífices em Liceus Profissionais. }\end{array}$ \\
\hline 1940 & Surgimento do Sistema S. \\
\hline 1941 & Reforma Capanema que remodelou todo o ensino no país. \\
\hline 1942 & Instituição do Decreto no 4.127, de 25 de fevereiro de 1942; criação do SENAI. \\
\hline 1946 & $\begin{array}{l}\text { Criação do Serviço Nacional de Aprendizagem Comercial (SENAC), do Serviço Social do } \\
\text { Comércio (SESC) e Serviço Social da Indústria (SESI). }\end{array}$ \\
\hline $1956-61$ & Governo de JK - formação de profissionais orientados para o desenvolvimento do país. \\
\hline 1963 & Implementação do Programa intensivo de preparação de mão-de-obra (PIPMO). \\
\hline 1971 & Instituição da Lei de Diretrizes e Bases da Educação Brasileira - LDB, no. 5.692. \\
\hline
\end{tabular}




\begin{tabular}{|c|c|}
\hline 1978 & $\begin{array}{l}\text { Instituição da Lei no } 6.545 \text {, Escolas Técnicas Federais são transformadas em Centros } \\
\text { Federais de Educação Tecnológica (CEFETs). }\end{array}$ \\
\hline 1990 & Criação do SENAR, SENAT, SESCOOP e SEBRAE. \\
\hline 1994 & $\begin{array}{l}\text { Sanção da Lei o } 8.948 \text {, que dispõe sobre a instituição do Sistema Nacional de } \\
\text { Educação Tecnológica; o MTE lançou o Programa de Reciclagem Profissional. }\end{array}$ \\
\hline 1996 & $\begin{array}{l}\text { Implementação do PLANFOR. Vigorando até o ano 2002; Instituição da segunda LDB, } \\
\text { Lei } 9.394 \text { que dispõe sobre a Educação Profissional. }\end{array}$ \\
\hline 1997 & $\begin{array}{l}\text { Instituição do Decreto } 2.208 / 1997 \text { regulamenta a educação profissional e cria o } \\
\text { Programa de Expansão da Educação Profissional (PROEP). }\end{array}$ \\
\hline 1999 & $\begin{array}{l}\text { Retoma-se o processo de transformação das Escolas Técnicas Federais em Centros } \\
\text { Federais de Educação Tecnológica, iniciado em } 1978 .\end{array}$ \\
\hline ANO & SÍNTESE DA EDUCAÇÃO PROFISSIONAL NO BRASIL \\
\hline 2004 & O Decreto 5.154/2004 permite a integração do ensino técnico ao ensino médio. \\
\hline 2005 & $\begin{array}{l}\text { Lançamento da primeira fase do Plano de Expansão da Rede Federal de Educação } \\
\text { Profissional e Tecnológica, com a construção de } 64 \text { novas unidades de ensino. }\end{array}$ \\
\hline 2006 & $\begin{array}{l}\text { O Decreto } 5.773 \text { dispõe sobre educação superior e cursos superiores de graduação e } \\
\text { sequenciais; o Decreto } 5.840 \text { institui O PROEJA; lançado o Catálogo Nacional dos } \\
\text { Cursos Superiores de Tecnologia; realização da } 1 \text { a Conferência Nacional de Educação } \\
\text { Profissional e Tecnológica. }\end{array}$ \\
\hline 2007 & $\begin{array}{l}\text { Lançamento da segunda fase do Plano de Expansão da Rede Federal de Educação } \\
\text { Profissional e Tecnológica. }\end{array}$ \\
\hline 2008 & Lançamento do Catálogo Nacional dos Cursos Técnicos; criação dos Institutos Federais. \\
\hline 2009 & $\begin{array}{l}\text { Criação do Sistema Nacional de Informações da Educação Profissional e Tecnológica } \\
\text { (SISTEC); criação da Rede e-TEC para fomentar a oferta de cursos técnicos à distância. }\end{array}$ \\
\hline 2011 & Sanção da Lei no 12.513 de 26 de outubro de 2011 que institui o PRONATEC. \\
\hline 2012 & $\begin{array}{l}\text { Resolução } n^{0} 6 \text {, de } 20 \text { de setembro, do Conselho Nacional de Educação (CNE), que } \\
\text { estabelece as diretrizes curriculares nacionais para a educação profissional técnica de } \\
\text { nível médio. }{ }^{22}\end{array}$ \\
\hline
\end{tabular}

Fonte: elaborado pela autora, 2016

As políticas públicas de educação profissional implementadas no País ao longo do século $X X$ até o início do século $X X I$ apesar de representar um grande avanço em termos de abrangência e ampliação de programas, projetos e ações,

\footnotetext{
22 Um dos aspectos mais salientados desta resolução diz respeito à articulação da educação profissional com o ensino médio, algo que havia sido explicitamente abolido na gestão presidencial de Fernando Henrique Cardoso. Em relação às modalidades de oferta, são reiteradas as seguintes categorias: i) articulada (integrada ou concomitante); e ii) subsequente, o que também vem ao encontro de tais interesses e possibilidades.
} 
focou-se no atendimento de interesses do capital, prevalecendo à formação para o mercado de trabalho, com pouca ênfase na educação profissional para a emancipação dos sujeitos.

\subsubsection{A Educação profissional brasileira na atualidade}

A Política Pública para a educação profissional se estabeleceu nos campos econômicos e do trabalho, da educação e do desenvolvimento, entendendo que era necessário preparar um contingente enorme de pessoas para dar conta das demandas oriundas do setor produtivo. Foi concebida compreendendo ações e serviços de formação, orientação, certificação, entre outros, por meio da atuação de atores públicos e privados. Abrange a identificação e elaboração de demandas, definição de base institucional e de financiamento e articulação de responsabilidades, processos de planejamento, monitoramento e avaliação. Normalmente segue as Resoluções e Recomendações da Organização Internacional do Trabalho (OIT). (IVO et. al., 2013).

Essas recomendações, geralmente, abarcam questões relativas ao ensino técnico e profissional, orientação profissional, formação de jovens e adultos e formação continuada, introduzida pela UNESCO, buscando articular aprendizagem, formação profissional e políticas públicas de emprego.

Seguindo essas referencias o Brasil propôs na LDB as normas que regem a educação profissional e tecnológica. De acordo com o Artigo № 39 da LDB a educação profissional e tecnológica, no cumprimento dos objetivos da educação nacional, integra-se aos diferentes níveis e modalidades de educação e às dimensões do trabalho, da ciência e da tecnologia. (BRASIL, 1996b).

Os cursos de educação profissional e tecnológica poderão ser organizados por eixos tecnológicos, possibilitando a construção de diferentes itinerários formativos, observadas as normas do respectivo sistema e nível de ensino, podendo abranger os seguintes cursos:

I. Formação inicial e continuada ou qualificação profissional.

II. Educação profissional técnica de nível médio.

III. Educação profissional tecnológica de graduação e pós-graduação. 
A educação profissional será desenvolvida em articulação com o ensino regular ou por diferentes estratégias de educação continuada, em instituições especializadas ou no ambiente de trabalho. $\mathrm{O}$ conhecimento adquirido por meio dessa modalidade, inclusive os adquiridos no local de trabalho, poderão ser objeto de avaliação, reconhecimento e certificação para prosseguimento ou conclusão de estudos.

A formação profissional, no País, ocorre em escolas de Educação Profissional, públicas e privadas, que ofertam cursos de formação inicial e continuada (FIC), cursos Técnicos e Tecnológicos, destinados a atender pessoas desempregadas e/ou que busquem uma formação/qualificação para seu aperfeiçoamento profissional. Neste contexto, essas escolas, possuem a responsabilidade de gerar saberes coletivos e flexíveis ${ }^{23}$, sintonizados com as novas bases e novas formas de organização produtiva, fundados na produção e difusão de inovações de cunho tecnológico, marca fortemente presente nos últimos séculos.

O programa que integra a política de educação profissional é o Programa Nacional de Acesso ao Ensino Técnico e Emprego (PRONATEC), criado em 2011 pelo governo federal e disseminado nacionalmente como principal ação de qualificação para estimular o processo de formação da força de trabalho no país. O programa estabelece os ajustes educativos, tecnológicos e profissionalizantes que as políticas educacionais nacional e regional devem adotar, integrar e articular para atender aos requerimentos demandados pelos setores produtivos. Como objetivos principais, o PRONATEC estabelece o seguinte:

I - expandir, interiorizar e democratizar a oferta de cursos de educação profissional técnica de nível médio presencial e a distância e de cursos e programas de formação inicial e continuada ou qualificação profissional; II - fomentar e apoiar a expansão da rede física de atendimento da educação profissional e tecnológica;

III - contribuir para a melhoria da qualidade do ensino médio público, por meio da articulação com a educação profissional;

IV - ampliar as oportunidades educacionais dos trabalhadores, por meio do incremento da formação e qualificação profissional;

V - estimular a difusão de recursos pedagógicos para apoiar a oferta de cursos de educação profissional e tecnológica.

\footnotetext{
${ }^{23}$ Grifo nosso.
} 
VI - estimular a articulação entre a política de educação profissional e tecnológica e as políticas de geração de trabalho, emprego e renda. (Incluído pela Lei oㅜ 12.816, de 2013) (BRASIL. Lei oㅜ 12.513, 2011d).

As ações do PRONATEC tem sua gestão na Secretaria de Educação Profissional e Tecnológica (SETEC) do MEC. Porém, prevê em sua execução a articulação entre diversos ministérios atendendo a demandas específicas. Na prática a articulação do Programa tem trazido à tona o quanto é difícil a execução desses processos em um sistema burocrático.

O foco dessa política, de acordo com o artigo primeiro, é a ampliação da oferta e do acesso à educação profissional e ao emprego. Dentre os objetos propostos, destaca-se o Bolsa-Formação, que se articula com diversos programas sociais no sentido de ampliar massivamente a oferta de cursos de formação inicial e continuada e a qualificação de trabalhadores. Pode-se verificar no Art. $4^{\circ}$ que o PRONATEC será desenvolvido por meio das seguintes ações, sem prejuízo de outras:

I - ampliação de vagas e expansão da rede federal de educação profissional e tecnológica;

II - fomento à ampliação de vagas e à expansão das redes estaduais de educação profissional;

III - incentivo à ampliação de vagas e à expansão da rede física de atendimento dos serviços nacionais de aprendizagem;

IV - oferta de bolsa-formação, nas modalidades:

a) Bolsa-Formação Estudante; e

b) Bolsa-Formação Trabalhador;

V - financiamento da educação profissional e tecnológica;

VI - fomento à expansão da oferta de educação profissional técnica de nível médio na modalidade de educação a distância;

VII - apoio técnico voltado à execução das ações desenvolvidas no âmbito do Programa;

VIII - estímulo à expansão de oferta de vagas para as pessoas com deficiência, inclusive com a articulação dos Institutos Públicos Federais, Estaduais e Municipais de Educação; e

IX - articulação com o Sistema Nacional de Emprego

$X$ - articulação com o Programa Nacional de Inclusão de Jovens PROJOVEM, nos termos da Lei no 11.692, de 10 de junho de 2008. (Incluído pela Lei no 12.816, de 2013). (BRASIL. Lei no 12.513, 2011d).

Segundo análise do IPEA (2015e) o MEC, nos últimos anos, vem ampliando a sua atuação na educação técnica e profissional, particularmente, com a expansão da rede federal e o acordo feito com o Sistema S e pela instituição do Pronatec em 
2011, que foi o principal instrumento de financiamento da expansão da educação técnica e profissional do país no quadriênio 2012- 2015.

Conforme análise oficial do IPEA (2015e) a execução orçamentária no âmbito da educação profissional e tecnológica foi a que teve o maior crescimento entre os três níveis de ensino. Em grande medida, esse desempenho foi devido à ação de apoio à formação profissional e tecnológica, que operacionaliza a concessão de bolsas-formação do PRONATEC, cujos dispêndios em 2013 mais que duplicaram o montante executado no ano anterior, conforme mostra a figura 7.

Figura 6 - execução financeira do PRONATEC (2012-2013)

\begin{tabular}{|c|c|c|c|}
\hline Açoies & 2012 & 2013 & Variaçāo (\%) \\
\hline Expansāo e reestruturaçāo da Rede federal de educaçao profisssional e tecnológica & 869.495 .100 & 825.039 .222 & $-5,1$ \\
\hline Modernização da rede pública não federal de educação profissional e tecnológica & 371.616 .366 & 192.941 .086 & $-48,1$ \\
\hline Funcionamento das instituiç̄ies federais de educação profissional e tecnológica & 1.785 .902 .539 & 1.762 .636 .860 & $-1,4$ \\
\hline Apoio à formação profissional e tecnológica & 1.311 .798924 & 2.753 .473 .656 & 109,9 \\
\hline Fomento ao desenvolvimento da educação profisssional & 112.888 .234 & 101.594 .691 & $-10,0$ \\
\hline Educaçāo Profissional e Tecnológica a Distância (e-TEC Brasil) & 86.557 .060 & 50.886 .425 & $-41,2$ \\
\hline Assistência ao educando da educação profissional & 166.221 .568 & 236.834 .194 & 42,5 \\
\hline Capacitaçäo de recursos humanos da eduç̧̧ৃo profissional & 12.762 .233 & 16.902 .496 & 32,4 \\
\hline Total & 4.718242026 & 5.940308 .630 & 25,9 \\
\hline
\end{tabular}

Fonte: IPEA/2015

As metas divulgadas para a educação em nível técnico revelam o quão ambicioso foi o Programa; buscou-se alcançar, até 2014, a marca de 5 (cinco) milhões de matrículas em cursos técnicos (IPEA, 2011e). No entanto verificando, junto ao MEC, a execução do Programa até 2014 percebeu-se que as metas não foram atingidas nem de longe, conforme verifica-se na figura 8 abaixo: 
Figura 7 - PRONATEC/MEC (2011-2014)

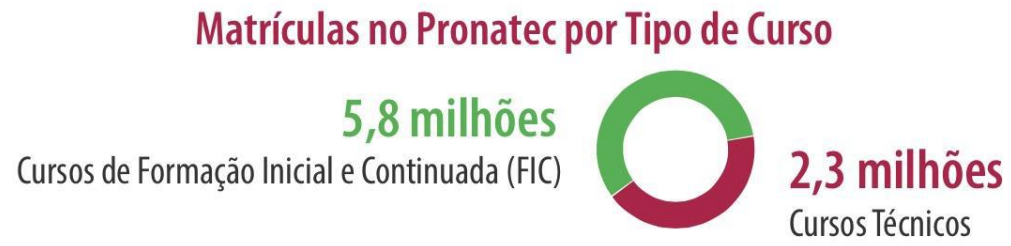

Fonte: $\mathrm{MEC} / 2015$

O PRONATEC congrega seis grandes ações: Brasil Profissionalizado ${ }^{24}$, expansão da rede federal de educação profissional científica e tecnológica (EPCT), período 2012-2015 (116 novas escolas, no entanto a meta era de 208); Acordo de gratuidade com o Sistema $\mathrm{S}^{25}$; Bolsa-Formação ${ }^{26}$ (cursos de formação inicial e continuada (FIC) ou de qualificação profissional e cursos técnicos de nível médio), essas duas modalidades de cursos totalizaram cerca de 8,1 milhão de matrículas até 2014; Rede e-Tec Brasil ${ }^{27}$ (em 2013, foram ofertadas 137 mil novas vagas) e Fies Técnico e Empresa ${ }^{28}$. Outro ponto destacado pelo MEC foi a oferta de 220 cursos técnicos e de mais de 600 cursos FIC em aproximadamente 4.300 munícipios brasileiros. (BRASIL, 2014g).

O Programa Nacional de Integração da Educação Profissional com a Educação Básica na Modalidade de Educação de Jovens e Adultos (Proeja),

\footnotetext{
${ }^{24}$ O programa Brasil Profissionalizado, instituído em 2007, transfere recursos às UFs no intuito de expandir e modernizar a rede de educação profissional e tecnológica, de modo a ampliar o acesso à formação técnica integrada ao ensino médio, por meio da articulação entre formação geral e educação profissional, tendo-se por referência os arranjos produtivos locais e regionais.

${ }^{25}$ Em junho de 2008 foram firmados protocolos de compromisso entre MEC, MTE, MF, CNC e CNI para a aplicação de $2 / 3$ da receita compulsória líquida do Senai, SENAC na oferta de vagas gratuitas em cursos técnicos e de formação inicial e continuada para estudantes de baixa renda ou trabalhadores, até 2014. Além disso, 1/3 dos recursos destinados a serviços sociais pelo Sesi e pelo SESC deveria ser aplicado em atividades de educação, sendo que metade deles deveria ser destinado a financiar atividades gratuitas.

${ }^{26}$ De acordo com o Guia PRONATEC de Cursos FIC (4a edição), havia 646 cursos em 2013, enquanto que o Catálogo Nacional de Cursos Técnicos registrava outros 220 cursos.

${ }^{27}$ A Rede e-Tec Brasil tem por finalidade a ampliação da oferta nacional de educação profissional e tecnológica, na modalidade à distância. Para tanto, são desenvolvidas ações voltadas à formação de recursos humanos, produção de material didático, aquisição de equipamentos e laboratórios e ao apoio à realização dos cursos. (BRASIL, 2014g).

${ }^{28}$ Além de criar a Bolsa-Formação, a Lei no 12.513 ampliou o alcance do fundo de financiamento ao estudante do ensino superior, que passa a ser chamado de Fies, abrindo mais duas linhas de financiamento: o Fies Técnico e o Fies Empresa.
} 
instituído em 2006 e o programa Mulheres Mil, relacionam-se com a educação profissional. O primeiro trata-se de iniciativa de integração entre o aumento da escolaridade formal e a formação profissional específica já o programa Mulheres Mil se destina ao segmento feminino em situação de vulnerabilidade social. (BRASIL, 2014g).

O público-alvo das ações de qualificação são os estudantes do ensino médio da rede pública, inclusive da educação de jovens e adultos; os beneficiários dos programas federais de transferência de renda, e os trabalhadores, sobretudo os que estão em condição de beneficiário do seguro desemprego.

As opções de qualificação, constantes do catálogo de cursos são os técnicos com carga horária mínima de 800h e os de Formação Inicial e Continuada (FIC), com carga horária mínima de 160 horas. A oferta destes cursos está sob a responsabilidade da Rede Federal de Educação Profissional e Tecnológica, do Sistema S e das Redes Privadas de Educação. (BRASIL, 2011d).

Conforme pesquisa no site do MEC, para 2016 o PRONATEC Busca a melhoria da qualidade dos cursos e a expansão da oferta de educação profissional, a articulação com o Reconhecimento de saberes $^{29}$ e com construção de Itinerários formativos ${ }^{30}$, para estimular o jovem e o trabalhador retomarem sua trajetória nos estudos e consequentemente aumentarem sua escolaridade e seu nível de formação profissional. (BRASIL, 2016h).

As instituições de formação profissional movimentam volumes consideráveis de recursos voltados, principalmente, para oferta de cursos FIC, na sua maior parte,

\footnotetext{
${ }^{29} \mathrm{O}$ Art. 41 da Lei de diretrizes e Bases da Educação Nacional define que "O conhecimento adquirido na educação profissional, inclusive no trabalho, poderá ser objeto de avaliação, reconhecimento e certificação para prosseguimento ou conclusão de estudos".

30 Em 2016, as instituições ofertantes do PRONATEC poderão estruturar os seus cursos profissionalizantes por meio de itinerários formativos. Desta forma, amplia-se a oportunidade para que jovens e trabalhadores concluintes de cursos do programa possam dar continuidade em sua trajetória de formação profissional. Os estudantes que concluírem com êxito cursos profissionalizantes associados a itinerários formativos poderão se beneficiar com acesso aos cursos técnicos, aproveitando os conhecimentos adquiridos previamente e concluindo em menor tempo uma nova formação. Da mesma forma, os concluintes dos cursos técnicos poderão, ao ingressar em cursos tecnológicos de graduação, ter reconhecidos parte do que estudaram na formação técnica. A integração entre os itinerários formativos e o reconhecimento de saberes trará mais flexibilidade para - estudante e aumentará a atratividade da educação profissional, possibilitando ao jovem e trabalhador iniciar a sua formação num curso de qualificação profissional e avançar até a conclusão de um curso profissional de nível superior.
} 
com caráter meramente de qualificação profissional, mantendo-se metodologias ultrapassadas para atender as demandas atuais.

\begin{abstract}
Há, porém um nó crítico que pode inviabilizar a estratégia de qualificar grandes contingentes de trabalhadores: a inexistência de metodologia e de conteúdo programático adequados às necessidades do mercado e à demanda dos trabalhadores por um processo educativo que não fique circunscrito apenas à qualificação profissional, e que lhes possibilite a continuidade dos estudos (ALVES; VIEIRA, 1995, p.131).
\end{abstract}

Percebe-se que a maior preocupação do Programa é oferecer mão de obra para um sistema produtivo em constante expansão e carente de pessoal qualificado, atrelado à geração de emprego e renda, no entanto, não há uma preocupação efetiva com a formação desses trabalhadores (cidadã e emancipatória), por meio de conteúdos transversais às ocupações, que possibilitem uma formação completa, que atenda às necessidades educativas e sociais dos sujeitos.

O PRONATEC considera o número de matrículas efetuadas como indicador de efetividade do Programa, entretanto, a relação de efetividade/eficiência deveria estar atrelada à inclusão social dos trabalhadores, à elevação da escolaridade e à continuidade do processo de ensino aprendizagem ao longo da vida. Entende-se que apenas matricular não agrega valor a um processo de mudança que se pretende com a execução desse programa: "garantir trabalhadores mais preparados e qualificados para o mercado de trabalho, possibilitando agregar valor ao sistema produtivo do País". (BRASIL, 2001d). Isso sem se quer falar na educação para a inclusão social e desenvolvimento humano que não se apresenta nos objetivos do Programa, o que o distancia enquanto desdobramento da Política Nacional de Qualificação.

É urgente que o setor público recupere sua capacidade de planejar e articular as ações na área da formação/qualificação e desenvolvimento profissional, para propor Políticas públicas que permitam uma formação cidadã ao trabalhador. Essa política deve ter por objetivo incentivar a criação de metodologias educacionais motivadoras, capazes de, simultaneamente, introduzir o trabalhador nas questões de educação geral e de cidadania, e de qualificá-lo para o exercício de uma profissão.

A qualificação profissional está presente nos debates dos governos e empresários como um dos mais importantes ingredientes da valorização profissional 
do trabalhador e propulsor de empregabilidade, no entanto, comumente está restrita ao atendimento das necessidades do mercado cada vez mais competitivo e excludente.

Nas transformações do trabalho no mundo capitalistas o conhecimento científico e tecnológico se constitui principal insumo para o processo produtivo. A educação/qualificação/formação profissional revela-se como fator de crescimento, competitividade, qualidade e produtividade, elementos necessários a um mercado mundializado.

A divisão capitalista do trabalho é fonte de alienações, que estropia o trabalhador, favorece o desenvolvimento de habilidades parciais, extinguindo um mundo de instintos e capacidades (MARX, 1985). A necessidade de aumentar produção e a competividade e dominar mercados, comumente, faz com que as ações de formação/qualificação profissional voltem-se especificamente ao atendimento das demandas de mercado sem se preocupar com as demandas dos trabalhadores por uma formação ao longo da vida.

A própria LDB tem como eixo estruturante a formação para o mundo do trabalho, o que é bem mais amplo que a visão neoliberal de formação do "capital humano" para o mercado de trabalho. Está fundamentada na relação trabalho/educação, visando dotar o trabalhador de habilidades e competências para acompanhar as evoluções científicas e tecnológicas do mundo do trabalho ${ }^{31}$. Os currículos devem estar baseados nessas premissas de modo a promover a qualificação do trabalhador para sua inserção produtiva e cidadã ${ }^{32}$ (BRASIL, 1996b) percebe-se que esta última em menor escala nos currículos de educação profissional.

Uma oferta de formação/qualificação profissional de qualidade poderá evitar que os processos de flexibilização, terceirização e outros decorrentes do processo de modernização produtiva levem à precarização do emprego e das ocupações. Para atingir os requisitos profissionais, necessários ao ingresso e à permanência no mercado de trabalho em transformação é essencial o aumento do nível educacional dos trabalhadores.

\footnotetext{
${ }^{31}$ Grifo nosso.

${ }^{32}$ Grifo nosso.
} 
Além do "saber-fazer" demanda-se dos trabalhadores o "saber ser" e o "saber agir", entendidos como capacidades de se portar criativamente e eficazmente frente às situações que se apresentem como problema e àquelas que exijam respostas rápidas e inovadoras. (IVO et. al. 2013, p. 385).

Existe, ainda, outro importante e negligenciado desafio: "as carências educacionais das gerações hoje na faixa dos 30 anos que passaram pelo sistema escolar dos anos 1970-2000, quando as expectativas de escolaridade eram muito inferiores às atuais, já de si insatisfatórias". (IPEA, 2015e, p.230). Essas pessoas constituem, atualmente, a força de trabalho, política e social do País e encontram dificuldades significativas para exercerem plenamente seu papel social e para usufruir de seus direitos sociais e políticos. (IPEA, 2015e).

Outro fator apontado pelo IPEA (2015) é que as políticas educativas destinadas às gerações futuras apresentam resultados ínfimos o que não corroborará para a formação dos trabalhadores do futuro. "Frequentemente se alega que tais programas costumam dar poucos resultados e que os métodos e os instrumentos se mostram ineficientes e custosos, mas quase nada se tem feito para mudar esse quadro". (IPEA, 2015e, p. 231).

Os modelos de educação profissional que utilizam como parâmetros a produção e a organização do trabalho (modelo taylorista/fordista) estabelecem uma qualificação padronizada, de modo que os trabalhadores estejam aptos para o desempenho de funções específicas e operacionais "sob esta ótica a qualificação é restrita ao posto de trabalho e não a um conjunto de atributos inerentes ao trabalhador". (SAUL; FREITAS 2007, p. 15). Assim, exige-se um conjunto de conhecimentos e habilidades inerentes ao cargo, sem apresentar nenhuma conotação sociocultural.

No modelo por competências preza-se a capacidade do trabalhador para mobilizar, articular e colocar em ação valores, conhecimentos (saber) e habilidades (capacidade de executar algo relacionado ao trabalho) e atitudes (ética, convivência participativa, qualidade, iniciativa e criatividade), necessários para o desempenho eficiente e eficaz de atividades requeridas pela natureza do trabalho. (OIT, 2002).

As distintas concepções de qualificação para o mercado são construídas mantendo-se o vínculo com o trabalho, à produção social, o desenvolvimento 
econômico, a educação e a formação profissional, que expressam diferentes visões e interesses de vários grupos sociais. Fazem parte desse arcabouço as noções presentes no campo da economia, da educação e da sociologia do trabalho têm-se assim como sinônimo a preparação de capital humano. Essa visão baseia-se na Teoria do capital humano ${ }^{33}$, na qual o homem é visto apenas como um recurso criador e produtivo ${ }^{34}$, estando presentes a cultura do adestramento ${ }^{35}$, ou seja, as ações de qualificação profissional são restritas à atividade produtiva e ao desenvolvimento de competências inerentes aos postos de trabalho. (SAUL; FREITAS, 2007).

Essa visão está alicerçada na concepção do saber fazer, adquiridas por meio de cursos ou experiência profissional; do saber ser, que diz respeito aos comportamentos nas relações sociais de trabalho, capacidade de inciativa, comunicação, inovação e mudança e assimilação de novos valores de qualidade, produtividade e competitividade; e, o saber agir, ou seja, tomar decisões acertadas diante de eventos novos e diversificados. (SAUL; FREITAS, 2007).

Percebe-se que a educação profissional no Brasil está ancorada nessas visões, uma vez que as principias ações de qualificação estão intrinsicamente ligadas às ocupações ( $\mathrm{CBO}$ ), aos postos de trabalho e as noções de competências. Ou Seja, qualifica-se para preparar pessoas para uma atividade privativa e especializada, quer seja de cunho operacional, técnico ou superior, visando o desenvolvimento de habilidades básicas, específicas e de gestão requeridas pelo mercado.

Tem-se nessa atuação uma qualificação genérica e universal voltada à produtividade, ao aumento de capital, ao atendimento das novas tecnologias e do mercado. Preparam-se pessoas para uma atuação individualizada, nessa lógica, quem tem maior grau de especialização e capacidade de empregar suas competências para garantir o lucro das empresas, buscar melhores salários e sucesso profissional fica em vantagem. Entretanto, quem está na contramão desse

${ }^{33}$ Teoria do capital humano (Theodore Schutz e Frederic H. Harbison, 1974) baseia-se em um processo de formação e incremento de número de pessoas que possuem as habilidades, a educação e a experiência indispensável para o desenvolvimento político, econômico de um país.

${ }^{34}$ Grifo nosso.

${ }^{35}$ Grifo nosso. 
processo não consegue entrar e/ou manter-se no mercado de trabalho, neste sentido a formação/ qualificação torna-se um processo de exclusão social? Ou por outro lado se for formativa para a cidadania pode contribuir para a inclusão social?

Essas são algumas das inquietações desta pesquisa, as quais pelo confronto da teoria e a práxis buscar-se-á as respostas ao longo deste trabalho.

\subsubsection{ATUAL POLÍTICA DE QUALIFICAÇÃO PROFISSIONAL EM TURISMO}

A educação em turismo e hospitalidade deveria prioritariamente trabalhar os preceitos da cidadania, tendo em vista que o turismo proporciona o contato entre seres humanos, cujas culturas, hábitos e modo de vida são diferenciados assim é preciso que tanto o turista, quanto os trabalhadores do setor, compreenda essas diferenças para que haja respeito entre ambos, e, para que a troca de experiência seja realmente válida e enriquecedora.

Outro ponto que merece atenção na educação em turismo é que esta seja emancipatória, que permita transformar o conhecimento-regulação em conhecimento-emancipatório (SANTOS, 2011), ou seja, ir para além do ensino técnico e operacional a caminho de uma educação que torne os sujeitos livres e independentes para agir nas situações de trabalho e em sociedade.

\footnotetext{
O turismo é uma combinação complexa de inter-relacionamentos entre produção e serviços, em cuja composição integram-se uma prática social com base cultural, com herança histórica, a um meio ambiente diverso, cartografia natural, relações sociais de hospitalidade, troca de informações interculturais. O somatório desta dinâmica sociocultural gera um fenômeno, recheado de objetividade/subjetividade [...] (MOESCH, 2001, 9).
}

Verifica-se que este fenômeno ocorre em meio às relações sociais produzidas pelos sujeitos (turistas, trabalhadores, moradores), deste modo, deve-se promover uma troca entre pares que seja positiva para ambos. Entende-se que a educação profissional tem um relevante papel nessa construção.

Os serviços turísticos são assegurados pelos moradores locais, uma parcela da comunidade que trabalha no setor, que junto aos empregadores fornecem uma contribuição essencial à vida turística, entretanto não se pode entender os recursos sociais, culturais e naturais de uma localidade como mercadorias, e sim como relações humanas. (MOESCH, 2015). 
É perceptível que a região das Américas tem um grande potencial para continuar impulsionando o desenvolvimento do turismo para que se constitua em um instrumento de inclusão social que possibilite a geração de empregos e melhor qualidade de vida da população dentro de um marco de sustentabilidade. (OMT, 2015).

O Brasil dispõe de enormes potencialidades para absorção de maior parcela do mercado mundial do turismo. Hoje representa apenas $0,6 \%$ do total das viagens mundiais (aproximadamente 6 milhões de turistas estrangeiros). (OMT, 2015).

Cabe indagar quais são os principais gargalos que o país enfrenta no setor do Turismo que impedem o seu efetivo desenvolvimento e a maior maturidade nos serviços prestados. As pesquisas apontam as questões infraestruturais, a falta de competitividade onde se incluem os indicadores que recaem sobre a qualidade dos serviços, que é influenciada de forma significativa pela qualidade da formação dos trabalhadores do setor. (BRASIL, 2015).

Com a crescente valorização do conhecimento, as habilidades exigidas do profissional de Turismo tornaram-se mais complexas e múltiplas, tais como: a utilização do raciocínio lógico, crítico e analítico; a capacidade de expressão em seu idioma e em idiomas estrangeiros; o manejo das tecnologias de informação e comunicação e de outros recursos tecnológicos; a percepção da necessidade constante de aperfeiçoamento profissional, de acompanhar a evolução científica e tecnológica; a capacidade de trabalhar em equipes multidisciplinares e intersetoriais, fatores que possibilitam agir criativamente em diferentes contextos de atuação profissional e ampliar a qualidade do acolhimento dos destinos turísticos.

Observando essas tendências o Ministério do Turismo (MTur) propôs diferentes ações de qualificação, constante de uma agenda de prioridades que iniciou nos anos de 2004 e desenvolveu-se durante uma década. Com intuito de avaliar esse processo, lançou em 2015 as Diretrizes Nacionais para Qualificação em Turismo (DNQT) importante decisão para começar a se pensar na estruturação de uma política de qualificação para o setor diante dos desafios até então não atendidos o que representou um primeiro passo visando estruturar de forma assertiva o papel do ente público na qualificação profissional em turismo. 
Os estudos que compuseram a DNQT, promoveram uma reflexão acerca das ações de qualificação empreendidas, pelo MTur desde sua criação, por meio de programas e projetos que foram executados em parceria com instituições públicas e privadas, permitiu constatar que houveram ações significativas, mas, a maioria apresentou pouca sinergia e resultados excessivamente tímidos, senão errôneos. Percebeu-se pouquíssimos esforços para atender as necessidades dos trabalhadores, de modo, a ofertar formações profissionais que trabalhassem na perspectiva do desenvolvimento humano e social, que propiciassem desenvolver carreiras, aumentando a empregabilidade e diminuindo a rotatividade inerente ao setor. (MOESCH, 2014).

Implantar uma política de formação/qualificação profissional que promova o conhecimento emancipador e não apenas operacional é uma condição indispensável para que se possa buscar a inclusão efetiva desses trabalhadores no setor. Observa-se que nos últimos anos houve uma crescente oferta de cursos na área de Turismo e Hospitalidade em todos os níveis - Ensino Profissional (cursos Formação Inicial e Continuada (FIC), Cursos Técnicos) e Ensino Superior (Tecnológico, Graduação, Pós-Graduação e Sequenciais). Apesar desse crescimento e do aumento de vagas de trabalho, geradas pela dinâmica do mercado das cidades sedes dos megaeventos esportivos, os empregadores reclamam da carência de trabalhadores qualificados (Brasil, 2015a). Isso mostra que a oferta de cursos disponível, em que pese o grande investimento público, não está permitindo a inclusão social dos trabalhadores. De acordo o MEC, os cursos na área de Turismo e Hospitalidade oferecidos no Brasil estão distribuídos conforme a quadro 2 abaixo: 
Quadro 2 - Cursos na área de Turismo e Hospitalidade

\begin{tabular}{|c|c|}
\hline \multicolumn{1}{|c|}{ Nível } & Quantidade \\
\hline Graduação/tecnológico & 472 \\
\hline Técnico / Profissionalizante & $33.752^{36}$ \\
\hline FIC & $252.210^{37}$ \\
\hline Especialização & 59 \\
\hline Sequencial & 1 \\
\hline Mestrado & 12 \\
\hline Doutorado & 3 \\
\hline
\end{tabular}

Fonte: Elaborado pela autora - dados do MEC (2016)

Como apontado anteriormente, os benefícios da qualificação e do aperfeiçoamento profissional serão alcançados se o governo e a iniciativa privada oferecerem em parceria programas de educação profissional que promovam não só a aplicação de conteúdos técnicos e operacionais, mas, sobretudo que proporcionem uma qualificação ao longo da vida, como forma de buscar uma educação libertadora e emancipatória.

[...] educação que desvestida de roupagem alienada e alienante, seja uma força de mudança e de libertação. A opção, por isso, teria de ser também, entre uma educação para a domesticação, para alienação, e uma educação para a liberdade. Educação para o hoeme-objeto ou educação para o homem-sujeito (FREIRE, 1977, p. 36).

Retomando o que apresenta o Ministério da Educação, os cursos de educação profissional e tecnológica poderão ser organizados por eixos tecnológicos, possibilitando a construção de diferentes itinerários formativos, observadas as normas do respectivo sistema e nível de ensino, podendo abranger os seguintes cursos: i. (FIC) ou qualificação profissional; ii. educação profissional técnica de nível médio e, iii. educação profissional tecnológica de graduação e pós-graduação.

O quadro 3 abaixo sistematiza a oferta de formação profissional no eixo Turismo-hospitalidade e lazer:

\footnotetext{
${ }^{36}$ Quantidade de matrículas efetuadas de 2011 a 2016 nos cursos Técnicos do eixo Turismo, Hospitalidade e Lazer por todos os parceiros demandantes junto ao MEC.

${ }_{37}$ Quantidade de matrículas efetuadas de 2011 a 2016 nos cursos FIC do eixo Turismo, Hospitalidade e Lazer por todos os parceiros demandantes junto ao MEC, incluindo o MTur.
} 
Quadro 3 - Modalidades e categorias de cursos

\begin{tabular}{|c|c|}
\hline NÍVEL & CATEGORIA \\
\hline \multicolumn{2}{|c|}{ Profissionalizante } \\
\hline FIC & $\begin{array}{l}\text { Camareira, garçom, barman, mensageiro, } \\
\text { recepcionistas, maitre, copeiro, área de } \\
\text { limpeza e manutenção, confeiteiro, padeiro, } \\
\text { auxiliar de cozinha, línguas estrangeiras, } \\
\text { auxiliares administrativos, libras, } \\
\text { organizador de eventos, sommelier etc. }\end{array}$ \\
\hline Técnico & $\begin{array}{l}\text { Cozinha, hospedagem, guiamento, eventos, } \\
\text { agência de viagem, lazer e serviços de } \\
\text { restaurantes e bares. }\end{array}$ \\
\hline Tecnológico & $\begin{array}{l}\text { Área de eventos, de gastronomia, gestão de } \\
\text { turismo, gestão desportiva e de lazer e de } \\
\text { hotelaria. }\end{array}$ \\
\hline \multicolumn{2}{|r|}{ Superior } \\
\hline Graduação & $\begin{array}{l}\text { Pesquisa, planejamento, gestão, direção, } \\
\text { marketing, meio ambiente, lazer. }\end{array}$ \\
\hline Pós-graduação & $\begin{array}{l}\text { Aprofundamento dos conhecimentos para } \\
\text { pesquisa e investigação científica, docência, } \\
\text { planejamento, gestão. }\end{array}$ \\
\hline
\end{tabular}

Fonte: Elaborada pela autora, 2016

A formação inicial e continuada ou qualificação profissional será desenvolvida em articulação com o ensino regular ou por diferentes estratégias de educação continuada, em instituições especializadas ou no ambiente de trabalho. O conhecimento adquirido por meio dessa modalidade, inclusive os adquiridos no local de trabalho, poderão ser objeto de avaliação, reconhecimento e certificação para prosseguimento ou conclusão de estudos.

Em relação aos cursos FIC do Eixo Tecnológico de Turismo, Hospitalidade e Lazer, compreendem tecnologias relacionadas aos processos de recepção, viagens, eventos, serviços de alimentação, bebidas, entretenimento e interação. Abrange os processos tecnológicos de planejamento, organização, operação e avaliação de produtos e serviços inerentes ao turismo, hospitalidade e lazer. As atividades compreendidas neste eixo referem-se ao lazer, relações sociais, turismo, eventos e gastronomia, todas integradas ao contexto das relações humanas em diferentes espaços geográficos e dimensões socioculturais, econômicas e ambientais. A pesquisa, disseminação e consolidação da cultura, ética, relações interpessoais, domínio de línguas estrangeiras, prospecção mercadológica, marketing e 
coordenação de equipes são elementos comuns deste eixo. São traços marcantes da organização curricular desses cursos: ética, educação ambiental, normas técnicas e de segurança, historicidade, empreendedorismo, redação técnica, além de capacidade de trabalhar em equipes, com inciativas, criatividade e sociabilidade. (BRASIL, 2012h).

A carga horária desses cursos perfaz 160 a 400 horas e atende preferencialmente pessoas desempregadas que busquem uma qualificação ou requalificação para se inserirem no mercado de trabalho.

Há um consenso nacional de que a formação para o trabalho exige hoje níveis cada vez mais altos de educação básica, geral, não podendo esta ficar reduzida à aprendizagem de algumas habilidades técnicas, o que não impede o oferecimento de cursos de curta duração voltados para a adaptação do trabalhador às oportunidades do mercado de trabalho, associados à promoção de níveis crescentes de escolarização regular. Finalmente, entende-se que a educação profissional não pode ser concebida apenas como uma modalidade de ensino, mas deve constituir educação continuada, que perpassa toda a vida do trabalhador.

A educação profissional e técnica de nível médio do eixo Turismo, Hospitalidade e Lazer compreende os cursos de Técnico de Agenciamento de viagem, Técnico em Cozinha, Técnico em eventos, Técnico em Guia de turismo, Técnico em hospedagem, Técnico em lazer e Técnico em serviços de restaurantes e bares. A carga horária mínima é de 800 horas. (BRASIL, 2015J).

A educação profissional tecnológica de graduação, no eixo Lazer e Desenvolvimento Social, Turismo e Hospitalidade compreende atividades visando ao aproveitamento do tempo livre e ao desenvolvimento pessoal, grupal e comunitário. As atividades de lazer incluem, entre outras, as de esportes, recreação, entretenimento, folclore, arte e cultura. As de desenvolvimento social incluem as atividades voltadas para a reintegração e inclusão social, para a participação em grupos e na comunidade, e para a melhoria da qualidade de vida nas coletividades. A gestão de programas desta área é planejada, promovida e executada de forma participativa e mobilizadora, com enfoque educativo e solidário. Concretiza-se em torno de questões sociais estratégicas, como as de prática físico-desportiva, de fruição artístico-cultural, de recreação e entretenimento, de grupos de interesse, de 
saúde, de educação, de alimentação, de habitação, de qualidade da vida urbana, de educação ambiental, de infância e juventude, de terceira idade, de consumo e consumidor, de oferta de serviços públicos, de trabalho e profissionalização, de geração de emprego e renda, de formação de associações e de cooperativas e, de voluntariado. Os cursos ofertados são eventos, gastronomia, gestão de turismo, gestão desportiva e de lazer e hotelaria com carga horária de 2400 horas. (BRASIL, 2011).

Paralelo à educação profissional em Turismo existe a Educação Superior em Turismo com cursos de graduação que são oferecidos aos candidatos egressos do ensino médio e, para a continuidade dos estudos, os cursos de pós-graduação lato sensu e stricto sensu e cursos sequenciais. $\mathrm{Na}$ área de Turismo e Hospitalidade esta modalidade de ensino possui importância relevante. Devido ao seu caráter transdisciplinar, o turismo tem relação com diversas áreas tais como lazer, transportes, artes, meio ambiente, saúde, marketing, desenvolvimento social, entre outras, exigindo um profissional completo e capaz de desenvolver a atividade de forma dinâmica, criativa e sustentada. A principal finalidade destes cursos é o preparo de pessoas para atuar no planejamento, gestão, pesquisa e docência na área. Têm como foco o turismo como fenômeno econômico e social, cultural e ecológico e os processos específicos da gestão dos meios de hospedagem e dos serviços de alimentação.

Em que pese as modalidades de educação em Turismo existentes no País, sob a custodia do MEC, especificamente quanto a educação profissional, existe a atuação do MTur, que teve seu início ainda na Empresa Brasileira de Turismo (EMBRATUR) com o "Programa Nacional de Municipalização Turismo" (PNMT) ${ }^{38}$, por meio da capacitação/qualificação dos agentes Multiplicadores nacionais, estaduais e dos monitores municipais, para a orientação dos diversos segmentos da comunidade com vistas à constituição do Conselho Municipal do Turismo e do Fundo Municipal do Turismo.

${ }^{38}$ O Programa Nacional de Municipalização do Turismo - PNMT foi um Programa desenvolvido e coordenado pela EMBRATUR, mediante a adoção da metodologia da Organização Mundial do Turismo - OMT, adaptada à realidade brasileira, com o propósito de implementar um novo modelo de gestão da atividade turística, simplificado e uniformizado, para os Estados e Municípios, de maneira integrada, buscando maior eficiência e eficácia na administração da atividade turística, de forma participativa. 
O programa Embarque Nessa, criado pelo Ministério do Esporte e Turismo em parceria com a EMBRATUR foi destinado à conscientização de alunos do ensino fundamental para a necessidade de valorização e proteção do patrimônio natural e cultural do Brasil, além de ressaltar a importância do turismo para o desenvolvimento social e econômico local.

A partir de janeiro de $2003 \mathrm{com}$ a criação do Ministério do Turismo e a elaboração de três Planos Nacionais de Turismo, ao longo desses 13 anos, o tema qualificação sempre apareceu como fator determinante para alavancar o setor.

A promoção da Qualificação Profissional consta como um objetivo da Política Nacional do Turismo (PNT), expresso no inciso XIX, do artigo $5^{\circ}$ da Lei Geral do Turismo "promover a formação, o aperfeiçoamento, a qualificação e a capacitação de recursos humanos para a área de turismo, bem como a implementação de políticas que viabilizem a colocação profissional no mercado de trabalho". (BRASIL. Lei no 11771, 2008) e no art. 11 que trata da criação do Comitê Interministerial de Facilitação Turística com a finalidade de compatibilizar a execução e a consecução das metas do PNT com as demais políticas públicas, de forma que os planos, programas e projetos das diversas áreas do Governo Federal venham a incentivar: inciso VIII "a formação, a capacitação profissional, a qualificação, o treinamento e a reciclagem de mão de obra para o setor turístico e sua colocação no mercado de trabalho" e inciso XII "a geração de emprego". (BRASIL. Lei no 11771, 2008).

Percebe-se que ao se inserir na Legislação máxima do Turismo a qualificação profissional o MTur teve a intenção de dar prioridade ao tema, assim, ao longo desses quase 13 anos muitas ações com esse intuito foram executadas, mas, o objetivo primordial, que se configura na inserção dos profissionais no mercado de trabalho, premissa muito válida para a inclusão social, não foi efetivado.

O tema qualificação é recorrente, também, nos três Planos Nacionais de Turismo, no primeiro que correspondeu ao período 2003-2007, diagnosticou a questão como um problema a ser solucionado: "qualificação profissional deficiente dos recursos humanos do setor, tanto no âmbito gerencial quanto nas habilidades específicas operacionais". (PNT, 2003 p.17). Assim, a qualificação se constitui no Macro Programa 5: Programa de Qualificação Profissional, cujo objetivo visava à promoção da capacitação, da qualificação e da requalificação dos agentes atuantes 
em toda cadeia produtiva do turismo, nos diversos níveis hierárquicos, tanto do setor público quanto do setor privado visando ocupar os novos postos de trabalho gerados. O PNT apontou, ainda que o Turismo "poderá, por meio de programas de qualificação profissional, elevar a qualidade da oferta turística nacional, fator essencial para inserir o país competitivamente no mercado internacional". (BRASIL, 2003 p.9).

A implementação do Programa Nacional de Qualificação Profissional e Empresarial do Turismo tinha como objetivo induzir a melhoria da qualidade e da segurança dos serviços turísticos, por meio da qualificação profissional e empresarial continuada, com base nas necessidades quantitativas e qualitativas do setor privado e dos trabalhadores do segmento, visando a aumentar a satisfação do turista e a competitividade dos destinos.

Nesse processo estados, municípios e as associações do setor receberam apoio para elaboração e execução de planos/projetos de qualificação e certificação, totalizando um montante $\mathrm{R} \$ 32$ milhões, no período de 2003 a 2005. (BRASIL, 2006q).

Avançou-se também na normalização em turismo, com a publicação de 35 Normas Técnicas Brasileiras, e na criação do Sistema Brasileiro de Certificação ocupacional em Turismo, em particular no que tange à aferição do desempenho do profissional por ocupação ou por competência.

Paralelo a esse Programa o Departamento de Programas Regionais de Desenvolvimento do Turismo, responsável pelo Programa Nacional de Desenvolvimento do Turismo (PRODETUR) apoiava a elaboração de levantamentos diagnósticos, programas de capacitação com os seus respectivos projetos para execução de ações de qualificação profissional e empresarial nos Polos turísticos.

O segundo PNT (Uma viagem de inclusão) esteve vigente de 2007-2010 apresentando uma série de estratégias e medidas para o estímulo ao mercado interno. Foram propostas que pretendiam abrir as portas do turismo nacional para que todos os brasileiros pudessem se beneficiar; seja como turista, como empregado, como prestador de serviço, como empresário. Por meio de cursos de qualificação profissional, da geração de novos empregos, da incorporação das camadas sociais de baixa renda como clientes do setor, seja pela adoção de 
políticas segmentadas para aposentados, trabalhadores e estudantes. O objetivo era estimular o turismo interno e abrir novas portas para a inclusão social.

Alocou na qualificação um importante papel para a organização dos 65 destinos turísticos, distribuídos em todo o território nacional, dentro de um padrão internacional de mercado. "O fomento ao aumento da competitividade dos destinos turísticos e a melhoria da qualidade dos serviços ofertados devem ser prioridades por meio da qualificação profissional e incremento dos produtos e serviços em todos os elos da cadeia produtiva do setor". (PNT, 2007 p.30).

O PNT, por meio de um diagnóstico, apresentou informações sobre o Programa Nacional de Qualificação Profissional e Empresarial que investiu $R \$ 15,3$ milhões para atender 46 mil pessoas no País, em parceria com estados, municípios, iniciativa privada e organizações não governamentais, consolidando ações desenvolvidas no período 2003-2005. Ações de certificação também foram priorizadas, tendo sido desenvolvidas 19 normas brasileiras para o Turismo de Aventura em 2006. O Programa Alimento Seguro no Turismo, em parceria com a Agência Nacional de Vigilância Sanitária (ANVISA) e a Associação Brasileira de Bares, Restaurantes e Similares (ABRASEL) qualificou 5.632 manipuladores de alimentos e atendeu 662 empresas. Foram apoiados também diversos projetos voltados à formação de jovens para o turismo, tendo como meta alcançar 140 mil alunos de escolas públicas e 11 mil jovens trabalhadores ou em situação de vulnerabilidade social. (PNT, 2007).

Em detrimento a essas ações o MTur reconhece que apesar de todos os esforços e dos resultados obtidos nos últimos anos, as ações de qualificação profissional ainda enfrentam entraves para alcançar a excelência no atendimento e na prestação de serviços, uma vez que a mão de obra empregada no turismo apresenta baixa escolaridade, baixa remuneração e alta rotatividade. Destaca-se, ainda a baixa percepção da qualificação profissional como investimento pelos empresários. (PNT, 2007).

Com o objetivo de assessorar tecnicamente o Conselho Nacional de Turismo na identificação e discussão das questões fundamentais do setor e propor ações para resolução dos problemas e entraves, necessários à consecução da Política Nacional do Turismo, foram instituídas Câmaras Temáticas, integradas por 
representantes das entidades membros do Conselho Nacional. Durante a primeira gestão do MTur, foram instaladas 10 Câmaras Temáticas, entre essas, a Câmara Temática de Qualificação Profissional.

O PNT aponta que "ações de qualificação e certificação profissional, bem como de certificação de empreendimentos turísticos, são também fundamentais para a estruturação dos destinos turísticos em padrão de qualidade internacional". (PNT, 2007, p.27).

Com base nos resultados das ações do MTur nos últimos anos, foram projetados os resultados esperados para 2007 a 2010, conforme a figura 9 abaixo.

Figura 8 - Resultados

\begin{tabular}{|l|r|r|r|r|}
\hline \multicolumn{1}{|c|}{ DESCRIÇÃO } & 2007 & 2008 & 2009 & 2010 \\
\hline $\begin{array}{l}\text { Investimentos em Infraestrutura } \\
\text { MTur (Em R } \$ \text { bilhões empenhados) }\end{array}$ & 1,32 & 1,39 & 1,46 & 1,56 \\
\hline $\begin{array}{l}\text { Pessoas } \\
\text { qualificadas }\end{array}$ & 51.340 & 56.474 & 62.121 & 68.334 \\
\hline $\begin{array}{l}\text { Profissionais } \\
\text { certificados }\end{array}$ & 1.960 & 2.254 & 2.592 & 2.981 \\
\hline $\begin{array}{l}\text { Empreendimentos } \\
\text { certificados }\end{array}$ & 290 & 2.899 & 3.334 & 3.834 \\
\hline
\end{tabular}

Fonte PNT, 2007

Apesar do planejamento realizado pelo MTur não foi possível verificar se essas metas foram cumpridas e qual o impacto delas no desenvolvimento dos trabalhadores e consequentemente do turismo, pois não houve 0 efetivo acompanhamento das ações.

No PNT (2007-2010) o Macro Programa Qualificação dos Equipamentos e Serviços Turísticos foi estruturado em três programas: Programa de Normatização do Turismo; Programa de Certificação do Turismo e, Programa de Qualificação Profissional. Esses programas estão apresentados conforme segue:

1. Programa de Normatização do Turismo - o conjunto de ações que integrou este programa objetivava criar e disponibilizar instrumentos normativos e regulamentadores que contemplassem requisitos mínimos de qualidade para produtos e serviços, que seriam cumpridos pelos prestadores de serviços turísticos, empreendimentos, equipamentos e profissionais de 
turismo. Propuseram-se a sistematização e o ordenamento dos instrumentos jurídicos relacionados ao turismo, de forma solucionarem conflitos e sobreposição de competências, tornando a legislação clara para a sua aplicação e reduzindo o excesso de burocracia na tramitação e nos procedimentos de aprovação dos projetos turísticos. Com base nessas normas, almejava-se o cadastramento, a classificação e a fiscalização dos prestadores de serviços turísticos, empreendimentos, equipamentos e profissionais de turismo, descentralizando a execução a órgãos conveniados, com vistas ao controle da qualidade dos produtos e serviços.

2. Programa de Certificação do Turismo - objetivava referenciar o mercado e consumidores nas suas decisões de compra, como também estimular a adoção de boas práticas, contribuindo para elevação do padrão de qualidade de serviços e produtos do segmento turístico, foi disseminado como ferramenta da busca pela excelência na prestação dos serviços. $O$ programa deveria apoiar a elaboração de normas técnicas brasileiras e estimular ações voltadas para a certificação de pessoas, produtos e empreendimentos. A certificação para o turismo teve um caráter voluntário e deveria ocorrer no âmbito do Sistema Brasileiro de Certificação. Teve também como função apoiar a certificação dos profissionais empregados, contribuindo para aumentar sua permanência nos postos de trabalho, assim como deveria possibilitar a inserção profissional. Ao mesmo tempo, que proporcionar o desenvolvimento das empresas apoiando ações de assistência técnica para a certificação.

3. Programa de Qualificação Profissional - inclui-se o conjunto de ações relativas à qualificação dos diversos tipos de profissionais que integravam a cadeia produtiva do turismo, bem como de ações voltadas à sensibilização da população local quanto à importância de sua participação para o sucesso e o desenvolvimento sustentável do turismo. A qualificação profissional deveria ter como premissa o atendimento à demanda quantitativa e qualitativa do mercado, relativamente aos setores, segmentos e destinos turísticos nas diversas regiões do País. Deveria 
ainda promover o desenvolvimento de metodologias e ferramentas pedagógicas apropriadas ao desenvolvimento de competências profissionais e a inserção profissional da população de baixa renda e dos jovens ao mercado de trabalho do setor, bem como de cursos, oficinas e seminários adequados à demanda identificada. O MTur coube coordenar o programa de forma sistêmica e integrada as demais instituições que atuaram na qualificação profissional dos diversos ramos das atividades prestadoras de serviços turísticos no País. A qualificação profissional para o turismo deveria estimular a educação continuada e a formação profissional articulada com o Plano de Desenvolvimento da Educação, do Ministério da Educação, e com os programas de qualificação profissional do Ministério do Trabalho e Emprego (PNT, 2007).

O Projeto Olá Turista lançado em agosto de 2009 foi uma das ações de qualificação implementadas pelo MTur, com a meta de capacitar 80 mil profissionais da cadeia produtiva do turismo, por meio de cursos de inglês e espanhol, a distância, voltados para recepcionistas, telefonistas, garçons, balconistas, taxistas, guias de turismo, artesãos, policiais e outros profissionais da cadeia que trabalhassem em contato direto com o público. (MTur, 2016)

Complementarmente, ao final de 2010 o MTur instituí o Programa Bem Receber Copa, com a meta de capacitar 306 profissionais do setor, objetivando: promover a qualidade dos serviços e produtos turísticos no Brasil; promover a qualificação e o aperfeiçoamento dos agentes atuantes em toda cadeia produtiva do turismo, nos diversos níveis hierárquicos, tanto do setor público quanto do setor privado; promover a qualidade e segurança dos serviços prestados ao turista; aprimorar a qualidade dos empreendimentos, equipamentos e produtos turísticos; aumentar a competitividade do turismo no mercado internacional; promover o aperfeiçoamento e qualificação da gestão empresarial, a melhoria da qualidade e da competitividade, a oferta de serviços responsáveis e seguros ao turista e a certificação de empreendimentos, equipamentos e produtos turísticos. (BRASIL, 2010r).

Cabe ressalvar que esses dois programas foram suspensos pela Portaria $\mathrm{n}^{\circ}$ 180, de 22 de setembro de 2011, devido às recomendações do Tribunal de Contas 
da União (TCU) quanto à possibilidade dos riscos ao erário advindos dos Projetos do Programa Bem Receber Copa. (BRASIL 2011s).

Com a eminência do Megaevento, o Ministério ao final de 2011 adotou o PRONATEC como programa prioritário para a qualificação profissional dos trabalhadores do setor, e instituiu o PRONATEC Turismo, que é objeto desta pesquisa.

O PNT 2013-2016 apresenta a qualificação como uma das estratégias para o fortalecimento e posicionamento do turismo a partir do Programa de Regionalização, por meio do apoio a ações de fortalecimento institucional, promovendo o planejamento, a qualificação e as práticas de cooperação entre os diferentes atores, públicos e privados, na busca da competitividade dos produtos turísticos nas regiões (PNT, 2013).

O Plano contempla a Ação: 6.3 Fomentar, regular e qualificar os serviços turísticos, que é composta, entre outras, pela ação 6.3.4 Capacitar e qualificar profissionais e gestores do setor de turismo por meio de ações relacionadas ao desenvolvimento de metodologias, conteúdos, ferramentas tecnológicas e pedagógicas para o aprimoramento e atualização das competências profissionais e do fomento à oferta de cursos de aperfeiçoamento em diferentes áreas do conhecimento. Prevê ainda o incentivo à formação de mão de obra para o primeiro emprego no setor, por meio da articulação com instituições públicas, em particular o Ministério da Educação e o Ministério do Trabalho e Emprego, de acordo com a demanda do mercado de trabalho do turismo. Tem como finalidade melhorar a qualidade dos serviços prestados ao turista e aumentar a empregabilidade e a competência dos profissionais por meio da qualificação. (PNT, 2013).

Já a ação 6.3.8 Qualificação profissional para melhoria da qualidade dos serviços a serem ofertados aos turistas que visitarão o país nos megaeventos buscou elevar a competitividade do país como destino turístico, por meio do PRONATEC Turismo, com objetivos de alcançar a melhoria da qualidade dos serviços ofertados aos turistas nas cidades sede da Copa do Mundo, seus entornos e em destinos turísticos consolidados nacional e internacionalmente, bem como as cidades sedes das Olímpiadas Rio 2016. 
Inicialmente o Programa foi dividido em três linhas de ação: (I) PRONATEC Copa na Empresa: destinados aos empresários e trabalhadores que atuam na cadeia produtiva do turismo. Com a finalidade de aperfeiçoar os profissionais que trabalham no setor, com cursos ministrados, preferencialmente, no próprio local de trabalho e em horários compatíveis com as atividades desempenhadas pelos colaboradores da empresa. O público em cada um dos municípios foi identificado pelas secretarias estaduais e municipais de Turismo, nas 12 cidades sede, juntamente com empresários e associações representativas do setor; (II) PRONATEC Copa: qualificação profissional para suprir necessidades de mão de obra do setor de turismo em cada um dos municípios participantes do PRONATEC Turismo; e (III) PRONATEC Copa Social: qualificação de jovens em situação de vulnerabilidade, visando promover sua inserção no mercado de trabalho do turismo, em parceria com o Serviço Social da Indústria (Sesi), no âmbito do Projeto Vira Vida.

Em $2015^{39}$ o PRONATEC Turismo foi reformulado e subdividido em quatro linhas de ação (BRASIL, 2015t):

i. PRONATEC Turismo Cidadão com vistas a atender à necessidade do setor de turismo por novos profissionais nas cidades contempladas pelo Programa (Anexo I), os cursos ofertados para esse público são os específicos do eixo Turismo, Hospitalidade e Lazer, por se tratar de uma formação inicial em algumas ocupações ligadas ao Turismo. Cujo objetivo é qualificar/preparar essas pessoas para inserção no mercado de trabalho do setor. As Secretarias estaduais, distrital e municipais de turismo devem realizar levantamento de demanda por novos profissionais junto aos empresários, associações, sindicatos, entre outros, de maneira a identificar os cursos e o quantitativo de vagas semestrais a serem pactuadas e ofertadas para 0 respectivo município, realizar contato prévio com ofertantes para pré negociar a demanda a ser atendida e verificar a necessidade de ajustes previamente às repactuações. (Anexo $B$ ).

\footnotetext{
${ }^{39}$ Portaria ำ 76, de 20 de maio de 2015 Estabelece regras e critérios de execução e monitoramento do Programa Nacional de Acesso ao Ensino Técnico e Emprego, no âmbito do Ministério do Turismo (PRONATEC TURISMO).
} 
2 PRONATEC Turismo na Empresa busca proporcionar cursos de aperfeiçoamento profissional aos trabalhadores do setor. Os cursos são em geral ministrados no próprio local de trabalho, na frequência e horários mais apropriados. As empresas, também, podem se organizar por representação $(A B I H, A B E O C$, ABRASEL, etc.) ou Sindicato e acordar o local do curso e as demais variáveis. As adesões ao PROGRAMA são voluntárias e poderão ser solicitadas por todas as empresas do setor: hospedagem, alimentação fora do lar, agenciamento de viagens, organização de eventos, entre outras. Serão aceitas também as solicitações de corporações de segurança pública de cursos para qualificação em idiomas, aplicados a aqueles que efetivamente terão contato com o fluxo turístico, de funcionários dos aeroportos, portos e terminais rodoviários interestaduais e internacionais. Os cursos disponíveis são os do eixo Turismo, Hospitalidade e Lazer e de outros eixos, como eixo Desenvolvimento Educacional e Social (idiomas), que contribuem para a melhoria da qualidade dos serviços prestados aos turistas, constantes do Anexo $\mathrm{C}$, desde que previamente identificada a demanda.

3 PRONATEC Turismo Social oferece oportunidade de qualificação profissional aos jovens egressos do Programa ViraVida ${ }^{40}$ em situação de vulnerabilidade social e para seus familiares, objetivando a sua inserção no mercado de trabalho do setor de turismo, nas cidades constantes do anexo IV. Podem ser parceiros à sua implementação o Ministério do Desenvolvimento Social e Combate à Fome, por intermédio das assistências sociais localizadas nos municípios contemplados, e o Conselho Nacional do SESI, bem assim as secretarias municipais de turismo. Os cursos ofertados serão os constantes do eixo Turismo,

\footnotetext{
${ }^{40}$ Programa, criado em 2008 pelo Conselho Nacional do SESI, que apoia meninos e meninas, com idade entre 16 e 21 anos, que sofreram violência sexual. Utilizando uma tecnologia de intervenção social, o programa oferece aos participantes a oportunidade de adquirir conhecimentos e desenvolver suas habilidades, para alcançarem a transformação em suas vidas por meio da inserção no mercado de trabalho. O objetivo do ViraVida é garantir os direitos e elevar a autoestima desses adolescentes e jovens, criando as condições necessárias para que alcancem a autonomia e o desenvolvimento pleno de suas vidas. O processo socioeducativo é desenvolvido em parceria com a Rede Nacional de Proteção das Crianças e Adolescentes e com as instituições que compõem o Sistema S (SESI, SENAI, SENAC,SESC, SEST, SENAT, SEBRAE e SESCOOP). Os cursos realizados combinam formação profissional e educação básica, além de atendimento psicossocial, médico e odontológico. Atualmente, o programa atende mais de cinco mil jovens no Brasil, em 26 cidades. Os cursos já implantados abrangem as áreas de Moda, Imagem Pessoal, Turismo e Hospitalidade, Gastronomia, Comunicação Digital, Administração, dentre outros.
} 
Hospitalidade e Lazer e, dos eixos de Gestão e Negócios, os quais constam do Anexo $\mathrm{V}$, desde que identificada a demanda pelo CN-SESI (Anexo D).

4 PRONATEC Turismo Desenvolvimento Local tem por objetivo promover a qualificação e o aperfeiçoamento de pessoas que exercem atividades produtivas associadas direta e indiretamente ao turismo, de forma a inserir esses produtores no Turismo. Podem ser ofertados os cursos dos eixos tecnológicos de controle de processos industriais, gestão e negócios, infraestrutura, produção alimentícia, produção artística, cultural e design, produção industrial, recursos naturais, constantes do Anexo E.

Em todas as linhas do Programa os demandantes adjuntos deverão realizar o levantamento prévio de demanda e negociar com os ofertantes para o alinhamento da necessidade e atendimento da demanda identificada.

Os critérios para inserção dos municípios para participar do PRONATEC TURISMO, foram os seguintes (Brasil, 2013x):

- sede da Copa, do seu entorno e alguns destinos turísticos brasileiros já consolidados no cenário nacional e internacional;

- integrantes das 303 regiões turísticas brasileiras;

- integrantes do PRONATEC, devem ter rede ofertante para que os cursos sejam executados;

- localizadas no entorno dos 12 parques nacionais priorizados pelo Ministério do Turismo, para estimular as visitas nos parques e o desenvolvimento do turismo nas cidades aos redores dos parques;

- patrimônio cultural mundial da humanidade (UNESCO), que tenham conjuntos urbanos e bens materiais tombados pelo IPHAN;

O Programa possuía como meta ofertar 240 mil vagas de cursos de qualificação profissional até a Copa do Mundo. No período de 2012-2015 foram matriculados, aproximadamente, 400 mil pessoas, sendo que desse total apenas 141 mil concluíram os cursos. Tais dados, per se, não permitem que se verifique se as práticas induzidas pelo programa na qualificação dos trabalhadores possibilitaram a geração de renda e emprego, bem como uma maior igualdade educacional e qualificação social, aspectos da inclusão social que deveriam ser inerentes aos atores envolvidos no processo de desenvolvimento turístico. Desse modo, após 
quase 5 anos de execução das ações ainda não se constata se houve um efetivo desenvolvimento do setor quer em nível de competitividade de destinos como em relação à melhoria da qualidade de vida dos profissionais.

Percebe-se que o MTur ao instituir os Planos Nacionais do Turismo ao longo desses quase 13 anos e o Programa Nacional de Qualificação Profissional e Empresarial do Turismo procurou pautar a qualificação como primordial para alavancar a competitividade dos destinos turísticos, gerar emprego e renda e possibilitar a inclusão social dos trabalhadores no setor, todavia os projetos primaram pelo desenvolvimento de competências e habilidades para atender as demandas do mercado e não as necessidades dos trabalhadores. Além disso, por falta de acompanhamento e avaliação não se sabe o resultado efetivo dessas ações, tampouco se esse processo possibilitou à agregação de valor ao trabalho no setor, ou seja, se foi efetivo para a inclusão social do trabalhador e, consequentemente para o desenvolvimento humanizador pelo Turismo.

Tendo em vista corrigir essas falhas e construir um novo caminho para a formação/qualificação em Turismo, o MTur, com intuito de institucionalizar uma política nacional de formação em Turismo elaborou em 2014 as Diretrizes Nacionais para a Qualificação em Turismo (DNQT), documento preliminar à política. (BRASIL, 5a). Em subsídio a esse documento foi preparada uma pesquisa, com o apoio da Universidade de Brasília, por meio do Centro de Excelência em Turismo, com a intenção de avaliar à qualificação profissional promovida pelo MTur, no período de 2003-2013, com objetivo de analisar para além das aparências expressas nos discursos oficiais e do setor empresarial sobre qualificação em turismo, utilizando-se do método da análise documental. (MOESCH et. al, 2014).

O recorte espacial dessa análise se constituiu de 67 documentos do MTur, referentes aos programas de qualificação, os quais tiveram convênios realizados com entidades que implantaram cursos de formação vocacional ${ }^{41}$, como o Sistema $S$ (SEBRAE, SENAC), IES, as entidades do trade (ABRASEL, ABIH, ABETA, IH,

\footnotetext{
${ }^{41} \mathrm{Na}$ década de 1980, alguns autores defendiam que o ensino em turismo poderia ser segmentado em dois tipos, o treinamento vocacional, que consiste no treinamento de pessoal da "linha de frente, de manutenção e de apoio", como algo mais prático e dinâmico para desenvolvimento de habilidades práticas. E em educação profissional que seria a educação pautada no ensino acadêmico, que se destina a ensinar conceitos, refletir e discutir sobre o planejamento e a tomada de decisões tanto no poder público quanto no poder privado. (TEIXEIRA, 2001).
} 
BRAZTOA, entre outros), conforme se apresenta no quadro 4. O recorte temporal se ateve aos últimos 10 anos, de 2003 a 2013, período de execução do programa de qualificação pública de turismo. As análises levaram em consideração questões como a formatação dos currículos, didáticas utilizadas, avaliações de processo, monitoramento, indicadores quantitativa/qualitativo, modalidade (educação profissional/formação vocacional), entre outras.

A análise interpretativa permitiu reunir e comparar as partes: elementos da problemática, contexto, autores, interesses, confiabilidade, natureza do texto e conceitos chave para fornecer uma interpretação coerente tendo em conta o questionamento inicial, reconstrução da textualidade da realidade. Como resultado obteve-se um documento preliminar contendo o panorama geral da qualificação e formação em turismo e hospitalidade.

Quadro 4 - Projetos de Qualificação analisados

\begin{tabular}{|l|l|}
\hline Bem Receber & Turismo de Aventura \\
\hline Qualifica Brasil & Aventura Segura \\
\hline ProJovem & $\begin{array}{l}\text { Programa de Qualificação à Distância } \\
\text { para o Desenvolvimento do Turismo }\end{array}$ \\
\hline Passaporte para o Mundo & Caminhos do futuro \\
\hline Bem Receber Copa & $\begin{array}{l}\text { Jornada para atualizações dos guias } \\
\text { de turismo }\end{array}$ \\
\hline Caminhos do Sabor & $\begin{array}{l}\text { Multiplicador de informações } \\
\text { turísticas }\end{array}$ \\
\hline Qualidade na Mesa & Trilha Jovem \\
\hline
\end{tabular}

Fonte: Relatório da Análise Documental (2014)

As análises dos documentos (Relatório da Análise Documental, 2014) levaram em consideração questões como a formatação dos currículos, didáticas utilizadas, avaliações de processo, monitoramento, indicadores quantitativa/qualitativo, modalidade (educação profissional/formação vocacional), entre outras.

A partir dos dados arrolados foi possível detectar as principais aprendizagens estabelecidas pelos programas implantados que buscou atender uma diversidade de 
públicos do sistema turístico e apoiar a organização setorial e fortalecimento da governança territorial por meio dos programas implantados e a inserção de jovens e adultos quando ocorreu uma articulação dos programas com as instituições de ensino.

Alguns dos principais problemas detectados, pela Análise Documental (2014) foi que a maioria dos projetos concentrou-se em métodos abstrato-formais, tiveram dificuldade de adaptação às realidades de cada localidade (diagnóstico). Houve baixa presença de modelos de avaliação, monitoramento e indicadores. Inexistência de critérios sobre vagas ofertadas e utilizadas; inexistência de orientações sobre cargas horárias em relação à tipologia de formação e fragilidade dos critérios de avaliação da qualidade pedagógica dos projetos analisados.

O estudo possibilitou uma crítica do processo de implementação do programa de qualificação do MTur, salientando que houve pouca clareza quanto à definição dos papéis entre os atores sociais e o MTur, causando dispersão de recursos e superposição de ações; concentração de ações em determinadas entidades; baixa integração dos programas de qualificação e demais programas de formação em cada território (Sistema S e Educação Formal); pouca ênfase na elevação da escolaridade; ausência de indicadores de avaliação externa; falta de monitoramento e revisão de ações de forma contínua; inexistência de uma perspectiva de educação continuada; desarticulação do ensino da educação profissional existente entre o MTur, nos IFs e Sistema S; baixa qualidade pedagógica dos cursos; ausência de conteúdos mínimos e de carga horária mínima, consequentemente baixa carga horária média dos cursos (formação vocacional) e valorização de pedagogia ativa em detrimento de uma pedagogia problematizadora. (MOESCH, 2014).

Outro fator relatado foi a desarticulação da Política de Qualificação do MTur com a Política Nacional de Qualificação do MTE e diálogo com o MEC ocorrendo esvaziamento do papel educativo e formativo dos programas propostos, pois muitos destes restringiram-se a uma preparação de um saber-fazer aos trabalhadores para o âmbito do paradigma fordista de qualificação, quando vive-se desafios bem mais complexos no campo do turismo e hospitalidade na atualidade. A figura 10 abaixo aponta como se estabeleceu nos últimos anos a política de qualificação em turismo. 
Figura 9 - Política Nacional de Qualificação em Turismo

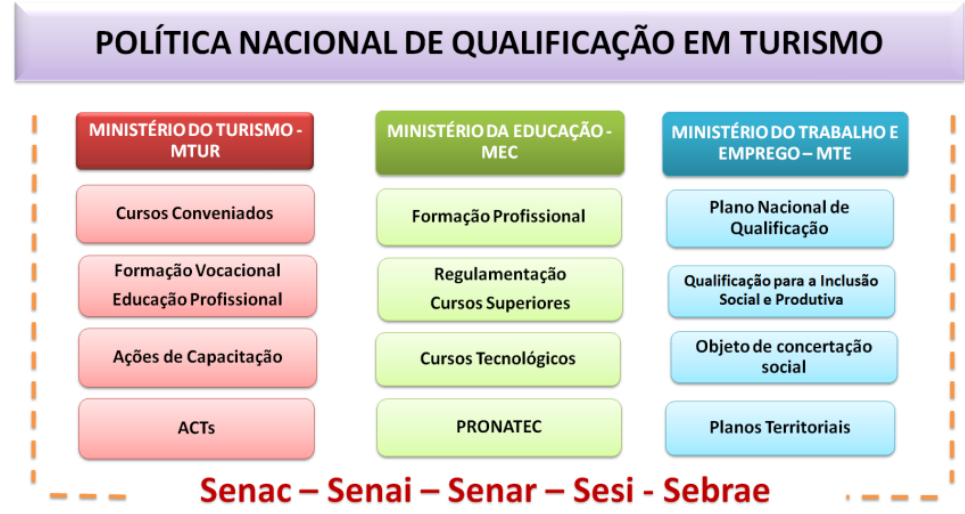

Fonte: Relatório de análise documental (Moesch, 2014).

Verifica-se que a educação profissional vigente hoje, por meio do PRONATEC $^{42}$ e do PRONATEC Turismo ${ }^{43}$, está composta por ações pontuais e descontínuas, os cursos ofertados atenderam a nichos específicos do mercado, apesar de que alguns representantes do setor compreendem que essas ações não atenderam as suas demandas, conforme apontado nas DNQT's, 2015.

A constituição do Programa por meio da oferta de um cardápio de cursos FIC e Técnicos surgiu da capacidade da oferta, ou seja, as instituições ofertantes, tais como os Institutos Federais e o Sistema S, propuseram apenas cursos já formatados e disponibilizados no rol das suas ações de educação profissional, compondo assim - Guia PRONATEC de cursos FIC do MEC e o Catálogo Nacional de Cursos Técnicos. Deste modo, as ações de qualificação profissional não se preocuparam em atender as demandas dos trabalhadores do setor.

A articulação no Programa foi extremamente custosa, uma vez que houve uma enorme dificuldade em articular as demandas do mercado (essa foi a única forma de levantamento de demandas utilizadas pelo MTur, recorrer as Secretarias de Turismo que articularam com o trade as suas necessidades por qualificação) com

\footnotetext{
${ }^{42}$ Programa no âmbito do MEC que atua com a qualificação profissional por meio da Formação Inicial e Continuada (FIC), Cursos Técnicos e Tecnológicos do Eixo Turismo, Hospitalidade e Lazer, no qual todos os Ministérios participantes do Programa podem solicitar vagas nos cursos desse eixo.

${ }^{43}$ Programa instituído pelo MTur em parceria com o MEC no qual são ofertadas ações de Formação Inicial e Continuada (FIC) do Eixo Turismo, Hospitalidade e Lazer, Eixo Infraestrutura, Eixo saúde e estética, Eixo Desenvolvimento Educacional e Social, Eixo Gestão de Negócios, Eixo Informação e Comunicação, Eixo Produção Alimentícia e Eixo Produção Artística, Cultural e Design, no âmbito das quatro linhas de ação do Programa.
} 
a capacidade de oferta das instituições ofertantes. Assim, a oferta de cursos não atendeu a demanda.

Importa ressaltar que após a reformulação do Programa em 2015, não houve oferta de cursos, devido a uma série de entraves que o MEC enfrentou, assim a demanda inicial levantada pelo MTur não pode ser atendida e as necessidades de qualificação para os Jogos Olímpicos Rio 2016 tiveram que ser suplantadas de forma imediatista por outra ação de qualificação, implementada pelo MTur, o Programa Braços Abertos, que se constituiu em um projeto piloto, desenvolvido em parceria com o Instituto Federal de Educação, Ciência e Tecnologia do Rio de Janeiro (IFRJ) e a Empresa de Turismo do Rio de Janeiro (Riotur), Os cursos foram ofertados a distância somente aos profissionais do Estado do Rio de Janeiro.

Se atendo ao PRONATEC Turismo, percebe-se que a preocupação prioritária do Programa se refere à oferta, tanto pela ampliação dos Institutos Federais, como pelo aumento da oferta dos cursos de qualificação profissional. Expandir as oportunidades educacionais dos trabalhadores também se constitui de uma prioridade, no entanto em termos qualitativos o PRONATEC não conseguiu, até o momento, viabilizar os itinerários formativos, ou seja, implementar ações para que os trabalhadores possam dar continuidade aos seus estudos em um processo de elevação da escolaridade.

No contexto específico do PRONATEC Turismo, instituído pelo MTur em parceria com o MEC e as Secretarias Estaduais e Municipais de Turismo, se constata que o Programa foi concebido em virtude de atender aos megaeventos que o Brasil recebeu entre 2012 e 2016, com foco prioritário para a Copa do Mundo de Futebol FIFA 2014 e os Jogos Olímpicos Rio 2016. Os cursos foram destinados a atender as demandas pontuais relativas às necessidades de qualificação do setor para receber os turistas que visitaram o Brasil nesses eventos, além de ter como objetivo principal aumentar a qualidade e a competitividade dos destinos turísticos.

Neste contexto não foi possível perceber ações de formação/qualificação mais abrangentes com foco nas necessidades dos trabalhadores, bem como que vislumbrassem um processo de educação profissional virtuoso que proporcionasse o desenvolvimento humanizador por meio da elevação da escolaridade, 
empregabilidade, construção de carreiras, reconhecimento, entre outros fatores inerentes a inclusão social.

Outro fator limitante do Programa diz respeito à inserção dos profissionais qualificados no mercado de trabalho do setor, apesar disso constar como um dos seus objetivos, não houve um efetivo movimento para que isso acontecesse.

Pelo exposto nota-se que a educação profissional no País pouco avançou nos últimos 10 (dez) anos a visão predominante ainda é atender as demandas do capitalismo e da economia, na qual coloca a responsabilidade da empregabilidade nas mãos dos trabalhadores, por entender de forma reducionista que as ações de qualificação profissional por si só induzem a empregabilidade e a inclusão social. 


\section{CAPÍTULO 2: A MATERIALIDADE HISTÓRICA DA POLÍTICA DE EDUCAÇÃO PROFISSIONAL EM TURISMO NO BRASIL}

Neste capítulo apresenta-se o método e a metodologia empregada neste estudo, os caminhos trilhados, bem como os instrumentos metodológicos utilizados para analisar o problema de pesquisa se o Programa de Qualificação Profissional PRONATEC Turismo foi possibilitador da inclusão social de seus egressos no setor de Turismo e Hospitalidade.

O Materialismo Histórico Dialético foi adotado como método de abordagem por possibilitar na análise de conteúdo identificar as contradições entre a teoria (discursos oficiais) e a prática (efetivação da política de formação profissional). O método $(\mathrm{MDH})$ dialoga com a realidade da qualificação profissional (PRONATEC Turismo) ao evidenciar as relações estabelecidas pelos sujeitos (setor público, privado, profissionais, egressos e empresários) na produção da materialidade da ação formativa. Tornando possível o entendimento do "status quo" da qualificação e a sua relação com a inclusão social de jovens e adultos no mundo do trabalho formal do setor.

Essa trilha metodológica permitiu a desconstrução do que esta posto sobre o tema. A partir da pesquisa avaliativa que evidencia as contradições dialéticas presentes na relação teoria e prática, como desvelamento das contradições existentes na ação proposta. As categorias a posteriori como instrumentos analíticos foram: inclusão social, desenvolvimento humano e qualificação profissional como possibilidade de construção de carreiras, que possibilitaram a análise objetiva do problema desta pesquisa.

\subsection{Caminhos metodológicos: processo de construção do Objeto de Pesquisa}

O Programa Nacional de Acesso ao Ensino Técnico e Emprego vinculado ao setor de Turismo (PRONATEC Turismo) contribuiu para a inclusão social de jovens e adultos no mercado de trabalho formal do setor de Turismo e Hospitalidade, por meio de ações de educação profissional que propiciasse uma formação emancipatória e cidadã, ou por outro lado, foram restritas em atender aos interesses 
do mercado, no aumento da competitividade e da qualidade dos destinos turísticos? Os cursos ofertados restringiram-se a ações pontuais para uma qualificação mínima aos postos de trabalho oriundos dos megaeventos esportivo, portanto, um atendimento pontual e emergencial do vazio de uma política de formação profissional para o Turismo. Para responder esse problema é necessário atender ao objetivo geral proposto nesta pesquisa, ou seja, o de analisar a extensão das ações executadas pelo PRONATEC Turismo na possibilidade da inclusão social de jovens e adultos no mercado de trabalho formal de Turismo e Hospitalidade.

Deste modo, para se atingir esse objetivo geral foram definidos os seguintes objetivos específicos:

- Identificar a relação do Programa PRONATEC Turismo, no período de 2012-2015, em relação às Atividades Características do Turismo (ACTs) e cursos de profissionalização correlatos.

- Analisar a relação entre a empregabilidade no período dos megaeventos esportivos e a inclusão social de jovens e adultos, egressos do PRONATEC Turismo, nas cidades sedes.

- Identificar a correlação entre as tipologias de cursos ofertados pelo PRONATEC Turismo às necessidades de demanda de trabalhadores das cidades sedes.

- Analisar se a formação profissional do PRONATEC Turismo foi possibilitadora do desenvolvimento humano dos seus egressos e consequente inclusão social.

Esta pesquisa, do ponto de vista de sua natureza, é uma pesquisa aplicada, pois objetiva gerar conhecimentos dirigidos à resolução das seguintes questões de pesquisa:

1. As ações de qualificação profissional empreendidas pelo MTur por meio do PRONATEC Turismo são correlatas às ACT's e consequentemente estruturantes de uma carreira profissional?

2. As ações de qualificação pelo PRONATEC Turismo induziram o aumento de empregabilidade de jovens e adultos nos anos 2014-2016 no setor de turismo e hospitalidade? 
3. Qual o papel da qualificação profissional em turismo para o desenvolvimento humano dos egressos do PRONATEC Turismo?

4. O PRONATEC Turismo possibilitou a construção de carreiras profissionais aos seus egressos no setor de Turismo e Hospitalidade?

Quanto à forma de abordagem do problema, a pesquisa é definida como pesquisa qualitativa, pois considera que existe uma relação entre o sujeito e o universo real, ou seja, um vínculo indissociável entre o mundo objetivo e a subjetividade do sujeito que não pode ser traduzida em números. (Silva; Menezes, 2001).

A partir dos objetivos classifica-se a pesquisa como exploratória e interpretativa, pois se utiliza de análise documental, entrevistas com trabalhadores, egressos, professores e gestores do sistema turístico (ACTs) que participaram do PRONATEC Turismo, executados nas cidades sedes da COPA do Mundo de Futebol FIFA 2014, com base em dados do Núcleo de políticas públicas em turismo (NPPT/CET/UnB) contido na plataforma da Pesquisa Avaliativa dos Arranjos Territoriais Possibilitadores da Qualificação em Turismo (2016), parte do projeto para a Concepção da Política Nacional de Qualificação Profissional em turismo do MTur que ainda encontra-se em andamento.

Essa Pesquisa subsidiou o documento referencial para formulação da Política Nacional de Formação Profissional em Turismo e Hospitalidade, com o intuito de reconstruir a trajetória das práticas de qualificação em Turismo e hospitalidade, com base nas experiências de gestores, professores e egressos em 70 municípios selecionados como amostra representativa, que implementaram projetos de qualificação financiados pelo Ministério do Turismo, no período de 2004 a 2015 e/ou o PRONATEC Turismo.

Como o recorte espacial deste estudo foram as 12 cidades/sede da COPA do Mundo FIFA de Futebol 2014, (Brasília, Cuiabá, Belo Horizonte, Rio de Janeiro, São Paulo, Salvador, Fortaleza, Natal, Recife, Curitiba, Porto Alegre e Manaus), que representam as regiões Centro-oeste, Sudeste, Nordeste, Sul e Norte respectivamente a análise de conteúdo ocorreu a partir das entrevistas realizadas apenas no âmbito do PRONATEC Turismo, com vistas a buscar nos discursos dos sujeitos envolvidos no processo de implantação do Programa respostas as 
categorias operatórias a posteriori selecionadas: inclusão social, desenvolvimento humano e qualificação profissional como possibilidade de construção de carreiras.

A metodologia envolveu ainda um estudo avaliativo a fim de identificar, obter e proporcionar de maneira válida e confiável dados e informações suficientes para apoiar um juízo sobre o mérito e o valor de diferentes componentes do processo social identificando a extensão e o grau em que se deram as ações de qualificação profissional em Turismo e hospitalidade. Assim, configura-se a pesquisa como avaliativa entendendo-a como uma pesquisa social, sistemática, planejada e dirigida. Organizar um fluxo de informações e dados significativos, do ponto de vista qualitativo e quantitativo, e analisar a informação reunida para verificar se as ações de qualificação empreendidas pelo PRONATEC Turismo propiciaram a inclusão social de jovens e adultos no mercado de trabalho formal de Turismo e Hospitalidade.

\begin{abstract}
A pesquisa avaliativa é uma forma de pesquisa social aplicada, sistemática, planejada e dirigida; destinada a identificar, obter e proporcionar de maneira válida e confiável dados e informações suficientes e relevantes para apoiar um juízo sobre o mérito e o valor de diferentes componentes de um programa (tanto na fase do diagnóstico, programação e execução), ou de um conjunto de atividades específicas que se realizam, foram realizadas ou se realizarão com o propósito de produzir efeitos e resultados concretos; comprovando a extensão e o grau em que se deram essas conquistas, de forma tal que sirva de base ou guia para uma tomada de decisão racional e inteligente entre cursos de ação, ou para solucionar problemas e promover o conhecimento e compreensão dos fatores associados ao êxito ou ao fracasso de seus resultados. (AGUILAR; ANDER-EGG, 1994).
\end{abstract}

Com objetivo de evidenciar elementos que respondam ao problema de pesquisa será utilizou-se a metodologia de análise documental a partir de Cellard "a análise documental permite acrescentar a dimensão do tempo à compreensão do social, graças aos documentos pode-se operar um corte longitudinal que favorece a observação do processo de maturação ou de evolução de grupos". (CELLARD, 2008, p. 295). O estudo dos documentos possibilitará contextualizar o texto produzido, o autor e atores sociais em cena, a partir da confiabilidade dos documentos acessados. 
O estudo foi realizado a partir do entendimento de duas articulações institucionais responsáveis pela qualificação dos cidadãos no Brasil, ou seja, o MTur (recorte dessa pesquisa) e o Ministério da Educação.

\subsubsection{Procedimentos da ANÁlise documental}

A análise documental como metodologia, segundo Cellard compõem-se de diferentes momentos de investigação, conforme figura 11 abaixo:

Figura 10 - Ilustração da estrutura da análise documental

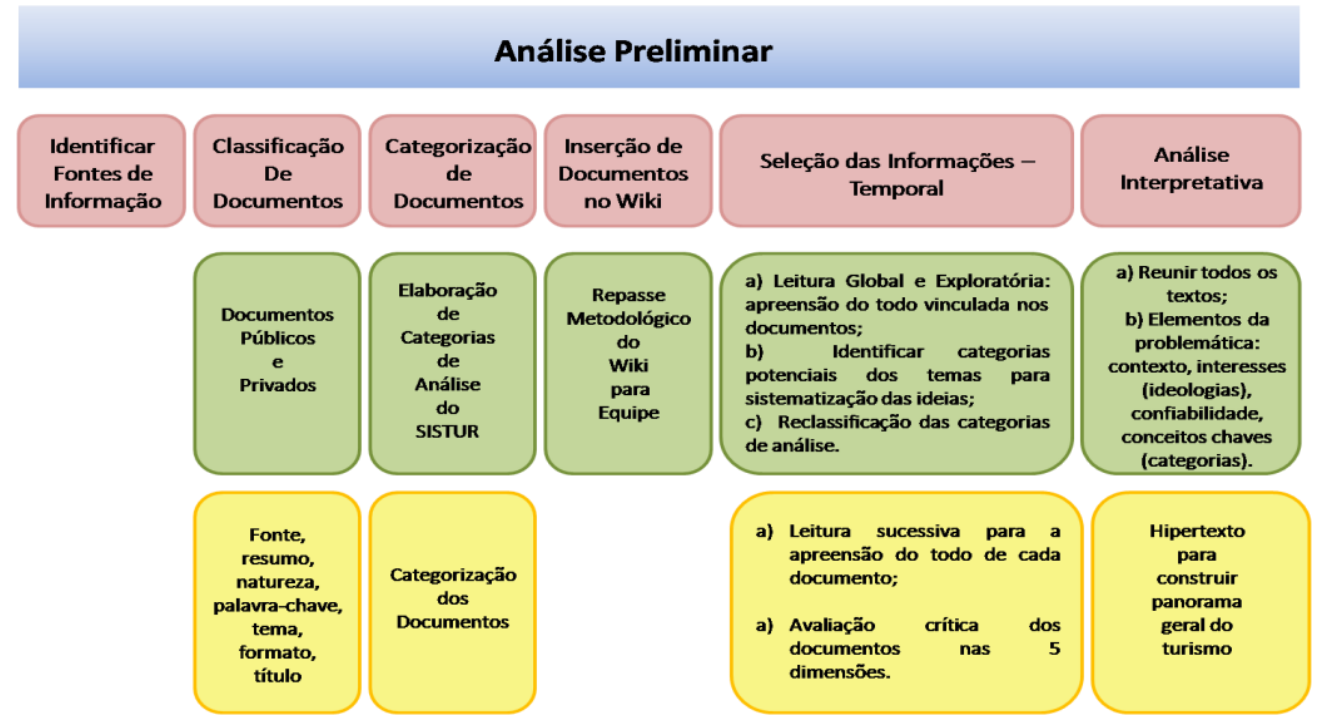

Fonte: Cellard, 2008.

O primeiro passo da análise documental é o estudo exploratório para identificar as fontes de informação, que foi realizado a partir da análise de dados secundários, estudos e coleta de dados realizados pela IPEA; CET/UnB; IBGE, RAIS, Ministério da Educação, Ministério do Trabalho e Emprego, Ministério do Turismo, Secretarias Municipais e Estaduais de Turismo dos estados respectivos das cidades sedes, SISTEC/MEC, SIPROTUR/MTur, Sistema S (SENAC/SENAI/SENAT), Institutos de Educação Profissional. Com a finalidade de obter informações sobre: 
- $\quad$ Características gerais do setor e das ocupações;

- Características de grupo de atividades características do turismo e outras;

- Perfil da mão de obra ocupada nas atividades características do turismo e outras;

- Característica da oferta de qualificação para o setor turístico nas 12 cidades sedes da COPA FIFA de Futebol 2014;

- Levantamento dos cursos ofertados pelo PRONATEC Turismo nas instituições credenciadas junto ao Ministério da Educação que informaram algum Curso na área de Turismo, Lazer e Gastronomia SISTEC/MEC, segundo cidades sedes da Copa e das Olímpiadas;

- Planos Nacionais do Turismo;

- $\quad$ Planos de cursos do PRONATEC Turismo;

- $\quad$ Plano Nacional de Educação.

A figura 12 abaixo apresenta a estrutura da análise documental utilizada nesta pesquisa:

Figura 11 - Estrutura da análise documental

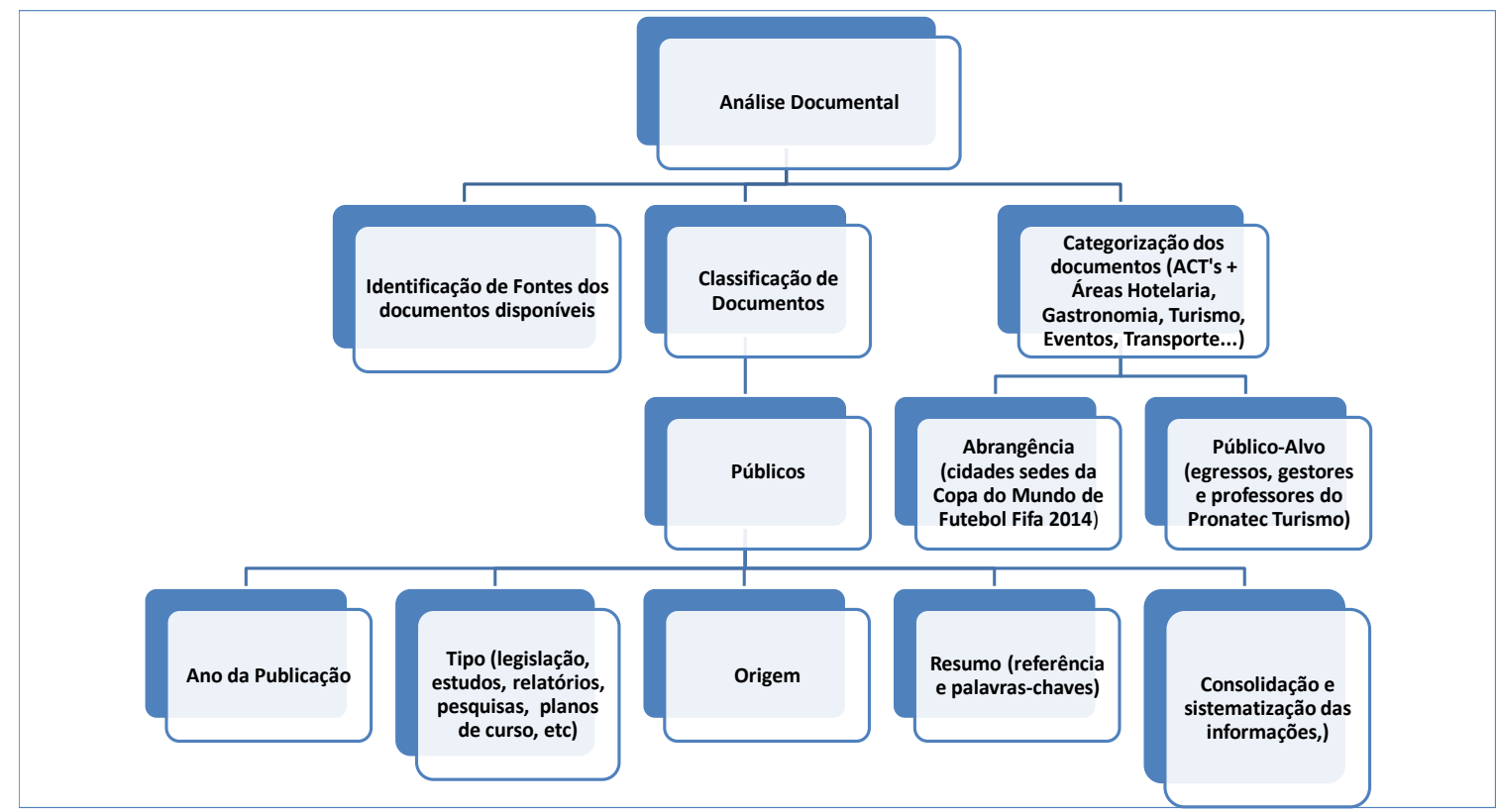

Fonte: elaborada pela autora dapatado de Cellard, 2008 
A primeira etapa da análise documental abrange um estudo qualitativo, contemplando o exame crítico dos documentos referentes às normas que regem o turismo, a educação e o trabalho, das informações que estruturam a oferta da qualificação pelo PRONATEC Turismo, a partir do recorte espacial. Os documentos selecionados nessa etapa da pesquisa foram: planos de cursos do PRONATEC Turismo, Estudos sobre o mercado de trabalho do turismo e das Atividades Características do Turismo (ACT's), relatórios do MTur/MEC sobre a execução dos cursos, levantamentos de demandas por qualificação feito pelas cidades sedes, Pesquisa avaliativa dos arranjos territoriais possibilitadores da qualificação em turismo, banco de dados da pesquisa avaliativa (processos que compõem a estruturação da Política Nacional de Qualificação em Turismo), pesquisa com egressos, do PRONATEC Turismo (MTur), entre outros documentos.

O Objetivo da análise documental foi a representação condensada da informação, para consulta e armazenamento; dar forma e representar de outro modo as informações obtidas, por intermédio de procedimentos de transformação. (BARDIN, 2011). As informações obtidas na análise documental estão sistematizadas conforme modelo apresentados nos quadros 5 e 6 abaixo, contemplando: as normas internacionais e nacionais para o turismo, como: International Standard Industrial Classification (ISIC - OMT), Lei Geral do Turismo (no 11.771/2008), Inventário da Oferta Turística (INVTUR), Atividades Características do Turismo (ACT's - IPEA) Classificação Nacional de Atividades Econômicas (CNAE - IBGE), Classificação Brasileira de Ocupações (CBO - MTE), Associação Brasileira de Normas Técnicas (ABNT).

O objetivo dessa sistematização foi verificar se os cursos ofertados pelo PRONATEC Turismo foram concebidos em observância as normas que devem preceder as políticas de turismo e hospitalidade e as normas do trabalho e emprego adotadas no Brasil, a fim de estruturar cursos de qualificação que pudessem proporcionar a inclusão dos sujeitos no mundo do trabalho e a construção de carreiras do setor ou se restringiram apenas a ofertar cursos pontuais para atender as demandas dos megaeventos. 
Quadro 5 - Subsídios para análise documental (a)

\begin{tabular}{|c|c|c|c|c|c|c|}
\hline \multicolumn{7}{|c|}{ NORMATIZAÇÃO EM TURISMO E HOSPITALIDADE E NO TRABALHO } \\
\hline $\begin{array}{c}\text { Diretrizes } \\
\text { Internacionais }\end{array}$ & $\begin{array}{r}\text { Diretrizes Nacic } \\
\mathrm{Tu}\end{array}$ & $\begin{array}{l}\text { is Ministério do } \\
\text { mo }\end{array}$ & $\begin{array}{r}\text { Atividades Car } \\
\text { Turi }\end{array}$ & $\begin{array}{l}\text { acterísticas do } \\
\text { mo }\end{array}$ & & Ocupações \\
\hline $\begin{array}{l}\text { International Standard } \\
\text { Industrial } \\
\text { Classification } \\
\text { ISIC - OMT }\end{array}$ & $\begin{array}{l}\text { Lei Geral do } \\
\text { Turismo } \\
\text { № 11.771/2008 }\end{array}$ & $\begin{array}{l}\text { Inventário da } \\
\text { Oferta Turística } \\
\text { INVTUR }\end{array}$ & $\begin{array}{l}\text { Atividades } \\
\text { Características } \\
\text { do Turismo } \\
\text { ACT's - IPEA }\end{array}$ & $\begin{array}{l}\text { Classificação } \\
\text { Nacional de } \\
\text { Atividades } \\
\text { Econômicas } \\
\text { CNAE - IBGE }\end{array}$ & $\begin{array}{l}\text { Classificação } \\
\text { Brasileira de } \\
\text { Ocupações } \\
\text { CBO - MTE }\end{array}$ & $\begin{array}{c}\text { Associação Brasileira de Normas } \\
\text { Técnicas } \\
\text { ABNT }\end{array}$ \\
\hline Serviço de alojamento & $\begin{array}{c}\text { Meios de } \\
\text { hospedagem }\end{array}$ & $\begin{array}{c}\text { Serviços e } \\
\text { equipamentos de } \\
\text { meios de } \\
\text { hospedagem }\end{array}$ & Alojamento & $\begin{array}{l}55.108 \text { Hotéis e } \\
\text { similares }\end{array}$ & $\begin{array}{l}\text { 1415-25 Gerente de } \\
\text { Turismo } \\
\text { 1415-05 - Gerente } \\
\text { de hotel }\end{array}$ & $\begin{array}{l}\text { ABNT NBR 15035:2004 - } \\
\text { Recepcionista em função polivalente } \\
\text { - Competência de pessoal } \\
\text { ABNT NBR 15030:2004 - } \\
\text { Hospitalidade para profissionais } \\
\text { operacionais }\end{array}$ \\
\hline
\end{tabular}

Fonte: Elaborado pela autora, 2016 
Quadro 6 - Subsídios para análise documental (b)

\begin{tabular}{|c|c|c|c|}
\hline \multicolumn{4}{|c|}{ Cursos de Qualificação } \\
\hline $\begin{array}{l}\text { Cursos de } \\
\text { Qualificação } \\
\text { PRONATEC }\end{array}$ & \multicolumn{3}{|c|}{ Grade curricular - Guia FIC } \\
\hline $\begin{array}{l}\text { Recepcionista em } \\
\text { meios de hospedagem }\end{array}$ & $\begin{array}{l}\text { INSTITUTO FEDERAL } \\
\text { ENSINO MEDIO INCOMPLETO } \\
\text { 1. Fundamentos da Hospitalidade e } \\
\text { do Turismo } \\
\text { 2. Operação de Recepção } \\
\text { 3. Relaçôes Interpessoais e Imagem } \\
\text { Pessoal } \\
\text { 4. Linguagem e Comunicação } \\
\text { 5.Técnicas de Dicção e Oratória } \\
\text { Aplicadas ao recepcionista em meios } \\
\text { de hospedagem } \\
\text { TOTAL } 160 \mathrm{~h}\end{array}$ & $\begin{array}{l}\text { INSTITUTO FEDERAL } \\
\text { ENSINO MEDIO INCOMPLETO } \\
\text { 1. Fundamentos da Hospitalidade e do Turismo } \\
\text { 2. Operação de Recepção } \\
\text { 3. Relações Interpessoais e Imagem Pessoal } \\
\text { 4. Linguagem e Comunicação } \\
\text { 5.Técnicas de Dicção e Oratória Aplicadas ao } \\
\text { recepcionista em meios de hospedagem } \\
\text { TOTAL } 160 \mathrm{~h}\end{array}$ & $\begin{array}{l}\text { INSTITUTO]FEDERAL } \\
\text { ENSINO MEDIO INCOMPLETO } \\
\text { 1. Introdução ao Turismo e Hotelaria } \\
\text { 2.Ética e Relações interpessoais nos } \\
\text { meios de hospedagem } \\
\text { 3.Inglês Instrumental } \\
\text { 4.Organização Hoteleira I } \\
\text { 5.Integração e Orientação Profissional } \\
\text { 6.Técnicas de atendimento ao cliente e } \\
\text { assistência ao turista } \\
\text { 7.Organização Hoteleira II } \\
\text { 8.Segurança no Trabalho } \\
\text { 9.Legislação Turística } \\
\text { TOTAL 200h }\end{array}$ \\
\hline $\begin{array}{l}\text { Camareira em meios } \\
\text { de hospedagem }\end{array}$ & $\begin{array}{l}\text { ENSINO FUNDAMENTAL COMPLETO } \\
\text { 1.Fundamentos de Turismo e } \\
\text { Hospitalidade } \\
\text { 2.Atendimento ao Cliente } \\
\text { 3.Ética, Cidadania e Relações } \\
\text { 5.Interpessoais } \\
\text { 4.Técnicas de limpeza, higienização e } \\
\text { arrumação de unidades habitacionais } \\
\text { 5.Saúde e Segurança do Trabalho } \\
\text { 6.Informatica Básica } \\
\text { 7.Leitura e Produção de Texto } \\
\text { 8.Serviços de Setor de Governança }\end{array}$ & $\begin{array}{l}\text { ENSINO FUNDAMENTAL COMPLETO } \\
\text { 1.Leitura e Produção de Textos } \\
\text { 2.Matemática Básica } \\
\text { 3.Língua Estrangeira (Inglês Aplicado à } \\
\text { Hotelaria) } \\
\text { 4.Informática Básica } \\
\text { 5.Relações Interpessoais } \\
\text { 6. Cidadania } \\
\text { 7.Ética Profissional } \\
\text { 8.Qualidade de Vida no trabalho } \\
\text { 9.Introdução ao Turismo e à Hospitalidade } \\
\text { 10.Rotinas e Técnicas do Trabalho de } \\
\text { Camareira em Meios de Hospedagem } \\
\text { 11.Seminários de Prática Profissional }\end{array}$ & $\begin{array}{l}\text { SENAC } \\
\text { Revisão de técnicas } \\
\text { I - Atribuições da Camareira } \\
\text { II - Material de Trabalho } \\
\text { III - Higienização e Arrumação } \\
\text { TOTAL: } 20 \text { horas }\end{array}$ \\
\hline
\end{tabular}

Fonte: Elaborado pela autora, 2016 LEGENDA: conteúdos cidadania - Conteúdos Transversais 
Os dados dessa análise foram essenciais ao permitir verificar se os cursos executados nas 12 cidades sedes da COPA do Mundo FIFA de Futebol 2014 fazem correlação com as diretrizes internacionais e nacionais do Turismo, as ACT's, o Código Brasileiro de Ocupações (CBO), as Normas Técnicas da ABNT para o setor de turismo e hospitalidade, além de averiguar se os conteúdos presentes nos planos de cursos trabalham a transversalidade do Turismo visando uma formação integral dos trabalhadores do setor.

O quadro teórico da pesquisa perpassa pelos campos de inclusão social possibilitadora de desenvolvimento humano pelo turismo, conforme se demonstra no esquema 1. Os achados da análise de conteúdo a partir das categorias a priori do MHD serão analisadas a luz das teorias de desenvolvimento humano, qualificação possibilitadora de uma carreira e inclusão social, numa relação dialética conforme ilustração abaixo:

Esquema 1 - Quadro teórico

Desenvolvimento Humano pelo Turismo

Qualificação Profissional como possibilidade de construção de carreira

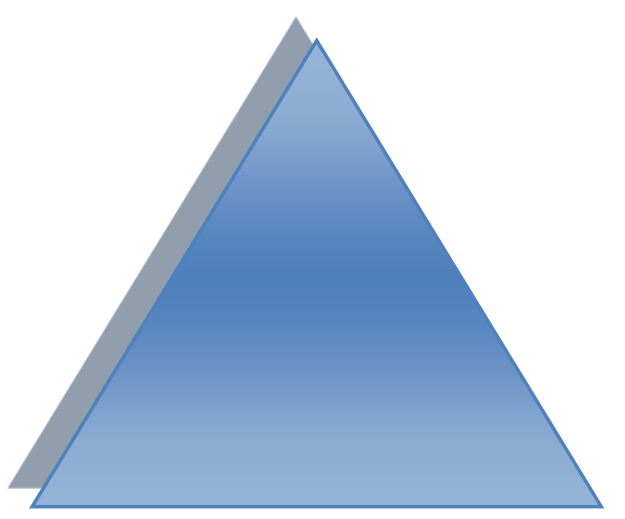

Inclusão social

Fonte: Elaborada pela autora, 2016

A análise de conteúdo foi realizada por meio de um conjunto de instrumentos metodológicos, aplicados a discursos diversificados, baseados na dedução e na inferência. (BARDIN, 2011). Utilizaram-se como insumos os documentos que compõem a Pesquisa Avaliativa dos Arranjos territoriais possibilitadores da qualificação em turismo para aplicar essa técnica de pesquisa. 
Essa técnica utiliza o procedimento normal da investigação (o confronto entre o quadro de referência do investigador e o material empírico recolhido). Neste sentido, a análise de conteúdo tem uma dimensão descritiva que visa dar conta de interpretar os materiais recolhidos. (GUERRA, 2006).

$O$ tratamento das informações do banco de dados da Pesquisa avaliativa dos arranjos territoriais possibilitadores da qualificação em turismo (CET/UnB) e da pesquisa com egressos do PRONATEC Turismo (MTur) será realizado a partir da análise de conteúdo. A Análise de Conteúdo (AC) é um conjunto de técnicas de análise das comunicações visando obter, por procedimentos, sistemáticos e objetivos de descrição do conteúdo das mensagens, indicadores (quantitativos ou não) que permitam a inferência de conhecimentos relativos às condições de produção/recepção destas mensagens. (BARDIN, 2011).

A Análise de Conteúdo pode ser quantitativa e qualitativa:

- $\mathrm{Na}$ abordagem quantitativa se traça uma frequência das características que se repetem no conteúdo do texto;

- Na abordagem qualitativa se considera a presença ou a ausência de uma dada característica de conteúdo ou conjunto de características num determinado fragmento da mensagem. (BARDIN, 2011).

$\mathrm{Na}$ Análise de conteúdo o texto é um meio de expressão do sujeito, a partir do qual o analista busca categorizar as unidades de texto (palavras ou frases) que se repetem, inferindo uma expressão que as representem. A análise por categorias temáticas busca encontrar uma série de significações que o pesquisador detecta por meio de indicadores conexos; de modo caracterizar uma amostra e alocá-la em uma das classes correspondentes, a partir das definições. Procedimento que exige treinamento e qualidades psicológicas complementares como a cortesia, a sensibilidade a flexibilidade, por parte do pesquisador para perceber o que e fato importa. (BARDIN, 2011).

A análise categorial é o tipo de análise mais antiga e a mais utilizada, e funciona por operações de desmembramento do texto em unidades, em categorias segundo reagrupamentos analógicos. (BARDIN, 2011). Ou seja, para classificar os elementos em categorias é preciso identificar o que eles têm em comum, permitindo seu agrupamento. 
A análise categorial também pode ser temática, construindo as categorias conforme os temas que emergem do texto.

Em suma, a técnica de Análise de Conteúdo, se compõe de três grandes etapas:

1) pré-análise: fase de organização, que pode utilizar vários procedimentos tais como leitura, hipóteses, objetivos e elaboração de indicadores que fundamentem a interpretação.

2) a exploração do material: os dados são codificados a partir das unidades de registro;

3) $\quad$ o tratamento dos resultados e interpretação: realiza-se a categorização, que consiste na classificação dos elementos segundo suas semelhanças e por diferenciação, com posterior reagrupamento, em função de características comuns.

Existem dois tipos de textos que podem ser trabalhados pela Análise de Conteúdo: (1) os textos produzidos em pesquisa, através das transcrições de entrevista e dos protocolos de observação; e (2) os textos já existentes, produzidos para outros fins, como textos de jornais. Nesta pesquisa se utilizará dos dois tipos de textos.

Pela análise de conteúdo espera-se compreender o pensamento do sujeito através do conteúdo expresso no texto, numa concepção transparente de linguagem, pois o que se busca são as significações que o pesquisador percebe por meio dos indicadores determinados. (BARDIN, 2011).

O quadros 7 abaixo, estabelece a análise de conteúdo dos achados e a relação dialética entre a teoria e a prática. 
Quadro 7 - Sistematização da análise de conteúdo (modelo)

\begin{tabular}{|c|c|c|c|c|c|c|c|c|}
\hline \multicolumn{3}{|c|}{ CATEGORIAS A PRIORI } & \multicolumn{6}{|c|}{ CATEGORIAS MATERIALISMO HISTORICO-DIALETICO } \\
\hline Categorias & Concepções & Avanços & $\begin{array}{l}\text { Teoria } \\
\text { prática }\end{array}$ & $\begin{array}{l}\text { Totalidade } \\
\text { fragmentação }\end{array}$ & $\begin{array}{l}\text { Contradição } \\
\text { mediação }\end{array}$ & $\begin{array}{l}\text { Subjetividade } \\
\text { objetividade }\end{array}$ & \begin{tabular}{|l|} 
Autonomia \\
dependência \\
\end{tabular} & $\begin{array}{l}\text { Criticidade } \\
\text { alienação }\end{array}$ \\
\hline $\begin{array}{l}\text { Inclusão social: } \\
\text { A inclusão dos } \\
\text { sujeitos é } \\
\text { determinante para } \\
\text { uma vida ativa e o } \\
\text { equilíbrio das } \\
\text { oportunidades em } \\
\text { sociedade, } \\
\text { considerando que } \\
\text { essa inclusão } \\
\text { prioritariamente } \\
\text { começa pelo acesso } \\
\text { ao emprego } \\
\text { qualificante, } \\
\text { possibilitador do } \\
\text { crescimento } \\
\text { profissional, espaço } \\
\text { onde o trabalhador } \\
\text { possa criar, } \\
\text { desenvolver-se e ter } \\
\text { suas } \\
\text { individualidades } \\
\text { respeitadas. Acesso } \\
\text { aos direitos sociais, } \\
\text { políticos, civis, } \\
\text { econômicos, } \\
\text { culturais e ao lazer. }\end{array}$ & $\begin{array}{l}\text { "O que poderia ter } \\
\text { sido... era realizar } \\
\text { uma avaliação } \\
\text { com os } \\
\text { concluintes após o } \\
\text { término do curso. } \\
\text { E verificar se } \\
\text { conseguiram um } \\
\text { emprego..." }\end{array}$ & $\begin{array}{l}\text { "falhamos em não } \\
\text { ter um } \\
\text { monitoramento, } \\
\text { encaminhamento } \\
\text { para um } \\
\text { emprego". }\end{array}$ & $\begin{array}{l}\text { Porque as } \\
\text { desistências } \\
\text { ocorreram... } \\
\text { "arranjar } \\
\text { emprego, } \\
\text { desinteresse } \\
\text { pelo tema e } \\
\text { desinteresse do } \\
\text { aluno". } \\
\text { "o mau } \\
\text { direcionamento } \\
\text { dos alunos"... } \\
\text { "...lamentei o } \\
\text { insucesso do } \\
\text { Programa. O } \\
\text { Mercado está } \\
\text { carente de } \\
\text { profissionais } \\
\text { qualificados ." }\end{array}$ & $\begin{array}{l}\text { "Acredito que um } \\
\text { curso de } \\
\text { qualificação em } \\
\text { turismo deve } \\
\text { abranger, de forma } \\
\text { global e } \\
\text { interdisciplinar, } \\
\text { aspectos } \\
\text { econômicos, } \\
\text { políticos e sociais da } \\
\text { atividade turística na } \\
\text { localidade, trazendo } \\
\text { exemplos práticos e } \\
\text { reais". } \\
\text { "... não vejo que } \\
\text { tenha relação direta } \\
\text { com o retorno a } \\
\text { educação formal, } \\
\text { porque tem público } \\
\text { diferente e um foco } \\
\text { diferente. Eu me } \\
\text { preocupo com a } \\
\text { supervalorização } \\
\text { que } \\
\text { atribuem ao } \\
\text { pronatec. Um curso } \\
\text { de } 1 \text { ano e meio não } \\
\text { vai ser igual a um } \\
\text { curso de } 3 \text { meses". }\end{array}$ & $\begin{array}{l}\text { "Se hoje eu } \\
\text { estivesse } \\
\text { atuando como } \\
\text { Guia, acredito } \\
\text { que estaria } \\
\text { muito bem } \\
\text { preparada. As } \\
\text { saídas técnicas } \\
\text { foram muito } \\
\text { importante para } \\
\text { conhecermos } \\
\text { destinos: o que } \\
\text { fazer, por onde } \\
\text { andar" } \\
\\
\text { "Acredito que os } \\
\text { alunos } \\
\text { chegaram ao } \\
\text { curso pela } \\
\text { necessidade de } \\
\text { receber o } \\
\text { seguro } \\
\text { desemprego". }\end{array}$ & $\begin{array}{l}\text { "Não estou } \\
\text { empregado" } \\
\text { "Turismo não é } \\
\text { muito a minha } \\
\text { abordagem". } \\
\text { Futuramente quem } \\
\text { sabe consigo aliar } \\
\text { o turismo, } \\
\text { comércio exterior e } \\
\text { eventos. Tenho } \\
\text { projetos para isso" }\end{array}$ & $\begin{array}{l}\text { "A instabilidade do } \\
\text { mercado impede o } \\
\text { crescimento } \\
\text { pessoal e } \\
\text { profissional" } \\
\text { "Então o curso é } \\
\text { uma } \\
\text { oportunidade para } \\
\text { o aluno e traz uma } \\
\text { perspectiva de } \\
\text { crescimento } \\
\text { pessoal, e tem um } \\
\text { grande valor". }\end{array}$ & $\begin{array}{l}\text { "Em função de } \\
\text { muitos alunos } \\
\text { terem sido } \\
\text { direcionados de } \\
\text { forma errada } \\
\text { (ou faziam o } \\
\text { curso, ou não } \\
\text { receberiam o } \\
\text { seguro } \\
\text { desemprego), } \\
\text { muitos que não } \\
\text { tem vocação para } \\
\text { a área se } \\
\text { desmotivaram". } \\
\text { "Esse período de } \\
3 \text { meses não vai } \\
\text { transformar uma } \\
\text { pessoa leiga em } \\
\text { um } \\
\text { organizador de } \\
\text { eventos... Os } \\
\text { cursos podem ser } \\
\text { mais produtivos } \\
\text { para cursos mais } \\
\text { básicos, } \\
\text { como } \\
\text { recepcionista } \\
\text { e auxiliar de } \\
\text { cozinha" }\end{array}$ \\
\hline
\end{tabular}




\begin{tabular}{|c|c|c|c|c|c|c|c|c|}
\hline \multicolumn{3}{|c|}{ CATEGORIAS A PRIORI } & \multicolumn{6}{|c|}{ CATEGORIAS MATERIALISMO HISTORICO-DIALETICO } \\
\hline Categorias & Concepções & Avanços & $\begin{array}{l}\text { Teoria } \\
\text { prática }\end{array}$ & $\begin{array}{l}\text { Totalidade } \\
\text { fragmentação }\end{array}$ & $\begin{array}{l}\text { Contradição } \\
\text { mediação }\end{array}$ & $\begin{array}{l}\text { Subjetividade } \\
\text { objetividade }\end{array}$ & $\begin{array}{l}\text { Autonomia } \\
\text { dependência }\end{array}$ & $\begin{array}{l}\text { Criticidade } \\
\text { alienação }\end{array}$ \\
\hline $\begin{array}{l}\text { Desenvolvimento } \\
\text { humano/ } \\
\text { Cidadania } \\
\text { E intrínseco ao } \\
\text { desenvolvimento } \\
\text { humano a cidadania } \\
\text { que pressupõe } \\
\text { equidade de } \\
\text { oportunidades. } \\
\text { Tais como ingresso } \\
\text { ao trabalho digno, } \\
\text { acesso à } \\
\text { aposentadoria, à } \\
\text { segurança, à } \\
\text { habitação, à } \\
\text { educação, ao } \\
\text { direito, à cultura e } \\
\text { ao lazer, fatores } \\
\text { essenciais para a } \\
\text { consolidação da } \\
\text { cidadania. E } \\
\text { requisitos para o } \\
\text { desenvolvimento } \\
\text { humano, assim } \\
\text { como a educação } \\
\text { integral dos sujeitos, } \\
\text { que tenha como } \\
\text { objetivo a cidadania, } \\
\text { a liberdade, a } \\
\text { autonomia e a } \\
\text { emancipação. }\end{array}$ & $\begin{array}{l}\text { "Vivo minha } \\
\text { cidadania } \\
\text { respeitando leis e } \\
\text { regras de convívio } \\
\text { social, mas nunca } \\
\text { me engajei em } \\
\text { associações de } \\
\text { moradores do } \\
\text { bairro, ou debati } \\
\text { sobre problemas } \\
\text { sociais locais". } \\
\\
\text { "Os cursos são de } \\
\text { curto período, } \\
\text { então a questão } \\
\text { de cidadania entra } \\
\text { no ditado que o } \\
\text { trabalho dignifica o } \\
\text { homem". }\end{array}$ & $\begin{array}{l}\text { "A escolaridade } \\
\text { dos alunos é } \\
\text { diferente, é } \\
\text { necessário que } \\
\text { tenha um } \\
\text { professor de } \\
\text { empreendedorism } \\
\text { o um psicólogo, } \\
\text { mas isso foi um } \\
\text { aprendizado junto } \\
\text { ao programa". }\end{array}$ & $\begin{array}{l}\text { "Acredito que a } \\
\text { valorização do } \\
\text { profissional em } \\
\text { relação ao } \\
\text { turismo e ao } \\
\text { descobrimento } \\
\text { da importância } \\
\text { do turismo tanto } \\
\text { econômica } \\
\text { quanto social. } \\
\text { Mas isso, nós } \\
\text { temos que ver } \\
\text { que nem todos } \\
\text { os alunos que } \\
\text { vem fazer o } \\
\text { curso são } \\
\text { ligados a área. } \\
\text { E tem uma visão } \\
\text { apenas de } \\
\text { passeio, e que } \\
\text { não é isso o } \\
\text { turismo". } \\
\text { "Não foi } \\
\text { realizada } \\
\text { nenhuma } \\
\text { avaliação". }\end{array}$ & $\begin{array}{l}\text { "Parcialmente, como } \\
\text { a área é muito } \\
\text { ampla, ficaram } \\
\text { muitos vazios de } \\
\text { conteúdos a serem } \\
\text { ministrados". }\end{array}$ & & $\begin{array}{l}\text { "Os professores } \\
\text { indicaram o } \\
\text { conteúdo } \\
\text { necessário". }\end{array}$ & $\begin{array}{l}\text { "Estou cursando } \\
\text { Turismo na UFPR" }\end{array}$ & $\begin{array}{l}\text { Os cursos "não } \\
\text { abrangem a todas } \\
\text { as necessidades } \\
\text { relacionadas ao } \\
\text { tema, ou ao cargo". }\end{array}$ \\
\hline
\end{tabular}

Fonte: Elaborada pela autora (2016) adaptado de Bardin, 2011 
Os dados dessa análise foram fundamentais, pois permitiram caracterizar dentro das 12 cidades sedes da COPA do Mundo FIFA de Futebol 2014 a opinião dos egressos do PRONATEC Turismo, possibilitando avaliar se as ações de qualificação empreendidas representaram um diferencial na vida desses sujeitos e, consequentemente contribuíram para a sua inclusão social por meio do emprego no setor de turismo e hospitalidade.

Por meio do método materialismo histórico dialético, da metodologia de pesquisa qualitativa e das técnicas de pesquisa de análise documental e análise de conteúdo utilizadas neste trabalho para analisar o problema de pesquisa: $O$ Programa de Qualificação Profissional PRONATEC Turismo foi possibilitador da inclusão social de seus egressos no setor de Turismo e Hospitalidade. Espera-se que os insumos e evidências recolhidas permitam desvelar o objeto deste estudo e possibilitar a construção de um conhecimento sobre a realidade da política pública de educação profissional em Turismo.

\subsection{CONCEPÇÃO TEÓRICO METODOLÓGICA: O MATERIALISMO HISTÓRICO DIALÉTICO}

A pesquisa estruturou-se pelo método materialismo histórico dialético que permite reconhecer, no mesmo patamar de relevância, condições objetivas e subjetivas das estruturas histórica (demo, 2000) onde ocorrem as transformações sociais, as histórias (ocorrências) e as estruturas (poder, desigualdade) estão interligadas e denotam a realidade encontrada. Neste contexto o método escolhido possibilitará reconhecer e interpretar as ações de qualificação profissional (PRONATEC turismo) por meio dos sujeitos participantes da construção dessa história.

O método permitiu o entendimento do status quo da política pública de qualificação profissional em turismo, auxiliando identificar se as ações de qualificação implementadas se constituíram em uma educação integral dos sujeitos, ancorada na perspectivas de cidadania e inclusão social.

Busca-se romper com a visão de que as ações de educação/qualificação profissional para serem efetivas necessitam se restringirem ao interesse do 
mercado, ao lançar um novo olhar sobre o tema, por meio da dialética se propõe uma reflexão sobre o que está posto para buscar um novo caminho.

Como o materialismo histórico dialético é um método de interpretação da realidade, cuja base se estabelece na práxis, relação teoria e prática, preocupação política, reconstrução histórica, real contraditório com mediações/contradições a serem superadas, permite buscar as respostas às questões levantadas.

A dialética histórico-estrutural aposta mais nas transformações históricas do que nas estruturais (mudanças profundas), mas, mesmo assim impossível de ser concebidas sem os sujeitos. Tenta apanhar a dimensão intrinsicamente dinâmica da realidade objetiva e subjetiva (DEMO, 2000), ou seja, busca apresentar o objeto da pesquisa mais próximo da realidade encontrada, bem como a interpretação dessa realidade de acordo com as percepções do pesquisador.

A dialética permite pensar as contradições da realidade, o modo de compreender a realidade como essencialmente contraditória e em permanente transformação (KONDER, 2008).

\footnotetext{
Se a dialética se baseia na historicidade e se só o ser humano é propriamente histórico, de tal forma que somente existe como concretohistórico, isto é, sempre determinado por uma situação histórica concreta, então a dialética só pode encontrar seu pleno sentido na história concreta do ser humano. Não cabe tal pressuposto na natureza, pelo que não faz sentido perguntar-se pela antítese de uma pedra. Uma pedra não é um ser histórico, marcado pelo conflito social. (DEMO, 1995, p.91).
}

A interpretação é dinâmica e totalizante da realidade, sendo que os fatos sociais não podem ser entendidos quando considerados isoladamente, abstraídos do contexto social, político, econômico e cultural - onde o todo é maior que a soma das partes, pois o método dialético se realiza plena e rigorosamente na captação do movimento histórico em suas contradições constituintes. (BRUYNE,1977).

Pode-se dizer que o principal enfoque da dialética é o conceito de antítese, no qual toda realidade social, pela sua dinâmica interna própria, gera seu contrário, ou as condições objetivas e subjetivas para sua superação. A antítese alimenta-se da estrutura do conflito social, tornando-se marca estrutural da história. O esquema básico do método consagra a trilogia: tese, antítese, síntese. (DEMO, 1990).

A tese inicial desta pesquisa consiste da percepção, na prática, de que a política pública de educação profissional em turismo, implementada pelo 
PRONATEC Turismo, não possibilitou a inclusão social dos egressos das ações de qualificação executadas, pelo entendimento de que essas ações não foram concebidas para atender as demandas e necessidades dos trabalhadores do setor. A visão predominante para a educação profissional continua atrelada ao desenvolvimento/crescimento econômico e não a transformação efetiva dos sujeitos pela educação.

A antítese se constitui de uma inferência de que a política pública de educação profissional em turismo, implementada pelo PRONATEC Turismo, pode ser possibilitadora da inclusão social dos egressos dos cursos de qualificação profissional.

A síntese buscara a mediação entre as contradições encontradas no processo histórico estabelecido pelo Programa de Qualificação Profissional PRONATEC Turismo e seus limites e possibilidades como instrumento de uma política pública para a inclusão social de seus egressos, já que o mesmo programa tem continuidade como modalidade de formação profissional no país.

\subsubsection{Categorias Operatórias}

\subsubsection{Categorias operatórias de análise a priori}

Para fundamentar a análise documental e possibilitar a análise de conteúdo recorreu-se as teorias que abordam categorias operatórias como matéria, práxis, historicidade, teoria/prática, totalidade/fragmentação, contradição/mediação, objetividade/subjetividade, autonomia/dependência, criticidade/alienação. Essas categorias foram utilizadas para interpretar os dados:

Matéria: é objetiva, existe independentemente da consciência. A matéria engloba todas as formas de realidade objetiva, sendo duas formas gerais de existência da matéria: o Espaço e o Tempo, prescindindo a existência de territórios, ecossistemas (Espaço e movimento) a dinâmica que Ihe é imanente (Tempo). O fenômeno turístico compõe-se pela matéria, pois necessita expressar-se no Tempo e no Espaço, tendo como sua forma fundamental um sistema social tecido nesse território. (MOESCH, 2002). 
Práxis: um processo, movimento que se dinamiza por contradições, cuja superação o conduz a patamares de crescente complexidade, nos quais novas contradições impulsionam a outras superações na relação teoria-prática. (PAULO NETTO, 2011).

Historicidade: a dialética traz uma ligação com processos históricos de mudança, considerando que toda formação histórica está sempre em transição, o que supõe a visão intrinsecamente dinâmica da realidade social, no sentido da produtividade histórica e transformação permanente. (DEMO, 1995).

Teoria/prática: teoria necessita de prática e vice-versa, embora cada uma tenha a sua lógica; para renovar-se, toda prática necessita voltar para teoria, desse modo, elas se complementam.

Totalidade/fragmentação: a totalidade não possui apenas a dinâmica circular, que é sempre a mesma e lhe permitiria recuperar-se eternamente, a dinâmica consiste em dinâmicas contrárias, feitas de convergências e divergências, sobrepondo-se, assim, as convergências, a totalidade continua e do contrário, temse outra totalidade. (DEMO, 2000).

Contradição/mediação: toda formação social é contraditória conforme Demo (1990), sendo a formação social uma realidade que se forma processualmente, na história, cujo aspecto formativo histórico é sempre dinâmico, na unidade dos contrários. (MOESCH, 1999).

Objetividade/Subjetividade: para além das condições objetivas, a realidade social é movida igualmente por condições subjetivas, pois a história se "move" por leis necessárias objetivas, mas a par de seu lado objetivo natural, possui o lado subjetivo, político, de conquista humana cultural. Considera-se, assim, as condições objetivas aquelas dadas externamente ao homem, ou dadas sem sua opção própria e considera-se as condições subjetivas aquelas dependentes da opção humana, a capacidade de construir a história em parte, no contexto das condições objetivas. (DEMO, 1995).

Autonomia/dependência: a manifestação do sujeito em sociedade, ocorre pela interação deste com o contexto de sua realidade, essa relação não ocorre de forma individual e específica, está sempre relacionada com os objetos, pela interação parcial e concreta, aceita pela sociedade ou grupos sociais no qual estão inseridos. 
A noção da autonomia humana é um processo complexo, como todos os demais que envolvem o sujeito, ela depende de condições culturais e sociais para existir. Essa autonomia se alimenta da dependência e vice versa. Depende-se de uma educação, de uma linguagem, de uma cultura, de uma sociedade, para a construção do refletir de maneira autônoma. (MORIN, 2005).

Criticidade/alienação: o "alienar-se" passivamente na corrente dominante contribui para manter a situação estabelecida, reprodução do passado. (MOESCH, 1999). O contra fluxo desse movimento se estabelece na crítica, considerando que a coerência da crítica está na autocrítica, pois não é possível, por lógica e por justiça, criticar sem apresentar-se como criticável. Logo, a crítica se completa na contraproposta, de cunho prático, não sendo sustentável a mera crítica, destrutiva, sem compromisso com alguma construção concreta. (DEMO, 1995).

\subsubsection{Categorias operatórias de análise a posteriori}

Para tonar a análise mais objetiva identificam-se as categorias a posteriori para apoiar a interpretação das evidências que foram discutidas na pesquisa como: inclusão social, cidadania, desenvolvimento humano, Educação profissional possibiliatdora da construção de carreira profissional no setor turismo e hospitalidade.

A categoria de Inclusão social: Sheppard (2006), Kunzer, Sachs (2008), Irving at. al. (2015), Bergonsi \& Lacerda (2007), Gentili \& Frigotto (2000). Desenvolvimento humano, que perpassa pela cidadania, foi constituída a partir dos seguintes autores: PNUD (2015), Sachs, (2008), Ivo (2013), Adorno (1995), Gastal \& Moesch (2007), Demo (1992, 1994, 995 e 2006), Santos (2007), Silva (2000) e Mata (1997) e a categoria Educação profissional por: Freire (1977), Delors (1998), Morin (2004), Sarup (1980), Kunzer (1991), Saviani (1983), PNUD (2015), Casalis (2007), Frigotto (2001), Canali (2016), Carvalho (2003), Castioni (2010), Saul \& Freitas (2007), Frigotto (2001), Pochmann (2004).

Inclusão social: a inclusão social é prioridade deste trabalho, uma vez que o estudo busca verificar se as ações de qualificação empreendidas pelo MTur, por meio do Pronatec Turismo, possibilitaram a inclusão social dos seus egressos. 
Entendendo-se que a inclusão dos sujeitos é determinante para uma vida ativa e o equilíbrio das oportunidades na sociedade, considerando que essa inclusão prioritariamente começa pelo acesso ao emprego qualificante, possibilitador do crescimento profissional, espaço onde o trabalhador possa criar, desenvolver-se e ter suas individualidades respeitadas. (CASALI, 2007; PNUD, 2015).

Para que uma sociedade se desenvolva plenamente e evite as distorções sociais comuns nos processos da lógica do capital e da mercantilização de tudo, é necessária a efetiva inclusão social, que trata de atenuar as diferenças sociais por meio do acesso aos direitos sociais, políticos, civis, econômicos, culturais e ao lazer. A configuração desses direitos se dá por meio de iniciativas governamentais, nas quais se priorizam ações que possam potencializar os fatores inerentes à inclusão social, tais como: emprego, entendida como a primeira ação capaz de efetivar a inclusão das pessoas, seja pelo trabalho autônomo ou heterônomo, desde que possibilite tanto o atendimento das necessidades vitais (moradia, alimentação, saúde) como também proporcione o desenvolvimento dos trabalhadores e a participação plena nos processos de trabalho, de modo consciente, crítico, criativo.

Neste contexto o trabalho se constitui em um espaço de relação social, no qual surgem embates, conflitos e formação, espaços esses em constante mutação devido à própria dinâmica das relações sociais que ali interagem. (SAUL; FREITAS, 2007).

Ao se potencializar o emprego outros fatores correlatos como o acesso a bens e serviços, ao lazer, a qualificação social, justiça social, segurança, a aprendizagem permanente por meio do trabalho se intensificam. Neste contexto a educação profissional é essencial, mas essa deve estar ancorada em um processo de formação integral dos sujeitos, que busque desenvolver as competências para uma vida plena em sociedade, ou seja, competências individuais, socioculturais e históricas, incluídas também as necessárias para o trabalho, mas não de forma reduzida para atender às necessidades do processo de produção que se apresenta fragmentado, dissociando o pensar do executar (SAUL; FREITAS 2007; CASTIONI, 2010).

O processo construtivo de uma educação emancipatória e cidadã reconhece que as competências profissionais procedem dos itinerários e percursos percorridos 
pelos trabalhadores, considerando as experiências adquiridas em sociedade, no trabalho e na trajetória escolar, reconhecendo que elas são resultados do contexto sociocultural em que os sujeitos estão inseridos.

No contexto do Turismo, como atividade ou como setor de serviços, existe a capacidade concreta de gerar a inclusão social, tanto do turista como do trabalhador, pois como já foi dito um dos fatores de inclusão é o acesso ao lazer e ao históricocultural que são características intrínsecas ao Turismo, por outro lado a demanda por serviços precisa de pessoas para a execução das tarefas inerentes ao planejamento, gestão e operacionalização, assim constitui-se de um setor importante para efetivar a inclusão, tanto pelo trabalho, por meio da interação entre colegas de trabalho, empregadores e turistas, como pelo lazer enquanto atividade turística. Essas relações ocorridas no campo do trabalho, quando positivas proporcionam a sensação de pertencimento social, autoestima, autorrealização, conhecimento e aprendizado constante.

Desenvolvimento humano: utilizando como referência a teoria que embasa este estudo infere-se que um dos requisitos fundamentais para o desenvolvimento humano é a formação integral dos sujeitos, que tenham como objetivo a cidadania, a liberdade, a autonomia e a emancipação (Freire, 1977, 1996; Frigotto, 2001; Gentilli; Frigotto, 2000; Kunzer, 1991; Saviani, 1983). O outro requisito é o trabalho, não aquele que aliena os sujeitos por ser centrado em atividades repetitivas e fragmentadas, mas o que admita a participação e a construção do processo de planejamento e execução das tarefas pelo trabalhador, que valorize as suas competências individuais e proporcione a construção do conhecimento pelo aprendizado inerente ao processo de trabalho.

É inerente ao desenvolvimento humano a cidadania, que corresponde ao âmbito civil, político e social, responsáveis pela liberdade individual, participação e bem-estar econômico, direitos garantidos na Constituição Federal a todos os brasileiros, entretanto na prática somente uma parcela da população consegue acessar plenamente esses direitos e exercer sua cidadania. 
Decorre desses direitos o ingresso ao trabalho, o acesso à aposentadoria, à segurança, à habitação, à educação e ao direito à cultura e ao lazer essencial para a consolidação da cidadania. (SILVA, 2000; GASTAL; MOESCH, 2007).

Verifica-se que o Turismo pode proporcionar o desenvolvimento dos sujeitos, pois possui condições para ofertar um trabalho digno e uma maior participação cidadã, por ser um setor onde as relações sociais entre trabalhadores e turistas acontecem frequentemente gerando trocas culturais, conhecimentos e aprendizados diários.

Para tanto, é fundamental que os processos educativos/formativos sejam abrangentes e não apenas centrados em procedimentos de aprendizado bancário, no qual os sujeitos quando absorvem os conhecimentos, muitas vezes nem sequer conseguem transmutá-los para sua realidade. A educação profissional deve ser integral problematizadora, ou seja, permitir aos sujeitos não apenas executar tarefas e desenvolver competências e habilidades básicas para o trabalho, mas ter uma consciência crítica sobre a dinâmica do trabalho, para que possam interagir e tomar decisões que assegurem o bom desempenho e o seu desenvolvimento profissional e humano.

Para isso a educação deve trabalhar também com os saberes adquiridos ao longo da vida, respeitando os fatores histórico-cultural e social dos sujeitos, integrando-os aos processos educativos. Possibilitando a construção/reconstrução do conhecimento pelos indivíduos, bem assim ensinar a visão global e local do mundo, aprender o objeto em seu contexto, complexidade e conjunto, transmitir as ideias essenciais para a construção de um cidadão participativo, que entenda e respeite as diferenças. (MORIN, 2001; PNUD, 2015).

$\mathrm{O}$ desenvolvimento assegura aos sujeitos manifestar suas potencialidades $\mathrm{e}$ talentos no trabalho, em família e sociedade, contribuindo para a felicidade e autorrealização e bem-estar social atrelado à qualidade e não apenas a quantidade, é potencializador da cidadania e da inclusão social, pela equalização de oportunidades em decorrência da cidadania. (SACHS, 2008; DEMO, 1994). 


\section{Educação Profissional possibilitadora da construção de carreiras:}

As concepções de qualificação profissional remetem primordialmente às necessidades do mundo do trabalho e ao desenvolvimento socioeconômico, são destinadas aos indivíduos (trabalhadores) para a aquisição, por vias formais e ou informais, por meio de instrução e ou experiência prática, das competências conhecimentos, habilidades e atitudes, assim como obter seu reconhecimento, o que Ihes permitiria melhorar sua posição ocupacional e social (SAUL; FREITAS. 2007; OLIVEIRA, 2013).

Aborda, ainda, sobre os saberes construídos, compartilhados, adquiridos, transmitidos, disputados, apropriados, integrados, segmentados e regulados, referidos ao mundo das relações de trabalho nas sociedades capitalistas. (IVO et, al, 2013).

A formação profissional no sentido lato é mais abrangente, ao identificar-se com escolarização, uma vez que visa não só a organização e desenvolvimento das competências para o trabalho, como também para a vida. Requer um patamar sempre mais complexo da capacidade de abstração do conjunto da força de trabalho, quer ela realize tarefas simples ou complexas no mundo da produção ou assuma responsabilidades sócio-político-culturais na organização de seu cotidiano. (NEVES, 1997, p. 23).

Nos países capitalistas desenvolvidos a formação profissional no sentido lato significa a atualização técnico-político e cultural, pois, na fase monopolista do capital, a formação profissional já era de natureza científico-tecnológica, o que não aconteceu no Brasil, pois este manteve a grande maioria dos trabalhadores excluídos do acesso à formação científica tecnológica. (NEVES, 1997).

Para que seja possível alcançar um nível de formação científico-tecnológico, primeiramente, devem-se resolver problemas quantitativos e qualitativos; os quantitativos referem-se ao acesso à escola dos excluídos do sistema educacional e o qualitativo ao acesso universalizado à educação de natureza científico-tecnológico. Entende-se, então, que não basta o acesso à escola; esta escola precisa estar redefinida, dando condições ao acesso ao conhecimento científico-tecnológico e a formação emancipatória e cidadã. (NEVES, 1997). 
Já a formação profissional no sentido estrito, o entendimento proposto é de que seria o ramo do sistema educacional, destinado à atualização técnico-política e cultural permanente da força de trabalho escolarizada, após o seu engajamento no mundo da produção. (NEVES, 1997, p. 25).

Percebe-se que no Brasil, o acesso à educação profissional (qualificação/formação lato) ainda é deficitário, o que vigora é a educação no sentido estrito, ou seja, destinada ao treinamento da mão-de-obra necessária à execução de tarefas simples e operacionais para atender os setores produtivos, tarefas que não demandam o domínio de fundamentos científicos tecnológicos para a sua execução. Nessas tarefas o pensar e o executar estão separados, os trabalhadores são preparados apenas para executar atividades fragmentadas e isoladas.

No setor de turismo essa concepção de educação profissional é recorrente uma vez que as ações de qualificação são fragmentadas e setorizadas, os profissionais atuam apenas na sua área específica de modo mecanizado e padronizado, não conseguem ter autonomia para resolver pequenas questões que fujam do manual e tampouco entender o significado do Turismo, o contexto em que ele se desenvolve e as implicações sociais e culturais abrangidas nessa relação entre turistas e trabalhadores.

Ao se propor ações de educação profissional com foco apenas nas demandas do mercado não se dá a devida importância à formação dos trabalhadores de turismo e hospitalidade, relegando totalmente o desenvolvimento humanizador pelo trabalho e a possibilidade para construção de carreiras. Ao contrário, os profissionais do setor, na maioria das vezes, sentem-se inferiorizados por estarem prestando serviços aos turistas, devido à percepção do servilismo que esta enraizada na mentalidade histórico-cultural dessas pessoas.

Neste contexto esses sujeitos não conseguem estabelecer uma troca enriquecedora, ao contrário acabam por intensificarem um sentimento de despertencimento (processo psíquico no qual surge a impressão de que se é estranho a si mesmo, de que o sentir e o agir carecem de participação ativa, efetuando-se de modo quase automático) e uma visão de que a prestação de serviço é inferiorizante e desmotivante, reduzindo o potencial do Turismo em 
proporcionar trabalho digno, motivante, com constante aprendizado e trocas culturais e possibilitador de construção de carreiras.

É de suma importância definir novas concepções para a Política publica de educação/formação profissional, focada nos sujeitos e não apenas na produção e no capital. Em que sejam valorizadas as potencialidades humanas. Com uma nova postura na educação profissional será possível enxergar o trabalho no Turismo como oportunidade interessante, gratificante e criativa, no qual os sujeitos podem desenvolver-se permanentemente pelas relações de troca e aprendizado constante que o setor pode proporcionar. Pela formação de um profissional ativo, crítico, consciente e participativo poderá se mudar a visão empresarial e lutar pela valorização e o reconhecimento profissional. 


\section{CAPÍTULO 3: A INCLUSÃO SOCIAL DE JOVENS E ADULTOS PELA EDUCAÇÃO PROFISSIONAL EM TURISMO E HOSPITALIDADE}

O terceiro capítulo reconstrói a análise dialética proposta nessa dissertação por meio das categorias operatórias do Materialismo Histórico Dialético, permitindo identificar as contradições entre a teoria (discursos oficiais expostos pelos documentos) e a prática (efetivação da política de qualificação profissional relatada pelos gestores e egressos). Método que possibilitou dialogar com a realidade da política de qualificação PRONATEC Turismo ao evidenciar as relações estabelecidas pelos sujeitos (setor público, privado, profissionais, egressos e empresários) na produção da materialidade da ação formativa. Possibilitando entender a ideologia presente na política oficial de qualificação em Turismo e os limites e possibilidades para inclusão social de jovens e adultos no mundo do trabalho formal do Turismo e hospitalidade. Síntese dialética expressa nesse terceiro capítulo.

Esse processo comportou uma pesquisa avaliativa sobre a relação teoria $\mathrm{e}$ prática, como desvelamento das contradições existentes utilizando-se como referência as categorias operatórias de análise a priori tais como: matéria, práxis, historicidade, teoria/prática, totalidade/fragmentação, contradição/mediação, objetividade/subjetividade, autonomia/dependência, criticidade/alienação e as categorias a posteriori: inclusão social, desenvolvimento humano e educação profissional possibilitadora de construção de carreiras, que foram determinantes para identificar se os cursos executados pelo Programa puderam ter resultados efetivos para o desenvolvimento dos sujeitos participantes e consequentemente desenvolvimento endógeno do setor.

Ao longo deste estudo percorreu-se a trajetória das Políticas Públicas de educação profissional implementadas no País no limiar e início do século XXI até a atualidade, tais como o PLANFOR e o PNQ, ambos de responsabilidade do Ministério do Trabalho e Emprego, que naquele momento era o Órgão público que concentrava a maior responsabilidade na qualificação profissional dos trabalhadores em articulação com o Ministério da Educação.

A partir de 2003, com a criação do Ministério do Turismo, a qualificação profissional para o setor passou a ser um dos temas sob sua responsabilidade, que 
em sua composição abarcou o Departamento de Qualificação, responsável pela implementação do PRONATEC Turismo, objeto desta pesquisa.

\subsection{O PRONATEC TURISMO LIMITES E POSSIBILIDADES COMO POLÍTICA DE INCLUSÃO SOCIAL PELA QUALIFICAÇÃO EM TURISMO E HOSPITALIDADE}

Esta análise transcorrerá sobre a matéria e a práxis da implantação da política pública de qualificação profissional em turismo, PRONATEC Turismo, compreendendo que o espaço e o tempo resultam na matéria, e, que a execução desta Política compõe-se desta, pois expressa-se no tempo e no espaço, compreendido entre 2011-2015, nas cidades sedes da Copa do Mundo de Futebol FIFA 2014, configurando as nuances de um sistema social tecido nesses territórios. (MOESCH, 2002).

A práxis deste processo se dinamiza por contradições, conforme será explanado neste tópico, cuja superação o conduz a patamares de crescente complexidade, nos quais novas contradições impulsionam a outras superações na relação teoria-prática. (PAULO NETTO, 2011).

Ao buscar compreender as tramas ocorridas no espaço e no tempo da implantação e execução do Programa, pelo Ministério do Turismo, utilizou-se da análise documental a partir de Cellard, "a análise documental permite acrescentar a dimensão do tempo à compreensão do social, graças aos documentos pode-se operar um corte longitudinal que favorece a observação do processo de maturação ou de evolução de grupos". (CELLARD, 2008, p. 295).

Recorreu-se, também, a análise de conteúdo, para buscar desvelar o objeto desta pesquisa e as inquietações inerentes a ela, uma vez que os sujeitos arrolados são parte fundamental deste processo. A metodologia foi utilizada por meio de entrevistas com os atores sociais que participaram do Programa, como resultados de discursos diversificados, baseados na dedução e na inferência podem-se aferir significados ao objeto desta pesquisa. (BARDIN, 2011). Os achados da análise de conteúdo a partir das categorias a priori do (MHD) serão analisadas a luz das teorias de desenvolvimento humano, educação profissional e inclusão social, numa relação dialética. 
Visando uma maior compreensão da historicidade e da práxis que envolveu a execução do PRONATEC Turismo, pelas técnicas de pesquisas utilizadas, por meio das categorias da dialética buscou-se o desvelar do objeto desta pesquisa e elucidar os objetivos que seguem:

- Identificar a relação do Programa, no período de 2012-2015, em relação às Atividades Características do Turismo (ACTs) e cursos de profissionalização correlatos.

- Analisar a relação entre a empregabilidade no período dos megaeventos esportivos e a inclusão social de jovens e adultos, egressos do PRONATEC Turismo, nas cidades sedes.

- Identificar a correlação entre as tipologias de cursos ofertados pelo PRONATEC Turismo às necessidades de demanda de trabalhadores das cidades sedes.

- Verificar se o PRONATEC Turismo possibilitou a construção de carreiras profissionais aos seus egressos no setor de turismo e hospitalidade?

- Analisar se a formação profissional do PRONATEC Turismo foi possibilitadora do desenvolvimento humano dos seus egressos e consequente inclusão social.

Para atingir a totalidade de um processo de educação profissional deve-se trabalhar com os pressupostos de inclusão social e desenvolvimento humano, já que um processo de educação integral deve oferecer prerrogativas para que os sujeitos possam galgar o desenvolvimento pela educação e pelo trabalho no setor de turismo e hospitalidade e a consequente inclusão social.

Tem-se como premissas das políticas públicas primordiais para 0 desenvolvimento humano e social do país as políticas educacionais, componentes das políticas públicas sociais, que visam uma maior qualidade de vida para a sociedade, tendo em vista que a educação consiste de ferramenta capaz de elevar a autoestima dos cidadãos e proporcionar a sua autonomia como ser social. (PARENTE, 2010).

Ao se potencializar o desenvolvimento humano pela educação e pelo trabalho se estimula também a inclusão social, pessoas preparadas e inseridas em um mercado de trabalho digno têm condições de se projetarem socialmente e de 
acompanharem as crescentes mudanças e transições do mundo do trabalho e da sociedade em geral. Como consequência utilizam o seu potencial criativo, crítico e participativo, operacionalizando a cidadania nos âmbitos civil, político e social.

[ ] a cada um destes elementos corresponde um conjunto de direitos. A saber, a cidadania civil é formada pelos direitos necessários à liberdade individual; a cidadania política pelos direitos de participação no exercício do poder político; e a cidadania social pelo conjunto de direitos, que inclui segurança e bem-estar econômico, o direito de compartilhar a riqueza socialmente produzida e o de viver uma vida civilizada, segundo os padrões sociais vigentes. (SILVA, 2000, p.127)

Complementa esse raciocínio o que traz Gastal; Moesch (2007, p. 31) "o pleno exercício da cidadania supõe direitos civis, direitos políticos [...] e direitos sociais (regulação do trabalho, aposentadoria, alimentação, habitação, saúde e educação) e direitos culturais". Infere-se que para obtenção de uma vida digna, inclui-se entre esses preceitos o direito ao lazer, essencial para a consolidação da cidadania. Nesse sentido o turismo interage com esses direitos sob dois pontos de vista: o do turista e o do trabalhador do setor, tendo em vista que o lazer é a principal motivação do turismo e que as condições para um trabalho digno fazem parte das necessidades dos trabalhadores; o profissional do setor deve estar apto a atender às necessidades dos turistas, mas para isso ele precisa estar inserido em um processo de trabalho que lhe garanta o desenvolvimento humano e cidadão pelo turismo, possibilitando a inclusão social.

Esse processo de inclusão é inerente à sociedade que busca na educação e no trabalho as oportunidades para essa concretização. De acordo com a UNESCO, 1998 uma educação que proporcione a aprendizagem e o conhecimento deve atuar em torno de quatro aprendizagens ao longo da vida: aprender a conhecer, aprender a fazer, aprender a viver juntos e aprender a ser; premissas que possibilitam uma educação cidadã e emancipatória para preparar os sujeitos para compreender o mundo, desenvolver suas capacidades profissionais e comunicar; para colocar em prática os conhecimentos adquiridos; para participar e cooperar em sociedade; e, finalmente para desenvolver sua personalidade e agir com autonomia, discernimento e reponsabilidade. 
Visando estabelecer um nexo do que se verifica atualmente em relação à educação profissional (ínfimo processo de inclusão social e desenvolvimento humano) buscou-se uma retrospectiva breve sobre a educação para o trabalho, verificando que foi concebida para atender a expansão industrial no início do século $X X$, viabilizando um sistema de ensino paralelo ao da educação regular, o qual se propunha a preparação dos pobres, marginalizados para atuarem no sistema produtivo nas funções técnica de baixo e médio nível da hierarquia ocupacional. (KUENZER, 1991).

Com base neste histórico se evidencia a dicotomia na concepção da educação regular, em detrimento da educação profissional, na qual a escola, em regra, busca uma preparação distinta da sociedade, os mais pobres devem estar aptos para ocuparem cargos operacionais e técnicos e a classe dominante competem os cargos especializado, científicos e acadêmicos, relegando a educação profissional um papel meramente produtivo. Conforme aponta Saviani, 1983 a escola é determinada socialmente; a sociedade se estabeleceu no modo de produção capitalista, foi dividida em classes com interesses opostos; logo, a escola sofre a determinação do conflito de interesses que caracteriza a sociedade. Assim a política de educação profissional proposta atua como paliativa frente aos problemas sociais, de modo a se manter o domínio. Se fazendo presente nas falas dos sujeitos entrevistados, conforme segue:

"PRONATEC copa tinha como objetivo inserir pessoas no mercado de trabalho" (gestor g); "inserção de grupos menos favorecidos na qualificação para a empregabilidade" (professor h); "ao final do curso tivemos uma atividade prática, mas não acho que tenha gerado desafios suficientes" (egresso k). Identifica-se nestes discursos a aproximação da teoria com a prática ao se conferir que um dos objetivos da política pública de educação profissional é a preparação dos sujeitos, especialmente de grupos menos favorecidos, para o mercado de trabalho (qualificação para a empregabilidade), na qual o treinamento prático é muito valorizado.

Notadamente as linhas de atuação do PRONATEC Turismo definidas pelos o MTur para a Copa do Mundo de Futebol Fifa 2014 foram: 
(I) PRONATEC Copa na Empresa: instituído para os empresários e trabalhadores que atuam na cadeia produtiva do turismo. Com a finalidade de aperfeiçoar $^{44}$ os profissionais que trabalham no setor turístico com cursos ministrados, preferencialmente, no próprio local de trabalho e em horários compatíveis com as atividades desempenhadas pelos colaboradores da empresa.

(II) PRONATEC Copa: qualificação profissional para suprir necessidades de mão de obra do setor $^{45}$ de turismo em cada um dos municípios participantes do Pronatec Turismo; e

(III) PRONATEC Copa Social: qualificação de jovens em situação de vulnerabilidade $^{46}$, visando promover sua inserção no mercado de trabalho do turismo, em parceria com o Serviço Social da Indústria (Sesi), no âmbito do Projeto ViraVida.

Diante do exposto, configura-se a totalidade/fragmentação dessa política uma vez que o acesso ao emprego qualificante e digno ${ }^{47}$ constitui-se condição essencial para a inclusão social, entretanto, quando a política pública se apresenta de forma fragmentada, para atender uma demanda específica (mercado), esta coloca no sujeito a responsabilidade de se manter empregável.

"Buscou-se atender as necessidades do mercado" (professor i); "O público em cada um dos municípios foi identificado pelas secretarias estaduais e municipais de Turismo, nas 12 cidades sede, juntamente com empresários e associações representativas do setor". (APÊNDICE A).

Coaduna com essa ideia o que dispõe o PNT (2007, p. 30) "O fomento ao aumento da competitividade dos destinos turísticos e a melhoria da qualidade dos serviços ofertados devem ser prioridades por meio da qualificação profissional e incremento dos produtos e serviços em todos os elos da cadeia produtiva do setor". Alocou-se na qualificação um importante papel para a organização dos destinos turísticos, dentro de um padrão internacional de mercado, ideia que prevalece nos outros dois Planos (2003 e 2013).

\footnotetext{
${ }^{44}$ Grifo nosso

${ }^{45}$ Grifo nosso

${ }^{46}$ Grifo nosso

${ }^{47}$ Ver os 4 pilares do trabalho digno (PNUD, 2015)
} 
Com base no levantamento dessas demandas foi possível elaborar o quadro 8, que apresenta a demanda, a oferta e o número de concluintes no período 20122015 (quando efetivamente os cursos foram executados) nota-se a oferta superou a demanda, mas, não houve correlação entre as tipologias de cursos ofertados às necessidades de demanda dos trabalhadores das cidades sedes.

Quadro 8- Demanda e Oferta e Concluintes Cursos PRONATEC Turismo

\begin{tabular}{|c|c|c|c|c|}
\hline Município & Curso & Demanda & Oferta & Concluintes \\
\hline \multirow{6}{*}{ Brasília } & Agência de Viagem & 138 & 67 & 162 \\
\hline & Alimentação & 1180 & 1206 & 600 \\
\hline & Alojamento & 1017 & 1977 & 327 \\
\hline & Cultura e lazer & 542 & 374 & 162 \\
\hline & Eventos & 1211 & 1152 & 469 \\
\hline & Outros & 5131 & 11292 & 6019 \\
\hline \multirow{6}{*}{ Cuiabá } & Agência de Viagem & - & - & 305 \\
\hline & Alimentação & 385 & 1376 & 850 \\
\hline & Alojamento & 326 & 1243 & 589 \\
\hline & Cultura e lazer & 253 & 616 & 305 \\
\hline & Eventos & 417 & 1173 & 588 \\
\hline & Outros & 1080 & 14620 & 8196 \\
\hline \multirow{6}{*}{ Fortaleza } & Agência de Viagem & 150 & - & 267 \\
\hline & Alimentação & 1010 & 1851 & 1214 \\
\hline & Alojamento & 928 & 1152 & 901 \\
\hline & Cultura e lazer & 394 & 267 & 268 \\
\hline & Eventos & 736 & 683 & 683 \\
\hline & Outros & 2450 & 2136 & 2387 \\
\hline \multirow{6}{*}{ Recife } & Agência de Viagem & 325 & - & 344 \\
\hline & Alimentação & 1220 & 519 & 342 \\
\hline & Alojamento & 670 & 838 & 322 \\
\hline & Cultura e lazer & 760 & 489 & 344 \\
\hline & Eventos & 790 & 603 & 362 \\
\hline & Outros & 2785 & 2011 & 1080 \\
\hline \multirow{6}{*}{ Natal } & Agência de Viagens & - & 52 & 216 \\
\hline & Alimentação & 511 & 1195 & 752 \\
\hline & Alojamento & 572 & 2144 & 641 \\
\hline & Cultura e lazer & 252 & 310 & 222 \\
\hline & Eventos & 420 & 419 & 353 \\
\hline & Outros & 843 & 5639 & 3882 \\
\hline
\end{tabular}




\begin{tabular}{|c|c|c|c|c|}
\hline Município & Cursos & Demanda & Oferta & Concluintes \\
\hline \multirow{6}{*}{ Salvador } & Agência de viagem & & & 95 \\
\hline & Alimentação & 1059 & 2191 & 1368 \\
\hline & Alojamento & 2281 & 3347 & 1356 \\
\hline & Cultura e lazer & & 284 & 142 \\
\hline & Eventos & 815 & 2115 & 1167 \\
\hline & Outros & 3512 & 7588 & 5464 \\
\hline \multirow{6}{*}{ Manaus } & Agência de Viagem & 100 & - & 2 \\
\hline & Alimentação & 827 & 420 & 269 \\
\hline & Alojamento & 928 & 463 & 156 \\
\hline & Cultura e lazer & 307 & 54 & 86 \\
\hline & Eventos & 1076 & 565 & 357 \\
\hline & Outros & 448 & 4488 & 2933 \\
\hline \multirow{6}{*}{ Curitiba } & Agência de Viagens & - & - & 10 \\
\hline & Alimentação & 469 & 499 & 187 \\
\hline & Alojamento & 40 & 470 & 89 \\
\hline & Cultura e lazer & 85 & 45 & - \\
\hline & Eventos & 140 & 386 & 149 \\
\hline & Outros & 1463 & 3686 & 1777 \\
\hline \multirow{6}{*}{ Porto Alegre } & Agência de Viagem & 30 & - & 2 \\
\hline & Alimentação & 296 & 1448 & 758 \\
\hline & Alojamento & 153 & 931 & 336 \\
\hline & Cultura e lazer & 60 & 17 & 8 \\
\hline & Eventos & 321 & 959 & 488 \\
\hline & Outros & 5584 & 8088 & 3890 \\
\hline \multirow{6}{*}{ São Paulo } & Agência de Viagem & 119 & - & 34 \\
\hline & Alimentação & 1280 & 1347 & 753 \\
\hline & Alojamento & 829 & 1302 & 141 \\
\hline & Cultura e lazer & 433 & 116 & - \\
\hline & Eventos & 1070 & 895 & 344 \\
\hline & Outros & 5534 & 9551 & 5110 \\
\hline \multirow{6}{*}{ Rio de Janeiro } & Agência de Viagem & - & - & 61 \\
\hline & Alimentação & 2613 & 3714 & 638 \\
\hline & Alojamento & 2396 & 2735 & 379 \\
\hline & Cultura e lazer & 874 & 741 & - \\
\hline & Eventos & 1752 & 2420 & 263 \\
\hline & Outros & 5608 & 4478 & 1890 \\
\hline
\end{tabular}




\begin{tabular}{|c|l|c|c|c|}
\hline Município & \multicolumn{1}{|c|}{ Curso } & Demanda & Oferta & Concluintes \\
\hline \multirow{5}{*}{ Belo Horizonte } & Agência de Viagem & & & 161 \\
\cline { 2 - 5 } & Alimentação & 278 & 362 & 171 \\
\cline { 2 - 5 } & Alojamento & 353 & 926 & 242 \\
\cline { 2 - 5 } & Cultura e lazer & 405 & 272 & 102 \\
\cline { 2 - 5 } & Eventos & 430 & 595 & 337 \\
\cline { 2 - 5 } & Outros & 4637 & 6813 & 3001 \\
\hline \multicolumn{2}{|c|}{ TOTAL GERAL } & $\mathbf{7 5 1 0 1}$ & $\mathbf{1 2 9 7 1 5}$ & $\mathbf{6 7 8 6 8}$ \\
\hline
\end{tabular}

Fonte: Elaborado pela pesquisadora com base nos documentos do MTur (2016)

Conforme os dados fica explicita a alta taxa de evasão ocorrida nos cursos, no período de referência, elementos que também aparecem nas falas dos envolvidos no processo: "no PRONATEC copa na empresa houve muita evasão, porque os funcionários eram solicitados a todo momento, assim se desmotivavam em continuar o curso [...] algumas turmas começavam com 30 e terminavam com 8 ou 3 participantes" (professor j); "evasão devido à falta de repasso das bolsas" (egresso I); "achamos que a evasão foi menor porque realizamos os cursos na própria comunidade" (gestor $h$ ).

A objetividade/subjetividade encontrada nessas realidades é inerente às condições objetivas dadas externamente ao homem, ou dadas sem sua opção própria, enquanto as condições subjetivas aquelas dependentes da opção humana, a capacidade de construir a história em parte no contexto das condições objetivas ficou demonstrado na fala do gestor $h$ em relação à adequação do curso as necessidades da comunidade local que promoveu a diminuição da evasão.

Tem-se nesse processo de implementação do Programa uma condição dada, os cursos de qualificação destinados ao setor de turismo e hospitalidade, formatados de modo genérico, para atender uma demanda pontual (Copa do Mundo de Futebol FIFA 2014), no entanto, os sujeitos envolvidos podem fazer a diferença quando se portam de forma mais ativa frente à vida e conseguem mudar o rumo préestabelecido.

Outro fator aponta que as instituições de formação profissional movimentam volumes consideráveis de recursos voltados, principalmente, para oferta de cursos 
FIC, na sua maior parte, com caráter meramente de qualificação profissional, mantendo-se metodologias ultrapassadas para atender as demandas atuais.

\begin{abstract}
Há, porém um nó crítico que pode inviabilizar a estratégia de qualificar grandes contingentes de trabalhadores: a inexistência de metodologia e de conteúdo programático adequados às necessidades do mercado e à demanda dos trabalhadores por um processo educativo que não fique circunscrito apenas à qualificação profissional, e que thes possibilite a continuidade dos estudos. (ALVES; VIERA, 1995, p.131).
\end{abstract}

Ao confrontar essas falas com alguns planos dos cursos executados no PRONATEC Turismo, quadro 9 abaixo, nota-se que os conteúdos primaram, em sua maioria, para aquisição de competências, habilidades e atitudes condizentes com as ocupações e as necessidades pontuais do mercado de turismo e hospitalidade, enquanto que conteúdos transversais com foco na formação integral dos sujeitos, que Ihes possibilitasse o desenvolvimento humanizador pelo turismo, foram pouco empreendidos.

Empresários do setor de turismo e hospitalidade, que possuam uma visão inovadora de negócios, aceitam, estimulam e até patrocinam o treino técnico ${ }^{48}$ do seu empregado, no entanto, recusam a formação, que envolve o saber técnico e científico indispensável ao trabalhador que pode proporcionar a sua autonomia no mundo. "Transformar a experiência educativa em puro treinamento técnico é amesquinhar o que há de fundamentalmente humano no exercício educativo: o seu caráter formador". (FREIRE, 1996 p. 37).

Deduz-se na práxis da política pública de qualificação profissional, PRONATEC Turismo, que os cursos primaram pelo desenvolvimento de competências técnicas e habilidades básicas das ocupações, carecendo de um processo virtuoso que articulasse a educação profissional com a educação básica, de modo a proporcionar uma formação emancipatória e cidadã para uma maior profissionalização e desenvolvimento dos trabalhadores.

\footnotetext{
${ }^{48}$ Grifo nosso.
} 


\begin{tabular}{|c|c|c|c|c|}
\hline \multicolumn{5}{|c|}{ Cursos de Qualificação } \\
\hline $\begin{array}{l}\text { Cursos de } \\
\text { Qualificação }\end{array}$ & \multicolumn{4}{|c|}{ Grade curricular - Guia FIC } \\
\hline Garçom & \begin{tabular}{|l|} 
INSTITUTO \\
FEDERAL \\
ENSINO \\
FUNDAMENTAL \\
COMPLETO \\
1. Técnicas de \\
Sala e Copa \\
2.Técnicas de \\
Bar e Vinhos \\
3.Higiene e \\
manipulação de \\
alimentos \\
4.Responsabilida \\
de ambiental \\
5.Sociedade e \\
Trabalho \\
TOTAL 200 \\
horas \\
\end{tabular} & $\begin{array}{l}\text { SENAC } \\
\text { ENSINO } \\
\text { FUNDAMENTAL } \\
\text { COMPLETO } \\
\text { 1. Fundamentos de } \\
\text { turismo, gastronomia e } \\
\text { hospitalidade } \\
\text { 2. Saúde e segurança } \\
\text { no trabalho } \\
\text { 3. Fundamentos } \\
\text { técnico-científicos da } \\
\text { cambuza } \\
\text { 4. Fundamentos } \\
\text { técnico-científicos do } \\
\text { trabalho do garçom } \\
\text { 5. Prática } \\
\text { supervisionada } \\
\text { TOTAL } 250 \text { horas } \\
\end{array}$ & $\begin{array}{l}\text { SENAC } \\
\text { ENSINO } \\
\text { FUNDAMENTAL } \\
\text { COMPLETO } \\
\text { 1.Postura } \\
\text { Profissional e } \\
\text { Organização do } \\
\text { Trabalho } \\
\text { 2. Boas Práticas de } \\
\text { Higiene } \\
\text { 3.Teoria e Técnicas } \\
\text { de Trabalho do } \\
\text { Garçom } \\
\text { 4. Prática Profissional } \\
\text { Supervisionada } \\
\text { TOTAL } 250 \text { horas }\end{array}$ & \\
\hline $\begin{array}{l}\text { Auxiliar de } \\
\text { confeitaria }\end{array}$ & $\begin{array}{l}\text { 1. Segurança e } \\
\text { organização do } \\
\text { trabalho } \\
\text { 2. Segurança } \\
\text { alimentar e do } \\
\text { alimento } \\
\text { 3. Comunicação, } \\
\text { expressão e } \\
\text { ética profissional } \\
\text { 4. Habilidades } \\
\text { Básicas de } \\
\text { cozinha } \\
\text { profissional } \\
\text { TOTAL } 180 \\
\text { horas }\end{array}$ & $\begin{array}{l}\text { 1. Inglês Básico } \\
\text { 2. Saúde e Segurança } \\
\text { no Trabalho } \\
\text { 3. Legislação aplicada } \\
\text { ao segmento alimentício } \\
\text { 4. Microbiologia dos } \\
\text { alimentos } \\
\text { 5. Métodos de } \\
\text { Conservação de } \\
\text { produtos de origem } \\
\text { Animal e vegetal } \\
\text { 6. Higiene e Segurança } \\
\text { Alimentar } \\
\text { 7. Aproveitamento dos } \\
\text { resíduos da cozinha } \\
\text { 8. Higiene e sanitização } \\
\text { da área de Produção } \\
\text { 9. Boas Práticas de } \\
\text { Fabricação - BPF } \\
\text { TOTAL } 160\end{array}$ & $\begin{array}{l}\text { 1.Integração e } \\
\text { Orientação } \\
\text { Profissional } \\
\text { 2.Matemática Básica } \\
\text { 3.Português Básico } \\
\text { 4.Saúde e Segurança } \\
\text { no Trabalho } \\
\text { 5.Higiene e } \\
\text { Segurança Alimentar } \\
\text { 6.Preparação e } \\
\text { Conservação de } \\
\text { Alimentos } \\
\text { 7.Higiene e } \\
\text { Sanitização da área } \\
\text { de produção } \\
\text { 8.Preparação de } \\
\text { molhos, massas, } \\
\text { cremes e guarnições } \\
\text { TOTAL 250 }\end{array}$ & \\
\hline $\begin{array}{l}\text { Auxiliar de } \\
\text { cozinha }\end{array}$ & $\begin{array}{l}\text { ENSINO } \\
\text { FUNDAMENTAL } \\
\text { INCOMPLETO } \\
\text { 1. Segurança e } \\
\text { organização do } \\
\text { trabalho } \\
\text { 2. Segurança } \\
\text { alimentar e do } \\
\text { alimento }\end{array}$ & \begin{tabular}{|l|} 
ENSINO \\
FUNDAMENTAL \\
INCOMPLETO \\
1. Inglês Básico \\
2. Saúde e Segurança \\
no Trabalho \\
3. Legislação aplicada \\
ao segmento alimentício \\
4. Microbiologia dos
\end{tabular} & $\begin{array}{l}\text { 1.Integração e } \\
\text { Orientação } \\
\text { Profissional } \\
\text { 2.Matemática Básica } \\
\text { 3.Português Básico } \\
\text { 4.Saúde e Segurança } \\
\text { no Trabalho } \\
\text { 5.Higiene e } \\
\text { Segurança Alimentar }\end{array}$ & $\begin{array}{l}\text { SENAC } \\
\text { ENSINO } \\
\text { FUNDAMENTAL } \\
\text { INCOMPLETO } \\
\text { 1.Fundamentos } \\
\text { de turismo, } \\
\text { gastronomia e } \\
\text { hospitalidade } \\
\text { 2.Higiene na } \\
\end{array}$ \\
\hline
\end{tabular}




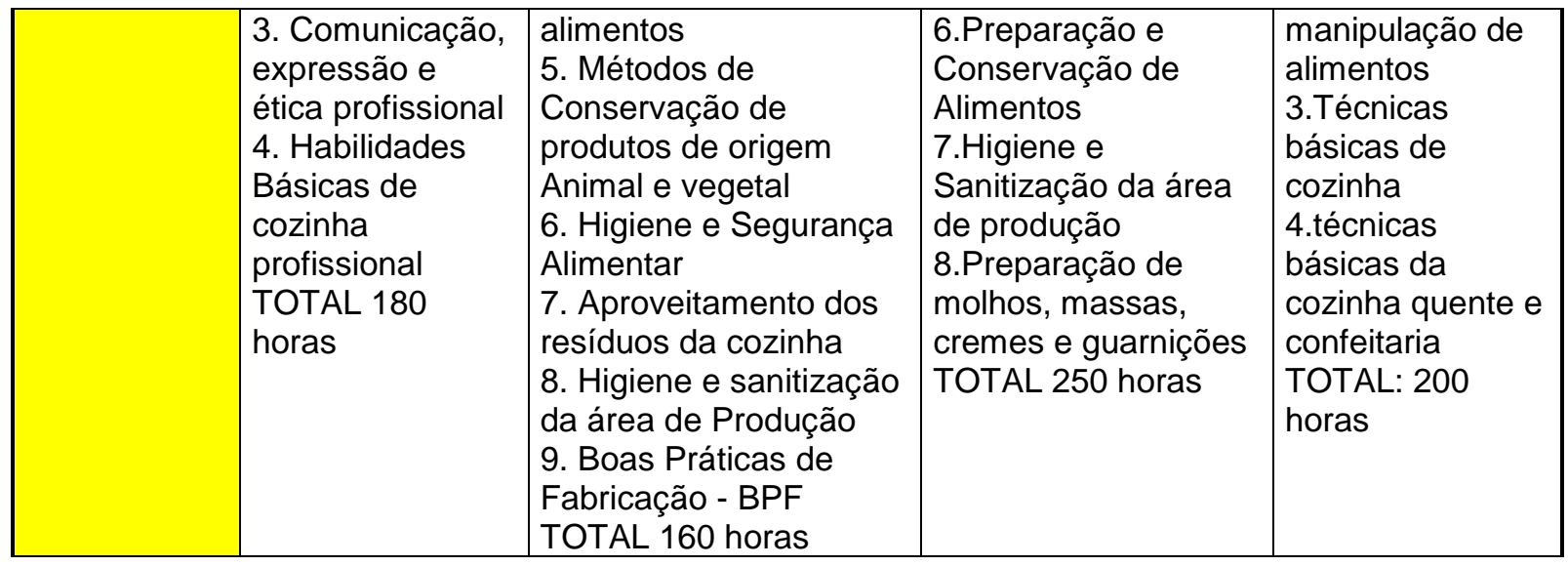

Fonte: Elaborado pela autora, 2016 com base nos planos de cursos das instituições ofrentantes do PRONATEC Turismo.

LEGENDA: conteúd os cidadania - Conteúdos Transversais

Para além dessa visão reducionista da educação profissional há um esforço de alinhar as modalidades de educação atendendo às premissas essenciais para à construção do conhecimento científico, técnico e operacional, pois, as competências e qualificações para o trabalho já estão cada vez mais avançadas ${ }^{49}$, os empregos exigem qualificações mais específicas e elevadas. A tecnologia demandará além das competências básicas, aptidões para a criatividade, a inovação e a solução de problemas. (PNUD, 2015).

Outro ponto que permeia a discussão sobre a educação profissional é a formação no local de trabalho que, frequentemente, ocorre na forma de adestramento, no qual é oferecido um aprendizado objetivo, mas, fracassado em relação à construção da autonomia, essa qualificação atua de forma imediatista não possibilitando uma formação para a emancipação dos sujeitos, por meio de um horizonte de orientação. (ADORNO,1995).

A construção de representações e saberes (habilidades técnicas, saberes sobre o ofício e sobre as relações produtivas) ocorrem durante o trabalho, que vai além da produção de bens materiais. Assim, o trabalho enquanto práxis social, numa

\footnotetext{
${ }^{49}$ No setor de turismo e hospitalidade essas inovações se fazem presentes cotidianamente, já que os turistas buscam serviços e produtos diferenciados, que lhes proporcionem uma experiência única e gratificante.
} 
relação dialética entre sujeito-objeto, envolve apropriação criadora e não simplesmente atividades de mera repetição/reprodução. (MOESCH, 2016).

Conforme identificado em campo apreende-se que os conteúdos trabalhados ficaram, muitas vezes, restritos a aquisição dos saberes para funções específicas: "conteúdo programático baseado em aula técnicas temáticas específicas nos diferentes tipos de eventos" (professor k); "os professores deveriam utilizar uma linguagem mais próxima à realidade do aluno" (egresso $\mathrm{m}$ ).

A prática de uma educação voltada ao mercado acentua a aquisição dos saberes operacionais em detrimento dos saberes para 0 desenvolvimento humanizador e social, que Morin (2001) aponta como os setes saberes necessários à educação do futuro:

1. conhecimento é uma tradução/reconstrução. Deve-se estimular a capacidade dos educandos em colocá-lo em prática no seu cotidiano;

2. princípios do conhecimento pertinente: ensinar não apenas a visão global mas, também, os conhecimentos parciais e locais; não basta ter uma visão fragmentada por disciplinas, é necessário identificar o vínculo entre as partes e a totalidade. "Apreender o objeto em seu contexto, sua complexidade, seu conjunto". (MORIN, 2001 p. 14);

3. a educação deve integrar aos processos educativos a formação física, psíquica, biológica, social, cultural e histórica do ser humano para ensinar a condição humana;

4. ensinar a identidade terrena: conhecer a realidade do mundo (processos ambientais, econômicos, ideológicos, sociais), problemas e ameaças ao planeta, buscando um entendimento comum da condição humana;

5. enfrentar as incertezas: considerar as incertezas na produção do conhecimento, nenhum conhecimento é absolutamente certo, imutável. Ensinar princípios e estratégias que permitam enfrentar os imprevistos, 0 inesperado e as incertezas e modificar seu desenvolvimento em virtude das informações adquiridas ao longo do tempo;

6. ensinar a compreensão: compreender e respeitar as diferenças para propiciar atitudes de tolerância e respeito com o outro; 
7. ética do gênero humano: educação como ferramenta de cidadania, capaz de encaminhar os indivíduos rumo a uma sociedade democrática.

A educação em turismo e hospitalidade deve proporcionar o desenvolvimento e ampliação desses saberes junto aos trabalhadores, criando subsídios para que esses profissionais possam acompanhar a dinâmica que envolve o setor e suas constantes transformações.

Destaca-se entre os principais objetivos da educação profissional, tratados nas políticas públicas de educação, a geração de emprego e renda, como um fator de inclusão social. Para averiguar o cumprimento dessa premissa este estudo buscou evidenciar se os cursos de qualificação ofertado pelo PRONATEC Turismo se pautaram nas ACT's e se consequentemente possibilitaram a estruturação de uma carreira no setor, deste modo, procurou-se verificar a aderência dos cursos, empreendidos pelo MTur por meio do PRONATEC Turismo, as normas internacionais e nacionais que regem o turismo, tais como International Standard Industrial Classification (ISIC-OMT) ${ }^{50}$, Lei Geral Turismo (no11.771/2008) $)^{51}$, e Atividades Características do Turismo (ACT's-IPEA) ${ }^{52}$, bem como a Classificação Nacional de Atividades Econômicas (CNAE-IBGE) a Classificação Brasileira de Ocupações (CBO-MTE) e a Associação Brasileira de Normas Técnicas (ABNTNBR-Turismo $)^{53}$, e, que sistematizam o mercado de trabalho do setor.

\footnotetext{
${ }^{50}$ A Organização Mundial do Turismo (OMT) estabeleceu uma metodologia para implementação de Conta Satélite do Turismo (CST), na qual recomenda a adoção, como mínimo (primeiro nível), das chamadas Atividades Características do Turismo, onde se incluem, basicamente, unidades prestadoras de serviços, tais como: Hotéis e similares, Restaurantes, diversas modalidades do Transporte, Aluguel de meios de transporte, Lazer, Esporte e Cultura e Agências de Viagens.

${ }^{51}$ A Lei no 11.771/2008 em seu Art. 21 considera prestadores de serviços turísticos as sociedades empresárias, sociedades simples, os empresários individuais e os serviços sociais autônomos que prestem serviços turísticos remunerados e que exerçam as seguintes atividades econômicas relacionadas à cadeia produtiva do turismo: I - meios de hospedagem; II - agências de turismo; III transportadoras turísticas; IV - organizadoras de eventos; V - parques temáticos; e VI acampamentos turísticos.

${ }^{52}$ Com referência na metodologia da OMT o IPEA em parceria com o MTur elaborou estudos sobre o mercado de trabalho do setor de turismo com a definição das Atividades Características do Turismo (ACT'S).

${ }^{53}$ Comitê Brasileiro de Turismo (ABNT/CB-54), instituído em 2002, responde pela elaboração das normas do setor, as quais se tornaram forte referencial porque tiveram a participação da sociedade em todas as etapas de elaboração. Destacou, entretanto, que a organização precisa acompanhar as atividades dos organismos internacionais, como é o caso da ISO e seu Comitê Técnico 228, de Turismo e Serviços Relacionados, para que o setor se mantenha atualizado com as melhores práticas e conquiste competitividade e excelência.
} 
Para subsidiar esta análise foi construído o Apêndice $D$, elaborado pela autora, que auxiliou quanto à observação desses cursos e sua correlação com tais normas, focando principalmente nas Atividades Caraterísticas do Turismo que são consideradas estruturantes pela OMT e seguidas pelo Ministério do Turismo como forma de identificar as atividades inerentes ao setor. Buscou-se, ainda, fazer um link com as ocupações do turismo e hospitalidade, reconhecidas pelo MTE que possuem condições de se efetivarem enquanto carreiras e com as NBR do Turismo que apresentam requisitos mínimos (competências, habilidades e atitudes) esperados dos profissionais do setor, conforme apontamentos:

$\checkmark$ os cursos da área de alimentação (garçom, confeiteiro, cozinheiro entre outros), estão correlacionados, com as ACT's, com alguma ocupação do turismo e hospitalidade e com as NBR's, que apontam competências, habilidades e atitudes esperadas dos profissionais; observa-se porém que o curso de atendente de nutrição não possui ocupação definida pelo MTE;

$\checkmark$ os cursos ofertados na área de alojamento, como: recepcionista em meios de hospedagens, camareira, mensageiro, também trazem uma estreita relação com essas três dimensões;

$\checkmark$ os cursos da área de eventos (cerimonialista e mestre de cerimônias, organizador de ventos e recepcionista de eventos) e os de agenciamento de viagens são correlatos às ocupações, no entanto não existem ACT especifica e tampouco NBR's que tratem deste assunto;

$\checkmark$ para a área de transportes não foram ofertados cursos, apesar de ser uma área com muita representatividade nas ACT's e nas ocupações correlatas ao turismo; não se apresentam NBR's que tratem deste tema;

$\checkmark$ os cursos ofertados na área de cultura e lazer, tais como: operador de câmara, agente cultural, recreador e condutor de turismo de aventura guardaram consonância com as ocupações, quanto ao curso de agente de informações turísticas não se identificou uma ocupação correlata;

$\checkmark$ os cursos de idiomas, foram os que tiveram maior oferta e demanda, no entanto não estão correlacionados com ocupações do setor.

Com base nessas interpretações foi possível tecer algumas considerações sobre a práxis encontrada na oferta de cursos pelo PRONATEC Turismo e se estas 
foram possibilitadoras de construção de carreiras no setor. Permitindo observar que os cursos ofertados nas áreas de alojamento, alimentação, eventos e cultura e lazer, ocorreram apenas no âmbito das ocupações operacionais, enquanto que as ocupações de direção e gerência não foram contempladas por nenhum desses cursos. Mostra-se assim mais uma vez a fragmentação da política pública de qualificação, ao não articular a oferta de cursos técnicos e tecnológicos na área de turismo e hospitalidade, cursos que poderiam atender de forma mais efetiva a premissa para a construção de carreiras no setor. Cominando com a teoria levantada neste trabalho a qual aponta que a educação profissional foi concebida distinta da educação regular, para atender a camadas menos favorecidas da sociedade, atribuindo-lhes apenas conhecimento técnico e competências operacionais, sem preocupação com a formação integral dos trabalhadores que possa Ihes atribuir autonomia e emancipação.

Corrobora com esse entendimento o que aponta, o próprio MTur (2013) no Relatório de Índice de Competitividade do Turismo Nacional:

\footnotetext{
Uma defasagem na oferta de pessoal local capacitado para atuar na gerência de empreendimentos turísticos, em especial nos meios de hospedagem, sinalizados por diversos empresários entrevistados na maior parte dos destinos. (BRASIL 2013bb).
}

Outro ponto identificado diz respeito a cursos da área de lazer, tais como: condutor de turismo ambiental local, monitor ambiental, condutor de turismo de pesca, que não foram ofertados, sendo que esses dois primeiros por falta de aderência a ocupações que ainda não foram identificadas pelo MTE, o que mostra um descompasso da política de trabalho e emprego com a realidade da dinâmica do turismo, que envolve uma demanda por atividades diferenciadas para atender a diversidade do setor, o que poderia ter se constituído em oportunidade para inserir a comunidade local no mundo de trabalho.

Outro descompasso em relação à ocupação ocorreu com a oferta do curso agente de informações turísticas, que conforme pontuado acima consiste de uma das atividades necessária ao turismo, que são executadas nos centros de informações turísticas, portanto constitui-se de uma ocupação informal do turismo, 
enquanto não for reconhecida pelo MTE, fato que prejudica a efetivação de uma carreira.

Os cursos de atendente de nutrição, agente de limpeza urbana, instalador e reparador de rede de TV a cabo e via satélite e instalador e reparador de linhas e sistemas de telefonia destoam das ACT's, pois não são ocupações ligadas diretamente ao setor.

Verifica-se ainda que a concentração da oferta ocorreu por meio dos cursos de idiomas, entretanto, essas ações deveriam ser complementares e transversais as ocupações do setor, apesar de possuir uma enorme demanda, o curso por si só não pode potencializar a estruturação de uma carreira profissional em turismo e hospitalidade. Assim ele deveria ser disponibilizado como uma ação de qualificação continuada, ou seja, para egressos de outros cursos.

Buscando analisar para além das aparências interpretadas por meio desses documentos, recorreu-se a análise de conteúdo para examinar como isso ocorreu na práxis estabelecidas pelos egressos dos cursos, conforme relatos abaixo:

O curso permitiu a progressão na carreira: "acredita que sim. Apesar de estar desempregada, sente-se preparada para ingressar no mercado de trabalho" (egresso n); "galga crescimento, mas condicionado a outros cursos complementares de capacitação" (egresso o); Constata-se nesses discursos que a primeira egressa do curso de libras considera possível construir/progredir em uma carreira no setor, entretanto permanece desempregada. Este fato corrobora com a análise documental que apontou que os cursos de idiomas são complementares a uma ocupação, no entanto, ao ser oferecido sem atentar-se a questão da empregabilidade e construção de carreira se constata a fragmentação deste processo que gera uma práxis com resultados parciais e pouco efetivos. Enquanto que a segunda egressa percebe que para atingir essa premissa ela precisa de outros cursos, ou seja, educação continuada.

A educação continuada está expressa na LDB como uma prioridade para a educação profissional que deverá ser desenvolvida em articulação com o ensino regular ou por diferentes estratégias de educação, em instituições especializadas ou no ambiente de trabalho. O conhecimento adquirido por meio dessa modalidade, inclusive os adquiridos no local de trabalho, poderão ser objeto de avaliação, 
reconhecimento e certificação para prosseguimento ou conclusão de estudos. Esta perspectiva de uma educação continuada ao longo da vida deve ser efetivada. Somente desse modo, será possível vislumbrar uma maior profissionalização do trabalho no País.

Constatou-se ainda no discurso da professora (I) outra fragmentação desse processo, uma vez que existe na instituição de ensino um setor responsável em apoiar a inserção do egresso no mercado de trabalho, mas isto não se efetivou: "a Unidade Rede de carreiras é um departamento do SENAC que procura fazer a ponte do egresso com o mercado [...], contudo não temos informações, ainda, acerca da condição atual do egresso no mercado de trabalho".

Tendo em vista que a construção/progressão de carreira depende do acesso ao mercado de trabalho, pelos dados da pesquisa de campo infere-se que isso pouco aconteceu, ao considerarmos que em torno de $10 \%$ (dez por cento) dos egressos conseguiram empregos no setor. Diante disto infere-se que a empregabilidade no período dos megaeventos esportivos e a inclusão social de jovens e adultos, egressos do PRONATEC Turismo, nas cidades sedes ficou comprometida, o que fica perceptível na fala dos egressos e professores: "[...]mas em compensação o mercado não absorveu muitos desses alunos por considerar que estes não concluíam, devidamente, qualificados"; "as pessoas prestam serviço, grande maioria não tinha um vínculo formal de emprego" (gestor c); "poucos egressos empregados. O profissional do Turismo é mal remunerado e isso dificulta muito" (gestor b); "positivo: crescimento pessoal, inserção no mercado de trabalho"; “ajudei umas 5 pessoas a ingressarem no mercado de trabalho do setor"(egresso h).

Nota-se que, na maioria dos casos, houve correlação dos cursos, no período de 2012-2015, às ACT's, entretanto a premissa que apontou como consequência a estruturação de carreiras não foi viabilizada adequadamente, porque não bastam que os cursos estejam de acordo com as ACT's (que se apresentam desatualizadas) para que se efetivem carreiras no setor. Em primeiro lugar é necessário estruturar esse setor, a começar por planos de carreiras e ascensão profissional, programas de educação continuada articulada ao ensino básico e, também superior, e, planos de inserção profissional no mundo do trabalho de turismo e hospitalidade. 
Em relação à empregabilidade no período dos megaeventos esportivos e a inclusão social de jovens e adultos, egressos do PRONATEC Turismo, nas cidades sedes pouco se percebeu a medida que um baixo contingente de egressos conseguiram se inserir no mercado de trabalho, e, a prerrogativa de inclusão social não está garantida apenas pela inserção profissional.

Por outro lado, as contradições encontradas na análise de conteúdo são percebíveis, assim se faz necessário destacar o principal problema enfrentado na construção da pesquisa que impedem uma avaliação real de todo o processo de execução do PRONATEC Turismo, a falta de um processo efetivo de acompanhamento e avaliação da política pública por meio do MTur, dos Órgãos de turismo e das instituições de ensino, tendo em vista que isto afetou diretamente a pesquisa pela dificuldade de localizar egressos dos cursos, o que se evidenciou nas pesquisas regionais realizadas em São Paulo, Fortaleza e Recife conforme (APÊNDICE A).

Outros fatores que ocasionaram entraves para a obtenção de dados mais completos sobre a implantação/execução da política pública de qualificação profissional, PRONATEC Turismo, foram as dificuldades para se ter acesso aos gestores estaduais, municipais e, das instituições de ensino, sobretudo do sistema S. A falta de interesse em participar da pesquisa ou indisponibilidade de agenda, os poucos posicionamentos propositivos de colaboração, por parte das instituições e gestores foram fatores determinantes para o processo investigativo e conclusivos quanto aos resultados, de maneira que mesmo quando se conseguia contato os supostos responsáveis não sabiam informar acerca dos pontos levantados. (Pesquisa avaliativa dos arranjos territoriais possibilitadores da qualificação em turismo, 2016).

Estes entraves trazem coerência a alguns elementos encontrados na oferta dos cursos, como, o descompromisso, a falta de empenho e a não valorização do programa de qualificação apresentados por alguns gestores e egressos. Todavia há casos de boas práticas, que serão tratados no próximo subcapítulo, nos quais os cursos foram efetivados para além do ensino puramente técnico e operacional, nos quais os professores se empenharam para tratar conteúdos paralelos que pudessem proporcionar alguma forma de autonomia e desenvolvimento humano. Entretanto, 
tratando-se de uma política pública, é inconcebível que essas mudanças se operacionalizem apenas pela vontade e iniciativa pontual de algumas pessoas.

A estrutura organizacional proposta pelo PRONATEC, a saber: a) o auxílio financeiro ao aluno (bolsa); b) a gratuidade dos cursos; c) o oferecimento de lanche aos alunos nos intervalos das aulas, contribuindo com aqueles participantes que, após muitas horas de trabalho, chegavam ao curso visivelmente cansados e com fome; d) a disponibilização de material didático, dado a riqueza de detalhes e a qualidade de seu conteúdo que, em alguns cursos contribuía notoriamente; e) a viabilização de uniformes, como camisetas do projeto/programa, que estimularam os alunos a se reconhecerem como parte de uma ação coletiva de grande importância no município; f) a forma de acolhimento dos alunos e professores por meio da disponibilização de espaços físicos adequados para a realização das atividades pedagógicas; g) equipamentos em bom estado para suporte as aulas, escolas bem estruturadas, salas com cadeiras confortáveis, contribuíram para que o aluno não perdesse o interesse pelo aprendizado. Estes elementos foram identificados pelos entrevistados, em algumas regiões do país, como ações de efetivação e permanência dos alunos. (MOESCH (org) 2016).

A realidade da baixa escolaridade dos alunos do PRONATEC Turismo ficou evidenciada em muitas localidades o que exigiu dos professores um esforço maior para que fossem atendidas e superadas as dificuldades no processo de aprendizagem. Foi fundamental para a manutenção destes alunos o interesse dos professores em adaptar os conteúdos à realidade e necessidades apresentadas por estas experiências de ensino-aprendizagem.

Verificou-se que nas realidades territoriais onde houve articulação entre os gestores públicos, as instituições ofertantes e a sociedade civil organizada, o diagnóstico das necessidades de qualificação foram apropriados, atendendo às expectativas, bem como o número de evasões foi menor.

Nota-se que a política de qualificação em turismo e hospitalidade concebida e implementada pelo MTur apostou na qualificação profissional ao estruturar o PRONATEC Turismo, cuja principal finalidade foi a melhoria da qualidade dos serviços ofertados aos turistas nas cidades sedes dos megaeventos. 
Seguindo esse objetivo o Plano Nacional de Turismo (2013-2016) foi idealizado com foco em potencializar o turismo diante das oportunidades trazidas pela Copa do Mundo FIFA 2014 e pelas Olimpíadas Rio 2016, por meio do aumento da demanda de turistas e da divulgação das potencialidades do turismo brasileiro no mercado internacional.

"O desempenho do Brasil como anfitrião desses encontros será decisivo para transformar o país no terceiro maior Produto Interno Bruto turístico do mundo até 2022". (PNT, 2013).

O objetivo e a estratégia delineados no Plano são ambiciosos: "sair da sexta para a terceira economia turística do planeta. Isto tudo por meio de um crescimento sustentado e sustentável, redução de desigualdades regionais, inclusão social e geração de emprego e renda". (BRASIL, 2013z).

Neste contexto a qualificação foi destinada a alavancar a competitividade dos destinos turísticos, gerar emprego e renda e possibilitar a inclusão social dos trabalhadores no setor, todavia os projetos primaram pelo desenvolvimento de competências e habilidades para atender as demandas do mercado e não as necessidades dos trabalhadores, como ampliação de sua escolaridade.

As ações de formação foram pontuais e descontínuas, os cursos ofertados atenderam a nichos específicos do mercado, e muitos ofertados de forma precária, com foco no aprendizado bancário ${ }^{54}$, com demanda pelo treinamento operacional sem a devida atenção ao ensino problematizador e emancipador.

Essa ideia está presente no Relatório da UNESCO (1998) o qual aponta que a procura da educação para fins econômicos não parou de crescer em grande parte dos países e as comparações internacionais destacam a importância do capital humano $^{55}$ para este fim, e, portanto, do investimento educativo para a produtividade.

Esta concepção, adotada pelo PRONATEC Turismo trata o trabalhador como capital da produção e do trabalho, apresentando-se contraditório ao pressuposto de desenvolvimento humano e inclusão social exposto pelo documento do PNUD

\footnotetext{
${ }^{54}$ De acordo com Freire, 1974 a aprendizagem bancária consiste na imposição do conhecimento realizada pelo professor sobre o aluno, na medida em que o professor já os possui e dispõe destes, sendo assim possível sua ação de depósito deste conhecimento aos alunos.

${ }^{55}$ Grifo nosso
} 
(2015, p.51) que entende "O desenvolvimento humano é um processo de ampliação do leque de escolhas das pessoas, pelo que está intimamente relacionado com o trabalho que estabelece uma relação positiva recíproca". Quando uma epistemologia está presente numa ação política ela evidencia também a ideologia presente nessa ação, assim, o discurso do governo quanto à qualificação profissional em turismo é contraditório, senão equivocado, para os fins desejados de inclusão social, pois vão de encontro a concepção de desenvolvimento humano do próprio organismo fomentador de muitas dessas ações do Ministério do Turismo, o PNUD.

\begin{abstract}
A noção de desenvolvimento humano precisa ser contextualizada para que se torne uma base analítica mais relevante para permitir fazer face aos desafios emergentes num mundo em mudança. As questões relacionadas com as capacidades e as escolhas individuais e coletivas e as prováveis compensações recíprocas entre elas em diversas situações, as possíveis hierarquias entre tais escolhas, as escolhas e capacidades (que refletem a noção de sustentabilidade) inter-geracionais (para as gerações do presente, mas também do futuro) e o desenvolvimento humano em situações de choque e vulnerabilidade são elementos que terão de ser revisitados a fim de tornar o quadro atual mais robusto e pertinente para o futuro. (PNUD, 2015, p. 79).
\end{abstract}

Consequentemente a adoção dessas ideologias conservadoras nortearam as práticas da política pública de qualificação profissional, pelo PRONATEC Turismo, nas quais os sujeitos alvos das ações de qualificação foram considerados "capital", no sentido de insumo, de um sistema fechado, de input /output, nesse processo que visa o crescimento do turismo.

O planejamento estava focado nas metas quantitativas em detrimento das qualitativas. A questão primordial era qualificar trabalhadores para o setor, de modo a suprir a necessidade de mão de obra treinada e apta a prestar serviços com qualidade e padrão internacional, o que poderia contribuir para a principal meta: aumentar a competitividade do turismo no mercado internacional, por conta da visibilidade advinda com a Copa do Mundo de Futebol FIFA 2014.

O objetivo das ações do MTur é qualificar profissionais da área de Turismo e Hospitalidade que atuam nos diversos segmentos do setor, oferecer um leque de novas oportunidades para o setor e promover a inclusão social pelo turismo, por meio de ferramentas que ampliem o conhecimento operacional e contribua para o aumento da qualidade dos serviços ofertados ao turista dos grandes eventos internacionais a serem realizado no Brasil de 2012 a 2016. (Brasil, 2011aa). 
Essa visão reducionista centralizou nos trabalhadores uma responsabilidade descabida, ser o "protagonista" nos bastidores, para atingir uma meta audaciosa que depende de uma concentração de esforços para ser atingida, uma visão sistêmica do Turismo.

Os trabalhadores são parte fundamental desse processo, no entanto apenas o treinamento técnico e operacional das ocupações não consegue dar conta desse encargo. Somente por um processo de educação continuada pode-se criar condições para emancipação profissional e cidadã desses profissionais que assim poderão contribuir para o efetivo desenvolvimento do turismo.

"Em pleno limiar da sociedade do conhecimento, o Brasil precisa abandonar a concepção conservadora e ultrapassada do trabalho como obrigação pela sobrevivência para reconstituir uma nova transição do sistema escolar para o mundo do trabalho". (Pochmann, 2004 p. 397). Dessa forma a educação continuada ao longo da vida, se faz urgente visando conciliar trabalho e formação profissional.

Ao instituir o PRONATEC Copa, o MTur centralizou o processo de planejamento e implementação do Programa, trazendo para si a responsabilidade da execução diretamente das ações, sem a participação dos Estados, DF e Munícipios, o que se mostrou logo de início inviável, devido a enxuta estrutura do Departamento de Qualificação e da falta de pessoal com expertise na área de educação/formação profissional, bem como a baixa capilaridade que o Ministério enfrentava frente ao setor privado que poderia ter se constituído de um importante parceiro para a efetivação do Programa.

No segundo semestre de 2012 houve uma reformulação no PRONATEC Copa, (BRASIL, 2015t) que passou a ser intitulado PRONATEC Turismo, nessa nova proposta os órgãos estaduais, distrital e municipais de turismo passaram a compor o processo de execução do Programa, tendo como atribuições o levantamento das demandas por qualificações junto ao trade, articulação com o sistema de ensino para a oferta de turmas, efetivação de pré-matrículas e acompanhamento das turmas. Este processo foi monitorado e acompanhado de perto pelo MTur, no entanto, questões relativas oferta $x$ demanda, a formação adequada dos profissionais do setor e dos futuros egressos não puderam ser 
resolvidas a contento, apenas paulatinamente, pois havia uma engessamento do PRONATEC (MEC) e do próprio MTur, conforme destacados abaixo, que não possibilitava os ajustes necessários para que o Programa realmente atendesse ao setor de turismo e hospitalidade e suas especificidades.

\begin{abstract}
Foram apresentadas dificuldades com relação ao Sistema Nacional de Informações da Educação Profissional e Tecnológica (SISTEC) e aos prazos, relatou-se a complexidade de se trabalhar com demandas de empresa e de sensibilização do empresário e, uma vez, captado este público, torna-se prejudicial a espera dos prazos de controle (pactuação, repactuação e homologação) estabelecidos pelo Ministério da Eduçção (MEC) para o fechamento da turma, os problemas elencados foram: evasão de alunos e descredibilidade por parte do empresário do Programa; foi sugerido pela represente do Estado a possibilidade do ofertante trabalhar com mais autonomia neste sentido para que se possa atender a demanda de forma mais rápida. Houve críticas em relação aos prazos do Programa em geral, enfatizou-se o longo período de repactuação e lamentaram a perda do tempo que tiveram para abertura de turma em ano decisivo, o da Copa do Mundo no Brasil. (BRASIL, 2014u p. 9).
\end{abstract}

O compilado apresentado a seguir resulta dos apontamentos do próprio MTur verificados na minuta do documento Relatório de Avaliação de Resultados: PRONATEC Turismo (Período: 2012 a 2014), (BRASIL, 2015dd).

O documento aponta as limitações de responsabilidade do MEC e instituições de ensino e as limitações por parte do MTur.

- Criação e publicação de turmas específicas para o MTur, de modo a atender adequadamente a demanda identificada;

- Disponibilidade de turmas de idiomas exclusivas para o turismo;

- Demora na resolução de problemas operacionais do SISTEC ${ }^{56}$;

- Prejuízos aos candidatos que não conseguem se inscrever ou confirmar matrícula em função de problemas relacionados ao SISTEC;

- Demora no início de turmas em função do processo de pactuação ${ }^{57}$ ocasionando desistência por parte dos alunos;

- Falta de docentes para atender cursos pactuados;

\footnotetext{
${ }^{56}$ Programa remoto onde são feitas todos os trâmites (pactuação de vagas, oferta de turmas, matrículas e acompanhamento dos alunos de reponsabilidade do MEC).

${ }^{57}$ Processo que ocorre no SISTEC/MEC no qual as instituições de ensino disponibilizam vagas para os cursos vinculados ao PRONATEC.
} 
- Falta de transparência e de disponibilização de informações pelo ofertante (planos de cursos e calendários de turmas);

- Ofertas desconexas as demandas;

- Alto índice de evasão;

- Precarização do trabalho dos profissionais da educação;

- Discrepância entre idade e nível dos estudantes;

- Limitações no funcionamento do SISTEC;

- As instituições de ensino possuem pouco tempo de preparação para iniciar os cursos;

- A escolaridade exigida para realização dos cursos não é suficiente para concretização de um curso de formação inicial continuada em curto prazo;

Por parte do MTur:

- Equipe técnica reduzida para atender as demandas do Programa;

- Ausência de repasse de recursos para os órgãos de turismo a fim de subsidiar as ações do programa;

- Falta de material de divulgação;

- Carência de Informações da oferta e demanda turística (inventários e pesquisas);

Esses apontamentos apresentam a dicotomia que envolveu o processo de implementação do Programa, na medida em que as suas metas previam a qualificação de um grande contingente de pessoas, em um curto período, o que demandaria uma operacionalização mais efetiva em todos os processos de execução e uma estreita articulação entre os Ministérios (MTur-MEC-MTE) e as instituições de ensino para a rápida resolução dos problemas detectados, o que na prática não ocorreu porque esbarrava na subjetividade revestida de burocracia, inerente ao setor público, o que dificultava, ainda mais, mitigar esses entraves.

A política de qualificação previa resultados incisivos para o setor de turismo, entretanto, sem a estruturação adequada para a execução, o acompanhamento e a avaliação, isso ficou comprometido. De acordo com a dialética o exercício da 
criticidade deve ser permanente, considerando que a coerência da crítica está na autocrítica, pois não é possível criticar sem apresentar-se como criticável. A crítica se completa numa contraproposta (soluções) não sendo sustentável a mera crítica, destrutiva, sem compromisso com construção concreta (resolver os entraves) para prosseguir. (DEMO, 1995).

Essas limitações implicaram as inciativas do MTur em prosseguir com 0 processo para elaboração de insumos para institucionalização de uma política nacional de formação em turismo e hospitalidade, visando promover uma mudança estrutural nas ações de qualificação, em busca de resultados efetivos para a qualificação e o consequente desenvolvimento do setor. O processo ocorreu em paralelo à execução do PRONATEC Turismo ${ }^{58}$.

Objetivando a crítica, como forma dialética de avançar, em 2015 foram estabelecidas as Diretrizes Nacionais de Qualificação em Turismo que identificaram a necessidade de se constituir uma política nacional de formação para o setor, que possibilite o empoderamento dos trabalhadores e minimize as lacunas existentes nas relações de trabalho do setor de turismo e hospitalidade. (BRASIL, 2015a).

Em continuidade, a Pesquisa Avaliativa dos arranjos territoriais possibilitadores da qualificação em turismo (2016), elaborada pelo CTE/UnB em parcerias com Instituições de Ensino Superior representativas das 5 (cinco) regiões do Brasil $^{59}$, possibilitou avaliar as ações empreendidas pelo MTur, como forma de identificar os entraves e as boas práticas, de modo a mitigá-los e/ou aperfeiçoar, visando compor uma proposta de uma política de estado que perpasse as várias trocas de governo e se constitua em um documento de referência para a formação profissional em turismo e hospitalidade. (MOESCH, 2016).

\footnotetext{
58 Desde 2014 a UnB vem atuando em parceria com o MTur na produção de insumos para elaboração de uma política nacional de formação em turismo e hospitalidade com base em uma pesquisa avaliativa sobre os Arranjos Territoriais Possibilitadores da Qualificação em Turismo (2016), que resultou em um documento de referência para a implantação da Política Nacional de Formação Profissional em Turismo e Hospitalidade (2016).

59 Compuseram a rede 44 pesquisadores pertencentes às instituições federais: Universidades Federais do Rio Grande do Norte, Pará, Fluminense, Paraná, Ouro Preto, Rio Grande do Sul, somada à Universidade de São Paulo e ao Instituto Federal de Educação Ciência e Tecnologia da Bahia. Rede de as universidades federais e institutos federais que possuem formação e experiência no campo do turismo e hospitalidade.
} 
A pesquisa identificou que, frequentemente, as ações de qualificação foram apenas compensatórias diante das desigualdades educacionais e sociais dos sujeitos participantes dos cursos de qualificação. Observando-se a presença de qualidade formal dos cursos, ou seja, houve preocupação na montagem dos instrumentos e métodos, contudo nenhuma atenção foi dada à qualidade política que se refere às finalidades e aos conteúdos. (MOESCH, 2016).

O estudo promoveu uma extensa avaliação a partir dos atores sociais envolvidos nessas ações de qualificação, objetivando enxergar para além do que é perceptível pela sociedade, buscando pela interpretação dialética, a observação da totalidade/fragmentação que o envolveu. Possibilitou, ainda, a (des)construção dessa política que resultou na elaboração do Documento de Referência para a Formulação da Política Nacional de Formação Profissional em Turismo e Hospitalidade (PNQT). Documento que apresenta novas preposições para a política pública de formação profissional, cujo objetivo é avançar, despontando como uma política de estado. (MOESCH, 2016).

Tendo como referência à dinâmica que evolveu o processo de implementação das ações de qualificação, o documento transmuta os achados em campo (teoria/prática) em oportunidades para transformar essa política em uma ação efetiva que coadune com o desenvolvimento humanizador pelo turismo, perpassando por um processo de educação integral dos sujeitos.

Com base nas observações da realidade encontrada nos territórios onde ocorreram as qualificações pelo PRONATEC Turismo, identificaram-se os principais obstáculos inerentes à implementação do Programa destacando: a falta de definição de critérios para avaliação pedagógica em relação às habilidades e competências das ocupações do turismo e hospitalidade; a carência de um processo de gestão da qualidade e da eficácia dos cursos de formação e sua relação com a competitividade dos destinos turísticos: "acredito que um curso de qualificação em turismo deve abranger, de forma global e interdisciplinar, aspectos econômicos, políticos e sociais da atividade turística na localidade, trazendo exemplos práticos e reais" (gestor a).

Apontou que a oferta dos cursos não atendeu as expectativas dos trabalhadores pelo seu conteúdo/forma/concepção (explicito nas falas de alguns entrevistados) "Esse período de 3 meses não vai transformar uma pessoa leiga em 
um organizador de eventos", "Parcialmente, como a área é muito ampla, ficaram muitos vazios de conteúdos a serem ministrados", "Os cursos não abrangem a todas as necessidades relacionadas ao tema, ou ao cargo".

Fica explícito nessas evidências que não se conseguiu atingir um processo de educação virtuosa, que proporcionasse a integração dos conteúdos técnicos, operacionais, culturais e sociais, tão necessários ao desenvolvimento endógeno do setor. A noção da autonomia humana é um processo complexo, como todos os demais que envolvem o sujeito, ela depende de condições culturais e sociais para existir. Essa autonomia se alimenta da dependência e vice versa. Depende de uma educação, de uma linguagem, de uma cultura, de uma sociedade, para a construção do refletir de maneira autônoma. (MORIN, 2005).

Ademais o documento sinaliza como dificuldades a serem superadas: o baixo nível de escolaridade de muitos profissionais do setor, bem como de uma gama expressiva da sociedade que se encontra em situação de desemprego e que são públicos alvos do Programa; a dificuldade de conciliar o trabalho com a formação profissional e os baixos salários comumente praticados acaba conduzindo esses trabalhadores para as periferias o que denota dificuldades em se deslocar aos cursos, aliados a falta de estímulo para que os profissionais voltem aos estudos ocasionam muitas evasões e barreiras para a elevação da escolaridade.

Os discursos evidenciam essas percepções: "muita evasão aconteceu pela falta de interesse, onde muitos estavam interessados pelo dinheiro onde de 100 aulas, o aluno foi em 20" (professor a); "evasão devido à falta de repasso das bolsas." (professor c).

Complementam essas percepções a ênfase em disponibilizar cursos que se articulem com as demandas e necessidades turísticas locais (demandas sociais), com aulas que permitam integrar os conteúdos técnicos aos saberes e experiência dos sujeitos. Pressupõe formatar conteúdos que trabalhem na perspectiva de um processo de formação da cidadania e emancipação dos trabalhadores do setor; integrar programas de qualificação aos demais programas de educação profissional em cada território como os Institutos Federais, o SENAC e o sistema de ensino formal existentes na área de turismo e hospitalidade. 
Essa integração possibilitaria uma maior oportunidade de inclusão social, pelo acesso ao emprego digno, ao trabalho autônomo ou heterônomo, pois ao se potencializar o desenvolvimento humano pela educação e pelo trabalho se estimula também a inclusão social, pessoas preparadas e inseridas em um mercado de trabalho digno têm condições de se projetarem socialmente e de acompanharem as crescentes mudanças e transições do mundo do trabalho e da sociedade em geral. Como consequência utilizam o seu potencial criativo, crítico e participativo, operacionalizando a cidadania nos âmbitos civil, político e social.

[ ] a cada um destes elementos corresponde um conjunto de direitos. A saber, a cidadania civil é formada pelos direitos necessários à liberdade individual; a cidadania política pelos direitos de participação no exercício do poder político; e a cidadania social pelo conjunto de direitos, que inclui segurança e bem-estar econômico, o direito de compartilhar a riqueza socialmente produzida e o de viver uma vida civilizada, segundo os padrões sociais vigentes. (SILVA, 2000, p.127)

Para implementação dessa nova política incumbe à definição clara e objetiva dos papéis dos entes federativos (união, estado, DF e município), no processo de planejamento, gestão, financiamento, acompanhamento, monitoramento e avaliação, primordial para a ocorrência de uma política pública que atenda as dinâmicas do turismo e hospitalidade.

Parcerias que permitam elaborar proposta sistêmica com objetivos nacionais e propostas territorializadas que atendam as especificidades dos territórios. Foi sugerido o aproveitamento dos Observatórios de Turismo, como ferramenta para o acompanhamento, monitoramento, avaliação da implementação das ações de qualificação, por meio da sistematização de demandas territoriais, planos territoriais de formação profissional, acompanhamento de egressos, articulação com o mercado de trabalho para inserção profissional, entre outras ações necessárias para a efetividade do Programa, visto que essas ações possibilitarão que a região tenha uma memória política registrada para além das mudanças governamentais;

Howlett e outros (2013) ${ }^{60}$ apud Heidemann; Salm (2014) pontuam que o processo para de decisões politicas se desdobra em cinco estágios: o estabelecimento ou montagem da agenda (de acordo com os problemas

\footnotetext{
60 Ibid p. 51.
} 
demandados); a formulação de política (o modo como as propostas são formuladas); a tomada de decisão política (processo pelo qual os governos adotam um curso de ação ou inação); a implementação da política (como os governos dão efetividade à política) e a avaliação da política (como os atores estatais e societário monitoram os resultados da política). Processo este que pode resultar na requalificação dos problemas e das soluções.

Incumbe também ampliar as parcerias locais voltadas à inserção de egressos no mercado formal e a proposição de ações de apoio do empresariado do setor na viabilização de oportunidades de estágio e de emprego, como forma de construção de carreiras, diminuição da informalidade no setor e da rotatividade. Essas propostas podem superar um equívoco do Programa ao considerar o número de matrículas como indicador de efetividade, sendo que a relação de efetividade/eficiência deveria estar atrelada à inclusão social dos trabalhadores, à elevação da escolaridade e à continuidade do processo de ensino aprendizagem ao longo da vida.

Percepção presente na fala de alguns entrevistados: "a preocupação era somente com números" (gestor a); "o curso PRONATEC é muito equivocado para o perfil do aluno, não existe um encaminhamento e sem muito objetivo é somente números para o governo" (gestor d).

Em relação à oferta de cursos que coadunem com as propostas de uma educação para o século XXI o documento propõe a criação de uma unidade de processos para concepção dos cursos e estruturação do programa, envolvendo a participação dos professores/instrutores do território; ajustes em cargas horárias para que haja uma formação mais completa, vislumbrando atividades práticas e conteúdos que permitam a formação integral dos sujeitos e conteúdos conectados ao contexto global e local; e, atuar com uma pedagogia problematizadora que vise o desenvolvimento integral dos trabalhadores do setor e uma maior participação destes em prol do turismo.

Em que pese à apresentação dos limites do PRONATEC Turismo enquanto política para inclusão social se apresentam, ainda, fatores possibilitadores dessa premissa, tais como: estrutura física das instituições de ensino de ótima qualidade; corpo docente e técnico qualificado; bolsa formação bastante ampla (caderno, 
uniforme, auxílios); oferecimento de cursos de idiomas; oportunizar a continuidade aos estudos e a geração de emprego e renda; estimular e apoiar o empreendedorismo e o cooperativismo; e, a diversificação de segmentos atendidos.

Essas propostas foram subsidiadas pelos achados de campos que promoveram uma crítica ao processo de execução do PRONATEC Turismo, possibilitando ir para além da alienação rumo à autonomia.

Esses achados permitiram, ainda, inferir que os cursos ofertados pelo Programa, em sua maioria, seguiram o padrão SENAC ("Os cursos ofertados nesses programas eram cursos do catálogo do SENAC e que seguem as premissas, orientações e catálogo do MEC, bem como os critérios pedagógicos da instituição" gestor a), ou seja, sobre medida para preparar profissionais com ênfase em competências técnicas e operacionais, inclusive no que cabe aos conteúdos e a carga horária que foram estipulados independente da especificidade dos públicos: profissionais atuantes ou pessoas desempregadas sem nenhuma experiência no setor. Não houve ajustes oficiais nos conteúdos para atender públicos tão distintos, apenas tentativas junto ao MEC em termos de necessidades de cursos, número de vagas disponibilizadas e algumas discrepâncias, como por exemplo, cursos de condutor ambiental, condutor cultural, monitor ambiental e monitor cultural, disponíveis no catálogo de cursos FIC, mas que não correspondiam a legislação correlata em relação às atribuições do guia e as ocupações do MTE.

Neste ponto apresenta-se mais uma vez a discrepância entre teoria e a prática na elaboração e implementação das políticas públicas, uma vez que existe no mundo do trabalho do setor de turismo e hospitalidade uma demanda por diferentes perfis de trabalhadores, como, por exemplo, os condutores de turismo local (comunidades indígenas, quilombolas), ocupações que ainda não são reconhecidas pelo MTE. Coaduna com a percepção de um gestor de que "a política foi positiva, mas deficiente quanto à operacionalização" (gestor b).

Ademais essas discrepâncias ficam evidenciadas nas críticas dos sujeitos: "parcialmente, como a área é muito ampla, ficaram muitos vazios de conteúdos a serem ministrados" (professor g); "durante o PRONATEC eu peguei os conteúdos já prontos" (professor j); "a duração do curso foi insuficiente para atender as 
necessidades do educando, precisaria ter uma ambientação, nivelamento para depois entrar nos conteúdos básicos e específicos" (professor i).

Tem-se a percepção de que a prática que envolveu esse processo se acentuou pela aquisição dos saberes operacionais em detrimento dos saberes necessários para educação do futuro, que, conforme já pontuado, devem levar o educando a construção/reconstrução do seu próprio conhecimento em detrimento do ensino bancário e fragmentado; proporcionar o entendimento global e local que permitam conhecer os problemas do mundo e do seu entorno; apreender o objeto em seu contexto, sua complexidade, seu conjunto. (MORIN, 2001);

Os pressupostos de que as Políticas Públicas devem ser concebidas como um processo composto por um conjunto de atividades, nos quais o monitoramento e avaliação são essenciais (Rodrigues, 2010), não foram adequadamente aplicados, pois muitos problemas relacionados à deficiência de acompanhamento e avaliação foram percebidos, tanto nos documentos do MTur como na pesquisa em campo.

Em tempo, se essas políticas foram planejadas tendo como base atender ao mundo do trabalho e aumentar a geração de emprego e renda, isto não se configura, uma vez que alguns cursos ofertados não encontram coerência com o mundo formal de trabalho, o que acaba por iludir uma parcela de sujeitos que buscam na qualificação uma oportunidade de trabalho e renda, mas na prática, apesar de existir tais demandas, estas são informais, deixando o trabalhador descoberto de seus direitos por não estar reconhecido na legislação trabalhista correspondente, o que acaba por inviabilizar a oferta desses cursos.

Foi observado que a constituição dos cursos FIC do Eixo turismo, hospitalidade e lazer se deu a partir da capilaridade das instituições de ensino, ou seja, o catálogo de cursos FIC foi definido por essas instituições. Sendo comum o entendimento de que as ofertas disponibilizadas, pelo PRONATEC Turismo, em sua maioria, foram desencontradas das necessidades de qualificação dos sujeitos, conforme se verifica nas evidências encontradas pela entrevista com alguns gestores: "algumas vezes a gente viu cursos que estavam no catálogo, que tinham uma grande procura, mas que os ofertantes não tinham condições, ou porque eram cursos caros, sommelier, sushiman, que demandavam insumos, um local 
apropriado" (gestor c); "a escolha do curso se deu a partir da disponibilidade da oferta" (gestor a).

Tem-se na prática um processo de elaboração de políticas públicas desconexos das diversas realidades do país, no qual as ações são planejadas e implementadas, muitas vezes, desencontradas das efetivas demandas. Ocasionando apenas ações compensatórias que não conseguem atingir resultados efetivos.

Apresentam-se como premissas das políticas públicas primordiais para 0 desenvolvimento humano e social do país as políticas educacionais, componentes das políticas públicas sociais, que visam uma maior qualidade de vida para a sociedade, tendo em vista que a educação consiste de ferramenta capaz de elevar a autoestima dos cidadãos e proporcionar a sua autonomia como ser social. (PARENTE, 2010).

Configura-se mais uma vez que os interesses dominantes estão acima dos interesses gerais da sociedade, ou seja, o interesse das instituições de ensino prevaleceram, fazendo jus ao que salienta Saviani (1983 p. 35) "a escola é determinada socialmente; a sociedade em que vivemos fundada no modo de produção capitalista é dividida em classes com interesses opostos; portanto, a escola sofre a determinação do conflito de interesses que caracteriza a sociedade."

"O curso PRONATEC é muito equivocado para o perfil do aluno, não existe um encaminhamento e sem muito objetivo é somente números para o governo" (gestor a).

Essa evidência demonstra as consequências de políticas de qualificação que se restringem a obtenção de resultados quantitativos. A falta de compreensão sobre a importância em relação à articulação trabalho e formação profissional, comina na baixa qualidade dos cursos ofertados e na percepção de que as ações foram apenas compensatórias para mitigar a baixa escolaridade e o desemprego presentes na sociedade brasileira.

A formação profissional tem como um de seus pilares o pensar e o agir (ação e aprendizado participativo), o que promove um diálogo mais eficaz entre o saber técnico e o saber fazer, por vezes tradicional, burocrático, setorializado dos profissionais que atuam na gestão do turismo. As ações de qualificação/formação 
profissional tem relação direta com o trabalho humano, que exige um determinado grau de reflexão. Ainda que, degradado e mecânico, exige um mínimo de atividade intelectual criativa. "Dominar uma operação manual requer ação, às vezes, decisão, exigindo certa reflexão sobre o que fazer, como fazer, como resolver os imprevistos e prosseguir". (MOESCH, 2016, p.72).

Ademais, toda proposta política deve ser adequadamente planejada, buscando atender as camadas sociais para viabilizar a sua implementação e resultados mais efetivos, conforme aponta Kaplan, 1971.

Dados detectadas na pesquisa em campo demonstram como o processo de implementação do Programa ocorreu sem o devido planejamento, não atendendo as demandas dos trabalhadores por uma educação que lhes possibilitasse construir carreiras e contribuir para o desenvolvimento integrado do turismo.

"Os programas carecem de uma sintonia fina entre o que é ofertado em termos de cursos de qualificação profissional e os interesses da comunidade; entre o perfil profissional do aluno egresso e as necessidades do arranjo produtivo local" (professor a).

Permanece perceptível a falta alinhamento dos cursos ao contexto no qual o turismo se insere e suas dinâmicas. Os cursos não conseguiram se alinhar as demandas da educação do futuro que atendessem igualmente as premissas para a construção do conhecimento científico, técnico e operacional, alinhado a formação para autonomia e emancipação dos sujeitos.

As competências e qualificações para o trabalho estão cada vez mais avançadas, os empregos exigirão qualificações mais específicas e elevadas. A tecnologia demandará além das competências básicas, aptidões para a criatividade, a inovação e a solução de problemas, elementos essenciais para o turismo. (PNUD, 2015).

Em outra oportunidade confirmou-se o que vem sendo apontado nesta pesquisa, o Programa foi planejado para atender as demandas do mercado, conforme relato:

Houve uma consulta aos membros do Conselho de Turismo do Recife para identificar as necessidades de formação (habilidades, competência e conhecimentos) e que eles escolheram as formações que seriam prioritárias. A partir dessa demanda, a Secretaria enviou a solicitação ao 
MTUR, mas é importante ressaltar que as vagas não vieram de acordo com esse pedido; (Gestor d).

O planejamento, que de acordo com Gross (1971) consiste de decisão prévia ou pressão externa (demandas da sociedade para resolver um problema estrutural), podendo ser espontâneo, negligente ou ocasional, se restringiu apenas a uma parcela (mercado) da sociedade que possui maior força para se fazer representar, assim o Programa se configurou numa ação pontual que não conseguiu atingir os efeitos desejáveis em prol do desenvolvimento endógeno do turismo.

Verifica-se ainda no discurso de alguns professores a inadequação entre o planejamento e a realidade da formação profissional nas localidades: "é preciso que haja uma formatação mais adequada em relação aos cursos. $O$ alto índice de evasão, o baixo aproveitamento pelo mercado e o desinteresse dos alunos na obtenção do conhecimento, são pontos que reforçam a necessidade de readequação" (professor b).

O relato corrobora com o entendimento de que os benefícios da qualificação e do aperfeiçoamento profissional somente serão alcançados se o governo e a iniciativa privada oferecerem em parceria programas de educação profissional que promovam não só a aplicação de conteúdos técnicos e operacionais, mas, sobretudo que proporcionem uma qualificação ao longo da vida, como forma de buscar uma educação libertadora e emancipatória.

[ ] educação que desvestida de roupagem alienada e alienante, seja uma força de mudança e de libertação. A opção, por isso, teria de ser também, entre uma educação para a domesticação, para alienação, e uma educação para a liberdade. Educação para o homem-objeto ou educação para o homem-sujeito. (FREIRE, 1977, p. 36).

A Política de qualificação profissional não se atentou para as necessidades dos trabalhadores, que não são apenas emprego e renda, mas por um trabalho digno, conforme aponta o PNUD (2015).

Conforme aponta os Quatros Pilares da Agenda do Trabalho Digno (PNUD, 2015):

i. Criar emprego e desenvolver as empresas. A principal via para sair da pobreza é a existência de postos de trabalho e é imperioso que a economia 
proporcione oportunidades de investimento, empreendedorismo, criação de emprego e meios de subsistência sustentáveis.

ii. Estabelecer normas e direitos no trabalho. É preciso que existam oportunidades de representação que permitam às pessoas participar e expressar os seus pontos de vista a fim de conquistar direitos e respeito.

iii. Proteção social. A proteção social de base, como os cuidados de saúde e a segurança, constitui a fundação para uma participação produtiva na sociedade e na economia.

iv. Oportunidades de governação e diálogo social. O diálogo social entre governos, trabalhadores e empregadores pode resolver problemas econômicos e sociais importantes, encorajar a boa governação, criar relações de trabalho sólidas e impulsionar o progresso econômico e social.

O setor de turismo e hospitalidade, devido a sua dinâmica econômica e social, tem prerrogativas para atender as necessidades dos trabalhadores para se desenvolverem e crescerem profissionalmente, pois há oportunidades em vários segmentos de pequenos negócios a partir das qualidades e competências culturais e territoriais, que possibilitam a interação desses sujeitos com o mundo. Possui ainda condições para ofertar um trabalho digno e uma maior participação cidadã, por ser uma prática social onde as relações sociais entre trabalhadores e turistas acontecem frequentemente gerando trocas culturais, conhecimentos e aprendizados diários nas localidades.

Para a inclusão social pelo turismo é fundamental que os processos educativos/formativos sejam abrangentes e não apenas centrados em procedimentos de aprendizado bancário, no qual os sujeitos quando absorvem os conhecimentos, muitas vezes nem sequer conseguem transmutá-los para sua realidade.

A educação profissional deve ser integral problematizadora, ou seja, permitir aos sujeitos não apenas executar tarefas e desenvolver competências e habilidades básicas para o trabalho, mas ter uma consciência crítica sobre a dinâmica do mundo do trabalho, para que possam interagir e tomar decisões que assegurem sua emancipação . 
Conforme aponta a UNESCO (1998) a educação cidadã e o trabalho digno são determinantes, pois consiste de educação que tenha como objetivo principal preparar os sujeitos para compreender o mundo, desenvolver suas capacidades profissionais e comunicar, colocar em prática os conhecimentos adquiridos, participar e cooperar em sociedade; e, desenvolver-se, agir com autonomia, discernimento e reponsabilidade.

Entretanto na política pública de qualificação empreendida pelo MTur nos últimos anos percebe-se que essas proposições não foram devidamente valorizadas ao se verificar o foco que esta conotado nos documentos do Ministério, como na Portaria $n^{\circ}$ 76, de 20 de maio de 2015: §1ㅇ o PRONATEC Turismo está sendo implementado de forma progressiva, com vistas à melhoria contínua dos serviços prestados ao turista $^{61}$. (Brasil 2015t).

Com base nas evidências desta pesquisa constata-se que política de qualificação profissional, PRONATEC Turismo, focou, prioritariamente, no aumento da competitividade dos destinos turísticos, por meio da qualidade dos serviços prestados aos turistas, sem atentar-se que isso depende invariavelmente dos trabalhadores, que em nenhum momento foram referenciados, a única exceção foi quando se tratavam de critérios para elaboração da "demanda" para participação nos cursos.

Outro fator de desacerto foi considerar o número de matrículas como indicador de efetividade, entretanto a relação de efetividade/eficiência deveria estar atrelada à inclusão social dos trabalhadores pela elevação da escolaridade e à continuidade do processo de ensino aprendizagem. Entende-se que apenas matricular, sem acompanhar a efetividade do processo de formação e as causas da evasão, não agrega valor a um processo de mudança pretendido com a execução do PRONATEC: "garantir trabalhadores mais preparados e qualificados para o mercado de trabalho, possibilitando agregar valor ao sistema produtivo do País". (Brasil, 2001d).

\footnotetext{
${ }^{61}$ Grifo nosso.
} 
A educação para a inclusão social e desenvolvimento humano não está contemplada pelos objetivos do Programa, o que 0 distancia enquanto desdobramento da Política Nacional de Qualificação.

A totalidade/fragmentação do processo de implantação do PRONATEC turismo, foi decorrente da dinâmica que o envolveu, tais como:

i. Falta de planejamento, monitoramento e avaliações periódicas que fica evidenciado nos discursos dos sujeitos envolvidos com a implementação do Programa:

"Falhamos em não ter um monitoramento, encaminhamento para um emprego" (gestor e); "não ocorreu avaliação pelo instituto durante a realização dos cursos" (gestor f); "existe uma avaliação realizada por meio de questionário junto aos alunos para avaliar os professores" (professor $\mathrm{c}$ ).

Cabe ressaltar que o processo que envolve a concepção das políticas públicas deve atentar-se para todas as etapas/estágios envolvidos desde a formulação, a implementação, o monitoramento até a avaliação, (Rodrigues, 2010), não de pode conceber tal processo de forma trincada, sem ter como fim atender as demandas e interesses da sociedade.

Corrobora com esses entendimentos o que está pontuado na Análise Documental (BRASIL 2014cc) a existência de baixa presença de modelos de avaliação, monitoramento e indicadores, fator que distancia a política proposta de um processo de elaboração e implementação de políticas sociais que precisam ser acompanhadas, monitoradas e avaliadas para possibilitar a identificação das possíveis falhas em tempo de corrigi-las, bem como permitir identificar seu legado para futuras propostas.

Ademais o processo de monitoramento e avaliação na implementação do Programa, quando ocorreu esteve centrado em números: quantidade de alunos, de evasão, de egressos, de material entre outros fatores, deixando a desejar quanto a se constituir em um procedimento sistemático para aferir os resultados desejados, no caso: geração de emprego, inclusão social, desenvolvimento humano, melhoria dos serviços, aumento da competitividade entre outros que não tinham sequer condições de serem medidos. 
Além disso, por falta de acompanhamento e avaliação não se sabe o resultado efetivo do Programa, tampouco se esse processo possibilitou à agregação de valor ao trabalho no setor, ou seja, se foi efetivo para a inclusão social do trabalhador e, consequentemente para o desenvolvimento humanizador pelo turismo.

$\mathrm{Na}$ iminente necessidade de resultados contundentes para a sociedade não se pode admitir políticas públicas que não apresentem resultados, que sejam apenas lançadas visando uma aparente solução. Faz-se urgente acertar o rumo, fazer proposições adequadas para a sociedade como um todo e possibilitar a participação cidadã em todas as suas fases: elaboração, implementação, monitoramento e avaliação, permitindo o exercício da criticidade. Conforme Demo (1995) para ponderar os fatos ocorridos no movimento histórico, se estabelece a crítica, atentando que a coerência da crítica está na autocrítica, pois não é possível criticar sem apresentar-se como criticável. Assim, a crítica se completa na contraproposta (soluções). Não é aceitável a mera crítica, destrutiva, sem compromisso com alguma construção concreta.

ii. Indefinições de papeis e dos ajustes para atender as necessidades dos trabalhadores por uma educação integral que Ihes possibilitassem a autonomia e a emancipação, como aponta a teoria que embasa este estudo: um dos requisitos fundamentais para o desenvolvimento humano é a educação/formação integral dos sujeitos, que tenham como objetivo a cidadania, a liberdade, a autonomia e a emancipação, conforme referências contidas em Freire (1977; 1996); Frigotto (2001); Gentilli; Frigotto (2000); Kunzer (1991); Saviani (1983).

Os cursos tem antes de tudo o papel de formar cidadãos trabalhadores, que contribuam com a sua localidade. Que sejam estimulados a pensar criticamente, a buscar mudar o que não consideram estar bom, ser mais ativo socialmente. Inserir nos cursos de qualificação em turismo disciplinas voltadas a formação cidadã, ao papel do ser social na busca da melhoria do lugar, a importância da atividade para a sociedade etc. é um caminho. (professora d).

Para isso a educação deve trabalhar também com os saberes adquiridos ao longo da vida, respeitando os fatores histórico-cultural e social dos sujeitos, integrando-os aos processos educativos. Possibilitando a construção/reconstrução 
do conhecimento pelos indivíduos, bem assim ensinar a visão global e local do mundo, aprender o objeto em seu contexto, complexidade e conjunto, transmitir as ideias essenciais para a construção de um cidadão participativo, que entenda e respeite as diferenças, apontamentos de Morin, 2001 e PNUD, 2015.

Com base nos resultados deste estudo não foi possível perceber (salvo raras exceções que foram consideradas boas práticas do Programa, as quais serão detalhadas em subitem específico) ações que potencializassem a efetiva inclusão social, que não se constitui apenas pela geração de emprego e renda.

A inclusão social se relaciona diretamente com a procura da estabilidade social, através da cidadania social, pressuposto para uma educação cidadã, na qual todos devem buscar os mesmos direitos em sociedade, ou seja, o bem-estar das pessoas como cidadãos. (SHEPPARD, 2006).

Visando (des)construir para (re)construir, processo inerente a análise dialética, propõem-se uma adaptação aos fatores relacionados à inclusão social, ligados ao setor de turismo e hospitalidade, conforme se apresenta no esquema 2, abaixo:

Esquema 2 - Fatores para a Inclusão Social

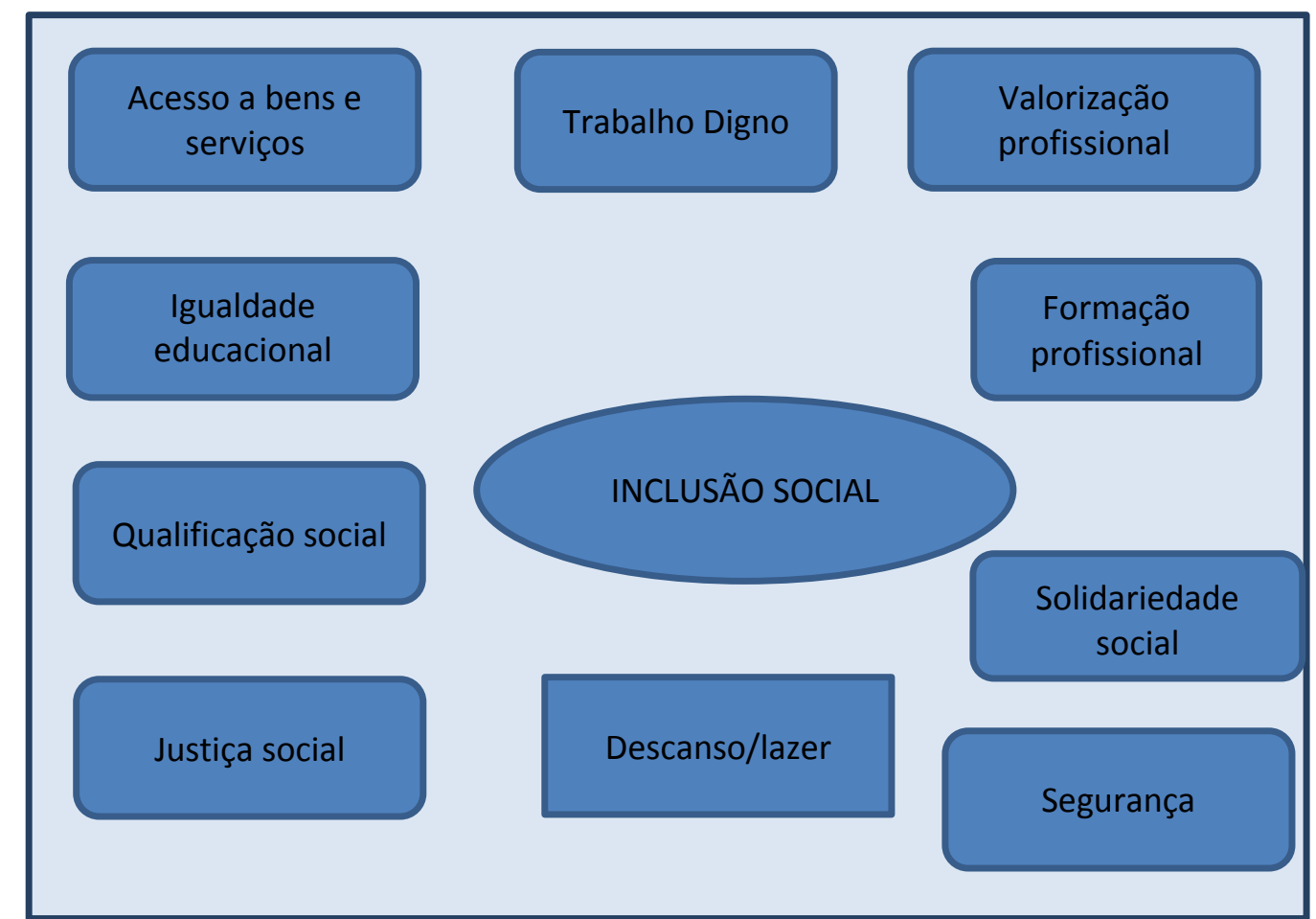

Fonte: elaborada pela autora com base nos Fatores de inclusão social: Revista Serviço Social e Sociedade: São Paulo no 106, p. 219-240, abr./jun., 2011. 
Entende-se que a inclusão dos sujeitos é determinante para uma vida ativa e o equilíbrio das oportunidades em sociedade, considerando que essa inclusão prioritariamente começa pelo acesso ao emprego qualificante, possibilitador do crescimento profissional, espaço onde o trabalhador possa criar, desenvolver-se e ter suas individualidades respeitadas. Acesso aos direitos sociais, políticos, civis, econômicos, culturais e ao lazer. (CASALI, 2007; PNUD, 2015).

Ao se fazer o cruzamento dos cursos ofertado versus conteúdos dos planos de cursos, foi possível detectar que as questões relativas à cidadania foram pouco tratadas. A sistematização (quadro 10) demonstra essa avaliação:

Quadro 10 - Cursos e grade curricular

\begin{tabular}{|c|c|c|c|}
\hline & \multicolumn{3}{|c|}{ Cursos de Qualificação } \\
\hline $\begin{array}{c}\text { Cursos de } \\
\text { Qualificação }\end{array}$ & \multicolumn{3}{|c|}{ Grade curricular - Guia FIC } \\
\hline $\begin{array}{l}\text { Recepcionista } \\
\text { em meios de } \\
\text { hospedagem }\end{array}$ & $\begin{array}{l}\text { INSTITUTO FEDERAL } \\
\text { ENSINO MEDIO } \\
\text { INCOMPLETO } \\
\text { 1. Fundamentos da } \\
\text { Hospitalidade e do } \\
\text { Turismo } \\
\text { 2. Operação de Recepção } \\
\text { 3. Relações Interpessoais } \\
\text { e Imagem Pessoal } \\
\text { 4. Linguagem e } \\
\text { Comunicação } \\
\text { 5.Técnicas de Dicção e } \\
\text { Oratória Aplicadas ao } \\
\text { recepcionista em meios } \\
\text { de hospedagem } \\
\text { TOTAL } 160 \mathrm{~h}\end{array}$ & $\begin{array}{l}\text { INSTITUTO FEDERAL } \\
\text { ENSINO MEDIO } \\
\text { INCOMPLETO } \\
\text { 1. Fundamentos da } \\
\text { Hospitalidade e do Turismo } \\
\text { 2. Operação de Recepção } \\
\text { 3. Relações Interpessoais e } \\
\text { Imagem Pessoal } \\
\text { 4. Linguagem e } \\
\text { Comunicação } \\
\text { 5.Técnicas de Dicção e } \\
\text { Oratória Aplicadas ao } \\
\text { recepcionista em meios de } \\
\text { hospedagem } \\
\text { TOTAL } 160 \mathrm{~h}\end{array}$ & $\begin{array}{l}\text { INSTITUTO]FEDERAL } \\
\text { ENSINO MEDIO } \\
\text { INCOMPLETO } \\
\text { 1. Introdução ao Turismo e } \\
\text { Hotelaria } \\
\text { 2.Ética e Relações } \\
\text { interpessoais nos meios de } \\
\text { hospedagem } \\
\text { 3.Inglês Instrumental } \\
\text { 4.Organização Hoteleira I } \\
\text { 5.Integração e Orientação } \\
\text { Profissional } \\
\text { 6.Técnicas de atendimento } \\
\text { ao cliente e assistência ao } \\
\text { turista } \\
\text { 7.Organização Hoteleira II } \\
\text { 8.Segurança no Trabalho } \\
\text { 9.Legislação Turística } \\
\text { TOTAL 200h }\end{array}$ \\
\hline
\end{tabular}




\begin{tabular}{|c|c|c|c|}
\hline $\begin{array}{l}\text { Camareira em } \\
\text { meios de } \\
\text { hospedagem }\end{array}$ & $\begin{array}{l}\text { ENSINO FUNDAMENTAL } \\
\text { COMPLETO } \\
\text { 1.Fundamentos de } \\
\text { Turismo e Hospitalidade } \\
\text { 2.Atendimento ao Cliente } \\
\text { 3.Ética, Cidadania e } \\
\text { Relações 5.Interpessoais } \\
\text { 4.Técnicas de limpeza, } \\
\text { higienização e arrumação } \\
\text { de unidades habitacionais } \\
\text { 5.Saúde e Segurança do } \\
\text { Trabalho } \\
\text { 6.Informatica Básica } \\
\text { 7.Leitura e Produção de } \\
\text { Texto } \\
\text { 8.Serviços de Setor de } \\
\text { Governança }\end{array}$ & $\begin{array}{l}\text { ENSINO FUNDAMENTAL } \\
\text { COMPLETO } \\
\text { 1.Leitura e Produção de } \\
\text { Textos } \\
\text { 2.Matemática Básica } \\
\text { 3.Língua Estrangeira } \\
\text { (Inglês Aplicado à } \\
\text { Hotelaria) } \\
\text { 4.Informática Básica } \\
\text { 5.Relações Interpessoais } \\
\text { 6. Cidladania } \\
\text { 7.Ética Profissional } \\
\text { 8.Qualidade de Vida no } \\
\text { trabalho } \\
\text { 9.Introdução ao Turismo e } \\
\text { à Hospitalidade } \\
\text { 10.Rotinas e Técnicas do } \\
\text { Trabalho de Camareira em } \\
\text { Meios de Hospedagem } \\
\text { 11.Seminários de Prática } \\
\text { Profissional }\end{array}$ & $\begin{array}{l}\text { SENAC } \\
\text { Revisão de tecnicas } \\
\text { I - Atribuições da Camareira } \\
\text { II - Material de Trabalho } \\
\text { III - Higienização e } \\
\text { Arrumação } \\
\text { TOTAL: } 20 \text { horas }\end{array}$ \\
\hline
\end{tabular}

Evidencia que as questões da cidadania foram pontuais na grade curricular dos cursos ofertados, sendo unânime a prevalência dos conteúdos relacionados à aquisição de competências para o exercício de uma função específica do mercado de trabalho do setor, sem haver distinção nos conteúdos destinados aos trabalhadores do setor e aos desempregados em busca de oportunidade de trabalho. O que demonstra mais uma vez o distanciamento do Programa de uma política social efetiva.

Nesse percurso nota-se que existem fatores que predominam junto à categoria dialética da autonomia/dependência, na qual a manifestação do sujeito em sociedade ocorre pela interação deste com o contexto de sua realidade, essa relação não ocorre de forma individual e específica, está sempre relacionada com os objetos, pela interação parcial e concreta, aceita pela sociedade ou grupos sociais no qual estão inseridos, a exemplo das falas dos entrevistados:

"Conclui o curso superior em turismo, não encontrei oportunidades de emprego na área" (egresso a); Mostra que a conjuntura social implica na progressão social.

"A formação adquirida ajudou os alunos a serem mais competitivos no mercado de trabalho. Muitos seguiram seus estudos no idioma" (professor d). Esta 
visão coaduna com a ideia de educação pautada no trabalho visando o aumento da competitividade quer seja do setor, como do profissional. Neste entendimento prevalece à valorização do ensino técnico e operacional por entender que o desenvolvimento de competências garante uma maior competividade no mercado de trabalho.

"Consegui estágio após o curso e trabalho indiretamente na área" (egresso c), tem-se aqui a autonomia detectada na fala desse egresso que em que pese os problemas conjunturais do Brasil, conseguiu avançar.

\begin{abstract}
Enfatizamos que a produção do espaço é a produção do tempo histórico com certas nuances, aqui e ali, mas suas diversas conformações contraditórias (que fogem às mãos dos sujeitos) agem de forma a contribuir com movimentos conflitivos que, por um lado, conduzem à reprodução da forma societária via renovadas tentativas de naturalizá-la e eternizá-la por uma ideologia no e do espaço, e, por outro, tendem a solidificar ações que questionem tais tentativas quando exacerbadas, principalmente naqueles momentos em que as promessas e ações políticas paliativas-reformistas (tanto da direita como da "esquerda" governante) e o poder de polícia não se mostram suficientes frente a um alto grau de exploração do trabalho e da consequente disparidade-degradação que os processos de acumulação estampam nas tramas sociais e geográficas. (MARTONI, 2014 p.13-14).
\end{abstract}

Além das evidências verificadas na análise das entrevistas com os egressos dos cursos, nas quais se infere que o ciclo virtuoso para inclusão social, construção de carreiras, reconhecimento, foi pouquíssimo alcançado, na análise documental, de acordo com o apresentado na figura 13, dos alunos que concluíram os cursos do PRONATEC Turismo 53\% não conseguiram ser inseridos no mercado de trabalho ou em atividades econômicas do setor. Verifica-se um resultado insatisfatório relacionado à empregabilidade desses egressos, na qual apenas $10 \%$ conseguiram colocação no setor de turismo e hospitalidade. 


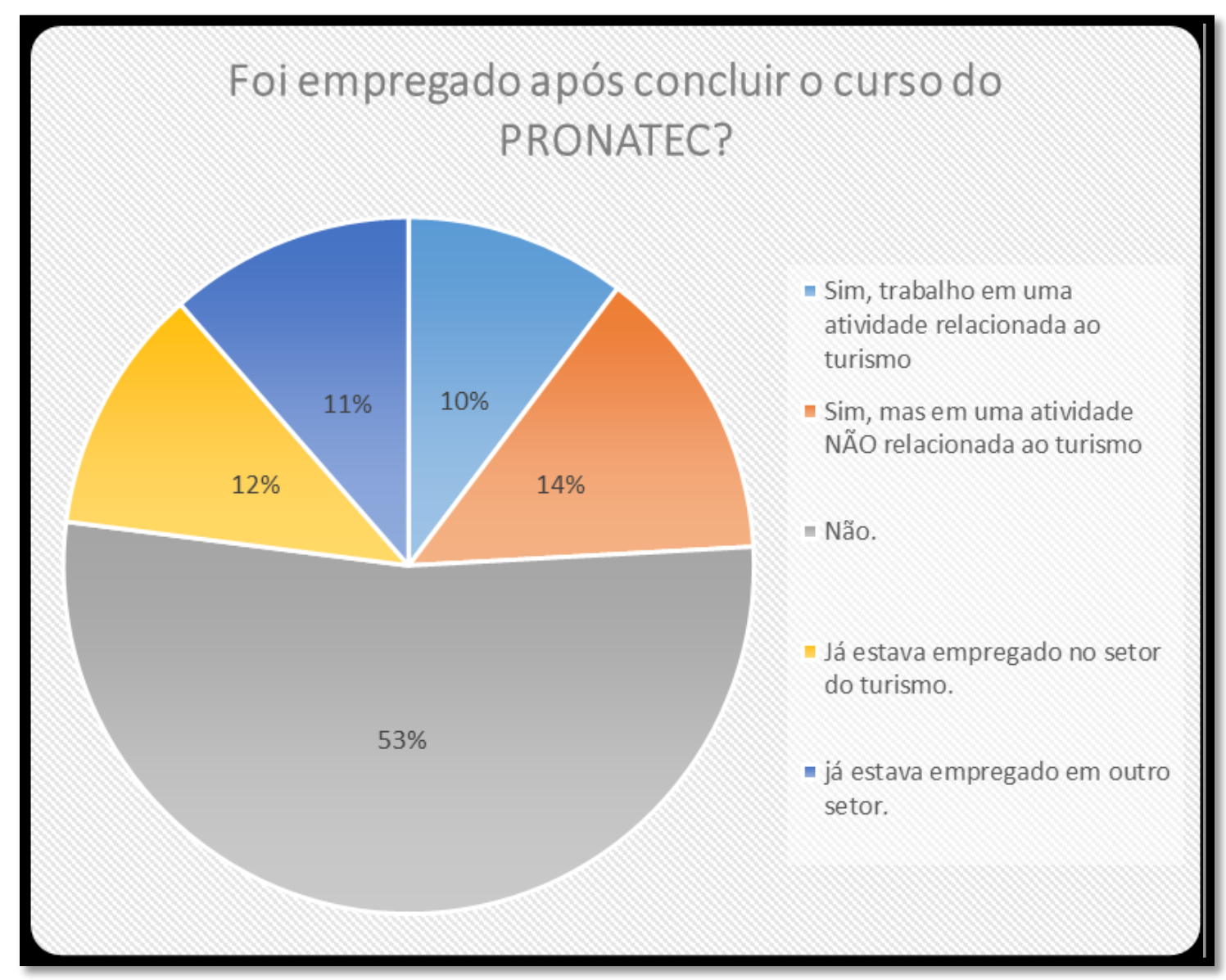

Fonte: Minuta de relatório de avaliação de resultados: PRONATEC turismo (2012-2014), 2015.

O distanciamento entre a intencionalidade da relação formaçãoempregabilidade contribuiu para que os efeitos do Programa percebidos pela sociedade fossem fragmentados, derivados dessas convergências e divergências, as quais se verificam nas falas dos entrevistados: "muitos estavam lá, pois na época estavam recebendo seguro desemprego e tinha que estar fazendo um curso" (professor e); "muitas se formaram no curso do PRONATEC, então seguiram para o estágio e muitos agora estão trabalhando" (professor f); "tem muita evasão [...] as turmas começavam com 40 (45) e terminavam com 12, 13. Eu acho que é por causa do perfil, que não se enquadravam" (professor g); "trabalhei para uma empresa no setor durante a copa do mundo de 2014" (egresso d); "após o curso estou fazendo 
tecnologia em eventos" (egresso e); "poucos egressos empregados. O profissional do Turismo é mal remunerado e isso dificulta muito" (professor g).

O setor de turismo e hospitalidade "além de pagar salários inferiores à média nacional, as ocupações turísticas caracterizam-se por estarem nas posições mais baixas da pirâmide salarial brasileira". (OURIQUES, 2005, p.130 apud MARTONI, 2014 p. 205) $)^{62}$.

O salário mínimo em janeiro de 2014 foi de $R \$ 724,00$, todas as ocupações do setor com exceção de "gerente de hotel", "gerente de restaurante" (masculino), "organização de eventos" (feminino), "turismólogo" e "gerente de turismo" tiveram vencimentos abaixo de dois mínimos. Os dados citados são pautados por uma média salarial que fica em torno do mínimo nacional 1,27 salários mensais. (MARTONI, 2014).

Segundo dados do IPEA 67\% dos trabalhadores do setor recebem até dois salários mínimos, corrobora com essa informação o que aponta Martoni (2014 p. 175) "há uma organização da classe empresarial com vistas a nivelar o preço da força de trabalho abaixo do seu valor".

O mercado nivela por baixo os trabalhadores do setor, preferindo a informalidade e os contratos temporários, que representam menos custos. $\mathrm{Na}$ contramão sabe-se que o turismo carece de pessoal qualificado e de profissionalismo, para agregar valor junto aos produtos e serviços, mas, para isso é necessária uma mudança de mentalidade quer do setor público, por meio de políticas inclusivas destinadas aos trabalhadores de turismo e hospitalidade, quer do privado pela valorização e oferecimento de melhores condições de trabalho.

Percepção presente nos discursos: "as pessoas prestam serviço, grande maioria não tinha um vínculo formal de emprego" (gestor c); "carga de trabalho muito extensa" (egresso b).

Conforme constatado a execução do PRONATEC Turismo se mostrou recheada de contradições/mediações, de acordo com Demo (1990), toda formação social é contraditória sendo a formação social uma realidade que se forma

\footnotetext{
62 OURIQUES, Helton Ricardo. A produção do turismo: fetichismo e dependência. Campinas: Alínea, 2005.
} 
processualmente, na história, cujo aspecto formativo histórico é sempre dinâmico, na unidade dos contrários. (MOESCH, 1999).

Como na dialética a formação social é contraditória, DEMO (1990), sendo a formação social uma realidade que se forma processualmente, na história, cujo aspecto formativo histórico é sempre dinâmico, na unidade dos contrários (MOESCH, 1999), algumas práticas exitosas do PRONATEC Turismo foram identificadas nas entrevistas com egressos dos cursos. Os casos de sucessos identificados conseguiram romper essa totalidade para construir uma nova práxis que possibilitou o desenvolvimento humano dessas pessoas e a consequente inclusão social, conforme se verifica no quadro 11 abaixo: 
Quadro 11 - Boas práticas para o desenvolvimento humano pelo Turismo

\begin{tabular}{|c|c|c|c|c|c|c|c|c|}
\hline \multicolumn{3}{|c|}{ CATEGORIAS A PRIORI } & \multicolumn{6}{|c|}{ CATEGORIAS MATERIALISMO HISTORICO-DIALETICO } \\
\hline Categorias & Concepções & Avanços & Teoria/prática & $\begin{array}{c}\text { Totalidade } \\
\text { fragmentação }\end{array}$ & $\begin{array}{c}\text { Contradição } \\
\text { mediação }\end{array}$ & $\begin{array}{c}\text { Subjetividade } \\
\text { objetividade }\end{array}$ & $\begin{array}{c}\text { Autonomia } \\
\text { dependência }\end{array}$ & $\begin{array}{l}\text { Criticidade } \\
\text { alienação }\end{array}$ \\
\hline $\begin{array}{l}\text { Educação profissional } \\
\text { possibilitadora da } \\
\text { construção de carreiras no } \\
\text { setor: concepções de } \\
\text { educação/formação } \\
\text { profissional, focada nos } \\
\text { sujeitos e não apenas na } \\
\text { produção e no capital. Em } \\
\text { que sejam valorizadas as } \\
\text { potencialidades humanas, } \\
\text { a educação } \\
\text { problematizadora, } \\
\text { emancipatória e cidadã, } \\
\text { que permita desenvolver } \\
\text { competências não só para } \\
\text { o trabalho, como também } \\
\text { para a vida, em detrimento } \\
\text { da educação bancária, } \\
\text { focada em treinamento. } \\
\text { Com uma nova postura na } \\
\text { educação profissional será } \\
\text { possível enxergar o } \\
\text { trabalho no Turismo como } \\
\text { oportunidade interessante, } \\
\text { gratificante e criativa, no } \\
\text { qual os sujeitos podem } \\
\text { desenvolver-se } \\
\text { permanentemente pelas } \\
\text { relações de troca e } \\
\text { aprendizado constante que } \\
\text { o setor pode proporcionar. } \\
\text { Pela formação de um }\end{array}$ & & $\begin{array}{l}\text { "Tenho } \\
\text { vontade de } \\
\text { voltar a } \\
\text { estudar, } \\
\text { realizar } \\
\text { uma } \\
\text { graduação } \\
\text { na área." } \\
\text { "foi possível } \\
\text { despertar } \\
\text { para a área } \\
\text { de turismo } \\
\text { a partir } \\
\text { desse } \\
\text { curso." } \\
\text { "Estou } \\
\text { cursando } \\
\text { Turismo na } \\
\text { UFPR" } \\
\text { "fiz um } \\
\text { curso de } \\
\text { somellier } \\
\text { após o de } \\
\text { bartender" } \\
\text { Fez o curso } \\
\text { de } \\
\text { organizador } \\
\text { de eventos, }\end{array}$ & $\begin{array}{l}\text { "O curso } \\
\text { possibilitou a } \\
\text { entrada no } \\
\text { curso de } \\
\text { tecnologia de } \\
\text { eventos no } \\
\text { IFBA". } \\
\text { "Após o curso } \\
\text { estou fazendo } \\
\text { tecnologia em } \\
\text { eventos." } \\
\text { "voltei a } \\
\text { estudar no } \\
\text { IFBA, curso } \\
\text { tecnológico } \\
\text { em meios de } \\
\text { hospedagens." } \\
\text { "com a base } \\
\text { do curso } \\
\text { consegui } \\
\text { passar no } \\
\text { vestibular." } \\
\text { "o curso é } \\
\text { uma } \\
\text { oportunidade } \\
\text { para o aluno e } \\
\text { traz uma } \\
\text { perspectiva de }\end{array}$ & $\begin{array}{l}\text { "O egresso } \\
\text { informa que o } \\
\text { curso ofertado } \\
\text { pela UnP } \\
\text { possibilitou o } \\
\text { seu } \\
\text { conhecimento } \\
\text { s da área do } \\
\text { Turismo e foi o } \\
\text { motivo que o } \\
\text { incentivou a } \\
\text { cursar a } \\
\text { graduação em } \\
\text { Turismo. } \\
\text { "Formação foi } \\
\text { de extrema } \\
\text { importância } \\
\text { para área de } \\
\text { atuação". } \\
\text { "Foi motivador } \\
\text { para buscar } \\
\text { outros níveis } \\
\text { de } \\
\text { escolaridade. } \\
\text { " }\end{array}$ & $\begin{array}{l}\text { "Consegui } \\
\text { trabalho na } \\
\text { área mas } \\
\text { não fiquei." } \\
\\
\text { "Aprendi } \\
\text { certas coisas } \\
\text { que eu não } \\
\text { conhecia, eu } \\
\text { tenho uma } \\
\text { outra visão." }\end{array}$ & $\begin{array}{l}\text { Ressalta que } \\
\text { tem interesse } \\
\text { em participar } \\
\text { de outros } \\
\text { cursos } \\
\text { Pretende } \\
\text { seguir na } \\
\text { profissão da } \\
\text { área de } \\
\text { eventos e } \\
\text { sempre se } \\
\text { especializar. } \\
\text { "pensei em } \\
\text { fazer } \\
\text { graduação } \\
\text { em turismo, } \\
\text { mas não } \\
\text { posso } \\
\text { financeirame } \\
\text { nte." }\end{array}$ & $\begin{array}{l}\text { "trabalho } \\
\text { como } \\
\text { garçonete." } \\
\text { "quero } \\
\text { trabalhar } \\
\text { nessa área." } \\
\text { "fiz um } \\
\text { segundo } \\
\text { curso no } \\
\text { setor." } \\
\text { "Sim, estou } \\
\text { fazendo } \\
\text { esse novo } \\
\text { curso." } \\
\text { "Consegui } \\
\text { estágio após } \\
\text { o curso e } \\
\text { trabalho } \\
\text { indiretament } \\
\text { e na área." } \\
\text { "fiz outros } \\
\text { cursos na } \\
\text { área." } \\
\text { "fiz outro na } \\
\text { área." }\end{array}$ & \\
\hline
\end{tabular}




\begin{tabular}{|l|l|l|l|l|l|l|}
\hline profissional ativo, crítico, & & $\begin{array}{l}\text { identificou- } \\
\text { se e }\end{array}$ & $\begin{array}{l}\text { crescimento } \\
\text { pessoal, e tem } \\
\text { consciente e participativo }\end{array}$ & & \\
poderá se mudar a visão & & $\begin{array}{l}\text { grande } \\
\text { trabalha na }\end{array}$ & & \\
empresarial e lutar pela & área. & & \\
valorização e o & & & & \\
reconhecimento & & & & \\
profissional. & & & & \\
\hline
\end{tabular}

Fonte: elaborado pela autora, 2016 
A teoria necessita de prática e vise versa, são obras complementares, assim de acordo com um dos objetivos do PRONATEC: "ampliar as oportunidades educacionais dos trabalhadores, por meio do incremento da formação e qualificação profissional" (BRASIL, 2011d) buscou-se verificar na prática se o Programa foi propulsor dessa premissa. De acordo com alguns achados de campos, apesar de pontuais, foi possível perceber essa transposição da teoria para prática quando os egressos informaram que os cursos proporcionaram a continuidade da educação formal, premissa que apareceu mais frequentemente:

"o curso possibilitou a entrada no curso de tecnologia de eventos no IFBA" (egresso f); "voltei a estudar no IFBA, curso tecnológico em meios de hospedagens" (egresso q); Estes dois casos de sucesso são oriundos da Bahia, de egressos do IFBA, outro caso foi registrado em Curitiba: "estou cursando Turismo na UFPR" (egresso r); Em outros casos permitiu a continuidade em outro curso profissionalizante: "fiz um curso de somellier após o de bartender" (egresso s).

As dinâmicas da vida não são apenas circular, são muitas vezes contrárias, feitas de divergências e convergências que transformam as realidades (totalidade/fragmentação), isto se evidenciou quando o egresso informa que o curso ofertado possibilitou o seu conhecimento na área do turismo e foi o motivo que o incentivou a cursar a graduação em Turismo: "a formação foi de extrema importância para área de atuação" (egresso i); "o curso foi motivador e proporcionou o crescimento pessoal" (egresso h). Identifica-se pelos discursos desses egressos que o curso para eles teve muita importância, ao sinalizarem que trouxe um crescimento e uma valorização pessoal para suas vidas.

A formação social é contraditória, nesse processo de implantação do PRONATEC Turismo isso foi perceptível verificar: "consegui trabalho na área, mas não fiquei" (egresso o). Para este sujeito o curso foi uma oportunidade concreta de inclusão social por meio do emprego, mas neste caso o próprio egresso não se identificou com o setor.

A realidade social é movida por condições objetivas e subjetivas, porque as histórias são dinâmicas, neste processo se destaca a oportunidade que um curso de qualificação profissional pode propiciar, mas, para obter bons resultados faz necessária também a ação e a vontade dos sujeitos: "tem interesse em participar de 
outros cursos" (egresso h); "pretende seguir na profissão da área de eventos e sempre se especializar" (egresso e); "pensei em fazer graduação em turismo, mas não posso financeiramente" (egresso $\mathrm{n}$ ); "interesse em fazer outros cursos gratuitos na área" (egresso o). É possível perceber nesses casos considerados boas práticas, o despertar do interesse nos egressos em continuar a busca pela sua formação no setor de turismo e hospitalidade, influenciando a sua autonomia em aproveitar as condições oferecidas pelo novo aprendizado para buscar a mudança. (APÊNDICE B).

Quando os sujeitos se manifestam em sociedade há uma interação destes com o contexto social em que estão inseridos, essas situações permitem que os indivíduos ora sejam participativos e autônomos e em outros momentos dependem mais das conjunturas sociais. Com base neste entendimento verificou-se os fatores (autonomia/dependência) nos discursos dos egressos: "trabalho como garçonete" (egresso i); "quero trabalhar nessa área" (egresso h); "fiz um segundo curso no setor" (egresso s); "sim, estou fazendo esse novo curso" (egresso g); "consegui estágio após o curso e trabalho indiretamente na área" (egresso c); "fiz outros cursos na área" (egresso e).

Nestas exposições pode-se perceber autonomia que o curso pode proporcionar a alguns egressos que de algum modo sentiram-se mais confiante e buscaram as oportunidades, enquanto que outros permaneceram em uma situação de dependências das circunstancias externas.

Nesse contexto a educação foi planejada focalizada no treinamento dos trabalhadores para execução de atividades técnicas e operacionais que não exigissem a utilização do pensamento crítico, mas apenas sua força de trabalho. Isto demonstra "a contradição existente entre as forças produtivas e as relações de produção, a contradição entre as classes exploradoras e exploradas", fator inerente à essência da dialética. (Gadotti, 1983 p. 28).

Lastima-se que em pleno século $X X I$ ainda se verifique a predominância desse tipo de ensino, fragmentado, especializado, baseado no desenvolvimento de competências e conhecimentos para postos de trabalho privativos. O turismo por se tratar de um setor de serviços, dentro do modelo capitalista, reproduz uma prática de treinamento compartimentado, "qualificando" pessoas para atuarem em tarefas 
específicas, sem entender a complexidade do fenômeno e suas relações culturais e sociais. A práxis do processo de implantação e execução do PRONATEC Turismo, se constituiu por contradições em relação à importância dos sujeitos no processo de desenvolvimento, cuja superação está condicionada a uma nova visão sobre a formação profissional, na qual a política pública de educação profissional seja concebida com foco na formação integral dos trabalhadores, que supere a visão reducionista de capital humano e o investimento em educação para a produtividade.

A objetividade/subjetividade inerente aos processos sociais verificadas pela ação do PRONATEC Turismo demonstra que para além das condições objetivas, a realidade social é movida igualmente por condições subjetivas, pois a história se "move" por leis necessárias objetivas, mas a par de seu lado objetivo natural, possui o lado subjetivo, ideológico, de conquista humana cultural. Considera-se, assim, as condições objetivas aquelas dadas externamente ao homem, ou dadas sem sua opção própria e consideram-se as condições subjetivas aquelas dependentes da opção humana, a capacidade de construir a história em parte, no contexto das condições objetivas. (DEMO, 1995).

A objetividade/subjetividade da ação/política se verifica nas falas dos sujeitos a respeito das possibilidades de desenvolvimento humano e inclusão social proporcionada: "o curso possibilitou a entrada no curso de tecnologia de eventos no IFBA" (egresso f); "o curso ofertado pela UnP possibilitou o seu conhecimentos da área do Turismo e foi o motivo que o incentivou a cursar a graduação em Turismo" (egresso g); "aprendi certas coisas que eu não conhecia, eu tenho uma outra visão" (egresso h); "trabalho como garçonete" (egresso i); "consegui estágio após o curso e trabalho indiretamente na área" (egresso j).

Ao apontar as contradições do PRONATEC Turismo verifica-se, por ser mais uma ação de qualificação pontual, tendo como prioridade atender demandas urgentes de uma conjuntura dada, que carregou possibilidades de inclusão social de alguns sujeitos participantes como a "entrada" ao mundo formal da educação, sendo oportunidade única de vislumbrar este caminho para sua inclusão social.

Os discursos oficiais do MTur dissociaram-se da prática, a medida que os cursos não conseguiram atender nem mesmo as demandas do setor por um serviço de excelência, muito menos as necessidades dos trabalhadores por uma formação 
integral que Ihes possibilitasse a emancipação e o reconhecimento profissional. Esta prática impossibilitou a efetivação de um ciclo virtuoso que poderia ter sido fomentado pela práxis do trabalho e da educação emancipatória, que propiciasse transformar o conhecimento/regulação em conhecimento/emancipatório (Santos, 2011), ou seja, ir para além do ensino técnico e operacional a caminho de uma educação que torne os sujeitos livres e independentes para agir nas situações de trabalho e em sociedade.

O turismo é uma combinação complexa de inter-relacionamentos entre produção e serviços, em cuja composição integram-se uma prática social com base cultural, com herança histórica, a um meio ambiente diverso, cartografia natural, relações sociais de hospitalidade, troca de informações interculturais. O somatório desta dinâmica sociocultural gera um fenômeno, recheado de objetividade/subjetividade [...] (MOESCH, 2001, 9).

O procedimento de elaboração/implementação da política de qualificação profissional acompanhou as subjetividades inerentes à política pública do turismo, advindo de um processo fragmentado, no qual os interesses dominantes estavam voltados a atender as demandas das empresas do setor. As ações pautaram-se em demandas empresariais locais e parciais, com vistas a aumentar a competitividade e a visibilidade internacional do turismo. Os resultados dessas ações foram poucos perceptíveis pela sociedade, já que não deixou um legado econômico (aumento do emprego e renda), conforme previsto, tampouco social (inclusão social).

A interpretação dialética de teoria e pratica permite pensar as contradições da realidade, o modo de compreender a realidade como essencialmente contraditória e em permanente transformação. (KONDER, 2008).

\footnotetext{
Se a dialética se baseia na historicidade e se só o ser humano é propriamente histórico, de tal forma que somente existe como concretohistórico, isto é, sempre determinado por uma situação histórica concreta, então a dialética só pode encontrar seu pleno sentido na história concreta do ser humano. Não cabe tal pressuposto na natureza, pelo que não faz sentido perguntar-se pela antítese de uma pedra. Uma pedra não é um ser histórico, marcado pelo conflito social (DEMO, 1995, p.91).
}

A realidade é dinâmica e totalizante, sendo que os fatos sociais não podem ser entendidos quando considerados isoladamente, abstraídos do contexto social, político, econômico e cultural, onde o todo é maior que a soma das partes, pois o 
método dialético se realiza plena e rigorosamente na captação do movimento histórico em suas contradições constituintes. (BRUYNE,1977).

A política de qualificação implementada pelo PRONATEC Turismo poderia ter cunhado possibilidades mais concretas para os trabalhadores do setor se incluísse uma visão social na qual o desenvolvimento humano e a inclusão social dos sujeitos fosse prioridade, como: elevação da escolaridade, educação continuada, emancipatória e cidadã, acesso e permanência no mundo do trabalho do turismo e hospitalidade, reconhecimento profissional, políticas de cargos e salários, entre outras demandas urgentes de atendimento, uma vez que se espera um protagonismo maior desses sujeitos, o que somente será possível pela educação.

Entretanto, a trajetória da política pública de qualificação do MTur trouxe experiências advindas de um processo híbrido, no qual erros e acertos se fizeram notar, a articulação estabelecida pelo MTur com os órgãos distrital, municipais e estaduais, somada as instituições ofertantes de qualificação profissional como Institutos Federais de Educação, Ciência e Tecnologia, SENAC e SINE, foi um importante avanço. Bem como trouxe uma nova perspectiva ao Ministério do Turismo quanto à necessidade de se planejar uma política pública de estado que perpasse as mudanças ocorridas comumente no governo e possa se constituir de prioridade para o setor.

\subsection{A POLITICA de QUALIFICAÇ̃̃o PROFISSIONAL DO MINISTÉRIO dO TURISMO: EQUIVOCOS E ACERTOS DE SUA TRAJETÓRIA COMO AÇÃO PROPOSITIVA DE INCLUSÃO SOCIAL}

As políticas públicas de turismo e hospitalidade, idealizadas pelo Ministério do Turismo, atribuíram primordialmente a responsabilidade de desenvolver e aumentar a competitividade dos produtos e destinos turísticos, com o objetivo de alavancar o setor e torná-lo propulsor da economia do país. Suas proposições se concentraram na estruturação da oferta turística, particularmente infraestrutura e sinalização turística, promoção e apoio à comercialização, bem assim na qualificação de produtos e serviços.

A fragmentação e a fragilidade na elaboração das políticas públicas do turismo se faz notar, especialmente ao se referir a Lei Geral do Turismo e aos 
Planos Nacionais do Turismo (PNT's), documentos primordiais para a regulação e estruturação do setor, mas que devido a seu caráter genérico acabam se distanciando da realidade e dinâmica da realidade das localidades.

O Artigo $5^{\circ}$ da citada Lei traça os objetivos que devem ser prioridade para o fomento do turismo nacional, entre esses:

a) reduzir as disparidades sociais e econômicas, promovendo a inclusão social pelo crescimento da oferta de trabalho e melhor distribuição de renda;

b) ampliar os fluxos turísticos, a permanência e o gasto médio dos turistas nacionais e estrangeiros;

c) estimular a criação, a consolidação e a difusão dos produtos e destinos turísticos;

d) criar e implantar empreendimentos destinados às atividades de expressão cultural, de animação turística, entretenimento e lazer e de outros atrativos com capacidade de retenção e prolongamento do tempo de permanência dos turistas;

e) desenvolver diversos segmentos turísticos;

f) implementar o inventário do patrimônio turístico nacional; propiciar os recursos necessários para investimentos e aproveitamento do espaço turístico para permitir a ampliação, a diversificação, a modernização e a segurança dos equipamentos e serviços;

g) propiciar a competitividade do setor por meio da melhoria da qualidade, eficiência e segurança na prestação dos serviços; estabelecer padrões e normas de qualidade, eficiência e segurança na prestação de serviços; promover a formação, o aperfeiçoamento, a qualificação e a capacitação de recursos humanos para a área do turismo, bem como a implementação de políticas que viabilizem a colocação profissional no mercado de trabalho;

A visão de futuro estabelecida pelo PNT sinaliza que o turismo no Brasil contemplará as diversidades regionais, configurando-se pela geração de produtos, proporcionando a expansão do mercado interno e a inserção efetiva do País no cenário turístico mundial. A geração do emprego, ocupação e renda, a redução das 
desigualdades sociais e regionais, e o equilíbrio do balanço de pagamentos. (BRASIL 2003c; 2007b).

Conforme já pontuado verifica-se que a qualificação profissional se constitui de uma prioridade para o MTur, entretanto destinada a alavancar o mercado, não contendo diretrizes que indiquem a preocupação com os profissionais do setor e o seu desenvolvimento profissional e inclusão social.

O Plano aponta ainda que a Copa do Mundo de Futebol FIFA 2014 e os Jogos Olímpicos Rio de Janeiro 2016 são eventos de forte apelo comercial que apresentam desafios e oportunidades excepcionais para o desenvolvimento do turismo. Pois era pretendido com a recepção dos megaeventos oportunizar um legado na promoção dos atrativos turísticos nacionais, bem como a melhoria da infraestrutura e a qualidade dos serviços turísticos.

Tais compreensões apresentam uma visão fragmentada, traduzida em uma compreensão superficial e de senso comum sobre o que é o Turismo como indústria, setor de serviços, setor econômico propulsor de grandes negócios, potencializador de emprego e renda, e capaz de aumentar a competitividade, pela diversidade e qualidade dos produtos e serviços turísticos, leia-se cultura e natureza das localidades, mas, de modo "sustentável" 63 .

As premissas dos documentos analisados advém da concepção epistemológica econômica, adotadas pelo MTur, onde o turismo é um dos setores que visa o investimento, o crescimento das receitas, um alto nível de empregabilidade, estabilidade financeira e eficiência para obter maior resultado do esforço produtivo, pela melhor aplicação da eficiência técnica, do tempo, da qualidade e eficiência na produção e a distribuição equitativa da renda. ${ }^{64}$

Essa ideologia acentua os pressupostos do capitalismo no qual o mundo gira em torno do crescimento econômico, do aumento e acúmulo de rendas, para um pequeno nicho do setor, especialmente, empresários e investidores estrangeiros, que identificam no país uma oportunidade de investimento com alto potencial de retorno financeiro, uma vez que o Brasil possui as características naturais para

\footnotetext{
${ }^{63}$ Grifo nosso: sustentabilidade conceito que vem sendo utilizado vulgarmente, que relaciona aspectos econômicos, sociais, culturais e ambientais, busca suprir as necessidades do presente sem afetar as gerações futuras.

${ }^{64} \mathrm{https}: / /$ professores.faccat.br/moodle/mod/resource/view.php?id=13019
} 
desenvolver a "atividade turística" e "mão de obra" barata e disponível, acentuada pelo baixo nível de escolaridade dos trabalhadores, desvalorização profissional e elevado índice de desemprego. Isto promove a produção de uma superpopulação relativa de assalariados, que estão a serviço da acumulação de capital para uma minoria.

\begin{abstract}
A lei da oferta e da produção de trabalho fica mantida nos trilhos certos; a oscilação salarial, confinada dentro dos limites convenientes à exploração capitalista; e, finalmente, garantida a imprescindível dependência social do trabalhador para com o capitalista. (MARX, 2001, v.II, p.885 apud MARTONI, 2014 p. 164). ${ }^{65}$
\end{abstract}

A concepção que o MTur confere ao turismo prioriza os aspectos econômicos, pelo aumento dos investimentos, das receitas, da entrada, da circulação e permanência dos turistas, em detrimento dos aspectos sociais, que conforme já pontuado neste estudo, precisam ser atendidos na mesma proporção, principalmente quando se entende o Turismo como fenômeno social, portanto humano, no qual os sujeitos são estruturantes da experiência turística. Esta visão simplista confere à economia a responsabilidade total pelo social, entretanto essa premissa tratada de forma isolada não vem respondendo aos anseios dos sujeitos do turismo, tampouco promovendo o desenvolvimento integrado do setor.

"O capital é a potência econômica da sociedade burguesa, que domina tudo [e] deve constituir o ponto inicial e o ponto final a ser desenvolvido" (MARX, 1987, p.22, apud MARTONI, 2014 p. 153 ${ }^{66}$. Tem-se assim uma visão distorcida de que para o turismo se desenvolver satisfaz o aumento das receitas, advindas da configuração de destinos turísticos e da circulação de turistas. Isto se traduz na objetificação das relações humanas e demonstra que a harmonia entre o crescimento e o desenvolvimento do turismo defendido por muitos estudiosos não encontra campo para se estabelecer em seus limites estruturais, podendo adquirir formas dissimuladas, a exemplo do turismo de base comunitária, ou

\footnotetext{
${ }^{65}$ Marx, K. O Capital: crítica da economia política, livro I, volume II. Tradução de Reginaldo Sant'Anna. 17. ed. Rio de Janeiro: Civilização Brasileira, 2001.

${ }^{66}$ Para a crítica da economia política (tradução de José Carlos Bruni, et. al.) 4.ed. São Paulo: Nova Cultural, 1987 (Coleção Os pensadores).
} 
empreendimentos turísticos "sustentáveis" e as ações de qualificação reprodutoras desta exploração do trabalho. (MARTONI, 2014, grifo nosso).

Nesse contexto surge a política pública de qualificação profissional, implementada pelo MTur ao longo de quase 13 anos, que foi consubstanciada por ações cercadas de subjetividade, fragmentação e contradição. O objetivo principal esteve centrado "na melhoraria dos serviços turísticos, como forma de aferir maior competitividade aos destinos". (PNT, 2007). Nesta visão o turismo está centralizado no desenvolvimento econômico, para aferir ganhos materiais e financeiros, buscando na qualificação uma oportunidade de aumentar esses resultados. De tal modo que os profissionais do setor são considerados insumos (mão de obra, capital humano) importantes que carecem de qualificação para atender essas premissas.

Corrobora com esse entendimento o que dispõe a Lei Geral do Turismo em seu Art.11:

Art. 11 criação do Comitê Interministerial de Facilitação Turística com a finalidade de compatibilizar a execução e a consecução das metas do PNT com as demais políticas públicas, de forma que os planos, programas e projetos das diversas áreas do Governo Federal venham a incentivar: inciso VIII "a formação, a capacitação profissional, a qualificação, o treinamento e a reciclagem de mão de obra para o setor turístico e sua colocação no mercado de trabalho" e inciso XII "a geração de emprego". (BRASIL, 2008I).

Complementarmente os Planos Nacionais de Turismo apresentam algumas definições do que deva ser o Programa de Qualificação Profissional e Empresarial:

Conjunto de ações relativas à qualificação dos diversos tipos de profissionais que integram a cadeia produtiva do turismo, bem como ações voltadas à sensibilização da população local quanto à importância de sua participação para o sucesso e o desenvolvimento sustentável.

Apoia a produção de metodologias e ferramentas pedagógicas apropriadas ao desenvolvimento de competências profissionais e à inserção profissional.

A qualificação deve ter como premissa o atendimento à demanda quantitativa e qualitativa do mercado, relativamente aos setores, segmentos e destinos turísticos nas diversas regiões.

Qualificação profissional para melhoria da qualidade dos serviços a serem ofertados aos turistas que visitarão o país nos megaeventos. (BRASIL 2003c; 2007b; 2013z). 
A inserção profissional, por meio da geração de emprego, está arrolada nesses documentos, mas de forma parcial. Não houve indicativos para a inclusão social desses profissionais, deixando de se constituir em uma prioridade dessa política, na medida em que questões de fundo como a valorização profissional, planos de cargos e salários, educação continuada, educação para o trabalho não foram pautadas.

Conforme já apresentado as premissas para a inclusão social são: acesso ao emprego (digno), valorização profissional, solidariedade social, programas institucionais, educação profissional e continuada, segurança, justiça social, qualificação social, igualdade educacional e acesso a bens e serviços.

\footnotetext{
A Inclusão Social está relacionada com a procura de estabilidade social através da cidadania social, ou seja, todos os cidadãos têm os mesmos direitos na sociedade. A cidadania social preocupa-se com a implementação do bem-estar das pessoas como cidadãos. (SHEPPARD,2006,p.22)
}

Observa-se que a política pública de qualificação não conseguiu estabelecer um elo entre o capital e o social, vinculando suas metas e objetivos ao crescimento e aumento da competitividade do turismo em detrimento da emancipação do trabalhador, fator que deveria estar entre as prioridades das políticas públicas do setor que depende prioritariamente do trabalho humano.

O turismo está fortemente vinculado à inclusão social, ao se constituir de uma prática que vai além da área econômica, mas, sobretudo social, a qual possibilita a convivência e troca de experiências, acesso ao trabalho gratificante e digno, ao lazer e ao descanso, ao desenvolvimento social e, consequentemente dos territórios regionais, principal premissa trabalhada pela política de qualificação do MTur, mas que de forma isolada não passa de discurso.

A educação/qualificação/formação profissional apresenta-se como primazia frente à superação das desigualdades presentes nas relações sociais estabelecidas entre turistas, trabalhadores e empresários, como prioridade para atingir a igualdade social entre os pares.

Diante ao que foi estabelecido pela política de qualificação, entre os anos 2003-2015, as ações pautaram-se nas necessidades pontuais das empresas do setor, por meio de programas executados ao longo desse período, como: o Bem 
Receber Copa, Olá Turista, Caminhos do Sabor, PRODETUR, PRONATEC Turismo, entre outros. Estas ações arrolaram os trabalhadores como coadjuvantes desse processo, cabendo a estes receber as "capacitações/treinamento" e colocá-las em prática para encantar os turistas e atingir a excelência na prestação de serviços com padrão de qualidade internacional.

Esta visão coloca mais uma vez o trabalhador como um mero capital humano do sistema produtivo, pois se promovem qualificações/treinamentos específicos às ocupações do setor, com ênfase em competências técnicas e operacionais para garantir a eficiência na prestação de serviços, tendo como meta o aumento da produtividade, ou seja, aumentar a renda das empresas e o número de investimentos em decorrência da maior circulação de turistas.

Esses espectros são decorrência do capitalismo que promove e estimula a segmentação e a fragmentação (SARUP, 1978), que se solidifica na qualificação compartimentada e em série, na qual cada profissional se torna apto para realizar tarefas específicas sem ter capacidade de entender as dinâmicas do turismo e o seu contexto.

A práxis dessa política está centrada em uma relação de poder, na qual os benefícios são auferidos prioritariamente para os empresários do setor de turismo e hospitalidade, considerando que cabem apenas a estes as oportunidades de crescimento que possibilitarão alavancar o setor. Aos profissionais restam às arestas desse presumível desenvolvimento, por meio de um processo de educação profissional inadequado a uma formação integral, e, a promessa de inserção ou ascensão profissional. Se configurando na inversão de papeis quanto aos beneficiários por direito de uma política pública de qualificação profissional. Deste modo os profissionais não conseguem ser atendidos em sua totalidade por uma educação que Ihes oportunize a emancipação.

Constitui ferramenta da Educação Profissional a formação no local de trabalho que, frequentemente, ocorre na forma de adestramento, no qual é oferecido um aprendizado objetivo, mas, fracassado em relação à construção da autonomia, essa qualificação atua de forma imediatista não possibilitando uma formação para a emancipação dos sujeitos, por meio de um horizonte de orientação. (Adorno,1995). 
A relação de poder estabelecida nas políticas públicas coaduna com o entendimento de Arendt (2001) de que o espaço político como espaço de participação cidadã esvaziou-se, não se concretiza na prática, pois as políticas públicas são concebidas em estreita consonância com o mercado e com o crescimento econômico.

Corrobora com esse entendimento o que está contido no Relatório de Análise Documental (MOESCH, 2014) que o processo de qualificação foi fragmentado, composto de planejamento restrito e objetivos inconsistentes por parte do MTur e de seus parceiros, como as Secretarias de Turismo e as entidades do setor, expressos pela priorização das metas quantitativas em detrimento das qualitativas, ínfima presença de monitoramento, avaliação e indicadores de desempenho e a baixa qualidade pedagógica dos projetos.

Essa análise possibilitou uma crítica ao processo de implementação do programa de qualificação do MTur, salientando que houve pouca clareza quanto à definição dos papéis entre os atores sociais e o Ministério, causando dispersão de recursos e superposição de ações; concentração de ações em determinadas entidades; baixa integração dos programas de qualificação e demais programas de formação em cada território (Sistema S e Educação Formal); pouca ênfase na elevação da escolaridade; ausência de indicadores de avaliação externa; falta de monitoramento e revisão de ações de forma contínua; inexistência de uma perspectiva de educação continuada; baixa qualidade pedagógica dos cursos; ausência de conteúdos mínimos e de carga horária mínima, consequentemente baixa carga horária média dos cursos (formação vocacional) e valorização de pedagogia ativa em detrimento de uma pedagogia problematizadora. (MOESCH, 2014).

Outro fator relatado foi a desarticulação da Política de Qualificação do MTur com a Política Nacional de Qualificação do MTE e diálogo com o MEC ocorrendo esvaziamento do papel educativo e formativo dos programas propostos, pois muitos destes restringiram-se a uma preparação de um saber-fazer aos trabalhadores para o âmbito do paradigma fordista de qualificação, quando vive-se desafios bem mais complexos no campo do turismo e hospitalidade na atualidade. (MOESCH, 2014). 
Observa-se que o planejamento, constitui-se de fase prioritária que antecede as propostas de políticas públicas, deve visar algum tipo de sociedade "alternativa", na qual o princípio de igualdade na distribuição da riqueza e da renda tenda a ser maximizado. O planejamento social definido como um conjunto de técnicas, métodos e procedimentos para desenvolver a política social em termos de uma intervenção programada na sociedade. (BUSTELO, 1982).

Em que pese ter ocorrido um planejamento macro por parte do MTur e parceiros focado nas demandas apenas do setor, as questões relativas aos trabalhadores não foram adequadamente tratadas, estes ficaram a mercê do que Ihes era atribuído: cursos voltados para o desenvolvimento de habilidades técnica e operacionais. O que resultou em uma trajetória de qualificação que pouco avançou, especialmente, pela implementação do Programa Bem Receber Copa, em 22 de dezembro de 2010, implementado em parceria com entidades do setor, com objetivo de possibilitar atingimento de padrões internacionais de qualidade nos serviços turísticos, com foco em pessoas, empresas e destinos. Tendo como slogan "O Sucesso do Brasil na Copa está em nossas mãos". (PNT, 2013).

O programa foi planejado e implementado para diferentes segmentos: alimentação fora do lar, transportes aéreos regionais, locação de automóveis, hospedagem, turismo de aventura, operação de turismo, negócios e eventos. Tendo como objetivo qualificar, até 2013, por meio de soluções presenciais e a distância, 306 mil profissionais da linha de frente ao turista. Com parceria com a FGV Online para dar suporte à elaboração do planejamento pedagógico das instituições, avaliar os materiais didáticos por elas produzidos, acompanhar a oferta das soluções educacionais que constituem as trilhas de aprendizagem, verificar a eficácia do Programa.

Foi estruturado de forma descentralizada, com a participação das entidades do setor, responsáveis pela qualificação e treinamento do pessoal envolvido em cada segmento do turismo e hospitalidade, no entanto, essas não possuíam legitimidade e competência para planejar e executar ações de educação profissional. O que culminou em vários fracassos, sendo inclusive alvo de investigação da Policia Federal e do Ministério Público. Resultando na suspensão definitiva do Programa em 22 de setembro 2011 a pouco mais de dois anos do Megaevento. 
O ocorrido configura-se no distanciamento entre a teoria e a prática, uma vez que as entidades do setor possuíam legitimidade para participar do Programa, não como executor, mas como parceiros, por exemplo, no apoio a divulgação e acompanhamento, na intermediação de pessoal e na formatação de planos de reconhecimento e valorização profissional que complementassem o Programa, não possuindo expertise para a finalidade proposta de educação/ formação.

Esse evento exigiu uma nova postura por parte do MTur visando estabelecer novos paradigmas na qualificação do setor, tais como: elaborar documentos e portarias internas para respaldar a área de qualificação quanto execução de novas ações, responder as diligências dos órgãos de controle, elaborar prestações de contas dos convênios celebrados no âmbito do Bem Receber Copa, responder as diversas representações das entidades de classes em relação as solicitações de devolução total ou parcial dos recursos federais ${ }^{67} \mathrm{e}$, iminente planejamento para atender as necessidades de qualificação para os megaeventos.

Em que pese os desacertos e problemas oriundos, especialmente do programa destinado à preparação para a Copa do Mundo de Futebol FIFA 2014, houve acertos e ações bem-sucedidas como, por exemplo, o projeto Trilha Jovem que pretendia desenvolver e inserir jovens de famílias de baixa renda no setor do turismo. O objetivo geral desse projeto foi a formação profissional de jovens (entre 16 a 24 anos, estudantes ou egressos do ensino médio da rede pública, com renda familiar de, no máximo, 3 salários mínimos) nas áreas de alimentos e bebidas, meios de hospedagem e agências de viagens, para o desenvolvimento de competências básicas e inserção social e profissional no mercado de trabalho. (MOESCH, 2014).

A educação integrada e centrada no desenvolvimento de competências básicas para o turismo; protagonismo juvenil; currículo articulado por projetos (problemas e desafios); capacitação de mentores e uso intensivo da tecnologia da informação; efetivo encaminhamento ao mercado de trabalho (durante 6 meses após o término da etapa presencial); acompanhamento pedagógico durante as primeiras

\footnotetext{
${ }^{67}$ Processo muito complexo, uma vez que a equipe técnica do MTur precisa dar vasão as prestações contas, atender aos órgãos de controle e responder as representações das entidades do setor sem ter uma preparação adequada para tais funções que estão atreladas ao campo jurídico, entretanto a experiência vivida por esta pesquisadora indicou a inexistência de suporte adequado desta área.
} 
80 horas de atuação profissional foram diferenciais do projeto que se iniciou em Salvador em 2004 e foi expandido em 2008 para outras regiões. (BRASIL, 2014 cc).

Merece destaque também o Programa Aventura Segura, iniciado em 2006, que foi uma ação do MTur, em parceria com o SEBRAE e com a Associação Brasileira das Empresas de Turismo de Aventura e Ecoturismo (ABETA). Tornou-se uma iniciativa de organização e desenvolvimento dos segmentos de ecoturismo e aventura, por meio de ações de qualificação, certificação e estruturação da oferta de produtos desses segmentos. Além da elaboração de diversas normas técnicas para o ecoturismo e o turismo de aventura foram desenvolvidos manuais de boas práticas, conteúdos técnicos direcionados aos empresários e profissionais do segmento. (BRASIL, 2014cc).

Essas ações foram consideradas boas práticas, por oportunizar uma dinâmica mais completa em relação à qualificação, promovendo a inserção e acompanhamento de jovens no mundo do trabalho do setor, bem como a valorização das atividades de gestão e governança local e a disseminação de normas técnicas para o segmento de ecoturismo e turismo de aventura. Em que pese esses bons exemplos, à deficiência de acompanhamento e avaliação das ações ocasionaram diversos entraves no Programa do MTur o que acarretou a ruptura total com as antigas ações para o estabelecimento de um novo Programa de qualificação.

A busca pela reestruturação da política de qualificação culminou na adesão ao PRONATEC, programa do MEC instituído ao final de 2011 com objetivo de se concentrar as ações de qualificação e estimular o processo de formação da força de trabalho no país. O programa estabelece os ajustes educativos, tecnológicos e profissionalizantes que as políticas educacionais nacional e regional devem adotar, integrar e articular para atender aos requerimentos demandados pelos setores produtivos. Como objetivos principais, o PRONATEC institui:

I - expandir, interiorizar e democratizar a oferta de cursos de educação profissional técnica de nível médio presencial e a distância e de cursos e programas de formação inicial e continuada ou qualificação profissional; II - fomentar e apoiar a expansão da rede física de atendimento da educação profissional e tecnológica; 
III - contribuir para a melhoria da qualidade do ensino médio público, por meio da articulação com a educação profissional;

IV - ampliar as oportunidades educacionais dos trabalhadores, por meio do incremento da formação e qualificação profissional;

$\mathrm{V}$ - estimular a difusão de recursos pedagógicos para apoiar a oferta de cursos de educação profissional e tecnológica.

VI - estimular a articulação entre a política de educação profissional e tecnológica e as políticas de geração de trabalho, emprego e renda. (Incluído pela Lei no 12.816, de 2013). (BRASIL. Lei no 12.513, 2011d).

Fora vislumbrado pelo MTur a oportunidade de se estabelecer uma estreita parceira com o MEC e o MTE de forma a promover uma articulação entre educação profissional para o setor de turismo e hospitalidade e a alocação profissional o que poderia contribuir para um desenvolvimento mais efetivo do setor.

O planejamento advindo com a adesão ao PRONATEC, conforme já mencionado, ocorreu em um momento complicado para o Ministério, no qual houve diversas trocas de ministro ${ }^{68}$, mudanças na Diretoria do Departamento de qualificação, particularmente toda a equipe foi substituída por servidores ${ }^{69}$ novos ou de outros departamentos, falta de registro conciso das ações anteriormente planejadas e executadas, ocasionando um processo de (des)construção para (re)construir.

O histórico da Política pública de qualificação profissional do país aponta os equívocos que marcaram essa trajetória, como: a visão estreita sobre o Turismo, pautando-o apenas na esfera econômica, que considera o desenvolvimento humano uma extensão simplista desse processo, por meio da geração de emprego e renda. Concepção que coloca a qualificação como uma ação pontual e isolada, uma vez que essa política não conseguiu avançar para consolidar empregos dignos no setor.

A educação profissional é um pilar para consolidar o crescimento, à medida que potencializa 0 treinamento padronizado e conhecimentos fragmentados, distantes da emancipação dos sujeitos, pelo contrário, propulsores de limitações; e, a ausência de planejamento efetivo, com objetivos e metas claras, que priorizem a formação integral dos sujeitos (trabalhadores do setor). Conforme aponta Moesch

\footnotetext{
${ }^{68}$ Ministro Gastão Vieira (14/09/2011 a 17/03/2014)

Ministro Vinicius Lages (17/03/2014 a 16/04/2015)

Ministro Henrique Eduardo Alves (16/04/2015 a 16/06/2016)

${ }^{69} \mathrm{~A}$ maior parte dos técnicos do antigo Departamento de qualificação eram servidores recémempossados no serviço público, com nenhuma experiência em políticas públicas de educação profissional e/ou no tema.
} 
(2015) o Turismo se realiza por meio das relações humanas, essas interações promovem as experiências turísticas, o que torna essencial colocar os sujeitos em primeiro lugar em detrimento dos interesses econômicos e do mercado. A política pública de turismo não conseguiu pautar em suas prioridades os sujeitos, que são essenciais para o efetivo desenvolvimento do setor. 


\section{EVIDÊNCIAS FINAIS}

A educação profissional no Brasil foi concebida primordialmente para atender ao capital e ao interesse das classes dominantes que entendem os trabalhadores como possível "mão-de-obra preparada e capacitada para agregar valor ao mercado" (aumento de produção, geração de lucros e mais valia para a empresa). No ciclo capital-trabalho o trabalhador tem um papel de mero coadjuvante à medida que trabalha para suprir suas necessidades básicas como: moradia, saúde, alimentação, vestiário, assistência médica, educação e lazer ${ }^{70}$. Este contexto limita o trabalho como fardo que precisa ser cumprido para 0 atendimento das necessidades humanas básicas.

Conforme descreve Krippendorf (2001 p. 83) "a liberdade e o prazer de um são o fardo e o trabalho do outro". Isso representa parte do ciclo que ocorre no Turismo, no qual as necessidades do turista (ambiente de férias) se choca com as necessidades de repouso e de existência do outro (trabalhador).

Vive-se uma crise no mundo do trabalho, derivada não apenas da situação econômica global, mas, sobretudo do embate que ocorre em relação ao atendimento das demandas do capital (aumentar a produção, a competitividade e acompanhar as novas tecnologias) e os anseios da classe trabalhadora por uma humanização do trabalho.

O modelo de educação profissional adotado no País, não vem atendendo aos anseios por uma construção emancipatória, ao contrário, ele mantém a situação estabelecida pelo capital, de ser um insumo (in put) para maior produtividade e lucro (out put).

A definição de ensino pré-vocacional e profissional contida na Constituição Brasileira de 1937 em seu artigo 129 coaduna com a ideia da educação profissional para a produção:

O ensino pré-vocacional e profissional destinado às classes menos favorecidas é, em matéria de educação, o primeiro dever do Estado. Cumpre-lhe dar execução a esse dever, fundando institutos de ensino profissional e subsidiando os de iniciativa dos Estados, dos Municípios e

\footnotetext{
${ }^{70}$ Grifo nosso: trata-se de necessidades básicas, entretanto, relegadas a segundo plano, pois, o trabalho nessas circunstâncias consome muito tempo das pessoas, não sobrando espaço nem dinheiro para investir em educação e no lazer.
} 
dos indivíduos ou associações particulares e profissionais. É dever das indústrias e dos sindicatos econômicos criar, na esfera de sua especialidade, escolas de aprendizes, destinadas aos filhos de seus operários ou de seus associados. A lei regulará o cumprimento desse dever e os poderes que caberão ao Estado sobre essas escolas, bem como os auxílios, facilidades e subsídios a lhes serem concedidos pelo poder público". (BRASIL, 1937z).

Ideia que ainda se faz presente na atualidade, pois verifica-se que a educação profissional foi planejada para prover o País de "mão de obra produtiva" (ensino operacional) e aperfeiçoar os trabalhadores (ensino vocacional), visando o crescimento do mercado, galgando à utilização do pensamento crítico a classe dominante, enquanto que a classe desvalida cabe apenas um aprendizado repetitivo, mecânico para "aperfeiçoar" sua força de trabalho. Processo educacional histórico que reproduz a contradição existente entre as forças produtivas e as relações de produção, entre as classes exploradoras e exploradas. (GADOTTI, 1983).

É inaceitável a predominância e continuidade, por parte de uma política pública, do ensino fragmentado, especializado, baseado no desenvolvimento de competências e conhecimentos para postos de trabalho privativos, sem que haja um contraponto para a educação emancipatória dos sujeitos e, que o turismo reproduza essa prática de treinamento compartimentado, qualificando para postos trabalhos específicos, sem se preocupar com a efetiva inserção profissional, inclusão social e desenvolvimento humano.

A LDB em seu artigo 39 aponta que a formação profissional, no País, ocorre em escolas de Educação Profissional, públicas e privadas, que ofertam cursos de formação inicial e continuada, cursos técnicos e tecnológicos, destinados a atender pessoas desempregadas e/ou que busquem uma formação/qualificação para seu aperfeiçoamento profissional. Neste contexto, essas escolas, possuem a responsabilidade de gerar saberes coletivos e flexíveis, sintonizados com as novas bases e novas formas de organização produtiva ${ }^{71}$, fundados na produção e difusão de inovações de cunho tecnológico, marca fortemente presente nos últimos séculos. (BRASIL, 1996b).

${ }^{71}$ Grifo nosso. 
Ao buscar verificar se o PRONATEC Turismo possibilitou a construção de carreiras profissionais aos seus egressos no setor de Turismo e Hospitalidade, se evidenciou as tramas sociais que envolveram o caminho trilhado pela implantação dessa política pública de qualificação. Demonstrando os limites da execução do Programa, à medida que contradições foram sinalizadas tanto na análise documental como na análise de conteúdo investigadas pelos achados desta investigação. Ambas quando cruzadas confirmam a fragmentação que envolveu a politica de qualificação profissional entre os anos de 2004-2015.

É possível inferir que a prioridade do Programa (MEC) foram os cursos de formação inicial em detrimento dos cursos técnicos e tecnológicos (esses dois últimos apresentam-se como oportunidade mais relevante para a construção de carreiras, inclusão social e desenvolvimento humano) ao se constatar que maior parte dos recursos do PRONATEC foram investidos na oferta de cursos FIC (5,8 milhões pelo Programa no período de 2011 a 2015), considerando todos os eixos tecnológicos ${ }^{72}$.

Essa percepção também prevaleceu ao analisarmos a oferta de cursos do PRONATEC Turismo (apenas cursos FIC) e alguns planos de cursos, conforme já demonstrado, os quais em sua maioria trabalharam com conteúdos destinados a aquisição de saberes restrito a uma ocupação o que limitou a prerrogativa de construção de carreiras em Turismo e Hospitalidade.

Infere-se que a política pública de educação profissional, mais uma vez, se restringe ao pensando pontual: desenvolver competências precisas para uma conjuntura específica sem se preocupar com a dinâmica que envolve o mundo do trabalho. Essa evidência apareceu na fala de alguns gestores e professores do Programa: "poder público muito assistencialista e sem resultado algum. O papel do poder público não é preventivo e tenta ser corretivo" (Gestor a).

"Não percebi preocupação do poder público na realização desses cursos, pois a forma como se dava o PRONATEC era como querer "tapar o sol com a peneira" porque julga não ser possível realizar uma capacitação continuada com cursos de curta duração". Os cursos de curta duração seriam apenas uma das

\footnotetext{
${ }^{72}$ Não foi possível verificar deste montante quanto foi investido no Eixo Turismo, hospitalidade e
} lazer. 
etapas de formação para o aluno "[...] não se enfatizava a questão da qualidade em sua execução". (professor b).

Percebe-se que ao planejar o PRONATEC o MTur não priorizou a elevação da escolaridade, pela educação continuada; a valorização e reconhecimento profissional e a construção de carreiras. De modo a permitir aos sujeitos descobrir o trabalho no Turismo e Hospitalidade como oportunidade interessante, gratificante e criativa, no qual possam desenvolver-se permanentemente pelas relações de troca e aprendizado e pela formação ativa, crítica, consciente e participativa.

A contradição/fragmentação encontradas na análise de conteúdo e documental permitiu apurar casos de boas práticas obtidos pela implantação dos cursos de educação profissional, PRONATEC Turismo, sobretudo resultado da ação e vontade de cada sujeito, egressos e professores envolvidos no processo, que de um modo ou de outro se mostraram mais atuantes, conforme relatos, em que conteúdos foram adaptados a realidade local, a concepção ideológica da educação como meio de formar cidadãos, e ampliação da cidadania pelo empoderamento e participação ativa junto à comunidade.

Que sejam estimulados a pensar criticamente, a buscar mudar o que não
consideram estar bom, ser mais ativo socialmente. Inserir nos cursos de
qualificação em turismo disciplinas voltadas a formação cidadã, ao papel do
ser social na busca da melhoria do lugar, a importância da atividade para a
sociedade etc. é um caminho. (professor d).

Percebeu-se ainda uma notória valorização por parte dos egressos quanto aos cursos capitaneados pelas instituições públicas de ensino superior, haja vista que muitos indivíduos de baixa renda e escolaridade não vislumbravam o acesso a essas instituições tão próximas a eles, oque só foi possível pela oferta do PRONATEC.

Nos relatos obtidos na pesquisa de campo com os atores locais que participaram desse processo, gestores públicos, professores e egressos, verificou-se que alguns cursos ofertados possibilitaram desenvolver a autoestima e o desenvolvimento pessoal dos alunos participantes. Esse auto reconhecimento como sujeitos permitiu o empoderamento e, consequentemente, a mudança na trajetória de vida. 
Um despertar para a continuidade dos estudos pela educação formal, como perspectiva de trabalho e carreira no setor, a compreensão de direitos e deveres de cidadão, o conhecimento sobre as potencialidades do turismo na sua região, bem como o interesse pelos problemas da localidade foram construções que se elaboraram no itinerário formativo dos egressos.

Em que pese essas boas práticas, a efetiva construção de carreiras permaneceu distante de ser alcançada, pois mais uma vez a política proposta buscou atender uma conjuntura dada demandas do mercado para a Copa do mundo de Futebol FIFA 2014.

Ao analisar se a formação profissional do PRONATEC Turismo foi possibilitadora do desenvolvimento humano dos seus egressos e consequente inclusão social, observa-se a mediação ocorrida nesse aspecto, ou seja, o atingimento de um resultado relativo dessa ação. Pois ficou perceptível a importância dada à disponibilização dos cursos como uma ação em prol do desenvolvimento humano e inclusão social, na medida em que oportunizou acesso aos cursos a uma parcela da sociedade, mas devido a sua descontinuidade como ação de educação permanente, apenas os egressos que por condicionantes particulares (itinerário educacional e condições econômicas) ingressaram no ensino médio ou tecnológico. Observa-se a totalidade/fragmentação do processo de implementação do Programa, pois não se pode negar que para alguns o desenvolvimento humano e a inclusão social pela educação/formação ocorreu como "passar no vestibular", "traz uma perspectiva de crescimento pessoal", e tem um grande valor simbólico pois demonstrou a muitos adultos que era possível recuperar sua trajetória individual, marcada pelo fracasso escolar, em um novo patamar de inclusão no mundo do conhecimento, o qual estava distante desde sua adolescência ou infância, pois "foi motivador para buscar outros níveis de escolaridade"..

Para essas pessoas o curso proporcionou uma mudança que pode ampliar o seu desenvolvimento e a inclusão social, apesar de não ter se configurado o acesso ao emprego.

Entretanto para além do acesso a educação profissional e ao emprego são necessárias outras ações para se atingir a totalidade do processo de formação, uma vez que o desenvolvimento humano está intimamente ligado com a satisfação das 
necessidades dos sujeitos (fisiológicas, de segurança, amor/relacionamentos, estima e relação pessoal) que não estão relacionados apenas com a educação/emprego. É um processo que possibilita ampliar o rol de escolhas das pessoas, estando intimamente relacionado ao trabalho (digno), proporcionado uma relação recíproca e a inclusão social.

O PNUD (2015), fomentador de muitas ações do Ministério do Turismo apresenta 0 círculo positivo que 0 trabalho pode proporcionar para 0 desenvolvimento humano (figura 14):

Figura 14 - Sinergias entre trabalho e desenvolvimento

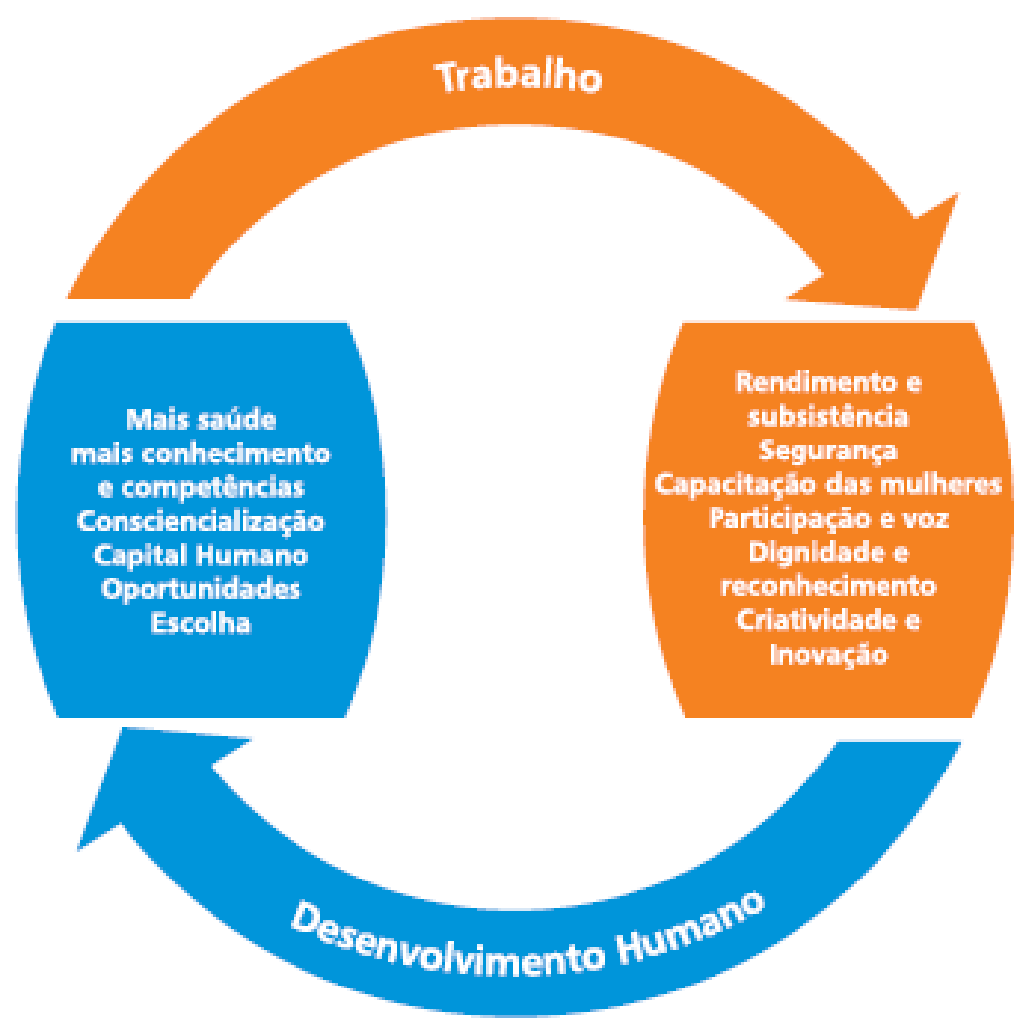

Fonte: PNUD, 2015

Nessa dinâmica o trabalho possibilita atender para além das necessidades básicas dos sujeitos, podendo promover a segurança para construção de uma base que lhes permita tomar decisões a longo prazo e definir prioridades e escolhas, 
proporcionando maior interação e participação na tomada de decisões em sociedade. Fato que pode ser potencializado pelo Turismo, desde que o trabalho esteja atrelado ao processo virtuoso de formação profissional, o qual permitirá desenvolver a criticidade, o interesse e a participação na resolução dos problemas inerentes ao Turismo e a Hospitalidade, e, a sociedade. O reconhecimento do bom desempenho profissional proporciona ao trabalhador um sentimento de realização, de autoestima e de identidade social, enquanto a criatividade e a inovação revolucionam múltiplos aspetos da vida humana (como a saúde, a educação, a comunicação e a sustentabilidade ambiental).

Os trabalhadores de Turismo e Hospitalidade podem beneficiar-se desta dinâmica à medida que a área tem enorme potencial para a aquisição de conhecimentos e competências que Ihes permitam avançar em direção ao desenvolvimento humanizador. Permite adquirir maior consciência para participar de forma plena em sociedade. "A satisfação e a felicidade dos trabalhadores são elementos essenciais para reforçar os laços entre o trabalho e o desenvolvimento humano". (PNUD, 2015, p. 53).

Sachs (1998) aponta que o desenvolvimento pode ser redefinido em termos da universalização e do exercício efetivo de todos os direitos humanos: políticos, civis, e cívicos; econômicos, sociais e culturais; bem como direitos coletivos ao desenvolvimento, ao ambiente. Destaca especialmente o direto ao trabalho por possuir um valor duplo, intrínseco, mas também instrumental, já que o trabalho decente abre caminho para o exercício de vários outros direitos.

O processo de cidadania, atrelado diretamente ao desenvolvimento humano, deve ser recuperado pela educação. Nota-se que a educação profissional não vem correspondendo adequadamente a essa necessidade vital na formação dos trabalhadores, visando prepará-los para uma vida ativa em sociedade, por meio do trabalho, das realizações pessoais e da participação em sociedade e reivindicações de seus direitos. (FAVERO; CASAGRANDA org., 2012). Ao se estabelecer uma educação/formação profissional sob esse preceito os sujeitos estarão mais bem preparados para colocar em prática conhecimentos, habilidades e atitudes, não só em prol do trabalho, mas, também para a criação e participação cidadã. 
Corrobora como essa percepção o que se verificou em campo: "minha cidadania não são plenamente exercida"; "a minha condição de cidadania é ruim"; "condição de cidadania é regular".

Visando identificar a correlação entre as tipologias de cursos ofertados pelo PRONATEC Turismo às necessidades de demanda de trabalhadores das cidades sedes, a pesquisa identificou uma política de qualificação articulada aos interesses do mercado, para atenuar problemas específicos e não de modo integrado para a inclusão social e o desenvolvimento humanizador.

As aprendizagens estão ancoradas em fórmulas e repetições, rotinas e padrões pré-estabelecidas, com pouquíssimo espaço para a criatividade e a autonomia dos trabalhadores: "Todos os cursos ofertados são realizados com base na demanda de formação profissional do mercado de trabalho"; "[...] deu uma base de como é que funciona essa área de eventos"; "a duração do curso foi insuficiente para atender as necessidades do educando, precisaria ter uma ambientação, nivelamento para depois entrar nos conteúdos básicos e específicos"; "não da total segurança. Porque alguns assuntos eu não tenho domínio".

Assim responde-se a premissa levantada, quanto ao atendimento das necessidades dos trabalhadores que se sequer foi pontuada pela política de qualificação, a qual ficou restrita aos interesses dos empresários, demonstrando a falta de um diagnóstico territorial crítico, que apontasse o sistema local produtivo e suas necessidades de qualificação, a exemplo, microempresários na área de hospedagem, empreendedores individuais, produtores informais na área da gastronomia, trabalhadoras mulheres, produtores rurais, artesãos, entre outros.

Buscando desvelar se as ações de qualificação pelo PRONATEC Turismo induziram o aumento de empregabilidade de jovens e adultos nos anos 2014-2015 no setor de Turismo e Hospitalidade, objetivo do Programa, verificadas na análise das entrevistas com os egressos dos cursos, nas quais se infere que o ciclo virtuoso para inclusão social, construção de carreiras, reconhecimento, foi pouquíssimo alcançado, verifica-se na análise documental, que aproximadamente $53 \%$ dos egressos do PRONATEC Turismo não conseguiram ser inseridos no mercado de trabalho ou em atividades econômicas do setor. Resultado insatisfatório relacionado 
à empregabilidade desses egressos, na medida que apenas 10\% conseguiram colocação no setor de Turismo e Hospitalidade.

A ideia de que a qualificação profissional é propulsora de empregabilidade, se faz presente nos discursos do governo, no entanto se limita ao atendimento das necessidades do mercado cada vez mais competitivo e excludente.

Identifica-se nesses discursos a aproximação da teoria com a prática ao se conferir que um dos objetivos da política pública de educação profissional é a preparação dos sujeitos, especialmente de grupos menos favorecidos, para o mercado de trabalho (qualificação para a empregabilidade), na qual o treinamento prático é muito valorizado, entretanto essa premissa foi pouquíssima atingida.

Infere-se que a empregabilidade no período dos megaeventos esportivos e a inclusão social de jovens e adultos, egressos do PRONATEC Turismo, nas cidades sedes ficaram comprometidas pela falta de articulação entre a politica de qualificação e o sistema nacional de empregos (SINE) e o papel do governo (MTur, MEC, MTE) em articular a relação demanda-oferta. Não ocorreu essa ação de planejamento estratégico ocasionando superposição de ações entre esferas municipais, estaduais, ou ausência de qualquer articulação para pesquisar a demanda do território, organizar a oferta necessária e garantir por mecanismos reguladores e "premiadores" aos empresários a contratação destes jovens e adultos egressos dos cursos.

$\mathrm{Na}$ contramão deste contexto desarticulado em que ocorreu a implantação do programa houve casos de inclusão social por meio da inserção profissional no mundo de trabalho com $6^{73}$ (seis) egressos que conseguiram emprego após o término do curso, o que correspondeu a $20 \%$ dos entrevistados pela pesquisa de campo e, em torno de 10\% (dez por cento) de acordo com a minuta do Relatório de avaliação de resultados - PRONATEC Turismo (2012-2014).

Quanto identificar a relação do Programa PRONATEC Turismo, no período de 2012-2015, em relação às Atividades Características do Turismo (ACTs) e cursos de profissionalização correlatos, nota-se que, na maioria dos casos, isso ocorreu. Entretanto a premissa que apontou como consequência a estruturação de carreiras

\footnotetext{
${ }^{73}$ De um total de 30 entrevistas.
} 
não foi viabilizada adequadamente, porque não bastam que os cursos estejam de acordo com as ACT's ${ }^{74}$ para que se efetivem carreiras no Turismo e Hospitalidade. Em primeiro lugar é necessário estruturá-las, a começar por planos de carreiras e ascensão profissional, programas de educação continuada articulada ao ensino básico, tecnológico e superior, e, planos de inserção profissional no mundo do trabalho de Turismo e Hospitalidade articulados pelo sistema nacional de emprego, MTur e MEC.

A problematização desta pesquisa imputa responder se o Programa de Qualificação Profissional PRONATEC Turismo foi possibilitador da inclusão social de seus egressos no setor de turismo e hospitalidade.

Tem-se que o procedimento de elaboração/implementação da política de qualificação profissional acompanhou as subjetividades inerentes à política pública do Turismo, advindo de um processo fragmentado, no qual os interesses dominantes estavam voltados a atender as demandas das empresas do setor. As ações pautaram-se em demandas empresariais locais e parciais, com vistas a aumentar a competitividade e a visibilidade internacional do turismo nacional. Os resultados dessas ações foram poucos perceptíveis pela sociedade, já que não deixou um legado econômico (aumento do emprego e renda), conforme previsto, tampouco social (inclusão social).

Partindo da concepção de que inclusão social diz respeito à igualdade educacional, à valorização e reconhecimento dos sujeitos, acesso à formação e qualificação profissional, à segurança, aos bens e serviços, ao lazer e ao trabalho digno, essa premissa não foi adequadamente atingida tendo como referência a análise dos discursos dos sujeitos entrevistados e os dados dos relatórios do programa.

A inclusão dos sujeitos é determinante para uma vida ativa e o equilíbrio das oportunidades em sociedade, considerando que essa inclusão prioritariamente começa pelo acesso ao emprego qualificante, possibilitador do crescimento profissional, espaço onde o trabalhador possa criar, desenvolver-se e ter suas individualidades respeitadas. Acesso aos direitos sociais, políticos, civis,

\footnotetext{
${ }^{74}$ As ACT's se apresentam desatualizadas diante da dinâmica do turismo e hospitalidade, mas ainda assim são as vigentes e orientam as ações do MTE e MTur
} 
econômicos, culturais e ao lazer (CASALI, 2007; PNUD, 2015), premissas pouco perceptíveis.

No entanto, ao apontar as contradições do PRONATEC Turismo verifica-se, por ser mais uma ação de qualificação pontual, tendo como prioridade atender demandas urgentes de uma conjuntura dada, que o programa carregou possibilidades de inclusão social de alguns sujeitos por meio da "entrada" ao mundo formal da educação e alguns casos acesso ao emprego, sendo oportunidade única de vislumbrar este caminho para sua inclusão social

Infere-se que a política de qualificação do MTur alienou-se passivamente na corrente dominante contribuindo para manter a situação estabelecida, reprodução do passado (MOESCH, 1999), priorizando os interesses do mercado. Não se mostrou preocupada em cumprir todas as etapas, do planejamento a implementação, acompanhamento e avaliação consistente de seus resultados, assim a execução não conseguiu superar a ideologia dominante.

Os aspectos relativos à inclusão social, educação integral dos trabalhadores, geração de emprego e renda, também ficaram relegados a segundo plano, ao passo em que os trabalhadores do turismo e hospitalidade, não foram sequer mencionados nessa política, sendo tratados como meros coadjuvantes do processo.

A concepção equivocada do Turismo, adotada pelo MTur, não permitiu um planejamento adequado das ações de qualificação, limitando um entendimento de que esse processo por si só poderia garantir o desenvolvimento do setor. Não abrangendo a percepção de que os serviços turísticos são assegurados pelos moradores locais, uma parcela da comunidade que trabalha no setor, que junto aos empregadores fornecem uma contribuição essencial à vida turística, entretanto não se pode entender os recursos sociais, culturais e naturais de uma localidade como mercadorias, e sim como relações humanas. (MOESCH, 2015).

Pelo exposto nota-se que a educação profissional no País pouco avançou nos últimos 10 (dez) anos a visão predominante ainda é atender as demandas de um mercado explorador do trabalho e com salários e cargos pouco dignificantes, na qual coloca a responsabilidade da empregabilidade nas mãos dos trabalhadores (meritocracia). Treinar habilidades e competências é uma forma reducionista de 
qualificação profissional que por si só não induz a empregabilidade e a inclusão social.

Para que os trabalhadores do Turismo e Hospitalidade possam atingir esse patamar é preciso repensar as políticas públicas de educação profissional de modo que estas possibilitem uma formação integral, de qualidade, com propósitos claros para a elevação da escolaridade e continuidade do ensino.

Chama muita atenção, também, (APÊNDICE C) o nível de escolaridade dos egressos: em torno de $30 \%$ (trinta por cento) têm ensino superior incompleto, enquanto que aproximadamente $25 \%$ (vinte e cinco por cento) superior completo, fato evidenciado pelas categorias dialéticas da práxis, da historicidade, objetividade/subjetividade, autonomia/dependência, mostram que há toda uma conjuntura por traz da educação e do mundo do trabalho no Brasil, que dificulta a absorção desses egressos, quer seja, pela baixa qualidade da educação superior em turismo e hospitalidade e/ou outros áreas de formação (parte desses egressos eram oriundos de outras áreas), baixos salários pagos pelo setor, desvalorização profissional, a sazonalidade que acaba por evidenciar os empregos informais e temporários, o alto índice de desemprego que afeta todos os setores e, ainda, a inadequação da educação em todos os níveis para acompanhar as mudanças sociais.

Apresenta-se a educação profissional um desafio: tornar-se ferramenta capaz de desenvolver pessoas e suas potencialidades a fim de que elas possam avançar rumo à autonomia para minimizar a dependência do sistema econômico e suas crises.

Considerando a educação emancipatória como condição à inclusão social, ao desenvolvimento humano e à cidadania, trata-se da possibilidade de um ensino crítico, criativo e comprometido com as mudanças sociais, empenhado com 0 desenvolvimento total dos sujeitos, com uma sociedade justa e igualitária, proporcionando condições de desenvolvimento iguais a todos. (FREIRE, 1977, 1996).

Para construir a autonomia a educação precisa mais do que atitudes isoladas e ações esporádicas, é necessário levar em consideração o âmbito em que as ações educativas se desenvolvem, os sujeitos e seus itinerários educativos, e a coerência 
pedagógica para um ensino direcionado a jovens e adultos alijados historicamente do sistema formal educacional para que as politicas gerem resultados efetivos e significativos na vida das pessoas.

Entende-se que a educação emancipatória e cidadã é indispensável ao desenvolvimento humano, condição primordial para a cidadania e para criar condições de inclusão social permanente. Desse modo se fomenta um ciclo virtuoso no Turismo, por meio da geração de empregos qualificados ou trabalho autônomo/heterônomo e maior participação na sociedade. É preciso compreender de uma vez por todas que o desenvolvimento do turismo não depende apenas do crescimento econômico e do aumento da competitividade dos destinos, mas sim das pessoas que trabalham com ou no turismo.

A mentalidade estreita e reducionista sobre as possibilidades do Turismo como prática social e histórica, só se muda pela educação e pela construção de um novo Turismo. Para tanto a educação profissional deve ter como objetivo principal preparar os sujeitos para a construção (re)reconstrução permanente do conhecimento, buscando acompanhar a dinâmica do setor e da vida em sociedade.

A partir da aplicação das categorias operatórias da dialética, percebidas nos discursos dos sujeitos, foi consolidada uma análise com base em informações contidas nos relatórios regionais da Pesquisa Avaliativa dos Arranjos Territoriais Possibilitadores da Qualificação em Turismo (MOECH, 2016), evidenciando que:

$\checkmark$ o Programa foi uma oportunidade para pessoas em condições de risco, vulnerabilidade social, desempregadas, ou que ainda sofriam maus tratos em casa para um despertar de novas possibilidades em suas vidas relacionadas ao Turismo e Hospitalidade, o que não era percebido como algo a ser atingido por esses cidadãos;

$\checkmark$ houve uma notória valorização da população quanto aos cursos capitaneados pelas instituições públicas de ensino superior, haja vista que muitos indivíduos de baixa renda e com baixa escolaridade não vislumbravam o acesso a essas instituições tão próximas a eles;

$\checkmark$ em alguns cursos ofertados houve a possibilidade de desenvolver a autoestima e o desenvolvimento pessoal em muitos sujeitos. Esse auto 
reconhecimento como sujeitos permitiu seu empoderamento e, consequentemente, a mudança na trajetória de vida;

$\checkmark$ ocorreu um despertar para a continuidade dos estudos pela educação formal, como perspectiva de trabalho e carreira no setor, a compreensão de direitos e deveres de cidadão, o conhecimento sobre as potencialidades do turismo na sua região, bem como o interesse pelos problemas da localidade foram construções que se elaboraram no itinerário formativo dos egressos.

As contradições estudadas pela implantação do PRONATEC Turismo são correlatos aos problemas constatados, atualmente, em relação à educação no Brasil (discutível qualidade do ensino básico e técnico, baixa remuneração dos professores, entre tantos outros). Estes fatores implicam na fragilidade da política pública de educação profissional, que não consegue avançar enquanto política social para possibilitar a geração de emprego e renda, a inclusão social e o desenvolvimento humano, já que há uma gama de profissionais com nível superior desempregados, que, não estão conseguindo se inserirem no mundo do trabalho e buscam na educação profissional uma forma de se tornarem competitivos no mercado, sem se quer falar de tantos outros desempregados em situação de vulnerabilidade social com baixíssimo nível de educação básica que não tem suas necessidades básicas atendidas, e permanecem na berlinda do sistema capitalista.

A política de educação profissional não consegue transpor esse mundo de aparências para se consolidar enquanto ação efetiva para o desenvolvimento humano e inclusão social. Veste-se com uma roupagem de ilusão e esperança, uma "pseudoconcreticidade" 75 salvadora da situação de pobreza, estruturada em ações de meritocracia em um país de históricas e cruéis diferenças de acesso a uma vida digna.

\footnotetext{
${ }^{75}$ Partindo do princípio de que há uma diversidade de questões para além das formas aparentes, que Kosik (1976) chama de pseudoconcreticidade, o ponto a ser observado e compreendido para se começar a empreender uma ultrapassagem rumo à realidade concreta-pensada do espaço é justamente aquele concernente às interações e divisões estabelecidas entre os sujeitos ao levarem a cabo sua produção material e imaterial (KOSIK,1976 apud MARTONI, 2014)
} 


\section{POSFÁCIO}

A história representa o movimento, a ação criativa, a invenção constante de novos lances, mesmo que seus sujeitos estejam limitados por regras e normas. A história é possível porque os homens, mesmo limitados por um dado contexto, por um conjunto de regras e prescrições, ainda que atuando em um espaço e em um tempo delimitados, são capazes de driblar a potência do mesmo e a imposição da repetição e criarem o diferente, a novidade, de produzirem a surpresa e o inesperado. A história, como um jogo, faz-se de risco e habilidade, de variação e mudança, de limite e invenção, de regras imanentes e de restrições voluntárias. (FOUCAULT,1984). 


\section{REFERÊNCIAS}

ADORNO, T. Educação e Emancipação. Rio de janeiro: Paz e Terra, 1995.

AGUILAR, M. J. ; ANDER-EGG E. Avaliação de serviços e programas sociais. Petrópolis: Ed. Vozes, 1994.

ALVES, E.; VIEIRA, C. Qualificação Profissional: Uma proposta de Política Pública In: Revista Planejamento e políticas públicas no 12 - jun/dez de 1995. p. 30.

BARDIN, L. Análise de conteúdo. São Paulo: Edições 70, 2011.

BORBA, A. ; LIMA, H. Exclusão e inclusão social nas sociedades modernas: um olhar sobre a situação de Portugal na União Europeia. Revista Serviço Social e Sociedade. São Paulo, n. 106, p. 219-240, abr./jun. 2011.

BRUYNE, Paul. Dinâmica da pesquisa nas ciências sociais: os polos das práticas metodológicas. Rio de Janeiro: Francisco Alves, 1977.

BRASIL. Lei no 9.394, de 20 de dezembro de 1996. Estabelece as Diretrizes e Bases para Educação Nacional. Diário Oficial da União. Brasília. 20 dez. 1996b.

BRASIL. Ministério da Educação. Políticas Públicas para Educação Profissional e Tecnológica (EPT) no Brasil. Brasília. SETEC, 2015.

BRASIL. Ministério da Educação. Centenário da Rede Federal de Educação Profissional e Tecnológica. Brasília: $2009 f$.

BRASIL. Ministério da Educação. Lei n. 12.513, de 26 de outubro de 2011. Institui - Programa Nacional de Acesso ao Ensino Técnico e Emprego (PRONATEC). Diário Oficial da União, Brasília: 27 out. 2011d.

BRASIL. Lei n. 13.005, de 25 de junho de 2014. Aprova o Plano Nacional de Educação (PNE). Diário Oficial da União, Brasília, DF, 26 jun. 2014i.

BRASIL. Ministério da Educação. Programa Nacional de Acesso ao Ensino Técnico e Emprego (PRONATEC). Guia PRONATEC de cursos FIC. Brasília: MEC; SETEC; PDE, 2012h.

BRASIL. Ministério da Educação. Diretoria de Políticas de Educação Profissional e Tecnológica. Catálogo Nacional dos Cursos Técnicos - Edição 2015. Brasília: MEC; SETEC, 2015.

BRASIL. Ministério da Educação. Educação Profissional e Tecnológica. Legislação Básica - Nível Superior. Brasília, 2008: $7^{a ̣}$ edição. 
BRASIL. Ministério da Educação. Pronatec 2016. Disponível em http://portal.mec.gov.br/pronatec/pronatec-2016. Acessado em 10 set. 2016h.

BRASIL. Lei $n^{0} 11.171,2008$. Dispõe sobre a Política Nacional de Turismo. MTur: Brasília, 2008I.

BRASIL. Ministério do Turismo. Plano Nacional do Turismo: diretrizes, metas e programas 2003-2007. Brasília: MTur, 2003c. 48 p.

BRASIL. Ministério do Turismo. Plano Nacional do Turismo: uma viagem de inclusão 2007- 2010. Brasília: MTur, 2007b. 88 p.

BRASIL. Ministério do Turismo. Plano Nacional do Turismo: o turismo fazendo muito mais pelo Brasil 2013-2016. Brasília: MTur, 2013z. 116 p.

BRASIL. Ministério do Turismo. Diretrizes Nacionais de Qualificação em turismo. Brasília: MTur, 2015a.

BRASIL. Ministério do Turismo. Programa Nacional de Qualificação Profissional e Empresarial do Turismo. Brasília: MTur, 2006q.

BRASIL. Ministério do Turismo. Suspende, temporariamente, a execução e o repasse de recursos de todos os convênios e instrumentos congêneres celebrados com entidades privadas sem fins lucrativos, destinados à qualificação dos profissionais do setor do turismo, em especial aqueles firmados no âmbito do Programa Bem Receber Copa. Portaria, no 180 de 22 de setembro de 2011. Brasília, MTur, 2011s.

BRASIL. Ministério do Turismo. Estabelece regras e critérios de execução e monitoramento do Programa Nacional de Acesso ao Ensino Técnico e Emprego, no âmbito do Ministério do Turismo - PRONATEC TURISMO, Portaria no 281, de 11 de outubro de 2013. Brasília, MTur, 2013x.

BRASIL. Ministério do Turismo. Estabelece regras e critérios de execução e monitoramento do Programa Nacional de Acesso ao Ensino Técnico e Emprego, no âmbito do Ministério do Turismo - PRONATEC TURISMO, Portaria no 76, de 20 de maio de 2015. Brasília, MTur, 2015t.

BRASIL. Ministério do Turismo. Relatório de Diligência Presencial PRONATEC TURISMO (Curitiba). Brasília: MTur, 2014u.

BRASIL. Ministério do Turismo. Relatório de Diligência Presencial PRONATEC TURISMO (Salvador). Brasília: MTur, 2014v.

BRASIL. Ministério do Turismo. Dispõe sobre as diretrizes do Programa Nacional de Qualificação Profissional e Empresarial do Turismo e formaliza o Programa 
Bem Receber Copa. Portaria, № 90 de 22 de dezembro de 2010. Brasília, MTur, 2010r.

BRASIL. Ministério do Turismo. Subsídios para a formulação de ações de qualificação profissional pelo Ministério do Turismo. Brasília: MTur, 2011aa.

BRASIL. Ministério do Turismo. Índice de Competitividade do Turismo Nacional. RELATÓRIO BRASIL 2013. Brasília, MTur, 2013bb.

BRASIL. Ministério do Turismo. Relatório de Análise Documental Qualificação em Turismo. Brasília: UnB/CET/NPPT, 2014cc.

BRASIL. Ministério do Turismo. Minuta do documento Relatório de Avaliação de Resultados: PRONATEC Turismo (Período: 2012 a 2014), 2015dd.

BRASIL. Ministério do Trabalho e Emprego. Secretaria de Políticas Públicas de Emprego. Plano Nacional de Qualificação do Trabalhador (PLANFOR). Brasília: MTE, 2001c.

BRASIL. Ministério do Trabalho e Emprego. Secretaria de Políticas Públicas de Emprego. Plano Nacional de Qualificação - PNQ: 2003-2007. Brasília, 2003.

BRASIL. Ministério do Trabalho e Emprego. Institui o Plano Nacional de Qualificação (PNQ) e estabelece critérios para transferência de recursos do Fundo de Amparo ao Trabalhador (FAT), ao PNQ. Resolução, n.. 333, de 10 de julho de 2003. Brasília: MTE, 2003.

BRASIL. Secretaria de Assuntos Estratégicos da Presidência da República. Instituto de Pesquisa Econômica Aplicada (IPEA). Políticas sociais: acompanhamento e análise, n. 20. Brasília: IPEA, 2015e.

BRASIL. Secretaria de Assuntos Estratégicos da Presidência da República. Instituto de Pesquisa Econômica Aplicada (IPEA) PRONATEC: múltiplos arranjos e ações para ampliar o acesso à educação profissional. 1919 Textos para discussão. Rio de Janeiro: IPEA, 2014g.

BRASIL. Secretaria de Assuntos Estratégicos da Presidência da República. Instituto de Pesquisa Econômica Aplicada (IPEA). Perfil da mão de obra do turismo no Brasil nas atividades características do turismo e em ocupações. Brasília: IPEA, 2014.

BRASIL. (Constituição de 1937) Constituição dos Estados Unidos do Brasil: promulgada em 10 de novembro de 1937. Brasília: D.O.U, 1937 .

BUSTElO, E. ; Bromley, R. (Org.) Política X Técnica no Planejamento: perspectivas e críticas. São Paulo: Unicef; Brasiliense, 1982. 
CANALI, H.H.B. A trajetória da Educação Profissional no Brasil e os Desafios da Construção de um Ensino Médio Integrado à Educação profissional. In: Portal do Professor, 2014. 21p. Acessado em ago. 2016. file:///C:/Users/lenovo\%20user/Downloads/profissional\%2032.pdf.

CASALIS A. et al. Empregabilidade e Educação: novos caminhos no mundo do trabalho. São Paulo: Educ, 1997.

CARVALHO, O. F. Educação e Formação Profissional: Trabalho e Tempo Livre. Brasília: Plano Editora, 2003.

CASTIONI, R. Educação no Mundo do Trabalho: qualificação e competência. São Paulo: Francis, 2010.

CELLARD, A. Análise Documental. In: POUPART, Jean (org.). A pesquisa Qualitativa- enfoques epistemológicos e metodológicos. Petrópolis: Ed. Vozes, 2008.

CONCELHO NACIONAL DA EDUCAÇÃO. Parecer CNE/CES № 436/2001. Trata de Cursos Superiores de Tecnologia: Formação de Tecnólogos. Brasília: CNE, 2001.

COUTROT, T. Trabajo, empleo, actividad. In. GENTILLI P. ; FRIGOTTO G. (Coordenadores). Educacion, trabaho y exclusión social. CLACSO. Rio de Janeiro, 2000. CLACSO. Rio de Janeiro RJ, 2000.

DELORS, J. Educação: um tesouro a descobrir. São Paulo: Cortez; Brasília, DF: MEC: UNESCO, 1998.

DEMO, P. Pobreza Política, Coleção Polêmicas do nosso tempo. São Paulo: Cortez Autores Associados, 1991.

Política social, educação e cidadania. Campinas, SP: Papirus, 1994. .Dialética hoje. Petrópolis: Vozes, 1990.

Metodologia do conhecimento científico. São Paulo/SP; Atlas, 2000.

FONSECA, C. História do Ensino Industrial no Brasil. Rio de Janeiro: Escola Técnica, 1961. v.1.

FREIRE, P. Educação como prática da liberdade. $7^{\text {ạ }}$ Edição. Rio de Janeiro. Paz e Terra, 1977.

Pedagogia da autonomia: saberes necessários a prática educativa. São Paulo: Paz e Terra, 1996. 
FRIGOTTO, G. Educação e Trabalho: bases para debater a Educação Profissional Emancipadora. In: Revista Perspectiva V. 19. Florianópolis, 2001. 17p. GASTAL, S.; MOESCH, M. Turismo, políticas públicas e cidadania. São Paulo: Aleph, 2007.

GENTILLI P.; FRIGOTTO G. (Coordenadores). Grupo de Trabalho. Educacion, trabaho y exclusión social. CLACSO. Rio de Janeiro, 2000.

GROSS, B. In, BUSTElO E. ; Bromley R. (Org.) Política X Técnica no Planejamento: perspectivas e críticas. São Paulo: Unicef; Brasiliense, 1982.

GUERRA, I. Pesquisa qualitativa e análise de conteúdo: Sentidos e formas de uso. Cascais: Principia, 2006.

ARENDT, H. A condição humana. Rio de Janeiro: Forense Universitária, 2001.

HEIDEMANN, F. G. ; SALM, J. F. Políticas Públicas e Desenvolvimento: bases epistemológicas e modelos de análises. Brasília: Editora Universidade de Brasília, $3^{\text {a }}$ edição, 2014.

IVO, Anete B. L. Dicionário temático de desenvolvimento e questão social: 81 problemáticas contemporâneas. São Paulo: Annablume; Brasília: CNPq; Salvador: Fapesb, 2013.

JORGE, T. Políticas Públicas de Qualificação Profissional no Brasil: Uma análise a partir do PLANFOR e do PNQ. 2009. 117f. Mestre (Dissertação apresentada ao Programa de Pós-graduação em Educação, Conhecimento e Inclusão Social) Faculdade de Educação da Universidade Federal de Minas Gerais. Belo Horizonte, 2009.

KAPLAN, M. In BUSTELO E. ; Bromley R. (Org.) Política X Técnica no Planejamento: perspectivas e críticas. São Paulo: Unicef; Brasiliense, 1982.

KONDER, L. O que é dialética. São Paulo: Brasiliense, 2008.

KOSIK, Karel. A dialética do concreto. Tradução de Célia Neves e Alderico Toríbio. 2.ed. Rio de Janeiro: Paz e Terra, 1976.

KUNZER, A. Educação e Trabalho no Brasil: o estado da questão. Brasília. INEP, 1991.

KRIPPENDORF, J. Sociologia do Turismo: Para uma nova compreensão do lazer e das viagens. São Paulo: Aleph, 3aㅡ edição, 2001.

MARTONI, R. Por uma ontologia do espaço turístico: contribuições para uma consciência do real e do possível. 2014. 337f. Tese (Doutorado em geografia) Universidade Federal do Paraná - UFPR. Curitiba, 2014. 
MOESCH, M. (org.) Esboço do Documento de Referência para a Formulação da Política Nacional de Qualificação em Turismo. Brasília: UnB/CET/NPPT, 2016.

MOESCH, M. (org.) Pesquisa Avaliativa dos Arranjos Territoriais Possibilitadores da Qualificação em Turismo. Brasília: UnB/CET/NPPT, 2016.

MOESCH, M. A Produção do Saber Turístico. 2 ed. São Paulo: Contexto, 2002.

MORIN, E. Os setes saberes necessários à educação do futuro. Revista Educação e Sociedade. Campinas, vol. 25, n. 87, p. 383-399, maio/ago. 2004.

MORIN, Edgar; KERN, Anne-Brigitte. Terra Pátria. Tradução: Paulo Azevedo Neves da Silva. 5르 ed. Sulina. Porto Alegre, 2005.

NEVES, Lúcia M. W. Brasil Ano 2000: Uma nova divisão de trabalho na educação. Rio de Janeiro: Papéis e Cópias, 1997.

Organização Internacional do Trabalho. Certificação de Competências Profissionais - Análise Qualitativa do Trabalho, Avaliação e Certificação de Competências - Referenciais Metodológicos - Reedição. Brasília: OIT, 2002.

ORGANIZAÇÃO MUNDIAL DO TURISMO. Panorama OMT del turismo internacional - Edición 2015. Disponível em: <http://www.eunwto.org/doi/pdf/10.18111/9789284416875>. Acesso em: 20 fev. 2016.

PARENTE, J. Planejamento estratégico na Educação. Brasília: Liber Livro, 2010.

PAULO, NETTO, J. Introdução ao estudo do método de Marx. São Paulo: Expressão Popular, 2011.

PEIXOTO, P. E. Do PLANFOR ao PNQ: uma análise comparativa sobre os planos de qualificação no Brasil. 2008. 137 F. Dissertação (Mestrado em Política Social) Universidade Federal do Espírito Santo. Vitória, 2008.

POUPART, Jean et al. A pesquisa qualitativa: enfoques epistemológicos e metodológicos. Petrópolis, RJ: Vozes, 2008.

POCHMANN, M. Educação e Trabalho: como desenvolver uma relação virtuosa?. São Paulo: Cortez, 2004.

PNUD. Relatório do Desenvolvimento Humano. O Trabalho como Motor do Desenvolvimento Humano. 2015.

RODRIGUES, M. Políticas Públicas. São Paulo: Publifolha, 2010. 
SACHS, I. Desenvolvimento includente, sustentável, sustentado. Rio de Janeiro: Garamond, 2008.

SANTOS, M. R. Aspectos Históricos da Educação Profissional: Um plano de comunicação para atingir o público alvo do PRONATEC - Programa Nacional de Acesso ao Ensino Técnico e Emprego. 2013. 136 f. Dissertação (Mestrado em educação) Universidade de Brasília (UnB). Brasília, DF. 2013.

SARUP, M. Marxismo e Educação. Abordagem fenomenológica e marxista da educação. Rio de Janeiro: Zahar, 1980.

SAUL, A. M. ; FREITAS, J. C. Políticas públicas de Qualificação: Desafios atuais. São Paulo: A+ Comunicação, 2007.

SAVIANI, D. Escola e Democracia. São Paulo. Cortez, 1983.

SHEPPARD, M. Social work and social exclusion: the idea of practice. Aldershot: Ashgate, 2006.

SILVA, S. R. P. “A Nova” Política Pública De Qualificação Profissional do Brasil: Contribuições para uma análise crítica do Planfor e do PNQ. 2011. 295 f. Tese (Doutorado em educação) Universidade Federal de Pernambuco - Centro de Educação, Recife, 2011.

SILVA, R.C.S. Políticas de Qualificação Profissional no Brasil: entre o PLANFOR e o PNQ In: IV JORNADA INTERNACIONAL DE POLÍTICAS PÚBLICAS. Universidade Federal do Maranhão, 2009. p. 9.

SILVA, J. Cidadania e reconhecimento. In. AVRITZER L.; DOMINGUES J. (org.) Teoria social e Modernidade no Brasil. Belo Horizonte: Editora UFMG, 2000.

TEIXEIRA, R. M. Ensino superior em turismo e hotelaria no Brasil: um estudo exploratório. In.: Revista Turismo Em Análise, 12(2), 2001. p. 7-31.

TRIVIÑOS, A. Introdução à pesquisa em ciências sociais: a pesquisa qualitativa em educação. $1^{\text {a }}$ edição. São Paulo: Altas, 2011. 


\section{EIXO AMBIENTE, SAÚDE E SEGURANÇA}

1. agente de limpeza urbana

2. atendente de nutrição

3. bombeiro civil

\section{EIXO APOIO EDUCACIONAL}

4. contador de histórias

5. espanhol aplicado a serviços turísticos - básico

6. espanhol básico

7. francês básico

8. inglês aplicado a serviços turísticos - básico

9. inglês básico

10. inglês intermediário

11. libras básico

12. recreador

\section{EIXO GESTÃO E NEGÓCIOS}

13. auxiliar administrativo

14. auxiliar de faturamento

15. auxiliar de pessoal

16. auxiliar de recursos humanos

17. mensageiro

\section{EIXO HOSPITALIDADE E LAZER}

18. agente de informações turísticas

19. agente de viagens

20. atendente de lanchonete

21. auxiliar de agenciamento de viagens

22. auxiliar de confeitaria

23. auxiliar de cozinha

24. bartender

25. camareira em meios de hospedagem

26. churrasqueiro

27. condutor de turismo de aventura

28. copeiro

29. garçom básico

30. masseiro

31. mensageiro em meio de hospedagem

32. mestre de cerimonias

33. monitor ambiental

34. monitor de recreação

35. organizador de eventos

36. padeiro

37. padeiro e confeiteiro

38. pizzaiolo 
39. recepcionista

40. recepcionista de eventos

41. recepcionista em meios de hospedagem

42. salgadeiro

43. sommelier

44. sushiman

5. EIXO INFORMAÇÃO E COMUNICAÇÃO

45. instalador de rede de tv a cabo e via satélite

46. instalador e reparador de linhas e sistemas de telefonia

47. programador web

6. EIXO PRODUÇÃO ALIMENTÍCIA

48. confeiteiro

49. operador industrial de alimentos

\section{EIXO PRODUÇÃO CULTURAL E DESIGN}

50. operador de áudio

51.operador de câmera

52. produtor cultural 


\section{ANEXO B - CURSOS- PRONATEC TURISMO CIDADÃO}

\section{1 - EIXO TURISMO, HOSPITALIDADE E LAZER}

1. Agente de informações turísticas

2. Agente de reservas em meios de hospedagem

3. Atendente de lanchonete

4. Auxiliar de Cozinha

5. Barista

6. Bartender

7. Camareira em meios de hospedagem

8. Cerimonialista

9. Churrasqueiro

10. Condutor de Turismo de Pesca

11. Condutor de Turismo de Aventura

12. Copeiro

13. Cozinheiro

14. Concièrge

15. Cumim

16. Garçom

17. Mestre de Cerimônias

18. Mensageiro em meios de hospedagem

19. Monitor de Atividades de Lazer

20. Organizador de eventos

21. Pizzaiolo

22. Recepcionista em meios de meios de hospedagem

23. Recepcionista de eventos

24. Recreador

25. Salgadeiro

26. Sommelier

27. Sushiman 
ANEXO C - CURSOS PRONATEC TURISMO NA EMPRESA

\section{1 - EIXO INFRAESTRUTURA e EIXO SAÚDE E ESTÉTICA}

\subsection{Eixo Infraestrutura}

1. Agente de Limpeza Urbana

2. Agente de Aeroporto

\subsection{Eixo Saúde e Estética}

3. Atendente em nutrição e dietética

4. Massagista

\section{2 - EIXO DESENVOLVIMENTO EDUCACIONAL E SOCIAL}

5. Língua Brasileira de Sinais - LIBRAS Básico

6. Língua Brasileira de Sinais - LIBRAS Intermediário

7. Língua Brasileira de Sinais - LIBRAS Avançado

8. Introdução à Interpretação em Língua Brasileira de Sinais - LIBRAS

9. Guia Interprete

10. Espanhol Básico

11. Espanhol Intermediário

12. Francês Básico

13. Francês Intermediário

14. Inglês Básico

15. Inglês Intermediário

\section{3 - EIXO GESTÃO E NEGÓCIOS}

16. Assistente Administrativo

17. Assistente de faturamento

18. Assistente de recursos humanos

19. Mensageiro

20. Recepcionista

\section{4 - EIXO TURISMO, HOSPITALIDADE E LAZER}

21. Agente de Informações Turísticas

22. Agente de reservas em meios de hospedagem

23. Atendente de Lanchonete

24. Auxiliar de Cozinha

25. Barista

26. Bartender

27. Camareira em Meios de Hospedagem

28. Cerimonialista

29. Churrasqueiro

30. Condutor de Turismo de Aventura

31. Condutor de Turismo de Pesca

32. Copeiro

33. Cozinheiro

34. Conciérge

35. Cumim

36. Garçom

37. Inglês Aplicado a serviços Turísticos

38. Espanhol aplicado a serviços Turísticos 
39. Francês aplicado a serviços Turísticos

40. Mestre de Cerimônias

41. Mensageiro em Meios de Hospedagem

42. Monitor de Atividades de Lazer

43. Organizador de Eventos

44. Pizzaiolo

45. Recepcionista em Meios de Hospedagem

46. Recreador

47. Recepcionista de Eventos

48. Salgadeiro

49. Sommelier

50. Sushiman

5 - EIXO INFORMAÇÃO E COMUNICAÇÃO

51. Programador WEB

6 - EIXO PRODUÇÃO ALIMENTÍCIA

52. Confeiteiro

53. Cozinheiro Industrial

54. Pedreiro

55. Sorveteiro

7 - EIXO DE PRODUÇÃO ARTÍSTICA, CULTURAL E DESIGN

56. Agente cultural

57. Operador de edição e áudio 


\section{ANEXO D - CURSOS PRONATEC TURISMO SOCIAL}

\section{1 - EIXO GESTÃO E NEGÓCIOS}

1. Auxiliar Administrativo

2. Auxiliar de Faturamento

3. Auxiliar de Recursos Humanos

4. Mensageiro

5. Recepcionista

\section{2 - EIXO TURISMO, HOSPITALIDADE E LAZER}

6. Agente de Informações Turísticas

7. Agente de reservas em meios de hospedagem

8. Atendente de Lanchonete

9. Auxiliar de Cozinha

10. Barista

11. Bartender

12. Camareira em Meios de Hospedagem

13. Cerimonialista

14. Churrasqueiro

15. Conciergè

16. Condutor de Turismo de Aventura

17. Condutor de Turismo de Pesca

18. Copeiro

19. Cozinheiro

20. Garçom

21. Inglês aplicado a serviços turísticos

22. Espanhol aplicado a serviços turísticos

23. Francês aplicado a serviços turísticos

24. Mestre de Cerimônias

25. Mensageiro em Meios de Hospedagem

26. Monitor de Atividades de Lazer

27. Organizador de Eventos

28. Pizzaiolo

29. Recepcionista em Meios de Hospedagem

30. Recepcionista de Eventos

31. Recreador

32. Salgadeiro

33. Sommelier

34. Sushiman 


\section{ANEXO E - CURSOS PRONATEC DESENVOLVIMENTO LOCAL}

\section{EIXO CONTROLE DE PROCESSOS INDUSTRIAIS}

1. Laminador e pintor de embarcação em fibra de vidro

2. Pintor industrial

\section{EIXO INFRAESTRUTURA}

3. Marceneiro

\section{EIXO PRODUÇÃO ALIMENTÍCIA}

4. Destilador de bebidas

5. Cervejeiro

6. Confeiteiro

7. Operador de máquinas de produção de massas alimentícias

8. Operador de processamento de frutas e hortaliças

9. Operador de processamento de pescado

10. Padeiro

11. Preparador de doces em conservas

12. Produtor de bebidas alcoólicas

13. Produtor de bebidas não alcoólicas

14. Produtor de cachaça

15. Produtor de cervejas

16. Produtor de derivados do leite

17. Produtor de doce de leite

18. Produtor de embutidos e defumados

19. Produtor de frutas e hortaliças processadas com uso de acidificação

20. Produtor de frutas e hortaliças processadas com uso de calor

21. Produtor de frutas e hortaliças processadas com uso do frio

22. Produtor de frutas, hortaliças e plantas aromáticas processadas por secagem e desidratação

23. Produtor de licores

24. Produtor de produtos apícolas

25. Produtor de queijo

26. Produtor de vinhos e derivados da uva

27. Sorveteiro

\section{EIXO PRODUÇÃO ARTíSTICA, CULTURAL E DESIGN}

28. Aderecista

29. Agente cultural

30. Alfaiate

31. Artesão de artigos indígenas

32. Artesão de biojoias

33. Artesão de bordado à mão

34. Artesão de cerâmica

35. Artesão de pintura em tecido

36. Assistente de camarim 
37. Assistente de Figurinista

38. Assistente de produção cultural

39. Auxiliar de cenotecnia

40. Cartonageiro a mão

41. Confeccionador de acordeão

42. Confeccionador de bijuterias

43. Confeccionador de instrumentos de corda

44. Confeccionador de instrumentos de percussão

45. Confeccionador de instrumentos de sopro

46. Contrarregra

47. Desenhista de moda

48. Desenhista de móveis

49. Disc jóquei (DJ)

50. Dublador

51. Editor de projeto visual gráfico

52. Editor de vídeo

53. Eletricista de audiovisual

54. Estilista de calçados

55. Florista

56. Fotógrafo

57. lluminador cênico

58. Ilustrador

59. Locutor- apresentador- animador

60. Maquiador cênico

61. Maquinista de cenário

62. Marcheteiro

63. Operador de câmera

64. Operador de gravação de áudio

65. Pintor restaurador

66. Projetista de móveis

67. Regente de Banda Marciais e Fanfarra

68. Regente de coral

69. Revitalizador de estruturas de madeira

70. Revitalizador de revestimentos argamassados

71. Sonoplasta

72. Tradutor e elaborador de legendas

73. Vitrinista

\section{EIXO PRODUÇÃO INDUSTRIAL}

74. Auxiliar em fabricação de refratários

75. Boneleiro

76. Classificador de couros

77. Confeccionador de bolsas em couro e material sintético

78. Confeccionador de bolsas em tecido

79. Confeccionador de calçados

80. Confeccionador de sandálias de couro e material sintético

81. Confeccionador de vestuário de couro 
82. Costureiro de calçados

83. Costureiro de Máquina Reta e Overloque

84. Cravejador de joias

85. Curtidor de couros e peles

86. Estampador de tecido

87. Estofador de móveis

88. Fabricador de fogos de artificio

89. Fundidor de joias

90. Gravador e joias

91. Inspetor de Qualidade

92. Joalheiro

93. Lapidador de gemas

94. Modelista de roupas

95. Montador e Acabador de Calçados

96. Operador de máquinas de marcenaria

97. Operador de Processos Cerâmicos

98. Operador de processos da indústria têxtil

99. Operador de processos de estamparia para joias

100. Ourives

101. Pintor de móveis

102. Serígrafo

103. Tecelão

\section{EIXO RECURSOS NATURAIS}

104. Açaicultor

105. Administrador de empreendimentos florestais de base comunitária

106. Agente de Gestão de Resíduos Sólidos

107. Agilcutor

108. Agricultor agroflorestal

109. Agricultor familiar

110. Agricultor orgânico

111. Apicultor

112. Aquicultor

113. Auxiliar de agroecologia

114. Auxiliar de agropecuária

115. Auxiliar de fiscalização ambiental

116. Auxiliar de laboratório de saneamento

117. Avicultor

118. Beneficiador de produtos extrativistas

119. Cacauicultor

120. Cafeicultor

121. Caprinocultor

122. Criador de peixes em tanque rede

123. Criador de peixes em viveiros escavados

124. Dendeicultor

125. Equideocultor

126. Floricultor 
127. Fruticultor

128. Horticultor orgânico

129. Manejador de florestas nativas para uso múltiplo

130. Marisqueiro

131. Meliponicultor

132. Operador de aterro sanitário de resíduos sólidos urbanos

133. Operador de beneficiamento de pescado

134. Operador de produção em unidade de tratamento de resíduos

135. Ovinocultor

136. Pescador

137. Pescador profissional

138. Piscicultor

139. Preparador de pescado

140. Produtor agropecuário

141. Produtor de mandioca

142. Produtor de olerícolas

143. Produtor de plantas aromáticas e medicinais

144. Produtor familiar de cana-de-açúcar

145. Reciclador

146. Redeiro

147. Viveiricultor

\section{EIXO GESTÃO DE NEGÓCIOS}

148. Vendedor

149. Agente de desenvolvimento cooperativista

150. Agente de inspeção de qualidade

151. Agente de microcrédito

152. Assistente de Planejamento, Programação e Controle de Produção

153. Operador de telemarketing

154. Promotor de vendas

\section{EIXO DESENVOLVIMENTO EDUCACIONAL E SOCIAL}

155. Auxiliar de equoterapia

156. Língua portuguesa e cultura brasileira para surdos (básico)

157. Língua portuguesa e cultura brasileira para surdos (intermediário)

158. Agente de Desenvolvimento Socioambiental

TOTAL DE PRONATEC TURISMO: 158 
Acre

1. Rio Branco

Alagoas

2. Maceió

3. Maragogi

4. Marechal Deodoro

5. Penedo

6. Piranhas

Amapá

7. Macapá

8. Serra do Navio

Amazonas

9. Manaus

10. Iranduba

11. Manacapuru

12. Novo Airão

13. Presidente Figueiredo

14. Rio Preto da Eva

\section{Bahia}

15. Salvador

16. Cachoeira

17. Cairu

18. Itaparica

19. Lauro de Freitas

20. Lençóis

21. Maragogipe

22. Mata de São João
23. Monte Santo

24. Mucugê

25. Porto Seguro

26. São Félix

27. Vera Cruz

\section{Ceará}

28. Fortaleza

29. Aquiraz

30. Aracati

31. Beberibe

32. Carnaubal

33. Cascavel

34. Caucaia

35. Guaraciaba do Norte

36. Jijoca de Jericoacoara

37. Ibiapina

38. Icó

39. Ipu

40. Paraipaba

41. São Benedito

42. Sobral

43. Tianguá

44. Ubajara

45. Viçosa do Ceará

Distrito Federal

46. Brasília

\section{Espírito Santo}

47. Vitória 
Goiás

48. Goiânia

49. Alto Paraíso

50. Cavalcante

51. Cidade de Goiás

52. Corumbá de Goiás

53. Formosa

54. Pirenópolis

55. São João D'Aliança

56. Teresina de Goiás

Maranhão

57. São Luís

58. Alcântara

59. Barreirinhas

60. Humberto de Campos

61. Primeira Cruz

62. Santo Amaro do Maranhão

Mato Grosso

63. Cuiabá

64. Acorizal

65. Chapada dos Guimarães

66. Jangada

67. Nobres

68. Nortelândia

69. Poconé

70. Rosário Oeste

71. Santa Rita do Trivelato

72. São José do Rio Claro

73. Várzea Grande

Mato Grosso do Sul

74. Campo Grande
75. Aquidauana

76. Bonito

77. Corumbá

78. Jardim

79. Miranda

Minas Gerais

80. Belo Horizonte

81. Aiuruoca

82. Alagoa

83. Brumadinho

84. Cataguases

85. Conceição do Mato Dentro

86. Congonhas

87. Congonhas do Norte

88. Diamantina

89. Dom Joaquim

90. Itamonte

91. Itanhandu

92. Jaboticatubas

93. Mariana

94. Morro do Pilar

95. Nova Lima

96. Ouro Branco

97. Ouro Preto 98. Passa Quatro

99. Pouso Alto

100. Raposos

101. Sabará

102. Santana do Riacho

103. São João Del Rei

104. São Sebastião do Rio Verde

105. Sete Lagoas 
106. Tiradentes

107. Virgínia

Pará

108. Belém

Paraíba

109. João Pessoa

Pernambuco

110. Recife

111. Cabo de Santo Agostinho

112. Caruaru

113. Fernando de Noronha

114. Ilha de Itamaracá

115. Ipojuca

116. Jaboatão dos Guararapes

117. Olinda

118. Igarassu

119. Tamandaré

Piauí

120. Teresina

121. Oeiras

122. Parnaíba

123. Piracuruca

124. São Raimundo Nonato

Paraná

125. Curitiba

126. Antonina

127. Foz do Iguaçu

128. Guaraqueçaba

129. Lapa

130. Morretes

131. Paranaguá
132. Ponta Grossa

133. São José dos Pinhais

Rio de Janeiro

134. Rio de Janeiro

135. Angra dos Reis

136. Armação dos Búzios

137. Arraial do Cabo

138. Cabo Frio

139. Cachoeiras de Macacu

140. Guapimirim

141. Itatiaia

142. Mangaratiba

143. Niterói

144. Nova Friburgo

145. Paraty

146. Petrópolis

147. Porto Real

148. Quatis

149. Resende

150. Rio das Ostras

151. Teresópolis

152. Vassouras

Rio Grande do Norte

153. Natal

154. Baia Formosa

155. Canguaretama

156. Maxaranguape

157. Parnamirim

158. Tibau do Sul

Rio Grande do Sul

159. Porto Alegre 
160. André da Rocha

161. Bento Gonçalves

162. Bom Jesus

163. Cambará do Sul

164. Canela

165. Canoas

166. Capão Bonito do Sul

167. Caxias do Sul

168. Chuí

169. Esmeralda

170. Garibaldi

171. Gramado

172. Jaguarão

173. Jaquirana

174. Monte Alegre dos Campos

175. Muitos Capões

176. Nova Petrópolis

177. Novo Hamburgo

178. Pinhal da Serra

179. Santana do Livramento

180. São Borja

181. São José dos Ausentes

182. São Miguel das Missões

183. Uruguaiana

184. Vacaria

Roraima

185. Boa Vista

São Paulo

186. São Paulo

187. Atibaia

188. Campinas
189. Carapicuíba

190. Guarujá

191. Ilhabela

192. Peruíbe

193. Santo André

194. Santos

195. São Vicente

\section{Santa Catarina}

196. Florianópolis

197. Araranguá

198. Balneário Arroio do Silva

199. Balneário Camboriú

200. Balneário Gaivota

201. Jacinto Machado

202. Laguna

203. Maracajá

204. Passo de Torres

205. Praia Grande

206. São Francisco do Sul

207. Sombrio

208. Timbé do Sul

\section{Sergipe}

209. Aracaju

210. Laranjeiras

211. São Cristóvão

Tocantins

212. Palmas

213. Natividade

214. Porto Nacional 


\section{ANEXO G - INSTITUIÇÕES EXECUTANTES DO PRONATEC (CIDADES SEDES)}

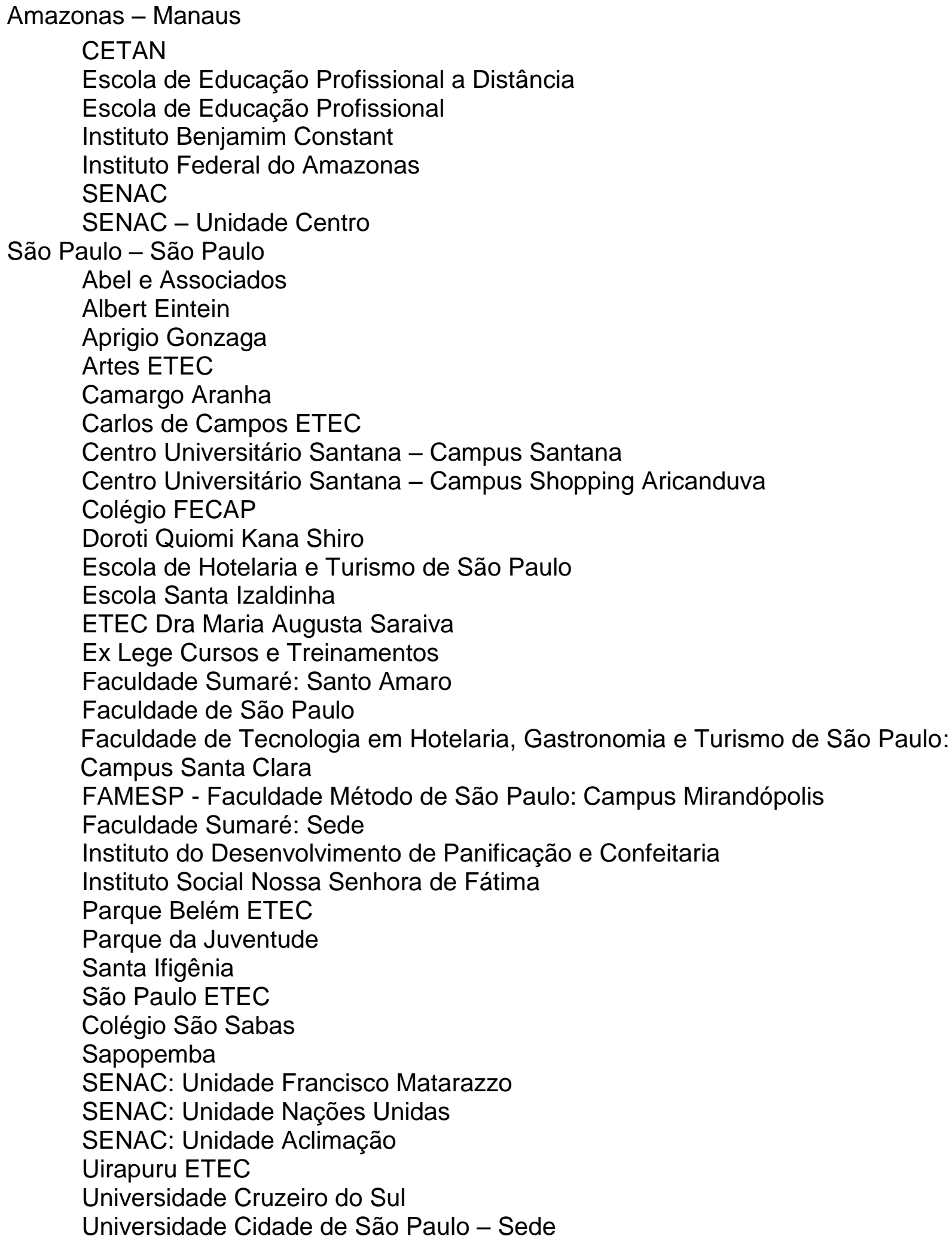


Universidade Guarulhos - Campus São Paulo-Sede

Paraná - Curitiba

Centro de Educação profissional Irmão Mario Cristóvão: TECPUC

Colégio Estadual Julia Wanderley

Colégio Estadual Pedro Macedo

Faculdade OPET: Rebouças

Instituto Federal do Paraná

Unidade de Educação Profissional de Curitiba

Rio de Janeiro - Rio de Janeiro

C.E. Infante Dom Henrique

CIAA: Centro de Instrução Almirante Alexandrino

Centro Educacional Vida e Arte

Centro Federal de Educação Tecnológica Celso Suckow da Fonseca:

Campus Maracanã

CETAP: Centro de Ensino e Treinamento Aplicado a Profissionais

COL Realengo

Colégio Castelo Branco

Colégio de Aplicação Dr. Paulo Gissoni

Colégio e Curso Daltro Netto

Colégio Estadual Antônio Prado Junior

Colégio Internacional Signorelle

Escola Técnica Sistema

Faculdade Gama e Souza: Campus II

FATEC: Centro de Educação Tecnológica e Profissionalizante Ipanema

FAETEC: Centro Vocacional Tecnológico Cidade de Deus

FAETEC: Escola Técnica Estadual Adolpho Bloch

SENAC: unidade campo Grande

SENAC: Unidade Centro de Turismo e Hotelaria

SENAC: Unidade Copacabana

SENAC: Unidade Centro Politécnico

SENAC: Unidade FAETEC

SENAC: Unidade Irajá

SENAC: Unidade Madureira

SENAC: Unidade Botafogo

Serviço Nacional de Aprendizagem Comercial: ARRJ

Minas Gerais - Belo Horizonte

Centro Federal de Educação tecnológica de Minas Gerais

Escola de Educação Profissional Newton Paiva: Campus Caiçara

Escola de Educação Profissional Newton Paiva: Campus III

Escola Técnica Profissional de Nível Médio do SITIPAN

Instituto Cultural Boa Esperança

SENAC

SENAI: Unidade Américo Rene Giannetti

Universidade Federal de Minas Gerais - Colégio Técnico

Rio Grande do Norte - Natal

Centro Universitário FACEX

Hotel Escola SENAC Barreira Roxa 
Hotel Escola SENAC

Instituto Federal do Rio Grande do Norte: Campus Central

Instituto Federal do Rio Grande do Norte: Campus Cidade Alta

SENAI

Instituto Federal do Rio Grande do Norte

Ceará - Fortaleza

Centro Federal de Educação

Escola de Educação Profissional Joaquim Antônio Albano

Escola de Educação Profissional Joaquim Nogueira

Escola de Educação Profissional Joaquim Nogueira

Escola de Educação Profissional Marechal Juarez Távora

Escola de Educação Profissional Mario Alencar

Escola de Educação Profissional Marvim

Escola de Educação Profissional Paulo VI

Escola de Turismo do Ceara

Escola Estadual de Educação profissional Paulo Petrola

Escola Estadual de Educação profissional Ícaro de Sousa Moreira

Instituto Centro de Ensino Tecnológico

Instituto Federal do Ceara

SENAC

SENAI - Campus CETREM

Pernambuco - Recife

Centro de Educação Profissional: CEPRO

Centro de Educação Profissional Joaquim Nabuco II

Centro de Educação Profissional Maurício de Nassau II

Centro de Estudos de Saúde

Centro Universitário Maurício de Nassau: Campus Bloco B

Centro Universitário Maurício de Nassau: Campus Recife B

Centro Universitário Maurício de Nassau

Escola Técnica Estadual Almirante Soares Dutra

Escola Técnica Estadual Professor Agamenon Magalhães

Escola Técnica Regional

Faculdade Joaquim Nabuco: Recife

Faculdade Joaquim Nabuco: Campus Sede

Instituto Federal de Pernambuco

SENAC

Rio Grande do Sul - Porto Alegre

Escola de Educação Profissional FACTUM

Escola Municipal de Ensino Médio Emilio Neyer

Instituto Federal do Rio Grande do Sul

SENAC: Unidade Cidade Baixa

Distrito Federal - Brasília

Centro Cenecista de Educação Profissional Felipe Tiago Gomes

IESB: Campus Asa Sul

IESB: Campus Oeste

IESB: Campus Sede

Instituto Federal de Brasília: Campus Brasília 
Instituto Federal de Brasília: Campus Avançado Riacho Fundo Instituto Federal de Brasília: Campus Planaltina Instituto Federal de Brasília: Campus Riacho Fundo Instituto Federal de Brasília: Campus Taguatinga Mato Grosso - Cuiabá

Centro de Educação de Jovens e Adultos Antônio Cesário Neto Instituto Federal do Mato Grosso

SENAC

Bahia - Salvador

Centro de Tecnologia da Bahia

Centro de Educação Profissional da Bahia

Centro de Educação Profissional em Gestão Severino Vieira

Centro de Educação Profissional em Saúde e Tecnologia da Informação

Centro Universitário Jorge Amado

Centro Universitário Jorge Amado: Campus Paralela

Colégio Estadual Governador Lomanto Junior

Colégio Estadual Thales de Azevedo

Colégio Maria Cancio de Souza

Escola Técnica da Casa Pia e Colégio dos Órfãos de São Joaquim

Faculdade Maurício de Nassau

INET: Instituto de Educação tecnológica

Instituto Federal da Bahia

OTEC: Cursos Técnicos

SENAC: Unidade Móvel

SENAC

SENAI 
APÊNDICE A - AnÁlise de Conteúdo: Categoria Inclusão social e Categoria Desenvolvimento Humano/Cidadania

Brasília -6 entrevistas (egressos, gestores e instrutores do PRONATEC Turismo)

\begin{tabular}{|c|c|c|c|c|c|c|c|c|}
\hline \multicolumn{3}{|c|}{ CATEGORIAS A PRIORI } & \multicolumn{6}{|c|}{ CATEGORIAS MATERIALISMO HISTORICO-DIALETICO } \\
\hline Categorias & Concepções & Avanços & $\begin{array}{l}\text { Teoria } \\
\text { prática }\end{array}$ & $\begin{array}{l}\text { Totalidade } \\
\text { fragmentação }\end{array}$ & $\begin{array}{l}\text { Contradição } \\
\text { mediação }\end{array}$ & $\begin{array}{l}\text { Subjetividade } \\
\text { objetividade }\end{array}$ & $\begin{array}{l}\text { Autonomia } \\
\text { dependência }\end{array}$ & $\begin{array}{l}\text { Criticidade } \\
\text { alienação }\end{array}$ \\
\hline $\begin{array}{l}\text { Inclusão social: } \\
\text { a inclusão dos } \\
\text { sujeitos é } \\
\text { determinante para } \\
\text { uma vida ativa e o } \\
\text { equilíbrio das } \\
\text { oportunidades em } \\
\text { sociedade, } \\
\text { considerando que } \\
\text { essa inclusão } \\
\text { prioritariamente } \\
\text { começa pelo } \\
\text { acesso ao emprego } \\
\text { qualificante, } \\
\text { possibilitador do } \\
\text { crescimento } \\
\text { profissional, espaço } \\
\text { onde o trabalhador } \\
\text { possa criar, } \\
\text { desenvolver-se e } \\
\text { ter suas } \\
\text { individualidades } \\
\text { respeitadas. } \\
\text { Acesso aos direitos } \\
\text { sociais, políticos, } \\
\text { civis, econômicos, } \\
\text { culturais e ao lazer. }\end{array}$ & $\begin{array}{l}\text { "Pronatec } \\
\text { copa tinha } \\
\text { como } \\
\text { objetivo } \\
\text { inserir } \\
\text { pessoas no } \\
\text { mercado de } \\
\text { trabalho." }\end{array}$ & $\begin{array}{l}\text { "Não há } \\
\text { como falar } \\
\text { de } \\
\text { desenvolvim } \\
\text { ento, ou de } \\
\text { excelência } \\
\text { na prestação } \\
\text { de serviços } \\
\text { turísticos } \\
\text { sem falar de } \\
\text { qualificação". } \\
\text { "As } \\
\text { instituições } \\
\text { de ensino } \\
\text { deveriam } \\
\text { criar um } \\
\text { mecanismo } \\
\text { para acelerar } \\
\text { o intervalo da } \\
\text { pré matricula } \\
\text { até a } \\
\text { matricula e } \\
\text { também para } \\
\text { saber o real } \\
\text { motivo de } \\
\text { evadidos". }\end{array}$ & $\begin{array}{l}\text { “...foi bem aceito } \\
\text { pela comunidade } \\
\text { no momento da pré } \\
\text { inscrição, mas } \\
\text { como demorava } \\
\text { meses para realizar } \\
\text { a matricula } \\
\text { algumas pessoas já } \\
\text { não estavam mais } \\
\text { interessadas." } \\
\text { "O curso não } \\
\text { contribuiu para a } \\
\text { melhoria } \\
\text { profissional pois } \\
\text { não teve a chance } \\
\text { de trabalhar na } \\
\text { área (devido a } \\
\text { idade)." } \\
\text { "Muitos estavam lá } \\
\text { pois na época } \\
\text { estavam recebendo } \\
\text { seguro } \\
\text { desemprego e tinha } \\
\text { que estar fazendo } \\
\text { um curso". }\end{array}$ & $\begin{array}{l}\text { "O setor e o estado } \\
\text { veem como forma de } \\
\text { fornecer mais } \\
\text { qualificação, missão } \\
\text { de inserção, onde } \\
\text { pela visão da gestora } \\
\text { deveria começar } \\
\text { desde o ensino } \\
\text { médio." } \\
\text { "A proposta era de } \\
\text { que essas pessoas } \\
\text { iriam ser } \\
\text { aproveitadas na copa } \\
\text { do mundo, e isso não } \\
\text { aconteceu". } \\
\text { "Os Cursos de } \\
\text { Turismo e Hotelaria } \\
\text { principalmente eu } \\
\text { sinto na pele que } \\
\text { ninguém sabe do } \\
\text { que se trata". } \\
\text { "O contato que eu } \\
\text { sempre tive foram } \\
\text { com os hotéis. Eles } \\
\text { ficavam implorando } \\
\text { para mandar aluno } \\
\text { pra fazer estágio lá". }\end{array}$ & $\begin{array}{l}\text { "Muitos } \\
\text { empresários } \\
\text { não estavam } \\
\text { dispostos a } \\
\text { liberar seus } \\
\text { funcionários } \\
\text { para fazer a } \\
\text { qualificação, } \\
\text { pois } \\
\text { atrapalharia } \\
\text { o horário de } \\
\text { trabalho". } \\
\text { "Não tenho } \\
\text { conheciment } \\
\text { o formal } \\
\text { sobre isso, } \\
\text { mas alguns } \\
\text { alunos estão } \\
\text { trabalhando } \\
\text { sim na área. } \\
\text { Muitas } \\
\text { falaram que } \\
\text { o curso de } \\
\text { idioma está } \\
\text { ajudando } \\
\text { muito no } \\
\text { trabalho." }\end{array}$ & $\begin{array}{l}\text { "Consegui } \\
\text { trabalho na área } \\
\text { mas não fiquei." } \\
\text { "Não muito, } \\
\text { ainda não } \\
\text { apliquei. As } \\
\text { técnicas que eu } \\
\text { aprendi eu ainda } \\
\text { não apliquei } \\
\text { porque ainda } \\
\text { não entrei em } \\
\text { uma empresa } \\
\text { que exigisse de } \\
\text { mim esse } \\
\text { aprendizado." } \\
\text { "Muitas se } \\
\text { formaram no } \\
\text { curso do } \\
\text { Pronatec, então } \\
\text { seguiram para o } \\
\text { estágio e muitos } \\
\text { agora estão } \\
\text { trabalhando". }\end{array}$ & $\begin{array}{l}\text { "Se aparecer } \\
\text { oportunidade } \\
\text { gostaria muito } \\
\text { trabalharia na } \\
\text { área, porém } \\
\text { não é a } \\
\text { primeira } \\
\text { opção". } \\
\text { “...mas em } \\
\text { compensação } \\
\text { o mercado não } \\
\text { absorveu } \\
\text { muitos desses } \\
\text { alunos por } \\
\text { considerar que } \\
\text { estes não } \\
\text { concluíam, } \\
\text { devidamente, } \\
\text { qualificados." }\end{array}$ & $\begin{array}{l}\text { "Eu tive um } \\
\text { aluno que era } \\
\text { mecânico e ele } \\
\text { foi colocado } \\
\text { em um curso } \\
\text { de camareira". } \\
\text { "Muita evasão } \\
\text { aconteceu } \\
\text { pela falta de } \\
\text { interesse, } \\
\text { onde muitos } \\
\text { estavam } \\
\text { interessados } \\
\text { pelo dinheiro } \\
\text { onde de } 100 \\
\text { aulas, o aluno } \\
\text { foi em } 20 \text { ". } \\
\text { "Falta de } \\
\text { interesse por } \\
\text { parte da } \\
\text { política." }\end{array}$ \\
\hline
\end{tabular}




\begin{tabular}{|c|c|c|c|c|c|c|c|c|}
\hline \multicolumn{3}{|c|}{ CATEGORIAS A PRIORI } & \multicolumn{6}{|c|}{ CATEGORIAS MATERIALISMO HISTORICO-DIALETICO } \\
\hline Categorias & Concepções & Avanços & $\begin{array}{l}\text { Teoria } \\
\text { prática }\end{array}$ & $\begin{array}{l}\text { Totalidade } \\
\text { fragmentação }\end{array}$ & $\begin{array}{l}\text { Contradição } \\
\text { mediação }\end{array}$ & $\begin{array}{l}\text { Subjetividade } \\
\text { objetividade }\end{array}$ & $\begin{array}{l}\text { Autonomia } \\
\text { dependência }\end{array}$ & $\begin{array}{l}\text { Criticidade } \\
\text { alienação }\end{array}$ \\
\hline $\begin{array}{l}\text { Desenvolvimento } \\
\text { humano/ } \\
\text { Cidadania } \\
\text { E intrínseco ao } \\
\text { desenvolvimento } \\
\text { humano a } \\
\text { cidadania que } \\
\text { pressupõe } \\
\text { equidade de } \\
\text { oportunidades. } \\
\text { Tais como ingresso } \\
\text { ao trabalho digno, } \\
\text { acesso à } \\
\text { aposentadoria, à } \\
\text { segurança, à } \\
\text { habitação, à } \\
\text { educação, ao } \\
\text { direito, à cultura e } \\
\text { ao lazer, fatores } \\
\text { essenciais para a } \\
\text { consolidação da } \\
\text { cidadania. E } \\
\text { requisitos para o } \\
\text { desenvolvimento } \\
\text { humano, assim } \\
\text { como a educação } \\
\text { integral dos } \\
\text { sujeitos, que tenha } \\
\text { como objetivo a } \\
\text { cidadania, a } \\
\text { liberdade, a } \\
\text { autonomia e a } \\
\text { emancipação. }\end{array}$ & $\begin{array}{l}\text { "Esses } \\
\text { cursos } \\
\text { oferecidos } \\
\text { pelo } \\
\text { Pronatec tem } \\
\text { uma } \\
\text { proposta de } \\
\text { alguns temas } \\
\text { transversais } \\
\text { de } \\
\text { cidadania”. } \\
\text { “...isso é a } \\
\text { questão de } \\
\text { cidadania } \\
\text { também, de } \\
\text { você } \\
\text { pertencer, pq } \\
\text { você começa } \\
\text { a conhecer e } \\
\text { você começa } \\
\text { a pertencer e } \\
\text { aí você } \\
\text { cuida.” }\end{array}$ & $\begin{array}{l}\text { "Dentro dos } \\
\text { cursos do } \\
\text { pronatec que } \\
\text { eu atuei, } \\
\text { tinha } \\
\text { inclusive um } \\
\text { dos itens que } \\
\text { a gente } \\
\text { trabalhava } \\
\text { muito era } \\
\text { "vida, } \\
\text { trabalho, } \\
\text { oportunidade } \\
\text { de trabalho, } \\
\text { sustentabilid } \\
\text { ade." } \\
\text { "sempre } \\
\text { trabalhei com } \\
\text { isso, que } \\
\text { cada um } \\
\text { trouxesse um } \\
\text { pouco da sua } \\
\text { comunidade, } \\
\text { assim o que } \\
\text { eles } \\
\text { conhecem } \\
\text { pra que a } \\
\text { gente } \\
\text { pudesse } \\
\text { juntar tudo e } \\
\text { desenvolver." }\end{array}$ & $\begin{array}{l}\text { "a carga horaria } \\
\text { do curso deveria } \\
\text { ser maior para } \\
\text { assim ter uma } \\
\text { melhor } \\
\text { qualificação". } \\
\text { "Não havia muito } \\
\text { interesse no } \\
\text { curso, muito } \\
\text { estavam ali para } \\
\text { receber o dinheiro } \\
\text { financiado". } \\
\text { "Influenciou. Hoje } \\
\text { se eu tiver a } \\
\text { oportunidade de } \\
\text { fazer esses } \\
\text { cursos eu faço." } \\
\text { "sentiu falta de } \\
\text { uma apostila } \\
\text { (material de } \\
\text { apoio) para } \\
\text { melhor } \\
\text { aprendizagem" }\end{array}$ & $\begin{array}{l}\text { "Sim. Eu acho que } \\
\text { só faltou } \\
\text { oportunidades } \\
\text { porque infelizmente } \\
\text { ainda não há essa } \\
\text { abertura, é uma } \\
\text { coisa muito fechada. } \\
\text { Acho que ainda } \\
\text { pode melhorar para } \\
\text { que a gente possa } \\
\text { mostrar esses } \\
\text { conhecimentos." } \\
\text { "Egressa se } \\
\text { interessou mais por } \\
\text { questões sociais } \\
\text { depois do curso". } \\
\text { "tem muita evasão... } \\
\text { as turmas } \\
\text { começavam com } 40 \\
\text { (45) e terminavam } \\
\text { com 12, 13. Eu acho } \\
\text { que é por causa do } \\
\text { perfil, que não se } \\
\text { enquadravam." } \\
\text { "Durante o Pronatec } \\
\text { eu peguei os } \\
\text { conteúdos já } \\
\text { prontos." }\end{array}$ & $\begin{array}{l}\text { "Os gestores } \\
\text { tinham um } \\
\text { acordo com o } \\
\text { ministério de } \\
\text { acompanhar } \\
\text { visitando } \\
\text { algumas } \\
\text { turmas". } \\
\text { "Todos os } \\
\text { conteúdos tinha } \\
\text { a ver com o } \\
\text { social. Como } \\
\text { você deve } \\
\text { recepcionar um } \\
\text { evento..." } \\
\text { "O legal do } \\
\text { Pronatec é que o } \\
\text { aluno só precisa } \\
\text { se deslocar e } \\
\text { sentar na } \\
\text { cadeira e ter } \\
\text { intenção de } \\
\text { aprender. } \\
\text { Porque eles } \\
\text { forneciam o } \\
\text { transporte, a } \\
\text { alimentação } \\
\text { através de } \\
\text { valores, em } \\
\text { alguns casos } \\
\text { camiseta e } \\
\text { material." }\end{array}$ & $\begin{array}{l}\text { "...deu uma } \\
\text { base de como } \\
\text { é que funciona } \\
\text { essa área de } \\
\text { eventos.” } \\
\text { "Eu não me } \\
\text { identifico mais. } \\
\text { Não sabe se } \\
\text { pretende } \\
\text { continuar na } \\
\text { áreas de } \\
\text { camareira." }\end{array}$ & $\begin{array}{l}\text { "Os cursos } \\
\text { estimularam a } \\
\text { continuidade } \\
\text { nos estudos } \\
\text { em várias } \\
\text { pessoas". } \\
\text { 'Aprendi certas } \\
\text { coisas que eu } \\
\text { não conhecia, } \\
\text { eu tenho uma } \\
\text { outra visão." } \\
\text { "Não havia } \\
\text { muito } \\
\text { interesse no } \\
\text { curso, muito } \\
\text { estavam ali } \\
\text { para receber o } \\
\text { dinheiro } \\
\text { financiado". } \\
\text { "Eu estava lá } \\
\text { com o objetivo } \\
\text { de adquirir } \\
\text { conhecimento. } \\
\text { " } \\
\text { "Sim, estou } \\
\text { fazendo esse } \\
\text { novo curso." }\end{array}$ & $\begin{array}{l}\text { "Eu acho que } \\
\text { deveria ser } \\
\text { maior pela } \\
\text { quantidade de } \\
\text { conteúdo que } \\
\text { era passado } \\
\text { todos os dias. } \\
\text { É muito } \\
\text { conteúdo. É } \\
\text { muita } \\
\text { informação } \\
\text { para pouco } \\
\text { tempo." }\end{array}$ \\
\hline
\end{tabular}

3 egressos: ensino superior incompleto e 1 ensino superior em pedagogia, apenas 1 trabalha 
Cuiabá - 4 entrevistas (egressos, e gestores do PRONATEC Turismo)

\begin{tabular}{|c|c|c|c|c|c|c|c|c|}
\hline \multicolumn{3}{|c|}{ CATEGORIAS A PRIORI } & \multicolumn{6}{|c|}{ CATEGORIAS MATERIALISMO HISTORICO-DIALETICO } \\
\hline Categorias & Concepções & Avanços & $\begin{array}{l}\text { Teoria } \\
\text { prática }\end{array}$ & $\begin{array}{l}\text { Totalidade } \\
\text { fragmentação }\end{array}$ & $\begin{array}{l}\text { Contradição } \\
\text { mediação }\end{array}$ & $\begin{array}{l}\text { Subjetividade } \\
\text { objetividade }\end{array}$ & $\begin{array}{l}\text { Autonomia } \\
\text { dependência }\end{array}$ & $\begin{array}{l}\text { Criticidade } \\
\text { alienação }\end{array}$ \\
\hline $\begin{array}{l}\text { Inclusão social: } \\
\text { a inclusão dos } \\
\text { sujeitos é } \\
\text { determinante para } \\
\text { uma vida ativa e o } \\
\text { equilíbrio das } \\
\text { oportunidades em } \\
\text { sociedade, } \\
\text { considerando que } \\
\text { essa inclusão } \\
\text { prioritariamente } \\
\text { começa pelo acesso } \\
\text { ao emprego } \\
\text { qualificante, } \\
\text { possibilitador do } \\
\text { crescimento } \\
\text { profissional, espaço } \\
\text { onde o trabalhador } \\
\text { possa criar, } \\
\text { desenvolver-se e ter } \\
\text { suas individualidades } \\
\text { respeitadas. Acesso } \\
\text { aos direitos sociais, } \\
\text { políticos, civis, } \\
\text { econômicos, } \\
\text { culturais e ao lazer. }\end{array}$ & $\begin{array}{l}\text { "Financeirament } \\
\text { e não alterou } \\
\text { tanto o patamar, } \\
\text { mas } \\
\text { socialmente foi } \\
\text { relevante". } \\
\text { "eu acho que o } \\
\text { pronatec foi } \\
\text { importante, foi } \\
\text { um avanço e a } \\
\text { capacitação } \\
\text { continua sendo } \\
\text { uma grande } \\
\text { necessidade } \\
\text { pros } \\
\text { municípios". } \\
\text { "Nós temos que } \\
\text { treinar as } \\
\text { pessoas, nós } \\
\text { temos que } \\
\text { aplicar cursos } \\
\text { de qualificação } \\
\text { que é para as } \\
\text { pessoas } \\
\text { poderem estar } \\
\text { fazendo esse } \\
\text { atendimento". }\end{array}$ & $\begin{array}{l}\text { “...mas para } \\
\text { nós é muito } \\
\text { importante, } \\
\text { no caso, } \\
\text { estar } \\
\text { envolvendo a } \\
\text { comunidade } \\
\text { para estar } \\
\text { fazendo a } \\
\text { qualificação." }\end{array}$ & $\begin{array}{l}\text { "Conteúdo } \\
\text { programático } \\
\text { baseado em } \\
\text { aula técnicas } \\
\text { temáticas } \\
\text { específicas } \\
\text { nos diferentes } \\
\text { tipos de } \\
\text { eventos." } \\
\text { "Começamos } \\
\text { em } 20 \text { ou } 25 \text { e } \\
\text { terminamos } \\
\text { em } 13, \text { muita } \\
\text { gente desistiu } \\
\text { porque não } \\
\text { gostaram ou } \\
\text { porque } \\
\text { apareceu } \\
\text { outra coisa". } \\
\text { "Nós tivemos } \\
\text { aula prática, } \\
\text { como eu } \\
\text { disse, dentro } \\
\text { de hotéis, } \\
\text { fizemos } \\
\text { simulados de } \\
\text { como fazer um } \\
\text { casamento } \\
\text { assim uma } \\
\text { base bem } \\
\text { ampla." }\end{array}$ & $\begin{array}{l}\text { "Sim, aprendi bem } \\
\text { apesar do } \\
\text { cansaço, as aulas } \\
\text { eram após a } \\
\text { jornada de } \\
\text { trabalho". } \\
\text { "A maioria dos } \\
\text { alunos era de } \\
\text { baixa renda e de } \\
\text { periferia, logo, } \\
\text { teoricamente a } \\
\text { formação pode } \\
\text { gerar inclusão, o } \\
\text { que poderia } \\
\text { impactar na } \\
\text { qualidade de vida } \\
\text { local". } \\
\text { "as possibilidades } \\
\text { de estágio deixam } \\
\text { a desejar". } \\
\text { "A população da } \\
\text { Chapada não é } \\
\text { muito aberta, não } \\
\text { para trabalhar com } \\
\text { turismo não, por } \\
\text { isso que temos } \\
\text { que fazer primeiro } \\
\text { uma chamada". }\end{array}$ & $\begin{array}{l}\text { "atualmente } \\
\text { está } \\
\text { desempregada } \\
. " \\
\text { "Pelo menos } \\
\text { metade dos } \\
\text { alunos (do } \\
\text { inglês } \\
\text { instrumental) } \\
\text { era de } \\
\text { funcionários de } \\
\text { hotéis". } \\
\text { "Na verdade se } \\
\text { trabalho com a } \\
\text { demanda dos } \\
\text { munícipios, a } \\
\text { maioria das } \\
\text { vezes, com } \\
\text { algumas, } \\
\text { vamos dizer } \\
\text { assim, não é } \\
\text { imposição, por } \\
\text { que as vezes } \\
\text { acaba sendo } \\
\text { equivocado." }\end{array}$ & $\begin{array}{l}\text { "Atuou por } 6 \\
\text { anos. } \\
\text { Atualmente é } \\
\text { costureira." } \\
\text { "A gente não } \\
\text { pode afirmar } \\
\text { tanto assim } \\
\text { [cursos } \\
\text { influenciaram as } \\
\text { pessoas a fazer } \\
\text { outros]. Eu creio } \\
\text { que } \\
\text { automaticament } \\
\text { e isso vai, né, } \\
\text { porque o } \\
\text { turismo, as } \\
\text { pessoas que } \\
\text { trabalham no } \\
\text { turismo tem } \\
\text { uma exigência } \\
\text { por algo mais } \\
\text { qualificado e ele } \\
\text { acaba } \\
\text { provocando isso } \\
\text { nas pessoas, a } \\
\text { necessidade de } \\
\text { ter mais } \\
\text { conhecimento." }\end{array}$ & $\begin{array}{l}\text { "Sim, mas ainda } \\
\text { não é suficiente } \\
\text { para realizar } \\
\text { seu sonho de } \\
\text { ser governanta, } \\
\text { tem interesse } \\
\text { em novos } \\
\text { cursos". } \\
\text { "Sim, tudo que } \\
\text { for possível na } \\
\text { área de } \\
\text { hotelaria." } \\
\text { "galga } \\
\text { crescimento, } \\
\text { mas } \\
\text { condicionado a } \\
\text { outros cursos } \\
\text { complementares } \\
\text { de capacitação." }\end{array}$ & \\
\hline
\end{tabular}




\begin{tabular}{|c|c|c|c|c|c|c|c|c|}
\hline \multicolumn{3}{|c|}{ CATEGORIAS A PRIORI } & \multicolumn{6}{|c|}{ CATEGORIAS MATERIALISMO HISTORICO-DIALETICO } \\
\hline Categorias & Concepções & Avanços & $\begin{array}{l}\text { Teoria } \\
\text { prática }\end{array}$ & $\begin{array}{l}\text { Totalidade } \\
\text { fragmentação }\end{array}$ & $\begin{array}{l}\text { Contradição } \\
\text { mediação }\end{array}$ & $\begin{array}{l}\text { Subjetividade } \\
\text { objetividade }\end{array}$ & $\begin{array}{l}\text { Autonomia } \\
\text { dependência }\end{array}$ & $\begin{array}{l}\text { Criticidade } \\
\text { alienação }\end{array}$ \\
\hline $\begin{array}{l}\text { Desenvolvimento } \\
\text { humano/ } \\
\text { Cidadania } \\
\text { E intrínseco ao } \\
\text { desenvolvimento } \\
\text { humano a cidadania } \\
\text { que pressupõe } \\
\text { equidade de } \\
\text { oportunidades. } \\
\text { Tais como ingresso } \\
\text { ao trabalho digno, } \\
\text { acesso à } \\
\text { aposentadoria, à } \\
\text { segurança, à } \\
\text { habitação, à } \\
\text { educação, ao direito, } \\
\text { à cultura e ao lazer, } \\
\text { fatores essenciais } \\
\text { para a consolidação } \\
\text { da cidadania. E } \\
\text { requisitos para o } \\
\text { desenvolvimento } \\
\text { humano, assim como } \\
\text { a educação integral } \\
\text { dos sujeitos, que } \\
\text { tenha como objetivo } \\
\text { a cidadania, a } \\
\text { liberdade, a } \\
\text { autonomia e a } \\
\text { emancipação. }\end{array}$ & $\begin{array}{l}\text { "em questão } \\
\text { de cidadania, } \\
\text { ele foi muito } \\
\text { válido, } \\
\text { porque } \\
\text { através dele } \\
\text { eu conheci } \\
\text { muitas } \\
\text { pessoas". }\end{array}$ & $\begin{array}{l}\text { É questão de } \\
\text { visão, da cultura } \\
\text { dos povos. As } \\
\text { vezes a gente } \\
\text { tem que } \\
\text { interferir, eu } \\
\text { trabalho muito } \\
\text { com o turismo } \\
\text { criativo, turismo } \\
\text { solidário, com } \\
\text { os quilombolas } \\
\text { e os indígenas. } \\
\text { Acho que a } \\
\text { mentalidade vai } \\
\text { mudando, mas } \\
\text { tem que criar } \\
\text { uma } \\
\text { interferência } \\
\text { muito grande do } \\
\text { técnico, do } \\
\text { mobilizador, do } \\
\text { articulador, né, } \\
\text { até você } \\
\text { conseguir } \\
\text { formar as vezes } \\
\text { uma liderança e } \\
\text { essa liderança } \\
\text { que vai começar } \\
\text { a transferir a } \\
\text { confiança para } \\
\text { esses povos. }\end{array}$ & $\begin{array}{l}\text { "Poderia ter } \\
\text { mais uns } \\
\text { dois meses." } \\
\text { "teve } \\
\text { problema, } \\
\text { assim, dessa } \\
\text { evasão...a } \\
\text { gente teve } \\
\text { caso aqui de } \\
\text { não } \\
\text { conseguir } \\
\text { formar a } \\
\text { turma." }\end{array}$ & $\begin{array}{l}\text { "Muitos } \\
\text { desistiram } \\
\text { porque não } \\
\text { gostaram." } \\
\text { "a qualificação } \\
\text { tem que existir } \\
\text { aqui de várias } \\
\text { formas: } \\
\text { palestras, } \\
\text { treinamentos, } \\
\text { cursos." }\end{array}$ & $\begin{array}{l}\text { "Apesar dos cursos } \\
\text { atenderem a } \\
\text { necessidades } \\
\text { específicas a ordem } \\
\text { deixou um pouco a } \\
\text { desejar. Não } \\
\text { [começam pelo } \\
\text { atendimento] porque a } \\
\text { demanda, as vezes, é } \\
\text { meio equivocada. } \\
\text { Atendimento ao cliente } \\
\text { viria até antes de } \\
\text { cursos de língua, de } \\
\text { idiomas. As vezes o } \\
\text { município vê que as } \\
\text { pessoas não sabem } \\
\text { falar inglês ou } \\
\text { espanhol, mas ele não } \\
\text { teve um treinamento } \\
\text { básico, como abordar } \\
\text { o cliente." }\end{array}$ & $\begin{array}{l}\text { "Mas a gente } \\
\text { precisa } \\
\text { trabalhar aqui } \\
\text { os municípios } \\
\text { turísticos do } \\
\text { Pantanal, mas } \\
\text { a gente tem } \\
\text { dificuldade } \\
\text { com relação } \\
\text { as pessoas, } \\
\text { ao pessoal, } \\
\text { com aquela } \\
\text { mentalidade } \\
\text { do tradicional, } \\
\text { do ribeirinho." }\end{array}$ & & \\
\hline
\end{tabular}


Belo Horizonte - 10 entrevistas (egressos, gestores do PRONATEC Turismo)

\begin{tabular}{|c|c|c|c|c|c|c|c|c|}
\hline \multicolumn{3}{|c|}{ CATEGORIAS A PRIORI } & \multicolumn{6}{|c|}{ CATEGORIAS MATERIALISMO HISTORICO-DIALETICO } \\
\hline Categorias & Concepções & Avanços & $\begin{array}{l}\text { Teoria } \\
\text { prática }\end{array}$ & $\begin{array}{c}\text { Totalidade } \\
\text { fragmentação }\end{array}$ & $\begin{array}{c}\text { Contradição } \\
\text { mediação }\end{array}$ & $\begin{array}{c}\text { Subjetividade } \\
\text { objetividade }\end{array}$ & $\begin{array}{c}\text { Autonomia } \\
\text { dependência }\end{array}$ & $\begin{array}{l}\text { Criticidade } \\
\text { alienação }\end{array}$ \\
\hline $\begin{array}{l}\text { Inclusão social: } \\
\text { a inclusão dos } \\
\text { sujeitos é } \\
\text { determinante para } \\
\text { uma vida ativa e o } \\
\text { equilíbrio das } \\
\text { oportunidades em } \\
\text { sociedade, } \\
\text { considerando que } \\
\text { essa inclusão } \\
\text { prioritariamente } \\
\text { começa pelo } \\
\text { acesso ao emprego } \\
\text { qualificante, } \\
\text { possibilitador do } \\
\text { crescimento } \\
\text { profissional, espaço } \\
\text { onde o trabalhador } \\
\text { possa criar, } \\
\text { desenvolver-se e } \\
\text { ter suas } \\
\text { individualidades } \\
\text { respeitadas. } \\
\text { Acesso aos direitos } \\
\text { sociais, políticos, } \\
\text { civis, econômicos, } \\
\text { culturais e ao lazer. }\end{array}$ & $\begin{array}{l}\text { "Acredito que } \\
\text { o profissional } \\
\text { engajado, } \\
\text { capacitado e } \\
\text { atento estará } \\
\text { próximo ao } \\
\text { crescimento } \\
\text { profissional" } \\
\text { "Elevação da } \\
\text { empregabilid } \\
\text { ade" }\end{array}$ & & $\begin{array}{l}\text { "Inserção de } \\
\text { grupos } \\
\text { menos } \\
\text { favorecidos } \\
\text { na } \\
\text { qualificação } \\
\text { para a } \\
\text { empregabilid } \\
\text { ade". } \\
\text { "não temos } \\
\text { estatísticas, } \\
\text { somente } \\
\text { relatos de } \\
\text { empresas } \\
\text { que davam } \\
\text { preferencia } \\
\text { para } \\
\text { egressos..." }\end{array}$ & $\begin{array}{l}\text { "Conclui o curso } \\
\text { superior em turismo, } \\
\text { não encontrei } \\
\text { oportunidades de } \\
\text { emprego na área." } \\
\text { "As condições de } \\
\text { trabalho na área } \\
\text { possibilitam conhecer } \\
\text { pessoas, podendo } \\
\text { assim enriquecer o } \\
\text { crescimento } \\
\text { profissional, quanto } \\
\text { pessoal..". }\end{array}$ & $\begin{array}{l}\text { "Não foi minha } \\
\text { escolha } \\
\text { profissional, } \\
\text { apenas uma } \\
\text { forma de } \\
\text { pagar a } \\
\text { faculdade de } \\
\text { engenharia". } \\
\text { "A Unidade } \\
\text { Rede de } \\
\text { carreiras e um } \\
\text { departamento } \\
\text { do Senac que } \\
\text { procura fazer } \\
\text { a ponte do } \\
\text { egresso com o } \\
\text { mercado..., } \\
\text { Contudo não } \\
\text { temos } \\
\text { informações, } \\
\text { ainda, acerca } \\
\text { da condição } \\
\text { atual do } \\
\text { egresso no } \\
\text { mercado de } \\
\text { trabalho". }\end{array}$ & $\begin{array}{l}\text { "E uma profissão } \\
\text { que não vale } \\
\text { muito a pena". } \\
\text { "Trabalho em } \\
\text { outra área, mas } \\
\text { tenho interesse } \\
\text { me trabalhar } \\
\text { com turismo". } \\
\text { "Minha formação } \\
\text { educacional teve } \\
\text { pouca } \\
\text { importância e } \\
\text { não influenciou } \\
\text { na minha vida } \\
\text { profissional”. }\end{array}$ & $\begin{array}{l}\text { "A falta de } \\
\text { oportunidade e } \\
\text { retorno } \\
\text { financeiro da } \\
\text { área de } \\
\text { turismo me } \\
\text { manteve no } \\
\text { emprego que } \\
\text { possuía". } \\
\text { "Empresas do } \\
\text { ramo preferem } \\
\text { pessoas não } \\
\text { qualificadas, } \\
\text { pois não } \\
\text { ofertam bons } \\
\text { salários.". }\end{array}$ & $\begin{array}{l}\text { "a política foi } \\
\text { positiva, mas } \\
\text { deficiente } \\
\text { quanto à } \\
\text { operacionaliza } \\
\text { ção." } \\
\text { "faltou um } \\
\text { mecanismo do } \\
\text { programa de } \\
\text { atuação junto } \\
\text { aos possíveis } \\
\text { empregadores } \\
. " \\
\text { "alguns alunos } \\
\text { frequentavam } \\
\text { os cursos } \\
\text { somente para } \\
\text { garantias do } \\
\text { seguro } \\
\text { desemprego.. } \\
\text { demonstravam } \\
\text { pouco ou } \\
\text { nenhum } \\
\text { interesse para } \\
\text { o curso". }\end{array}$ \\
\hline
\end{tabular}




\begin{tabular}{|c|c|c|c|c|c|c|c|c|}
\hline \multicolumn{3}{|c|}{ CATEGORIAS A PRIORI } & \multicolumn{6}{|c|}{ CATEGORIAS MATERIALISMO HISTORICO-DIALETICO } \\
\hline Categorias & Concepções & Avanços & $\begin{array}{l}\text { Teoria } \\
\text { prática }\end{array}$ & $\begin{array}{l}\text { Totalidade } \\
\text { fragmentação }\end{array}$ & $\begin{array}{l}\text { Contradição } \\
\text { mediação }\end{array}$ & $\begin{array}{l}\text { Subjetividade } \\
\text { objetividade }\end{array}$ & $\begin{array}{l}\text { Autonomia } \\
\text { dependência }\end{array}$ & $\begin{array}{l}\text { Criticidade } \\
\text { alienação }\end{array}$ \\
\hline $\begin{array}{l}\text { Desenvolvimento } \\
\text { humano } \\
\text { Cidadania } \\
\text { E intrínseco ao } \\
\text { desenvolvimento } \\
\text { humano a } \\
\text { cidadania que } \\
\text { pressupõe } \\
\text { equidade de } \\
\text { oportunidades. } \\
\text { Tais como ingresso } \\
\text { ao trabalho digno, } \\
\text { acesso à } \\
\text { aposentadoria, à } \\
\text { segurança, à } \\
\text { habitação, à } \\
\text { educação, ao } \\
\text { direito, à cultura e } \\
\text { ao lazer, fatores } \\
\text { essenciais para a } \\
\text { consolidação da } \\
\text { cidadania. E } \\
\text { requisitos para o } \\
\text { desenvolvimento } \\
\text { humano, assim } \\
\text { como a educação } \\
\text { integral dos } \\
\text { sujeitos, que tenha } \\
\text { como objetivo a } \\
\text { cidadania, a } \\
\text { liberdade, a } \\
\text { autonomia e a } \\
\text { emancipação. }\end{array}$ & $\begin{array}{l}\text { "Minha } \\
\text { cidadania } \\
\text { não e } \\
\text { plenamente } \\
\text { exercida". } \\
\text { "a minha } \\
\text { condição de } \\
\text { cidadania e } \\
\text { ruim". } \\
\text { "condição de } \\
\text { cidadania e } \\
\text { regular" } \\
\text { "condição de } \\
\text { cidadania e } \\
\text { boa". }\end{array}$ & $\begin{array}{l}\text { "preciso de } \\
\text { novas } \\
\text { oportunidades } \\
\text { para continuar } \\
\text { aprimorando". } \\
\text { "a qualificação } \\
\text { e importante, } \\
\text { pois ela } \\
\text { fundamenta } \\
\text { não somente o } \\
\text { bom } \\
\text { atendimento } \\
\text { nas ACT's, } \\
\text { mas serve } \\
\text { como } \\
\text { possibilidade } \\
\text { de ampliação } \\
\text { de } \\
\text { oportunidades } \\
\text { dos sujeitos } \\
\text { ocupados". }\end{array}$ & $\begin{array}{l}\text { "acredito que } \\
\text { um curso na } \\
\text { área deveria } \\
\text { ter mais } \\
\text { horas } \\
\text { praticas... } \\
\text { nossa turma } \\
\text { não pode } \\
\text { utilizar o } \\
\text { restaurante } \\
\text { escola". } \\
\text { "os } \\
\text { professores } \\
\text { deveriam } \\
\text { utilizar uma } \\
\text { linguagem } \\
\text { mais próxima } \\
\text { a realidade } \\
\text { do aluno". } \\
\text { "minha turma } \\
\text { começou } \\
\text { com 30 } \\
\text { alunos e } \\
\text { formaram } \\
12 " .\end{array}$ & $\begin{array}{l}\text { "O Senac possui } \\
\text { instrumentalização } \\
\text { padronizada em todo o } \\
\text { Pais...um conjunto de } \\
\text { princípios deve estar } \\
\text { presente na formação } \\
\text { para distinguir os } \\
\text { alunos no mercado de } \\
\text { trabalho, envolvendo } \\
\text { cidadania, meio } \\
\text { ambiente, } \\
\text { empreendedorismo. O } \\
\text { foco e no } \\
\text { desenvolvimento de } \\
\text { competências, } \\
\text { divididos em } \\
\text { conhecimento, } \\
\text { habilidades e atitudes." }\end{array}$ & $\begin{array}{l}\text { "o curso foi } \\
\text { bom não só } \\
\text { para questão } \\
\text { profissional, } \\
\text { mas também } \\
\text { para pessoal" } \\
\text { (não trabalha). }\end{array}$ & $\begin{array}{l}\text { "a escolha do } \\
\text { curso se deu } \\
\text { pela } \\
\text { oportunidade de } \\
\text { vagas". (inglês) } \\
\text { "geralmente as } \\
\text { pessoas não se } \\
\text { importam com a } \\
\text { formação, uns } \\
\text { vieram pela } \\
\text { bolsa, outros } \\
\text { vieram pela } \\
\text { gratuidade. } \\
\text { Alguns vieram } \\
\text { pela } \\
\text { obrigatoriedade } \\
\text { do seguro } \\
\text { desemprego, se } \\
\text { interessaram } \\
\text { pela área e } \\
\text { investiam em } \\
\text { outros cursos } \\
\text { posteriormente." }\end{array}$ & $\begin{array}{l}\text { "trabalhei para } \\
\text { uma empresa } \\
\text { no setor } \\
\text { durante a copa } \\
\text { do mundo de } \\
2014 \text { ". } \\
\text { "estou fazendo } \\
\text { graduação em } \\
\text { administração } \\
\text { de empresas". } \\
\text { "comecei a } \\
\text { cursar } \\
\text { engenharia, } \\
\text { mas parei por } \\
\text { falta de } \\
\text { verbas." }\end{array}$ & $\begin{array}{l}\text { "Carga de } \\
\text { trabalho muito } \\
\text { extensa". } \\
\text { "a carga hora } \\
\text { dos cursos e } \\
\text { ruim". } \\
\text { "Ao final do } \\
\text { curso tivemos } \\
\text { uma atividade } \\
\text { pratica, mas } \\
\text { não acho que } \\
\text { tenha gerado } \\
\text { desafios } \\
\text { suficientes". } \\
\text { "falta de } \\
\text { seleção do } \\
\text { candidato." }\end{array}$ \\
\hline
\end{tabular}

Observação: 3 trabalham (1 como freelance) escolaridade: Superior incompleto 2, Superior 4, Pós-graduação 2 
São Paulo: 4 entrevistas (gestores e professores do PRONATEC Turismo)

\begin{tabular}{|c|c|c|c|c|c|c|c|c|}
\hline \multicolumn{3}{|c|}{ CATEGORIAS A PRIORI } & \multicolumn{6}{|c|}{ CATEGORIAS MATERIALISMO HISTORICO-DIALETICO } \\
\hline Categorias & Concepções & Avanços & $\begin{array}{l}\text { Teoria } \\
\text { prática }\end{array}$ & $\begin{array}{c}\text { Totalidade } \\
\text { fragmentação }\end{array}$ & $\begin{array}{l}\text { Contradição } \\
\text { mediação }\end{array}$ & $\begin{array}{c}\text { Subjetividade } \\
\text { objetividade }\end{array}$ & $\begin{array}{c}\text { Autonomia } \\
\text { dependência }\end{array}$ & $\begin{array}{l}\text { Criticidade } \\
\text { alienação }\end{array}$ \\
\hline $\begin{array}{l}\text { Inclusão social: } \\
\text { a inclusão dos } \\
\text { sujeitos é } \\
\text { determinante para } \\
\text { uma vida ativa e o } \\
\text { equilíbrio das } \\
\text { oportunidades em } \\
\text { sociedade, } \\
\text { considerando que } \\
\text { essa inclusão } \\
\text { prioritariamente } \\
\text { começa pelo } \\
\text { acesso ao emprego } \\
\text { qualificante, } \\
\text { possibilitador do } \\
\text { crescimento } \\
\text { profissional, espaço } \\
\text { onde o trabalhador } \\
\text { possa criar, } \\
\text { desenvolver-se e } \\
\text { ter suas } \\
\text { individualidades } \\
\text { respeitadas. } \\
\text { Acesso aos direitos } \\
\text { sociais, políticos, } \\
\text { civis, econômicos, } \\
\text { culturais e ao lazer. }\end{array}$ & $\begin{array}{l}\text { "Participação } \\
\text { dos alunos e } \\
\text { instituições } \\
\text { para } \\
\text { fomentar o } \\
\text { turismo } \\
\text { através da } \\
\text { qualificação. } \\
\text { Além disso, o } \\
\text { modelo do } \\
\text { Pronatec } \\
\text { Copa na } \\
\text { Empresa } \\
\text { possibilitou } \\
\text { que os } \\
\text { trabalhadore } \\
\text { s que } \\
\text { estavam } \\
\text { atuando no } \\
\text { setor } \\
\text { pudessem se } \\
\text { qualificar e } \\
\text { desenvolver } \\
\text { sua atuação } \\
\text { profissional, } \\
\text { melhorando } \\
\text { a qualidade } \\
\text { dos serviços } \\
\text { prestados } \\
\text { nessas } \\
\text { localidades e } \\
\text { empresas." }\end{array}$ & $\begin{array}{l}\text { Poderia ter } \\
\text { ocorrido } \\
\text { "Acompanhame } \\
\text { nto das políticas } \\
\text { públicas para o } \\
\text { aluno, com } \\
\text { plano de } \\
\text { ingresso e } \\
\text { mobilidade } \\
\text { profissional". }\end{array}$ & $\begin{array}{l}\text { "Os cursos } \\
\text { ofertados } \\
\text { nesses } \\
\text { programas } \\
\text { eram cursos } \\
\text { do catálogo } \\
\text { do Senac e } \\
\text { que seguem } \\
\text { as } \\
\text { premissas, } \\
\text { orientações e } \\
\text { catálogo do } \\
\text { MEC, bem } \\
\text { como os } \\
\text { critérios } \\
\text { pedagógicos } \\
\text { da } \\
\text { instituição." } \\
\text { "Todos os } \\
\text { cursos } \\
\text { ofertados } \\
\text { são } \\
\text { realizados } \\
\text { com base na } \\
\text { demanda de } \\
\text { formação } \\
\text { profissional } \\
\text { do mercado } \\
\text { de trabalho." }\end{array}$ & $\begin{array}{l}\text { "A didática precisava ser } \\
\text { a mais abrangente } \\
\text { possível, tendo em vista } \\
\text { que estávamos lidando } \\
\text { com turmas altamente } \\
\text { heterogêneas, com } \\
\text { alunos que, muitas } \\
\text { vezes, mal tinham } \\
\text { conhecimento de sua } \\
\text { própria língua nativa". }\end{array}$ & & $\begin{array}{l}\text { "O elevado } \\
\text { número de } \\
\text { evadidos dá-se, } \\
\text { em sua maioria, } \\
\text { por conta de } \\
\text { trabalho. Os } \\
\text { alunos, } \\
\text { normalmente, } \\
\text { participavam das } \\
\text { aulas dentro de } \\
\text { seus horários de } \\
\text { trabalho. } \\
\text { Diversas vezes } \\
\text { eles precisavam } \\
\text { ausentar-se das } \\
\text { aulas. Com as } \\
\text { faltas, os alunos } \\
\text { sentiam-se } \\
\text { desestimulados } \\
\text { e desistiam de } \\
\text { continuar." }\end{array}$ & & $\begin{array}{l}\text { "Dificuldade } \\
\text { com algumas } \\
\text { empresas, } \\
\text { falta de } \\
\text { interesse e/ou } \\
\text { não liberação } \\
\text { dos } \\
\text { funcionários } \\
\text { para o curso. } \\
\text { Além de } \\
\text { dificuldades e } \\
\text { intermitências } \\
\text { sistêmicas } \\
\text { (Sistec), para } \\
\text { efetivação do } \\
\text { processo de } \\
\text { registro e } \\
\text { regulatório do } \\
\text { programa." }\end{array}$ \\
\hline
\end{tabular}




\begin{tabular}{|c|c|c|c|c|c|c|c|c|}
\hline \multicolumn{3}{|c|}{ CATEGORIAS A PRIORI } & \multicolumn{6}{|c|}{ CATEGORIAS MATERIALISMO HISTORICO-DIALETICO } \\
\hline Categorias & Concepções & Avanços & Teoria/prática & $\begin{array}{l}\text { Totalidade/ } \\
\text { fragmentação }\end{array}$ & $\begin{array}{l}\text { Contradição } \\
\text { mediação }\end{array}$ & $\begin{array}{l}\text { Subjetividade } \\
\text { objetividade }\end{array}$ & $\begin{array}{l}\text { Autonomia } \\
\text { dependência }\end{array}$ & $\begin{array}{l}\text { Criticidade } \\
\text { alienação }\end{array}$ \\
\hline $\begin{array}{l}\text { Desenvolvimento } \\
\text { humano } \\
\text { Cidadania } \\
\text { E intrínseco ao } \\
\text { desenvolvimento } \\
\text { humano a } \\
\text { cidadania que } \\
\text { pressupõe } \\
\text { equidade de } \\
\text { oportunidades. } \\
\text { Tais como ingresso } \\
\text { ao trabalho digno, } \\
\text { acesso à } \\
\text { aposentadoria, à } \\
\text { segurança, à } \\
\text { habitação, à } \\
\text { educação, ao } \\
\text { direito, à cultura e } \\
\text { ao lazer, fatores } \\
\text { essenciais para a } \\
\text { consolidação da } \\
\text { cidadania. E } \\
\text { requisitos para o } \\
\text { desenvolvimento } \\
\text { humano, assim } \\
\text { como a educação } \\
\text { integral dos } \\
\text { sujeitos, que tenha } \\
\text { como objetivo a } \\
\text { cidadania, a } \\
\text { liberdade, a } \\
\text { autonomia e a } \\
\text { emancipação. }\end{array}$ & $\begin{array}{l}\text { Em todo o } \\
\text { processo de } \\
\text { formação } \\
\text { profissional } \\
\text { entendemos } \\
\text { que é } \\
\text { primordial } \\
\text { propiciar aos } \\
\text { alunos uma } \\
\text { oportunidade } \\
\text { para aprender } \\
\text { de maneira } \\
\text { criteriosa e } \\
\text { atuante, } \\
\text { exercendo na } \\
\text { prática os } \\
\text { conhecimento } \\
\text { s, habilidades } \\
\text { e valores } \\
\text { trabalhados ao } \\
\text { longo dos } \\
\text { cursos." }\end{array}$ & $\begin{array}{l}\text { "A parceria } \\
\text { estreita entre a } \\
\text { empresa em } \\
\text { que aconteceu } \\
\text { o curso, seu } \\
\text { entusiasmo } \\
\text { com a } \\
\text { oportunidade e } \\
\text { valorização do } \\
\text { programa se } \\
\text { refletiu no } \\
\text { desempenho } \\
\text { dos } \\
\text { colaboradores } \\
\text { e contribuiu } \\
\text { muito para o } \\
\text { sucesso da } \\
\text { turma em } \\
\text { questão." } \\
\text { "O contato } \\
\text { com } \\
\text { profissionais } \\
\text { da área me } \\
\text { permitiu } \\
\text { aprender as } \\
\text { necessidades } \\
\text { específicas } \\
\text { para atuação } \\
\text { nesse campo } \\
\text { e, a partir daí, } \\
\text { pude adequar } \\
\text { as aulas.". }\end{array}$ & $\begin{array}{l}\text { "Em relação às } \\
\text { evasões, parte } \\
\text { delas foram } \\
\text { justificadas pelo } \\
\text { público por falta } \\
\text { de interesse na } \\
\text { continuidade do } \\
\text { curso... mudança } \\
\text { de horário ou } \\
\text { local de trabalho." } \\
\text { “.... os fluxos de } \\
\text { encaminhamento } \\
\text { e matricula dos } \\
\text { alunos era } \\
\text { complexo e } \\
\text { dificultava, muitas } \\
\text { vezes, que o } \\
\text { aluno de } \\
\text { determinada } \\
\text { localidade } \\
\text { conseguisse fazer } \\
\text { o curso em sua } \\
\text { localidade, sendo } \\
\text { encaminhado } \\
\text { para participar de } \\
\text { cursos distantes } \\
\text { da residência." }\end{array}$ & $\begin{array}{l}\text { "houve casos de } \\
\text { empresas que } \\
\text { não se envolviam } \\
\text { muito ou não } \\
\text { proporcionava ao } \\
\text { colaborador as } \\
\text { condições } \\
\text { necessárias para } \\
\text { participar dos } \\
\text { cursos." }\end{array}$ & & $\begin{array}{l}\text { "Muitos faltavam } \\
\text { às aulas devido } \\
\text { a compromissos } \\
\text { no trabalho. } \\
\text { Nesses casos, } \\
\text { nem a empresa } \\
\text { priorizou a } \\
\text { presença do } \\
\text { aluno em sala". }\end{array}$ & $\begin{array}{l}\text { "A receptividade } \\
\text { das empresas foi } \\
\text { muito boa, e em } \\
\text { alguns casos, } \\
\text { havia mais } \\
\text { interessados do } \\
\text { que vagas." } \\
\text { "a formação } \\
\text { adquirida ajudou } \\
\text { os alunos a } \\
\text { serem mais } \\
\text { competitivos no } \\
\text { mercado de } \\
\text { trabalho. Muitos } \\
\text { seguiram seus } \\
\text { estudos no idioma } \\
\text {. }\end{array}$ & \\
\hline
\end{tabular}


Salvador 10 (egressos, gestores e professores do PRONATEC Turismo)

\begin{tabular}{|c|c|c|c|c|c|c|c|c|}
\hline \multicolumn{3}{|c|}{ CATEGORIAS A PRIORI } & \multicolumn{6}{|c|}{ CATEGORIAS MATERIALISMO HISTORICO-DIALETICO } \\
\hline Categorias & Concepções & Avanços & Teoria/prática & $\begin{array}{c}\text { Totalidade } \\
\text { fragmentação }\end{array}$ & $\begin{array}{c}\text { Contradição } \\
\text { mediação }\end{array}$ & $\begin{array}{c}\text { Subjetividade } \\
\text { objetividade }\end{array}$ & $\begin{array}{c}\text { Autonomia } \\
\text { dependência }\end{array}$ & $\begin{array}{l}\text { Criticidade } \\
\text { alienação }\end{array}$ \\
\hline $\begin{array}{l}\text { Inclusão social: } \\
\text { a inclusão dos } \\
\text { sujeitos é } \\
\text { determinante para } \\
\text { uma vida ativa e o } \\
\text { equilíbrio das } \\
\text { oportunidades em } \\
\text { sociedade, } \\
\text { considerando que } \\
\text { essa inclusão } \\
\text { prioritariamente } \\
\text { começa pelo } \\
\text { acesso ao emprego } \\
\text { qualificante, } \\
\text { possibilitador do } \\
\text { crescimento } \\
\text { profissional, espaço } \\
\text { onde o trabalhador } \\
\text { possa criar, } \\
\text { desenvolver-se e } \\
\text { ter suas } \\
\text { individualidades } \\
\text { respeitadas. } \\
\text { Acesso aos direitos } \\
\text { sociais, políticos, } \\
\text { civis, econômicos, } \\
\text { culturais e ao lazer. }\end{array}$ & $\begin{array}{l}\text { "os cursos } \\
\text { buscam melhorar } \\
\text { a qualificação das } \\
\text { pessoas para } \\
\text { buscarem a } \\
\text { empregabilidade." }\end{array}$ & $\begin{array}{l}\text { "O curso } \\
\text { possibilitou } \\
\text { ter uma } \\
\text { postura } \\
\text { profissional." } \\
\text { "poderia ter } \\
\text { tido maior } \\
\text { mobilização } \\
\text { entre os } \\
\text { atores } \\
\text { sociais." } \\
\text { "os cursos } \\
\text { deveriam ser } \\
\text { adaptados } \\
\text { ao perfil dos } \\
\text { alunos.. } \\
\text { sondagem } \\
\text { de onde se } \\
\text { encontram } \\
\text { os postos de } \\
\text { trabalho.. os } \\
\text { cursos } \\
\text { deveriam ser } \\
\text { mais } \\
\text { alinhados as } \\
\text { necessidade } \\
\text { s locais." }\end{array}$ & $\begin{array}{l}\text { "o setor e } \\
\text { dinâmico e } \\
\text { permite trabalho } \\
\text { em diversas } \\
\text { campos." } \\
\text { "buscou-se } \\
\text { atender as } \\
\text { necessidades do } \\
\text { mercado." } \\
\text { "o elevado } \\
\text { numero de } \\
\text { evadidos ocorreu } \\
\text { porque as } \\
\text { pessoas não } \\
\text { tinham } \\
\text { noção/orientação } \\
\text { quanto à escolha } \\
\text { do curso." } \\
\text { "uma qualificação } \\
\text { apenas não da } \\
\text { condições } \\
\text { efetivas para a } \\
\text { inserção no } \\
\text { mercado de } \\
\text { trabalho, e } \\
\text { preciso dar } \\
\text { continuidade na } \\
\text { educação formal." }\end{array}$ & $\begin{array}{l}\text { "O curso precisa } \\
\text { ter mais suporte } \\
\text { quanto a idiomas, } \\
\text { porque os hotéis } \\
\text { buscam pessoas } \\
\text { com essa } \\
\text { experiência." } \\
\text { "o curso } \\
\text { possibilitou o } \\
\text { aprendizado de } \\
\text { como trabalhar } \\
\text { em equipe, ter } \\
\text { comprometimento } \\
\text {, responsabilidade } \\
\text { e trato com o } \\
\text { outro." } \\
\text { " a minha } \\
\text { expectativa e que } \\
\text { o curso possa } \\
\text { mudar a vida das } \\
\text { pessoas, garantir } \\
\text { a } \\
\text { empregabilidade, } \\
\text { mas não sei se } \\
\text { isso ocorreu } \\
\text { efetivamente." } \\
\text { "o MEC deveria } \\
\text { direcionar os } \\
\text { conteúdos." }\end{array}$ & $\begin{array}{l}\text { "não houve } \\
\text { acompanhame } \\
\text { nto dos } \\
\text { egressos." } \\
\text { "informalmente } \\
\text { sabemos que } \\
\text { alguns alunos } \\
\text { conseguiram } \\
\text { trabalho na } \\
\text { área." } \\
\text { "o MEC não } \\
\text { orientou } \\
\text { quanto a } \\
\text { acompanhar } \\
\text { os egressos." } \\
\text { "Tentamos } \\
\text { parceria com o } \\
\text { SINE para que } \\
\text { os egressos } \\
\text { tivessem } \\
\text { preferencia, } \\
\text { mas não sei o } \\
\text { resultado." }\end{array}$ & $\begin{array}{l}\text { "a escolha do } \\
\text { curso se deu a } \\
\text { partir da } \\
\text { disponibilidade } \\
\text { da oferta". } \\
\text { "a grande } \\
\text { maioria não } \\
\text { estava } \\
\text { interessada no } \\
\text { curso." }\end{array}$ & $\begin{array}{l}\text { "não da total } \\
\text { segurança. } \\
\text { Porque alguns } \\
\text { assuntos eu } \\
\text { não tenho } \\
\text { domínio." } \\
\\
\text { "Consegui } \\
\text { estágio após o } \\
\text { curso e } \\
\text { trabalho } \\
\text { indiretamente } \\
\text { na área." } \\
\text { "foi possível } \\
\text { despertar para } \\
\text { a área de } \\
\text { turismo a partir } \\
\text { desse curso." } \\
\text { "quero } \\
\text { trabalhar } \\
\text { nessa área." } \\
\text { "necessidade } \\
\text { de parcerias } \\
\text { efetivas, } \\
\text { alinhamento } \\
\text { com a } \\
\text { realidade } \\
\text { local." }\end{array}$ & $\begin{array}{l}\text { "não se buscou } \\
\text { o mercado." } \\
\text { "os cursos são } \\
\text { feitos de acordo } \\
\text { com a demanda } \\
\text { do mercado." } \\
\text { "alguns cursos } \\
\text { eram solicitados } \\
\text { por estarem na } \\
\text { moda, mas } \\
\text { muitas vezes } \\
\text { não tinham } \\
\text { postos de } \\
\text { trabalho } \\
\text { compatíveis." }\end{array}$ \\
\hline
\end{tabular}




\begin{tabular}{|c|c|c|c|c|c|c|c|c|}
\hline \multicolumn{3}{|c|}{ CATEGORIAS A PRIORI } & \multicolumn{6}{|c|}{ CATEGORIAS MATERIALISMO HISTORICO-DIALETICO } \\
\hline Categorias & Concepções & Avanços & $\begin{array}{l}\text { Teoria } \\
\text { prática }\end{array}$ & $\begin{array}{l}\text { Totalidade } \\
\text { fragmentação }\end{array}$ & $\begin{array}{l}\text { Contradição } \\
\text { mediação }\end{array}$ & $\begin{array}{l}\text { Subjetividade } \\
\text { objetividade }\end{array}$ & $\begin{array}{l}\text { Autonomia } \\
\text { dependência }\end{array}$ & $\begin{array}{l}\text { Criticidade } \\
\text { alienação }\end{array}$ \\
\hline $\begin{array}{l}\text { Desenvolvimento } \\
\text { humano } \\
\text { Cidadania } \\
\text { E intrínseco ao } \\
\text { desenvolvimento } \\
\text { humano a } \\
\text { cidadania que } \\
\text { pressupõe } \\
\text { equidade de } \\
\text { oportunidades. } \\
\text { Tais como ingresso } \\
\text { ao trabalho digno, } \\
\text { acesso à } \\
\text { aposentadoria, à } \\
\text { segurança, à } \\
\text { habitação, à } \\
\text { educação, ao } \\
\text { direito, à cultura e } \\
\text { ao lazer, fatores } \\
\text { essenciais para a } \\
\text { consolidação da } \\
\text { cidadania. E } \\
\text { requisitos para o } \\
\text { desenvolvimento } \\
\text { humano, assim } \\
\text { como a educação } \\
\text { integral dos } \\
\text { sujeitos, que tenha } \\
\text { como objetivo a } \\
\text { cidadania, a } \\
\text { liberdade, a } \\
\text { autonomia e a } \\
\text { emancipação. }\end{array}$ & $\begin{array}{l}\text { Maior } \\
\text { preocupação } \\
\text { com as } \\
\text { questões do } \\
\text { bairro. } \\
\text { "saber meus } \\
\text { direitos e } \\
\text { deveres." } \\
\text { Não } \\
\text { reconhece seu } \\
\text { papel } \\
\text { enquanto } \\
\text { cidadã. } \\
\text { "A formação } \\
\text { possibilitou ter } \\
\text { novos } \\
\text { conhecimento } \\
\text { s, novos } \\
\text { horizontes e } \\
\text { reconhecer o } \\
\text { outro." } \\
\text { "a ação por si } \\
\text { só amplia os } \\
\text { horizontes dos } \\
\text { sujeitos." }\end{array}$ & $\begin{array}{l}\text { "os cursos } \\
\text { devem } \\
\text { primeiramente } \\
\text { formar pessoas } \\
\text { depois o } \\
\text { profissional." } \\
\text { "foi feito um } \\
\text { trabalho de } \\
\text { incentivo para } \\
\text { que os alunos } \\
\text { retornassem a } \\
\text { instituição para } \\
\text { continuidade } \\
\text { dos estudos na } \\
\text { educação } \\
\text { formal." } \\
\text { "deveria ter } \\
\text { ocorrido uma } \\
\text { pesquisa antes } \\
\text { com os } \\
\text { participantes } \\
\text { para verificar } \\
\text { suas } \\
\text { necessidades." } \\
\text { "as } \\
\text { metodologias } \\
\text { deveriam ser } \\
\text { adaptadas, ser } \\
\text { mais dinâmica, } \\
\text { lúdicas." }\end{array}$ & $\begin{array}{l}\text { "muitos } \\
\text { abandonaram o } \\
\text { curso por não se } \\
\text { identificar com a } \\
\text { área." } \\
\text { "não houve } \\
\text { adequação do } \\
\text { curso ao publico, } \\
\text { nem nivelamento } \\
\text { entre os } \\
\text { participantes." } \\
\text { "o curso permitiu a } \\
\text { ampliação da visão } \\
\text { dos sujeitos, a } \\
\text { redescoberta de } \\
\text { oportunidades e } \\
\text { possibilidade de } \\
\text { alcançarem seus } \\
\text { objetivos." } \\
\text { "a duração do } \\
\text { curso foi } \\
\text { insuficiente para } \\
\text { atender as } \\
\text { necessidades do } \\
\text { educando, } \\
\text { precisaria ter uma } \\
\text { ambientação, } \\
\text { nivelamento para } \\
\text { depois entrar nos } \\
\text { conteúdos básicos } \\
\text { e específicos". }\end{array}$ & $\begin{array}{l}\text { "A carga horaria } \\
\text { foi insuficiente } \\
\text { para ampliar o } \\
\text { campo de visão e } \\
\text { incluir horas para } \\
\text { idiomas." } \\
\text { "foi dado } \\
\text { flexibilidade para } \\
\text { se adaptar os } \\
\text { cursos a } \\
\text { realidade local." } \\
\text { "os cursos são } \\
\text { oportunidades } \\
\text { para as pessoas } \\
\text { de baixa renda, } \\
\text { baixo nível de } \\
\text { escolaridade se } \\
\text { inserir em um } \\
\text { processo de } \\
\text { qualificação e } \\
\text { conhecer seus } \\
\text { direitos em } \\
\text { participar de } \\
\text { atividades da } \\
\text { instituição." } \\
\text { "Foram } \\
\text { trabalhados } \\
\text { conteúdos de } \\
\text { ética, relações } \\
\text { humanas, } \\
\text { português e } \\
\text { matemática." }\end{array}$ & $\begin{array}{l}\text { "o sucesso do } \\
\text { programa se } \\
\text { deve ao peso da } \\
\text { instituição } \\
\text { ofertante do } \\
\text { curso, ao } \\
\text { comprometimen } \\
\text { to dos } \\
\text { professores e a } \\
\text { satisfação dos } \\
\text { alunos." } \\
\text { "muito fizeram o } \\
\text { curso pelo } \\
\text { auxilio do } \\
\text { governo."... } \\
\text { "desistiam do } \\
\text { curso pelo } \\
\text { atraso das } \\
\text { bolsas." } \\
\text { "e necessário } \\
\text { primeiramente } \\
\text { aprender a } \\
\text { aprender."... } \\
\text { "quem não } \\
\text { desenvolve } \\
\text { essa habilidade } \\
\text { não consegue } \\
\text { acompanhar o } \\
\text { curso." }\end{array}$ & $\begin{array}{l}\text { "por questões } \\
\text { financeiras tive } \\
\text { que abandonar } \\
\text { o curso que } \\
\text { ingressei após o } \\
\text { Pronatec.." }\end{array}$ & $\begin{array}{l}\text { O curso } \\
\text { possibilitou a } \\
\text { entrada no } \\
\text { curso de } \\
\text { tecnologia de } \\
\text { eventos no } \\
\text { IFBA. } \\
\text { "Após o } \\
\text { curso estou } \\
\text { fazendo } \\
\text { tecnologia } \\
\text { em eventos." } \\
\text { "voltei a } \\
\text { estudar no } \\
\text { IFBA, curso } \\
\text { tecnológico } \\
\text { em meios de } \\
\text { hospedagens } \\
. " \\
\text { "com a base } \\
\text { do curso } \\
\text { consegui } \\
\text { passar no } \\
\text { vestibular." }\end{array}$ & $\begin{array}{l}\text { "Ter mais } \\
\text { vivência, } \\
\text { equilibrar a } \\
\text { teoria com a } \\
\text { pratica." } \\
\text { "a carga } \\
\text { horaria foi } \\
\text { reduzida } \\
\text { para se obter } \\
\text { uma } \\
\text { qualificação } \\
\text { mais } \\
\text { consistente." } \\
\text { "o curso } \\
\text { deveria ser } \\
\text { melhor } \\
\text { elaborado, } \\
\text { traçar o perfil } \\
\text { adequado do } \\
\text { aluno e ter } \\
\text { um } \\
\text { nivelamento } \\
\text { de } \\
\text { escolaridade. } \\
\text { " }\end{array}$ \\
\hline
\end{tabular}




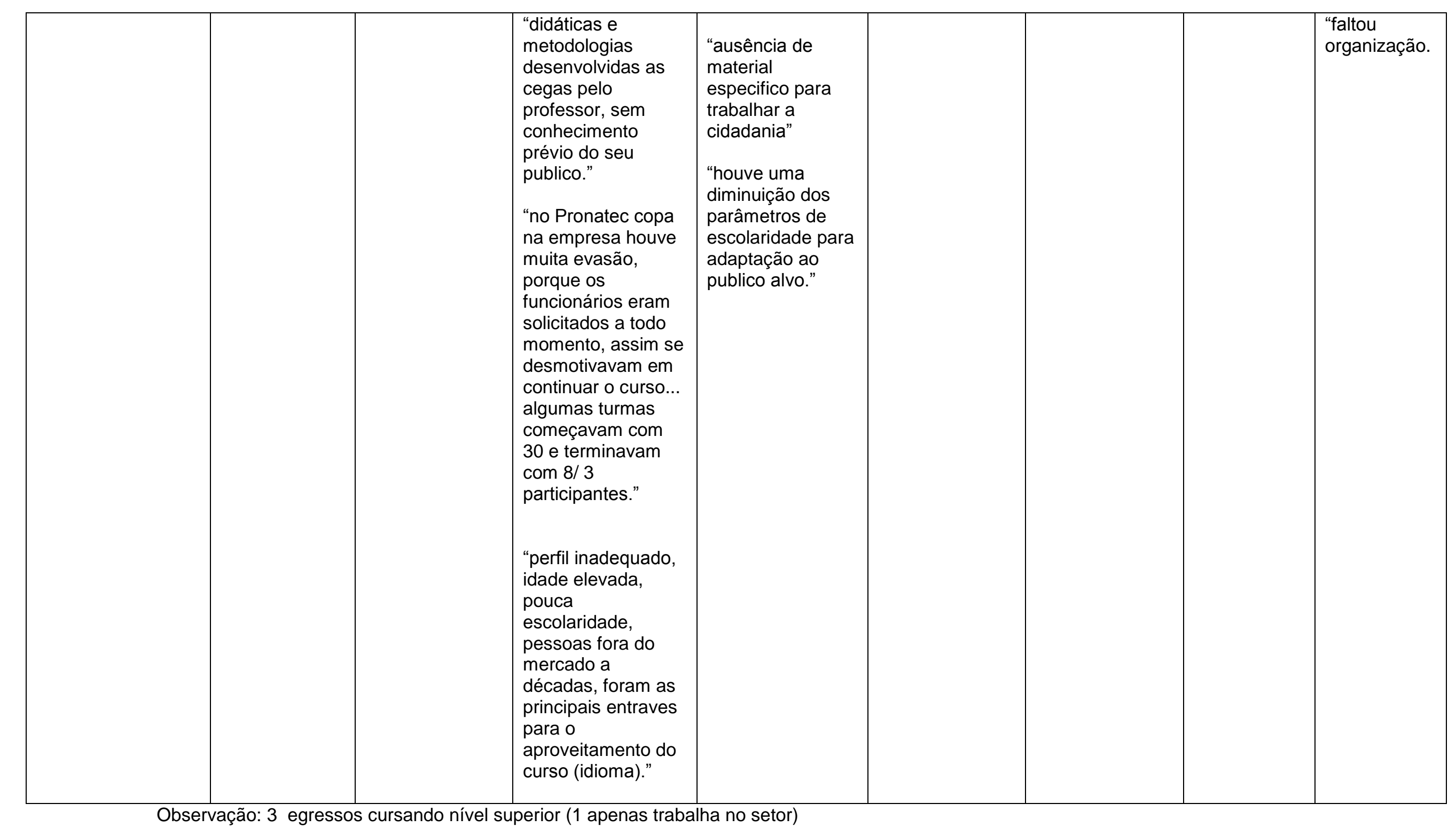


Porto Alegre - entrevistas 9 (egressos, gestores e instrutores do PRONATEC Turismo)

\begin{tabular}{|c|c|c|c|c|c|c|c|c|}
\hline \multicolumn{3}{|c|}{ CATEGORIAS A PRIORI } & \multicolumn{6}{|c|}{ CATEGORIAS MATERIALISMO HISTORICO-DIALETICO } \\
\hline Categorias & Concepções & Avanços & Teoria/prática & $\begin{array}{l}\text { Totalidade } \\
\text { fragmentação }\end{array}$ & $\begin{array}{l}\text { Contradição } \\
\text { mediação }\end{array}$ & $\begin{array}{l}\text { Subjetividade } \\
\text { objetividade }\end{array}$ & $\begin{array}{l}\text { Autonomia } \\
\text { dependência }\end{array}$ & $\begin{array}{l}\text { Criticidade } \\
\text { alienação }\end{array}$ \\
\hline $\begin{array}{l}\text { Inclusão social: } \\
\text { a inclusão dos } \\
\text { sujeitos é } \\
\text { determinante para } \\
\text { uma vida ativa e o } \\
\text { equilíbrio das } \\
\text { oportunidades em } \\
\text { sociedade, } \\
\text { considerando que } \\
\text { essa inclusão } \\
\text { prioritariamente } \\
\text { começa pelo acesso } \\
\text { ao emprego } \\
\text { qualificante, } \\
\text { possibilitador do } \\
\text { crescimento } \\
\text { profissional, espaço } \\
\text { onde o trabalhador } \\
\text { possa criar, } \\
\text { desenvolver-se e ter } \\
\text { suas individualidades } \\
\text { respeitadas. Acesso } \\
\text { aos direitos sociais, } \\
\text { políticos, civis, } \\
\text { econômicos, } \\
\text { culturais e ao lazer. }\end{array}$ & $\begin{array}{l}\text { "Educação } \\
\text { para formar o } \\
\text { trabalhador } \\
\text { precisa fugir } \\
\text { do modelo } \\
\text { "fastfood"... } \\
\text { muita pressão } \\
\text { dos } \\
\text { empregadores } \\
\text { que os cursos } \\
\text { eram longo. } \\
\text { Forma no } \\
\text { trabalho, } \\
\text { qualificação } \\
\text { continuada. } \\
\text { Não é possível } \\
\text { aprender tudo } \\
\text { em apenas um } \\
\text { curso." }\end{array}$ & $\begin{array}{l}\text { "A gente forma } \\
\text { em trabalho e } \\
\text { essa formação } \\
\text { precisa ser } \\
\text { contínua, pelo } \\
\text { simples fato } \\
\text { de que } \\
\text { ninguém } \\
\text { aprende tudo } \\
\text { de uma só } \\
\text { vez, porque o } \\
\text { conhecimento } \\
\text { vai o tempo } \\
\text { todo se } \\
\text { atualizando." } \\
\text { "Conversar } \\
\text { com as } \\
\text { lideranças } \\
\text { dentro da } \\
\text { comunidade } \\
\text { para estreitar } \\
\text { a necessidades. }\end{array}$ & $\begin{array}{l}\text { "não houve } \\
\text { planejamento } \\
\text { para } \\
\text { acompanhamen } \\
\text { to dos } \\
\text { egressos". } \\
\text { "As práticas } \\
\text { pedagógicas } \\
\text { eram de visitas } \\
\text { técnicas, } \\
\text { trabalhos que } \\
\text { aproximavam os } \\
\text { alunos do } \\
\text { mercado." } \\
\text { "Deveria ter sido } \\
\text { feito uma } \\
\text { pesquisa de } \\
\text { mercado para } \\
\text { identificar a } \\
\text { necessidade de } \\
\text { qualificação } \\
\text { para o Turismo, } \\
\text { faltou } \\
\text { articulação entre } \\
\text { o poder público } \\
\text { e a iniciativa } \\
\text { privada para } \\
\text { absorver os } \\
\text { egressos." }\end{array}$ & $\begin{array}{l}\text { "trade precisa de } \\
\text { apropriar." } \\
\text { "Formar no } \\
\text { horário de } \\
\text { trabalho - dentro } \\
\text { do local de } \\
\text { trabalho - } \\
\text { mediação entre } \\
\text { patrão e } \\
\text { funcionário." } \\
\text { "evasão devido à } \\
\text { falta de repasso } \\
\text { das bolsas." } \\
\text { "não houve } \\
\text { acompanhament } \\
\text { o dos egressos." }\end{array}$ & $\begin{array}{l}\text { "Há também um } \\
\text { certo impacto, } \\
\text { "nossa, é } \\
\text { verdade eu } \\
\text { preciso } \\
\text { qualificar", mas } \\
\text { na medida que } \\
\text { eu qualificar, o } \\
\text { sindicato vai me } \\
\text { dizer que eu } \\
\text { preciso receber } \\
\text { mais. Ele precisa } \\
\text { vir a receber } \\
\text { como garçom, } \\
\text { até então ele era } \\
\text { qualquer outra } \\
\text { coisa, um } \\
\text { atendente, acho } \\
\text { que tinha isso." } \\
\\
\text { "Acredita-se que } \\
\text { é necessário à } \\
\text { formação de } \\
\text { Agente de } \\
\text { Informações } \\
\text { Turísticas, mas } \\
\text { de fato não há } \\
\text { um mercado de } \\
\text { trabalho } \\
\text { especifico." }\end{array}$ & $\begin{array}{l}\text { “Acho que o } \\
\text { trade precisa } \\
\text { se apropriar } \\
\text { melhor do que } \\
\text { ele necessita e } \\
\text { de que isso } \\
\text { exige } \\
\text { investimento e } \\
\text { exige tempo". } \\
\text { “já me } \\
\text { disseram isso, } \\
\text { 'vou qualificar } \\
\text { pra ir embora? } \\
\text { Meu vizinho ali } \\
\text { pegar?' } \\
\text { restaurante } \\
\text { também pensa } \\
\text { assim. }\end{array}$ & $\begin{array}{l}\text { "As pessoas } \\
\text { prestam } \\
\text { serviço, } \\
\text { grande maioria } \\
\text { não tinha um } \\
\text { vínculo formal } \\
\text { de emprego." } \\
\text { "Muitos } \\
\text { aposentados } \\
\text { procurando } \\
\text { uma nova } \\
\text { forma de } \\
\text { ingressar no } \\
\text { mercado de } \\
\text { trabalho, viram } \\
\text { no turismo } \\
\text { uma fonte } \\
\text { preciosa de } \\
\text { divulgação e } \\
\text { de trabalho". } \\
\text { "Alguns alunos } \\
\text { conseguiram } \\
\text { empreender } \\
\text { após o curso, } \\
\text { e melhoram a } \\
\text { sua qualidade } \\
\text { de vida". }\end{array}$ & $\begin{array}{l}\text { "Faltou um } \\
\text { dialogo entre o } \\
\text { poder público, } \\
\text { iniciativa privada } \\
\text { e instituição de } \\
\text { ensino para que } \\
\text { os mesmo } \\
\text { pudessem } \\
\text { absorver os } \\
\text { egressos dos } \\
\text { cursos para o } \\
\text { mercado de } \\
\text { trabalho". } \\
\text { "Diagnostico: } \\
\text { penso que não } \\
\text { tenha ocorrido, } \\
\text { porque eu } \\
\text { acredito que se } \\
\text { isso de fato } \\
\text { tivesse ocorrido } \\
\text { não haveria } \\
\text { cursos assim } \\
\text { com essa } \\
\text { dificuldade de } \\
\text { fechamento de } \\
\text { turmas." }\end{array}$ \\
\hline
\end{tabular}




\begin{tabular}{|c|c|c|c|c|c|c|c|c|}
\hline \multicolumn{3}{|c|}{ CATEGORIAS A PRIORI } & \multicolumn{6}{|c|}{ CATEGORIAS MATERIALISMO HISTORICO-DIALETICO } \\
\hline Categorias & Concepções & Avanços & $\begin{array}{l}\text { Teoria } \\
\text { prática }\end{array}$ & $\begin{array}{l}\text { Totalidade } \\
\text { fragmentação }\end{array}$ & $\begin{array}{l}\text { Contradição } \\
\text { mediação }\end{array}$ & $\begin{array}{l}\text { Subjetividade } \\
\text { objetividade }\end{array}$ & $\begin{array}{l}\text { Autonomia } \\
\text { dependência }\end{array}$ & $\begin{array}{l}\text { Criticidade } \\
\text { alienação }\end{array}$ \\
\hline $\begin{array}{l}\text { Desenvolvimento } \\
\text { humano/ } \\
\text { Cidadania } \\
\text { E intrínseco ao } \\
\text { desenvolvimento } \\
\text { humano a cidadania } \\
\text { que pressupõe } \\
\text { equidade de } \\
\text { oportunidades. } \\
\text { Tais como ingresso } \\
\text { ao trabalho digno, } \\
\text { acesso à } \\
\text { aposentadoria, à } \\
\text { segurança, à } \\
\text { habitação, à } \\
\text { educação, ao direito, } \\
\text { à cultura e ao lazer, } \\
\text { fatores essenciais } \\
\text { para a consolidação } \\
\text { da cidadania. E } \\
\text { requisitos para o } \\
\text { desenvolvimento } \\
\text { humano, assim como } \\
\text { a educação integral } \\
\text { dos sujeitos, que } \\
\text { tenha como objetivo } \\
\text { a cidadania, a } \\
\text { liberdade, a } \\
\text { autonomia e a } \\
\text { emancipação. }\end{array}$ & $\begin{array}{l}\text { "cursos } \\
\text { deveriam ser } \\
\text { mais } \\
\text { completos, } \\
\text { cidadania } \\
\text { atender } \\
\text { diferentes } \\
\text { públicos." } \\
\text { "A leitura que } \\
\text { eu faço: esses } \\
\text { cursos } \\
\text { impulsiona a } \\
\text { buscar } \\
\text { qualificação no } \\
\text { sentido de } \\
\text { tentar } \\
\text { aumentar o } \\
\text { salário, mas } \\
\text { exige ou não } \\
\text { sinaliza a } \\
\text { importância da } \\
\text { elevação da } \\
\text { escolaridade." } \\
\text { "Papel } \\
\text { educativo e } \\
\text { formativo } \\
\text { relevante pra } \\
\text { formar } \\
\text { trabalhadores } \\
\text { na área do } \\
\text { turismo } \\
\text { pensando a } \\
\text { formação da } \\
\end{array}$ & $\begin{array}{l}\text { "necessidade } \\
\text { de qualificação } \\
\text { continuada." } \\
\text { "A gente } \\
\text { começa a } \\
\text { pensar que a } \\
\text { formação da } \\
\text { cidadania é o } \\
\text { tempo todo." } \\
\text { "Assedio deve } \\
\text { ser tema dos } \\
\text { cursos das } \\
\text { áreas, casais } \\
\text { homossexual, } \\
\text { temáticas para } \\
\text { ser } \\
\text { abordadas." }\end{array}$ & $\begin{array}{l}\text { "poucas } \\
\text { horas, } \\
\text { requisito } \\
\text { baixo, } \\
\text { impulsiona a } \\
\text { qualificação } \\
\text { para o } \\
\text { trabalho, não } \\
\text { possibilita a } \\
\text { elevação da } \\
\text { escolaridade. } \\
\text { " } \\
\text { "Algumas } \\
\text { vezes a } \\
\text { gente viu } \\
\text { cursos que } \\
\text { estavam no } \\
\text { catálogo, que } \\
\text { tinham uma } \\
\text { grande } \\
\text { procura, mas } \\
\text { que os } \\
\text { ofertantes } \\
\text { não tinham } \\
\text { condições, } \\
\text { ou porque } \\
\text { eram cursos } \\
\text { caros, } \\
\text { sommelier, } \\
\text { sushiman, } \\
\text { que } \\
\text { demandava } \\
\text { m insumos, } \\
\text { um local }\end{array}$ & $\begin{array}{l}\text { "Poderia ter sido } \\
\text { melhor se tivesse } \\
\text { mais tempo." } \\
\text { "Poderia ter sido } \\
\text { mais produtivo, mais } \\
\text { cooperação do } \\
\text { hotel". } \\
\text { "as aulas } \\
\text { privilegiavam as } \\
\text { questões teóricas, } \\
\text { mas sempre com o } \\
\text { olhar para a prática". } \\
\text { "os participantes } \\
\text { tiveram um } \\
\text { conhecimento } \\
\text { importante e deu a } \\
\text { oportunidade para } \\
\text { essas pessoas } \\
\text { saberem que podem } \\
\text { fazer a diferença." } \\
\text { "aumentar a carga } \\
\text { horaria e ter mais } \\
\text { aulas praticas." } \\
\text { "Universalizar um } \\
\text { padrão, referencia, } \\
\text { trazer cursos de } \\
\text { referência } \\
\text { internacional de } \\
\text { hotelaria." }\end{array}$ & $\begin{array}{l}\text { "Resistência } \\
\text { dos } \\
\text { funcionários, } \\
\text { depois } \\
\text { gostaram, e } \\
\text { queriam fazer } \\
\text { mais } \\
\text { qualificação." } \\
\text { "Seguro } \\
\text { desemprego: } \\
\text { não entendiam } \\
\text { a necessidade } \\
\text { de fazer os } \\
\text { cursos, } \\
\text { trabalho para } \\
\text { manter o } \\
\text { aluno em sala } \\
\text { de aula." } \\
\text { "Começou } \\
\text { com } 20 \text { alunos } \\
\text { e terminou } \\
\text { com } 6 / 8 . "\end{array}$ & $\begin{array}{l}\text { "a participação } \\
\text { nos cursos } \\
\text { ficavam a mercê } \\
\text { da vontade do } \\
\text { patrão." } \\
\text { "Os cursos de } \\
\text { idiomas foram os } \\
\text { mais } \\
\text { procurados." }\end{array}$ & $\begin{array}{l}\text { "as iniciativas } \\
\text { para adequar } \\
\text { os cursos } \\
\text { partiam dos } \\
\text { docentes." } \\
\text { "não participei } \\
\text { de outros } \\
\text { cursos." } \\
\text { "aprendi, e } \\
\text { gostei } \\
\text { bastante, mas } \\
\text { não estou } \\
\text { pronta para } \\
\text { voltar a } \\
\text { estudar o } \\
\text { formal." } \\
\text { "Tenho } \\
\text { vontade de } \\
\text { voltar a } \\
\text { estudar, } \\
\text { realizar uma } \\
\text { graduação na } \\
\text { área." }\end{array}$ & $\begin{array}{l}\text { "A iniciativa } \\
\text { privada } \\
\text { percebeu tarde } \\
\text { os cursos e deu } \\
\text { pouco valor, } \\
\text { diziam que } \\
\text { tinham recurso } \\
\text { para qualificar, } \\
\text { mas não tinham } \\
\text { demanda". } \\
\text { "É necessário } \\
\text { um processo } \\
\text { mais eficiente e } \\
\text { eficaz por parte } \\
\text { do Governo } \\
\text { Federal para o } \\
\text { bom } \\
\text { funcionamento } \\
\text { do programa." }\end{array}$ \\
\hline
\end{tabular}




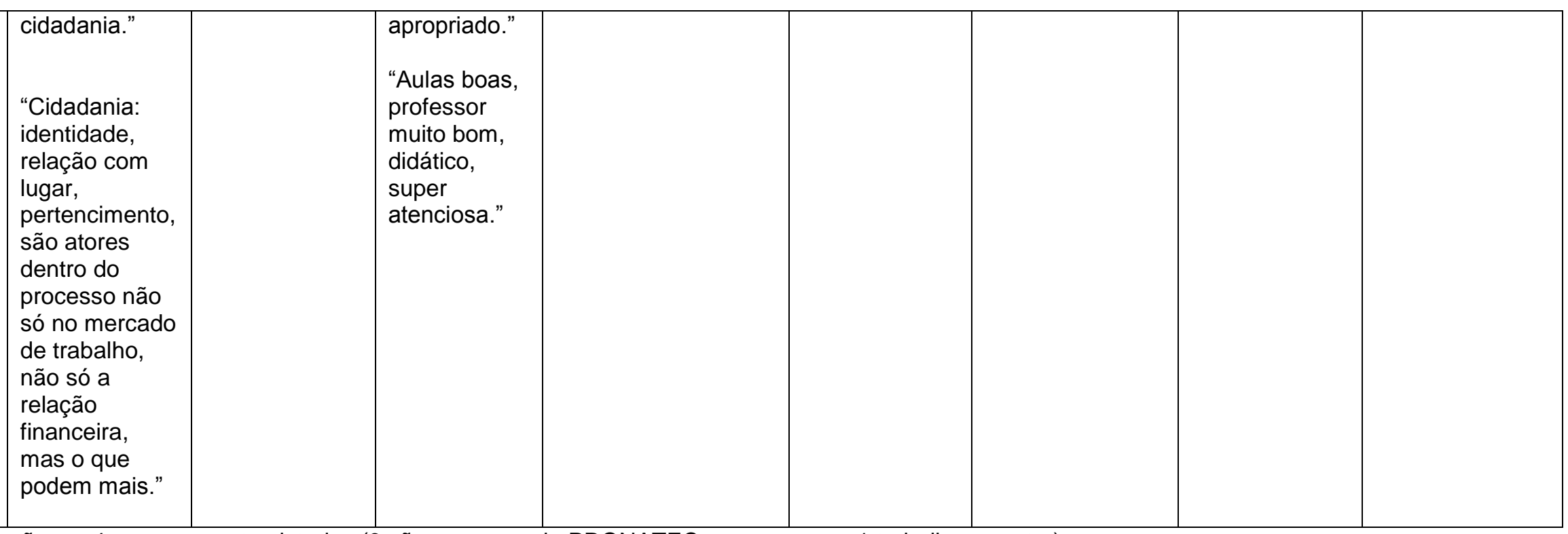

Observação: os 4 egressos entrevistados (3 são egressos do PRONATEC na empresa e 1 trabalha no setor). 
Fortaleza 4 entrevistas (gestores e instrutores do PRONATEC Turismo)

\begin{tabular}{|c|c|c|c|c|c|c|c|c|}
\hline \multicolumn{3}{|c|}{ CATEGORIAS A PRIORI } & \multicolumn{6}{|c|}{ CATEGORIAS MATERIALISMO HISTORICO-DIALETICO } \\
\hline Categorias & Concepções & Avanços & $\begin{array}{l}\text { Teoria } \\
\text { prática }\end{array}$ & $\begin{array}{l}\text { Totalidade } \\
\text { fragmentação }\end{array}$ & $\begin{array}{l}\text { Contradição } \\
\text { mediação }\end{array}$ & $\begin{array}{l}\text { Subjetividade } \\
\text { objetividade }\end{array}$ & $\begin{array}{l}\text { Autonomia } \\
\text { dependência }\end{array}$ & $\begin{array}{l}\text { Criticidade } \\
\text { alienação }\end{array}$ \\
\hline $\begin{array}{l}\text { Inclusão social: } \\
\text { a inclusão dos } \\
\text { sujeitos é } \\
\text { determinante para } \\
\text { uma vida ativa e o } \\
\text { equilíbrio das } \\
\text { oportunidades em } \\
\text { sociedade, } \\
\text { considerando que } \\
\text { essa inclusão } \\
\text { prioritariamente } \\
\text { começa pelo acesso } \\
\text { ao emprego } \\
\text { qualificante, } \\
\text { possibilitador do } \\
\text { crescimento } \\
\text { profissional, espaço } \\
\text { onde o trabalhador } \\
\text { possa criar, } \\
\text { desenvolver-se e ter } \\
\text { suas individualidades } \\
\text { respeitadas. Acesso } \\
\text { aos direitos sociais, } \\
\text { políticos, civis, } \\
\text { econômicos, } \\
\text { culturais e ao lazer. }\end{array}$ & $\begin{array}{l}\text { "A qualificação } \\
\text { tem um papel } \\
\text { de inclusão } \\
\text { social. } \\
\text { Culturalmente } \\
\text { ele vai ser } \\
\text { mais } \\
\text { valorizado, } \\
\text { melhorar a sua } \\
\text { vida." }\end{array}$ & $\begin{array}{l}\text { "deveriam } \\
\text { fazer cursos } \\
\text { mais } \\
\text { direcionados, } \\
\text { analisar a } \\
\text { carga } \\
\text { horária; } \\
\text { aulas } \\
\text { práticas para } \\
\text { motivar o } \\
\text { aluno; } \\
\text { mobilizar os } \\
\text { empresários. } \\
\text { " }\end{array}$ & $\begin{array}{l}\text { "Acompanhament } \\
\text { o não existe, pois } \\
\text { o maior obstáculo } \\
\text { é o capital } \\
\text { humano e } \\
\text { financeiro." } \\
\text { "Com alunos do } \\
\text { PRONATEC, não } \\
\text { sabemos } \\
\text { onde/como } \\
\text { estão." } \\
\text { "Não teve } \\
\text { acompanhamento } \\
\text {, por questão de } \\
\text { tempo e outras } \\
\text { atividades } \\
\text { demandadas." }\end{array}$ & $\begin{array}{l}\text { "Sondagem não } \\
\text { houve." } \\
\text { "o ideal seriam ações } \\
\text { corretivas (terminar } \\
\text { um curso, começar } \\
\text { outro e a inserção no } \\
\text { mercado, apoio } \\
\text { financeiro adequado) } \\
\text { e não preventivas". } \\
\text { "Não conseguiam } \\
\text { montar turmas; } \\
\text { empresários não } \\
\text { liberavam seus } \\
\text { funcionários; maior } \\
\text { gargalo é o } \\
\text { empresário." } \\
\text { "A qualificação na } \\
\text { visão do empresário } \\
\text { era para não querer, } \\
\text { porque o empregado } \\
\text { ia para a } \\
\text { concorrência, cerca } \\
\text { de } 36 \% \text {, e nesse } \\
\text { pensamento quem } \\
\text { perde é o } \\
\text { empresário." }\end{array}$ & & & $\begin{array}{l}\text { "Poucos } \\
\text { egressos } \\
\text { empregados. } \\
\text { O profissional } \\
\text { do Turismo é } \\
\text { mal } \\
\text { remunerado e } \\
\text { isso dificulta } \\
\text { muito." } \\
\text { "Positivo: } \\
\text { crescimento } \\
\text { pessoal, } \\
\text { inserção no } \\
\text { mercado de } \\
\text { trabalho." }\end{array}$ & $\begin{array}{l}\text { "A } \\
\text { preocupação } \\
\text { era somente } \\
\text { com números." } \\
\text { "O que faltou } \\
\text { foi a prática, } \\
\text { aprender } \\
\text { como é que se } \\
\text { vai trabalhar." }\end{array}$ \\
\hline
\end{tabular}




\begin{tabular}{|c|c|c|c|c|c|c|c|c|}
\hline \multicolumn{3}{|c|}{ CATEGORIAS A PRIORI } & \multicolumn{6}{|c|}{ CATEGORIAS MATERIALISMO HISTORICO-DIALETICO } \\
\hline Categorias & Concepções & Avanços & $\begin{array}{l}\text { Teoria } \\
\text { prática }\end{array}$ & $\begin{array}{l}\text { Totalidade } \\
\text { fragmentação }\end{array}$ & $\begin{array}{l}\text { Contradição } \\
\text { mediação }\end{array}$ & $\begin{array}{l}\text { Subjetividade } \\
\text { objetividade }\end{array}$ & $\begin{array}{l}\text { Autonomia } \\
\text { dependência }\end{array}$ & $\begin{array}{l}\text { Criticidade } \\
\text { alienação }\end{array}$ \\
\hline $\begin{array}{l}\text { Desenvolvimento } \\
\text { humano/ } \\
\text { Cidadania } \\
\text { E intrínseco ao } \\
\text { desenvolvimento } \\
\text { humano a cidadania } \\
\text { que pressupõe } \\
\text { equidade de } \\
\text { oportunidades. } \\
\text { Tais como ingresso } \\
\text { ao trabalho digno, } \\
\text { acesso à } \\
\text { aposentadoria, à } \\
\text { segurança, à } \\
\text { habitação, à } \\
\text { educação, ao direito, } \\
\text { à cultura e ao lazer, } \\
\text { fatores essenciais } \\
\text { para a consolidação } \\
\text { da cidadania. E } \\
\text { requisitos para o } \\
\text { desenvolvimento } \\
\text { humano, assim como } \\
\text { a educação integral } \\
\text { dos sujeitos, que } \\
\text { tenha como objetivo } \\
\text { a cidadania, a } \\
\text { liberdade, a } \\
\text { autonomia e a } \\
\text { emancipação. }\end{array}$ & $\begin{array}{l}\text { "Quanto ao } \\
\text { método e a } \\
\text { didática tem } \\
\text { que melhorar } \\
\text { muito." } \\
\text { "A cidadania } \\
\text { era } \\
\text { trabalhada, } \\
\text { mas depende } \\
\text { muito do aluno } \\
\text { se ele quer." }\end{array}$ & & $\begin{array}{l}\text { "Evasão não } \\
\text { tinha muito, } \\
\text { por que os } \\
\text { alunos tinham } \\
\text { interesse pelo } \\
\text { curso e a } \\
\text { ajuda de custo } \\
\text { também era } \\
\text { um } \\
\text { incentivador." } \\
\text { "Vejo que não } \\
\text { contribuiu para } \\
\text { retornar para a } \\
\text { educação } \\
\text { formal, porque } \\
\text { não é o } \\
\text { público alvo da } \\
\text { área e a vida } \\
\text { social deles } \\
\text { não ajuda, } \\
\text { sem muita } \\
\text { perspectiva e } \\
\text { uma estima } \\
\text { baixíssima". }\end{array}$ & $\begin{array}{l}\text { "Conteúdos: veio de } \\
\text { cima para baixo, já } \\
\text { determinado. A } \\
\text { construção da grade } \\
\text { curricular feita pela } \\
\text { coordenação e o } \\
\text { plano de disciplina } \\
\text { pelo professor." } \\
\text { "Professor elaborava } \\
\text { sua própria } \\
\text { apostila/conteúdo." } \\
\text { "Evasão muito } \\
\text { grande, devido a } \\
\text { carga horária } \\
\text { elevada e uma } \\
\text { rotatividade } \\
\text { elevada." }\end{array}$ & $\begin{array}{l}\text { "Permitiram a } \\
\text { transferência } \\
\text { do } \\
\text { conhecimento, } \\
\text { mas com uma } \\
\text { disparidade } \\
\text { entre os } \\
\text { alunos." } \\
\text { "O conteúdo } \\
\text { era adequado, } \\
\text { mas o perfil do } \\
\text { aluno não." }\end{array}$ & & & $\begin{array}{l}\text { "O curso } \\
\text { PRONATEC é } \\
\text { muito } \\
\text { equivocado para } \\
\text { o perfil do aluno, } \\
\text { não existe um } \\
\text { encaminhament } \\
\text { o e sem muito } \\
\text { objetivo é } \\
\text { somente } \\
\text { números para o } \\
\text { governo". } \\
\text { "Poder público: } \\
\text { muito } \\
\text { assistencialista } \\
\text { e sem resultado } \\
\text { algum. O papel } \\
\text { do poder público } \\
\text { não é preventivo } \\
\text { e tenta ser } \\
\text { corretivo." }\end{array}$ \\
\hline
\end{tabular}


Rio de Janeiro entrevistas 10 (egressos, gestores e instrutores do PRONATEC Turismo)

\begin{tabular}{|c|c|c|c|c|c|c|c|c|}
\hline \multicolumn{3}{|c|}{ CATEGORIAS A PRIORI } & \multicolumn{6}{|c|}{ CATEGORIAS MATERIALISMO HISTORICO-DIALETICO } \\
\hline Categorias & Concepções & Avanços & $\begin{array}{l}\text { Teoria } \\
\text { Prática }\end{array}$ & $\begin{array}{l}\text { Totalidade } \\
\text { fragmentação }\end{array}$ & $\begin{array}{l}\text { Contradição } \\
\text { mediação }\end{array}$ & $\begin{array}{l}\text { Subjetividade } \\
\text { objetividade }\end{array}$ & $\begin{array}{l}\text { Autonomia } \\
\text { dependência }\end{array}$ & $\begin{array}{l}\text { Criticidade } \\
\text { alienação }\end{array}$ \\
\hline $\begin{array}{l}\text { Inclusão social: } \\
\text { a inclusão dos } \\
\text { sujeitos é } \\
\text { determinante para } \\
\text { uma vida ativa e o } \\
\text { equilíbrio das } \\
\text { oportunidades em } \\
\text { sociedade, } \\
\text { considerando que } \\
\text { essa inclusão } \\
\text { prioritariamente } \\
\text { começa pelo acesso } \\
\text { ao emprego } \\
\text { qualificante, } \\
\text { possibilitador do } \\
\text { crescimento } \\
\text { profissional, espaço } \\
\text { onde o trabalhador } \\
\text { possa criar, } \\
\text { desenvolver-se e ter } \\
\text { suas } \\
\text { individualidades } \\
\text { respeitadas. Acesso } \\
\text { aos direitos sociais, } \\
\text { políticos, civis, } \\
\text { econômicos, } \\
\text { culturais e ao lazer. }\end{array}$ & $\begin{array}{l}\text { "A formação e } \\
\text { muito } \\
\text { importante } \\
\text { para a } \\
\text { inclusão } \\
\text { social." } \\
\text { "falta muita } \\
\text { qualificação } \\
\text { aos } \\
\text { profissionais } \\
\text { do setor." }\end{array}$ & $\begin{array}{l}\text { "Deveria ter } \\
\text { indicação } \\
\text { sobre o } \\
\text { mercado e } \\
\text { postos de } \\
\text { trabalho para } \\
\text { a inserção } \\
\text { dos alunos." } \\
\text { "ter parcerias } \\
\text { para } \\
\text { intermediaçã } \\
\text { o ao } \\
\text { mercado de } \\
\text { trabalho." } \\
\text { "Precisa } \\
\text { avançar no } \\
\text { ensino } \\
\text { profissional, } \\
\text { focar apenas } \\
\text { em } \\
\text { competência } \\
\text { s não basta." }\end{array}$ & $\begin{array}{l}\text { "se trabalha muito, a } \\
\text { remuneração e baixa, os } \\
\text { profissionais não são } \\
\text { reconhecidos e muitas } \\
\text { vezes mal tratados." } \\
\text { "O curso contribuiu, o } \\
\text { diploma acrescenta ao } \\
\text { currículo." } \\
\text { (desempregada) } \\
\text { "o curso foi importante } \\
\text { para despertar o } \\
\text { interesse pela área." } \\
\text { "a parte técnica precisa } \\
\text { ser bem apurada, porque } \\
\text { visa atender o mercado." } \\
\text { "os cursos estão focados } \\
\text { em teoria, falta pratica" }\end{array}$ & $\begin{array}{l}\text { "A ampliação } \\
\text { do } \\
\text { conhecimento e } \\
\text { importante para } \\
\text { ampliar o } \\
\text { horizonte e abrir } \\
\text { portas". } \\
\text { (desempregada) } \\
\text { "O aluno quer } \\
\text { fazer o curso } \\
\text { para se } \\
\text { empregar." }\end{array}$ & $\begin{array}{l}\text { "existe } \\
\text { possibilidade } \\
\text { de } \\
\text { crescimento } \\
\text { profissional, } \\
\text { mas a } \\
\text { remuneração } \\
\text { não e } \\
\text { vantajosa." } \\
\text { "o programa } \\
\text { já e } \\
\text { inclusivo, } \\
\text { mas não sei } \\
\text { ate que } \\
\text { ponto isso } \\
\text { ocorre." } \\
\text { "muitos } \\
\text { alunos saem } \\
\text { porque } \\
\text { arrumam um } \\
\text { emprego e } \\
\text { precisam } \\
\text { sobreviver." }\end{array}$ & $\begin{array}{l}\text { "não fiz outros } \\
\text { cursos." } \\
\text { "não estou } \\
\text { conseguindo } \\
\text { trabalho para } \\
\text { poder dar } \\
\text { continuidade } \\
\text { aos meus } \\
\text { planos } \\
\text { profissionais." }\end{array}$ & $\begin{array}{l}\text { "o setor e } \\
\text { dinâmico e } \\
\text { motivante." } \\
\text { "o curso foi } \\
\text { excelente, } \\
\text { muito } \\
\text { importante } \\
\text { para minha } \\
\text { atuação." } \\
\text { (empresário) } \\
\text { "ajudei umas } \\
5 \text { pessoas a } \\
\text { ingressarem } \\
\text { no mercado } \\
\text { de trabalho } \\
\text { do setor." } \\
\text { "necessidad } \\
\text { e de outro } \\
\text { idioma para } \\
\text { a inserção } \\
\text { no mercado } \\
\text { de trabalho." } \\
\text { "trabalho } \\
\text { como } \\
\text { garçonete." }\end{array}$ & $\begin{array}{l}\text { "a } \\
\text { remuneração } \\
\text { do setor e } \\
\text { desfavorável." } \\
\text { "qualificar só } \\
\text { por qualificar } \\
\text { sem um } \\
\text { encaminhame } \\
\text { nto não } \\
\text { resolve." }\end{array}$ \\
\hline
\end{tabular}




\begin{tabular}{|c|c|c|c|c|c|c|c|c|}
\hline \multicolumn{3}{|c|}{ CATEGORIAS A PRIORI } & \multicolumn{6}{|c|}{ CATEGORIAS MATERIALISMO HISTORICO-DIALETICO } \\
\hline Categorias & Concepções & Avanços & $\begin{array}{l}\text { Teoria } \\
\text { Prática }\end{array}$ & $\begin{array}{l}\text { Totalidade } \\
\text { fragmentação }\end{array}$ & $\begin{array}{l}\text { Contradição } \\
\text { mediação }\end{array}$ & $\begin{array}{l}\text { Subjetividade } \\
\text { objetividade }\end{array}$ & $\begin{array}{l}\text { Autonomia } \\
\text { dependência }\end{array}$ & $\begin{array}{l}\text { Criticidade } \\
\text { alienação }\end{array}$ \\
\hline $\begin{array}{l}\text { Desenvolvimento } \\
\text { humano/ } \\
\text { Cidadania } \\
\text { E intrínseco ao } \\
\text { desenvolvimento } \\
\text { humano a cidadania } \\
\text { que pressupõe } \\
\text { equidade de } \\
\text { oportunidades. } \\
\text { Tais como ingresso } \\
\text { ao trabalho digno, } \\
\text { acesso à } \\
\text { aposentadoria, à } \\
\text { segurança, à } \\
\text { habitação, à } \\
\text { educação, ao direito, } \\
\text { à cultura e ao lazer, } \\
\text { fatores essenciais } \\
\text { para a consolidação } \\
\text { da cidadania. E } \\
\text { requisitos para o } \\
\text { desenvolvimento } \\
\text { humano, assim } \\
\text { como a educação } \\
\text { integral dos sujeitos, } \\
\text { que tenha como } \\
\text { objetivo a cidadania, } \\
\text { a liberdade, a } \\
\text { autonomia e a } \\
\text { emancipação. }\end{array}$ & $\begin{array}{l}\text { "O programa } \\
\text { por si só já } \\
\text { induz a } \\
\text { cidadania." } \\
\text { "o curso } \\
\text { proporcionou } \\
\text { entender as } \\
\text { diversidades } \\
\text { culturais, e } \\
\text { diminuir os } \\
\text { preconceitos. } \\
\text { " } \\
\text { "foram } \\
\text { trabalhados } \\
\text { conteúdos de } \\
\text { ética, } \\
\text { empreended } \\
\text { orismo." } \\
\text { "Deve incluir } \\
\text { outras } \\
\text { formações, } \\
\text { não só a } \\
\text { formação } \\
\text { técnica." }\end{array}$ & $\begin{array}{l}\text { "os cursos } \\
\text { precisam ser } \\
\text { reestruturados } \\
\text { "e necessário } \\
\text { utilizar } \\
\text { metodologias } \\
\text { e dinâmicas } \\
\text { que consigam } \\
\text { trazer o aluno } \\
\text { para esse } \\
\text { novo mundo." } \\
\text { "trabalha-se o } \\
\text { conteúdo ser } \\
\text { cidadão (a } \\
\text { partir de } \\
\text { 2015)". }\end{array}$ & $\begin{array}{l}\text { Abordagem indireta } \\
\text { da cidadania. } \\
\text { "O curso não } \\
\text { acrescentou em } \\
\text { relação à } \\
\text { cidadania." } \\
\text { "conteúdos muito } \\
\text { bons e excelentes } \\
\text { professores." } \\
\text { "faltou qualidade no } \\
\text { material didático." } \\
\text { "necessidade de } \\
\text { maior carga horaria } \\
\text { e de mais } \\
\text { atividades } \\
\text { praticas." } \\
\text { "ter mais visitas } \\
\text { ténicas." } \\
\text { "Muito alunos } \\
\text { estavam ali por } \\
\text { obrigação, apenas } \\
\text { para receber o } \\
\text { seguro } \\
\text { desemprego." }\end{array}$ & $\begin{array}{l}\text { "A ação e boa, } \\
\text { mas precisa ter } \\
\text { ajustes." } \\
\text { "houve muita } \\
\text { evasão." } \\
\text { "todos querem } \\
\text { entrar nos cursos, } \\
\text { mas manter-se } \\
\text { para alguns e um } \\
\text { problema." } \\
\text { "o cursos começou } \\
\text { com uns 30, mas } \\
\text { acabou com 10/12 } \\
\text { alunos." } \\
\text { "nível baixo de } \\
\text { escolaridade dos } \\
\text { alunos." } \\
\text { "atraso no repasse } \\
\text { das bolsas } \\
\text { ocasionaram } \\
\text { evasões." } \\
\text { "Distância, } \\
\text { dificuldades para } \\
\text { chegar." }\end{array}$ & $\begin{array}{l}\text { "muita gente } \\
\text { se inscreve e } \\
\text { não aparece." } \\
\text { "o material } \\
\text { didático foi } \\
\text { focado na } \\
\text { parte técnica." } \\
\text { "e difícil incutir } \\
\text { na cabeça das } \\
\text { pessoas que } \\
\text { precisam se } \\
\text { esforçar para } \\
\text { atingir seus } \\
\text { objetivos." } \\
\text { "existem } \\
\text { vivências } \\
\text { praticas, mas } \\
\text { não são } \\
\text { especificas ao } \\
\text { Programa." }\end{array}$ & $\begin{array}{l}\text { "dificuldade } \\
\text { para lidar com } \\
\text { o turista } \\
\text { estrangeiro por } \\
\text { falta do } \\
\text { idioma." } \\
\text { "os } \\
\text { professores } \\
\text { fizeram os } \\
\text { conteúdos." } \\
\text { "o professor } \\
\text { que decide se } \\
\text { vai dar } \\
\text { atividades } \\
\text { praticas." }\end{array}$ & $\begin{array}{l}\text { "fiz outros } \\
\text { cursos na } \\
\text { área." } \\
\text { "pensei em } \\
\text { fazer } \\
\text { graduação em } \\
\text { turismo, mas } \\
\text { não posso } \\
\text { financeiramente } \\
. " \\
\text { "interesse em } \\
\text { fazer outros } \\
\text { cursos gratuitos } \\
\text { na área." } \\
\text { "fiz um curso de } \\
\text { somemellier após } \\
\text { o de bartender." } \\
\text { "estava } \\
\text { cursando } \\
\text { gastronomia e } \\
\text { me formei." } \\
\text { "fiz um segundo } \\
\text { curso no setor." }\end{array}$ & $\begin{array}{l}\text { "Carga } \\
\text { horaria } \\
\text { reduzida } \\
\text { para o } \\
\text { aprendizado } \\
\text { de um } \\
\text { idioma." } \\
\text { "carga } \\
\text { horaria maior } \\
\text { para } \\
\text { conversação. } \\
\text { " } \\
\text { "maior } \\
\text { divulgação } \\
\text { dos cursos } \\
\text { para } \\
\text { proporcionar } \\
\text { maior } \\
\text { acesso." } \\
\text { "falta } \\
\text { nivelamento } \\
\text { da } \\
\text { escolaridade } \\
\text { dos alunos." } \\
\text { "faltou } \\
\text { divulgação } \\
\text { dos cursos } \\
\text { do } \\
\text { programa." }\end{array}$ \\
\hline
\end{tabular}

Observação: 7 egressos (4 trabalham na área, desses 1 como freelance e 1 já era dono de buffet) 
Natal - 12 entrevistas (egressos, gestores e instrutores do PRONATEC Turismo)

\begin{tabular}{|c|c|c|c|c|c|c|c|c|}
\hline \multicolumn{3}{|c|}{ CATEGORIAS A PRIORI } & \multicolumn{6}{|c|}{ CATEGORIAS MATERIALISMO HISTORICO-DIALETICO } \\
\hline Categorias & Concepções & Avanços & $\begin{array}{l}\text { Teoria/prátic } \\
\text { a }\end{array}$ & $\begin{array}{l}\text { Totalidade } \\
\text { fragmentação }\end{array}$ & $\begin{array}{l}\text { Contradição } \\
\text { mediação }\end{array}$ & $\begin{array}{l}\text { Subjetividad } \\
\text { e } \\
\text { objetividade }\end{array}$ & $\begin{array}{l}\text { Autonomia } \\
\text { dependência }\end{array}$ & $\begin{array}{l}\text { Criticidade } \\
\text { alienação }\end{array}$ \\
\hline $\begin{array}{l}\text { Inclusão social: } \\
\text { a inclusão dos } \\
\text { sujeitos é } \\
\text { determinante para } \\
\text { uma vida ativa e o } \\
\text { equilíbrio das } \\
\text { oportunidades em } \\
\text { sociedade, } \\
\text { considerando que } \\
\text { essa inclusão } \\
\text { prioritariamente } \\
\text { começa pelo acesso } \\
\text { ao emprego } \\
\text { qualificante, } \\
\text { possibilitador do } \\
\text { crescimento } \\
\text { profissional, espaço } \\
\text { onde o trabalhador } \\
\text { possa criar, } \\
\text { desenvolver-se e ter } \\
\text { suas individualidades } \\
\text { respeitadas. Acesso } \\
\text { aos direitos sociais, } \\
\text { políticos, civis, } \\
\text { econômicos, } \\
\text { culturais e ao lazer. }\end{array}$ & $\begin{array}{l}\text { “é de grande } \\
\text { valia os } \\
\text { ensinamento } \\
\text { s repassados } \\
\text { na ocasião } \\
\text { dos cursos } \\
\text { de } \\
\text { qualificação } \\
\text { e isso } \\
\text { possibilita } \\
\text { uma } \\
\text { oportunidade } \\
\text { de } \\
\text { capacitação } \\
\text { e } \\
\text { profissionaliz } \\
\text { ação dos } \\
\text { indivíduos. } \\
\text { Com isso, é } \\
\text { possível } \\
\text { galgar a } \\
\text { inserção } \\
\text { dessas } \\
\text { pessoas no } \\
\text { mercado de } \\
\text { trabalho, } \\
\text { contribuindo } \\
\text { assim para a } \\
\text { sua } \\
\text { ascensão } \\
\text { social”. }\end{array}$ & $\begin{array}{l}\text { "Foi percebida a } \\
\text { necessidade de } \\
\text { uma maior } \\
\text { aproximação com } \\
\text { a iniciativa } \\
\text { privada, no intuito } \\
\text { de elaborar } \\
\text { estratégias para } \\
\text { inserir esses } \\
\text { colaboradores em } \\
\text { cursos de } \\
\text { qualificação". } \\
\text { "Os programas } \\
\text { carecem de uma } \\
\text { sintonia fina entre } \\
\text { o que é ofertado } \\
\text { em termos de } \\
\text { cursos de } \\
\text { qualificação } \\
\text { profissional e os } \\
\text { interesses da } \\
\text { comunidade; } \\
\text { entre o perfil } \\
\text { profissional do } \\
\text { aluno egresso e } \\
\text { as necessidades } \\
\text { do arranjo } \\
\text { produtivo local". }\end{array}$ & $\begin{array}{l}\text { "É preciso } \\
\text { que haja uma } \\
\text { formatação } \\
\text { mais } \\
\text { adequada } \\
\text { em relação } \\
\text { aos cursos. } \\
\text { O alto índice } \\
\text { de evasão, o } \\
\text { baixo } \\
\text { aproveitamen } \\
\text { to pelo } \\
\text { mercado e o } \\
\text { desinteresse } \\
\text { dos alunos } \\
\text { na obtenção } \\
\text { do } \\
\text { conheciment } \\
\text { o, são pontos } \\
\text { que reforçam } \\
\text { a } \\
\text { necessidade } \\
\text { de } \\
\text { readequação } \\
\text { " }\end{array}$ & $\begin{array}{l}\text { Em relação à } \\
\text { inserção dos } \\
\text { egressos no } \\
\text { mercado de trabalho: } \\
\text { "não tenho essa } \\
\text { informação". } \\
\text { "Oficialmente não } \\
\text { temos os dados, } \\
\text { porém, em contatos } \\
\text { informais, há uma } \\
\text { absorção por parte } \\
\text { do mercado de } \\
\text { trabalho". } \\
\text { "Os programas } \\
\text { carecem de uma } \\
\text { sintonia fina entre o } \\
\text { que é ofertado em } \\
\text { termos de cursos de } \\
\text { qualificação } \\
\text { profissional e as } \\
\text { demandas de } \\
\text { mercado". }\end{array}$ & $\begin{array}{l}\text { "Resistência } \\
\text { dos } \\
\text { empresários } \\
\text { em liberar os } \\
\text { seus } \\
\text { funcionários } \\
\text { para os } \\
\text { cursos". }\end{array}$ & $\begin{array}{l}\text { "Ele } \\
\text { menciona } \\
\text { que não esta } \\
\text { trabalhando } \\
\text { no momento, } \\
\text { mas sente } \\
\text { que possui } \\
\text { boa base } \\
\text { para poder } \\
\text { atuar na } \\
\text { área." }\end{array}$ & $\begin{array}{l}\text { "Foi verificado } \\
\text { que as } \\
\text { secretarias } \\
\text { locais já } \\
\text { tentaram realizar } \\
\text { algumas } \\
\text { sensibilizações } \\
\text { e inclusive } \\
\text { tentativas de } \\
\text { realizar alguns } \\
\text { cursos no } \\
\text { próprio espaço } \\
\text { de trabalho dos } \\
\text { colaboradores, } \\
\text { entretanto, sem } \\
\text { sucesso." } \\
\text { "O egresso } \\
\text { informa que o } \\
\text { curso ofertado } \\
\text { pela UnP } \\
\text { possibilitou o } \\
\text { seu } \\
\text { conhecimentos } \\
\text { da área do } \\
\text { Turismo e foi o } \\
\text { motivo que o } \\
\text { incentivou a } \\
\text { cursar a } \\
\text { graduação em } \\
\text { Turismo. }\end{array}$ & $\begin{array}{l}\text { "Percebeu-se } \\
\text { a falta de uma } \\
\text { orientação } \\
\text { profissional e } \\
\text { pessoal para a } \\
\text { continuidade } \\
\text { da formação, } \\
\text { apesar de } \\
\text { muitos relatos } \\
\text { apontarem } \\
\text { que a } \\
\text { participação } \\
\text { no curso foi } \\
\text { estimuladora } \\
\text { para a } \\
\text { continuidade } \\
\text { dos estudos". }\end{array}$ \\
\hline
\end{tabular}




\begin{tabular}{|c|c|c|c|c|c|c|c|c|}
\hline \multicolumn{3}{|c|}{ CATEGORIAS A PRIORI } & \multicolumn{6}{|c|}{ CATEGORIAS MATERIALISMO HISTORICO-DIALETICO } \\
\hline Categorias & Concepções & Avanços & $\begin{array}{l}\text { Teoria } \\
\text { Prática }\end{array}$ & $\begin{array}{l}\text { Totalidade } \\
\text { fragmentação }\end{array}$ & $\begin{array}{l}\text { Contradição } \\
\text { mediação }\end{array}$ & $\begin{array}{l}\text { Subjetividade } \\
\text { objetividade }\end{array}$ & $\begin{array}{l}\text { Autonomia } \\
\text { dependência }\end{array}$ & $\begin{array}{l}\text { Criticidade } \\
\text { alienação }\end{array}$ \\
\hline $\begin{array}{l}\text { Desenvolvimento } \\
\text { humano/ } \\
\text { Cidadania } \\
\text { E intrínseco ao } \\
\text { desenvolvimento } \\
\text { humano a cidadania } \\
\text { que pressupõe } \\
\text { equidade de } \\
\text { oportunidades. } \\
\text { Tais como ingresso } \\
\text { ao trabalho digno, } \\
\text { acesso à } \\
\text { aposentadoria, à } \\
\text { segurança, à } \\
\text { habitação, à } \\
\text { educação, ao direito, } \\
\text { à cultura e ao lazer, } \\
\text { fatores essenciais } \\
\text { para a consolidação } \\
\text { da cidadania. E } \\
\text { requisitos para o } \\
\text { desenvolvimento } \\
\text { humano, assim como } \\
\text { a educação integral } \\
\text { dos sujeitos, que } \\
\text { tenha como objetivo } \\
\text { a cidadania, a } \\
\text { liberdade, a } \\
\text { autonomia e a } \\
\text { emancipação. }\end{array}$ & $\begin{array}{l}\text { "com o } \\
\text { aprofundamento } \\
\text { e ampliação do } \\
\text { conhecimento a } \\
\text { partir da } \\
\text { participação nos } \\
\text { cursos de } \\
\text { qualificação, os } \\
\text { alunos passam } \\
\text { a ter um } \\
\text { interesse em se } \\
\text { envolver e } \\
\text { participar das } \\
\text { questões } \\
\text { referentes à } \\
\text { área do turismo, } \\
\text { de modo a } \\
\text { debater sobre } \\
\text { esses assuntos } \\
\text { e serem mais } \\
\text { críticos". } \\
\text { O educando } \\
\text { deve aprender a } \\
\text { reconhecer e } \\
\text { praticar a } \\
\text { essência do ser } \\
\text { cidadão, a } \\
\text { saber: pensar e } \\
\text { agir na vida } \\
\text { pública tendo } \\
\text { como princípio } \\
\text { fundamental o } \\
\text { "cuidado com o } \\
\text { interesse }\end{array}$ & $\begin{array}{l}\text { "Em relação à } \\
\text { cidadania, } \\
\text { ainda há muito } \\
\text { a ser efetivado } \\
\text { para mudar a } \\
\text { percepção dos } \\
\text { alunos em } \\
\text { relação ao } \\
\text { PRONATEC } \\
\text { sobre o seu } \\
\text { papel cidadão, } \\
\text { o papel dos } \\
\text { seus atos para } \\
\text { o } \\
\text { desenvolvime } \\
\text { nto do país e } \\
\text { a necessidade } \\
\text { de inserção } \\
\text { deles nesses } \\
\text { debates." } \\
\text { "A professora } \\
\text { acredita que } \\
\text { esses cursos } \\
\text { tem antes de } \\
\text { tudo o papel } \\
\text { de formar } \\
\text { cidadãos } \\
\text { trabalhadores, } \\
\text { que } \\
\text { contribuam } \\
\text { com a sua } \\
\text { localidade. } \\
\text { Que sejam } \\
\text { estimulados a }\end{array}$ & $\begin{array}{l}\text { "Infelizmente a } \\
\text { maioria dos } \\
\text { alunos afirma } \\
\text { abertamente que } \\
\text { só está } \\
\text { participando dos } \\
\text { cursos para } \\
\text { receber a bolsa, } \\
\text { buscando cursos } \\
\text { com maior carga } \\
\text { horária para } \\
\text { ganhar mais." } \\
\text { "A maioria dos } \\
\text { discentes } \\
\text { estavam } \\
\text { interessados mais } \\
\text { na bolsa ofertada } \\
\text { do que na } \\
\text { capacitação". } \\
\text { "A maior questão } \\
\text { dos cursos do } \\
\text { PRONATEC é } \\
\text { que os alunos } \\
\text { frequentam as } \\
\text { aulas devido à } \\
\text { bolsa auxílio que } \\
\text { recebem, quando } \\
\text { a mesma começa } \\
\text { a atrasar os } \\
\text { alunos se } \\
\text { desinteressam e } \\
\text { abandonam o } \\
\text { curso". }\end{array}$ & $\begin{array}{l}\text { "muitas pessoas } \\
\text { se inscrevem } \\
\text { nos cursos sem } \\
\text { entender bem a } \\
\text { formação } \\
\text { escolhida, } \\
\text { possuem outras } \\
\text { prioridades e } \\
\text { como é gratuito } \\
\text { não se } \\
\text { importam de } \\
\text { abandonar a } \\
\text { formação." } \\
\text { "Percorreram } \\
\text { parcialmente, } \\
\text { em decorrência } \\
\text { da reduzida } \\
\text { carga horária e } \\
\text { da escassez de } \\
\text { materiais } \\
\text { didáticos". } \\
\text { "o PRONATEC } \\
\text { era como querer } \\
\text { "tapar o sol com } \\
\text { a peneira" } \\
\text { porque não e } \\
\text { possível realizar } \\
\text { uma } \\
\text { capacitação } \\
\text { continuada com } \\
\text { cursos de curta } \\
\text { duração." }\end{array}$ & $\begin{array}{l}\text { "PRONATEC } \\
\text { muito mais } \\
\text { como uma } \\
\text { política de } \\
\text { distribuição de } \\
\text { renda do que } \\
\text { de } \\
\text { capacitação". } \\
\text { "Apesar dos } \\
\text { cursos } \\
\text { estarem } \\
\text { cumprindo o } \\
\text { seu papel } \\
\text { social e } \\
\text { educativo, a } \\
\text { sociedade não } \\
\text { tem } \\
\text { conseguido } \\
\text { absorver esta } \\
\text { realidade e } \\
\text { continua } \\
\text { agindo como } \\
\text { se não fosse } \\
\text { responsável } \\
\text { por mudar as } \\
\text { situações a } \\
\text { que são } \\
\text { acometidas". }\end{array}$ & $\begin{array}{l}\text { "Não participo e } \\
\text { os cursos não } \\
\text { influenciaram a } \\
\text { participar". } \\
\text { "O país está } \\
\text { passando por } \\
\text { uma crise } \\
\text { financeira, por } \\
\text { isso é muito } \\
\text { difícil } \\
\text { questionar". }\end{array}$ & $\begin{array}{l}\text { "Quando } \\
\text { questionados } \\
\text { sobre a sua } \\
\text { formação } \\
\text { cidadã, a } \\
\text { maioria dos } \\
\text { egressos } \\
\text { afirmou que } \\
\text { em nada } \\
\text { mudou } \\
\text { depois do } \\
\text { cumprimento } \\
\text { dos cursos } \\
\text { ofertados". }\end{array}$ & $\begin{array}{l}\text { "Percebe-se } \\
\text { cada vez mais } \\
\text { a apatia dos } \\
\text { jovens que } \\
\text { mesmo } \\
\text { estando num } \\
\text { espaço de } \\
\text { diálogo e } \\
\text { reflexão, de } \\
\text { colocar em } \\
\text { prática as } \\
\text { vivências } \\
\text { adquiridas } \\
\text { com os } \\
\text { cursos, os } \\
\text { mesmos } \\
\text { permanecem } \\
\text { inertes as } \\
\text { situações que } \\
\text { envolvem o } \\
\text { ambiente } \\
\text { externo." }\end{array}$ \\
\hline
\end{tabular}




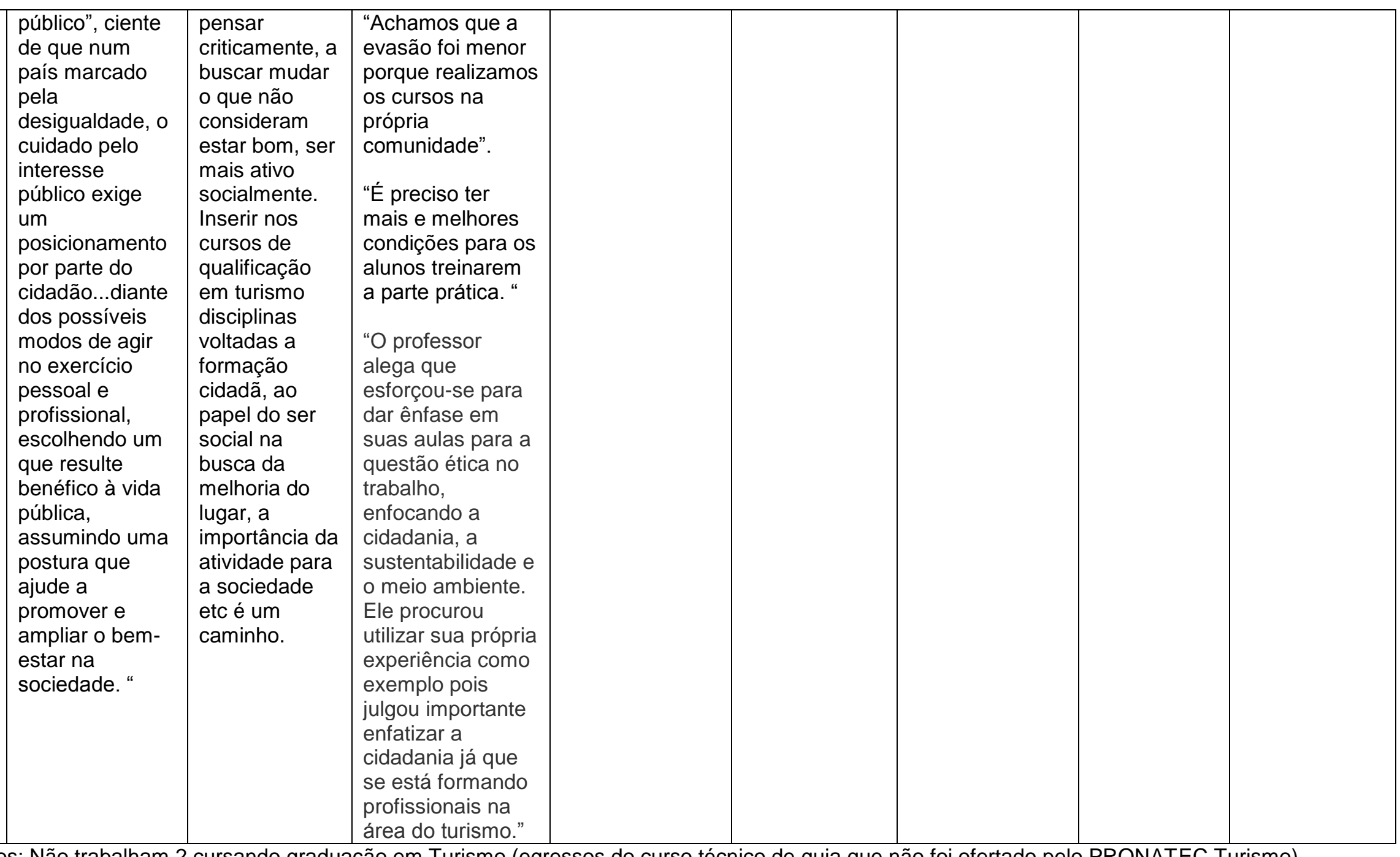

3 egressos: Não trabalham 2 cursando graduação em Turismo (egressos do curso técnico de guia que não foi ofertado pelo PRONATEC Turismo) 
Recife 3 entrevistas (gestores e instrutores do PRONATEC Turismo)

\begin{tabular}{|c|c|c|c|c|c|c|c|c|}
\hline \multicolumn{3}{|c|}{ CATEGORIAS A PRIORI } & \multicolumn{6}{|c|}{ CATEGORIAS MATERIALISMO HISTORICO-DIALETICO } \\
\hline Categorias & Concepções & Avanços & $\begin{array}{l}\text { Teoria } \\
\text { Prática }\end{array}$ & $\begin{array}{l}\text { Totalidade } \\
\text { fragmentação }\end{array}$ & $\begin{array}{l}\text { Contradição } \\
\text { mediação }\end{array}$ & $\begin{array}{l}\text { Subjetividade } \\
\text { objetividade }\end{array}$ & $\begin{array}{l}\text { Autonomia } \\
\text { dependência }\end{array}$ & $\begin{array}{l}\text { Criticidade } \\
\text { alienação }\end{array}$ \\
\hline $\begin{array}{l}\text { Inclusão social: } \\
\text { a inclusão dos } \\
\text { sujeitos é } \\
\text { determinante para } \\
\text { uma vida ativa e o } \\
\text { equilíbrio das } \\
\text { oportunidades em } \\
\text { sociedade, } \\
\text { considerando que } \\
\text { essa inclusão } \\
\text { prioritariamente } \\
\text { começa pelo acesso } \\
\text { ao emprego } \\
\text { qualificante, } \\
\text { possibilitador do } \\
\text { crescimento } \\
\text { profissional, espaço } \\
\text { onde o trabalhador } \\
\text { possa criar, } \\
\text { desenvolver-se e ter } \\
\text { suas individualidades } \\
\text { respeitadas. Acesso } \\
\text { aos direitos sociais, } \\
\text { políticos, civis, } \\
\text { econômicos, } \\
\text { culturais e ao lazer. }\end{array}$ & $\begin{array}{l}\text { "a qualificação } \\
\text { ajuda o } \\
\text { destino, } \\
\text { preparando } \\
\text { melhor a mão } \\
\text { de obra a } \\
\text { trabalhar na } \\
\text { área e para } \\
\text { estar atento } \\
\text { às } \\
\text { necessidades } \\
\text { dos turistas. } \\
\text { No caso da } \\
\text { modalidade } \\
\text { Pronatec } \\
\text { Turismo... o } \\
\text { foco foi nas } \\
\text { pessoas que } \\
\text { tinham } \\
\text { interesse em } \\
\text { se preparar } \\
\text { para ingressar } \\
\text { nesse } \\
\text { mercado, } \\
\text { oportunizando } \\
\text { a } \\
\text { profissionaliza } \\
\text { ção }\end{array}$ & $\begin{array}{l}\text { "Os cursos, } \\
\text { dessa vez, } \\
\text { foram } \\
\text { realizados nas } \\
\text { comunidades, } \\
\text { dentro das } \\
\text { próprias } \\
\text { instituições } \\
\text { para que } \\
\text { diminuíssem a } \\
\text { evasão e se } \\
\text { incentivasse a } \\
\text { comunidade a } \\
\text { se qualificar } \\
\text { para atuar no } \\
\text { mercado } \\
\text { turístico". } \\
\text { "foi feita uma } \\
\text { ação de } \\
\text { aproximação } \\
\text { com o } \\
\text { mercado por } \\
\text { meio do envio } \\
\text { dos currículos } \\
\text { dos alunos que } \\
\text { finalizaram os } \\
\text { cursos". }\end{array}$ & $\begin{array}{l}\text { "a professora } \\
\text { relata que, } \\
\text { infelizmente, a } \\
\text { maioria dos } \\
\text { alunos afirmava } \\
\text { que só estava } \\
\text { participando dos } \\
\text { cursos para } \\
\text { receber a bolsa... } \\
\text {...a escolha do } \\
\text { curso era pautada } \\
\text { na maior carga } \\
\text { horária visando } \\
\text { ganhar mais } \\
\text { tempo de bolsa." } \\
\text { "monitoramento } \\
\text { dos egressos não } \\
\text { é realizado". } \\
\text { "o empresário não } \\
\text { apoia as } \\
\text { iniciativas e } \\
\text { também não } \\
\text { valoriza e nem } \\
\text { prioriza a } \\
\text { contratação do } \\
\text { indivíduo que } \\
\text { concluiu os } \\
\text { cursos } \\
\text { formativos". }\end{array}$ & $\begin{array}{l}\text { "Poucos foram os } \\
\text { alunos que } \\
\text { afirmaram fazer o } \\
\text { curso porque } \\
\text { realmente se } \\
\text { interessavam pela } \\
\text { área." } \\
\text { "as didáticas } \\
\text { promoveram a } \\
\text { melhoria das } \\
\text { competências, } \\
\text { porque nota-se } \\
\text { uma melhoria na } \\
\text { postura de alguns } \\
\text { alunos durante o } \\
\text { curso. Ela } \\
\text { acredita que o } \\
\text { resultado poderia } \\
\text { ser melhor se } \\
\text { houvesse uma } \\
\text { estrutura que } \\
\text { permitisse mais } \\
\text { treino prático, a } \\
\text { exemplo de } \\
\text { laboratórios e } \\
\text { hotel escola." } \\
\text { "trabalhamos em } \\
\text { conjunto com as } \\
\text { entidades do } \\
\text { CNT/PE". }\end{array}$ & $\begin{array}{l}\text { "A professora } \\
\text { compreende } \\
\text { que o } \\
\text { PRONATEC é } \\
\text { muito mais } \\
\text { uma política } \\
\text { de distribuição } \\
\text { de renda do } \\
\text { que de } \\
\text { capacitação". } \\
\text { "Quando } \\
\text { foram } \\
\text { propostas as } \\
\text { ações de } \\
\text { qualificação a } \\
\text { professora } \\
\text { informa que } \\
\text { existiu um } \\
\text { grande } \\
\text { interesse do } \\
\text { trade } \\
\text { envolvido, } \\
\text { devido a } \\
\text { importância do } \\
\text { programa para } \\
\text { o município." }\end{array}$ & $\begin{array}{l}\text { "o empresariado } \\
\text { local tem } \\
\text { iniciativa em } \\
\text { informar quais } \\
\text { são suas } \\
\text { demandas e } \\
\text { interesses em } \\
\text { cursos de } \\
\text { qualificação. } \\
\text { Porém, não } \\
\text { apóia e nem } \\
\text { prioriza a } \\
\text { contratação dos } \\
\text { indivíduos } \\
\text { capacitados." }\end{array}$ & $\begin{array}{l}\text { "a equipe de } \\
\text { qualificação } \\
\text { é pequena" } \\
\text { "o volume de } \\
\text { egresso é } \\
\text { grande e } \\
\text { eles não } \\
\text { dariam conta } \\
\text { de } \\
\text { acompanhar } \\
\text { e monitorar } \\
\text { com } \\
\text { eficiência". } \\
\text { "se os } \\
\text { programas } \\
\text { fossem mais } \\
\text { articulados } \\
\text { com as } \\
\text { necessidade } \\
\text { s do } \\
\text { mercado de } \\
\text { trabalho } \\
\text { local, talvez } \\
\text { o mercado } \\
\text { aproveitasse } \\
\text { e } \\
\text { empregasse } \\
\text { as pessoas } \\
\text { qualificadas". }\end{array}$ & $\begin{array}{l}\text { "a formação foi } \\
\text { irrelevante para } \\
\text { a grande } \\
\text { maioria." } \\
\text { "o mercado está } \\
\text { completamente } \\
\text { alheio a } \\
\text { formação } \\
\text { oferecida pelo } \\
\text { Pronatec." } \\
\text { "Poucas } \\
\text { empresas e } \\
\text { entidades se } \\
\text { interessam em } \\
\text { participar do } \\
\text { Pronatec- } \\
\text { Turismo } \\
\text { viabilizado junto } \\
\text { ao órgão } \\
\text { estadual de } \\
\text { turismo". } \\
\text { "Se o ator social } \\
\text { não está } \\
\text { interessado, há } \\
\text { esvaziando da } \\
\text { ação". }\end{array}$ \\
\hline
\end{tabular}




\begin{tabular}{|c|c|c|c|c|c|c|c|c|}
\hline \multicolumn{3}{|c|}{ CATEGORIAS A PRIORI } & \multicolumn{6}{|c|}{ CATEGORIAS MATERIALISMO HISTORICO-DIALETICO } \\
\hline Categorias & Concepções & Avanços & $\begin{array}{l}\text { Teoria } \\
\text { Prática }\end{array}$ & $\begin{array}{l}\text { Totalidade } \\
\text { fragmentação }\end{array}$ & $\begin{array}{l}\text { Contradição } \\
\text { mediação }\end{array}$ & $\begin{array}{l}\text { Subjetividade } \\
\text { objetividade }\end{array}$ & $\begin{array}{l}\text { Autonomia } \\
\text { dependência }\end{array}$ & $\begin{array}{l}\text { Criticidade } \\
\text { alienação }\end{array}$ \\
\hline $\begin{array}{l}\text { Desenvolvimento } \\
\text { humano/ } \\
\text { Cidadania } \\
\text { E intrínseco ao } \\
\text { desenvolvimento } \\
\text { humano a cidadania } \\
\text { que pressupõe } \\
\text { equidade de } \\
\text { oportunidades. } \\
\text { Tais como ingresso } \\
\text { ao trabalho digno, } \\
\text { acesso à } \\
\text { aposentadoria, à } \\
\text { segurança, à } \\
\text { habitação, à } \\
\text { educação, ao direito, } \\
\text { à cultura e ao lazer, } \\
\text { fatores essenciais } \\
\text { para a consolidação } \\
\text { da cidadania. E } \\
\text { requisitos para o } \\
\text { desenvolvimento } \\
\text { humano, assim como } \\
\text { a educação integral } \\
\text { dos sujeitos, que } \\
\text { tenha como objetivo } \\
\text { a cidadania, a } \\
\text { liberdade, a } \\
\text { autonomia e a } \\
\text { emancipação. }\end{array}$ & $\begin{array}{l}\text { "a entrevistada } \\
\text { a menciona que } \\
\text { procura sempre } \\
\text { dar exemplos e } \\
\text { trabalhar com a } \\
\text { realidade da } \\
\text { cidade e do } \\
\text { estado onde } \\
\text { trabalha. Além } \\
\text { disso, leva } \\
\text { exemplos de } \\
\text { falta de } \\
\text { qualidade no } \\
\text { atendimento de } \\
\text { modo geral. Ela } \\
\text { acredita que um } \\
\text { professor, } \\
\text { independente } \\
\text { da área em que } \\
\text { lecione, deve ter } \\
\text { a preocupação } \\
\text { de discutir } \\
\text { assuntos } \\
\text { relacionados a } \\
\text { cidadania (a } \\
\text { exemplo de } \\
\text { como ser um } \\
\text { cidadão mais } \\
\text { consciente, } \\
\text { respeitar } \\
\text { pessoas } \\
\text { consideradas } \\
\text { "diferentes" ) e, } \\
\text { no caso da área } \\
\text { de } \\
\end{array}$ & $\begin{array}{l}\text { A Gestora } \\
\text { entende que } \\
\text { quando há } \\
\text { aderência ao } \\
\text { tema ou à } \\
\text { proposta, há } \\
\text { sucesso na } \\
\text { formação, } \\
\text { mas isso não } \\
\text { garante a } \\
\text { inserção do } \\
\text { novo } \\
\text { profissional } \\
\text { no mercado } \\
\text { de trabalho, } \\
\text { mesmo } \\
\text { havendo a } \\
\text { necessidade } \\
\text { evidente de } \\
\text { tal } \\
\text { capacitação. }\end{array}$ & $\begin{array}{l}\text { "quanto aos } \\
\text { métodos e } \\
\text { didáticas utilizados, } \\
\text { a professora diz } \\
\text { que procura não } \\
\text { restringir apenas ao } \\
\text { método expositivo, } \\
\text { assim, tenta } \\
\text { incentivar uma } \\
\text { maior participação } \\
\text { do aluno por meio } \\
\text { de estudos de caso } \\
\text { (com discussão), } \\
\text { debates sobre } \\
\text { situações } \\
\text { polêmicas que } \\
\text { aconteceram na } \\
\text { cidade/estado, } \\
\text { encenação 'teatral'. } \\
\text { Quando possível, } \\
\text { ela diz realizar } \\
\text { visitas técnicas a } \\
\text { hotéis com os } \\
\text { alunos." } \\
\text { "a partir de } \\
\text { demandas do } \\
\text { trade." } \\
\text { "houve uma } \\
\text { sondagem junto ao } \\
\text { mercado e ao CNT, } \\
\text { para identificar as } \\
\text { necessidades de } \\
\text { formação }\end{array}$ & $\begin{array}{l}\text { Construção dos } \\
\text { conteúdos: } \\
\text { "Desconheço. } \\
\text { Quando fui } \\
\text { contratada os } \\
\text { cursos já } \\
\text { estavam } \\
\text { montados". } \\
\text { "Alguns cursos } \\
\text { foram } \\
\text { estruturados, as } \\
\text { disciplinas } \\
\text { planejadas, e o } \\
\text { instrutor } \\
\text { chegava apenas } \\
\text { para ministrá- } \\
\text { la”. } \\
\text { "Quanto as } \\
\text { formas de } \\
\text { monitoramento } \\
\text { e avaliação dos } \\
\text { Programas } \\
\text { implantados a } \\
\text { professora } \\
\text { relata existir } \\
\text { uma avaliação } \\
\text { realizada por } \\
\text { meio de } \\
\text { questionário } \\
\text { junto aos alunos } \\
\text { para avaliar os } \\
\text { professores. " }\end{array}$ & $\begin{array}{l}\text { "Ficou } \\
\text { perceptível } \\
\text { falta de } \\
\text { articulação } \\
\text { entre os atores } \\
\text { envolvidos na } \\
\text { dinâmica de } \\
\text { organização e } \\
\text { realização dos } \\
\text { cursos". } \\
\text { "ela percebe } \\
\text { que os alunos } \\
\text { tem } \\
\text { dificuldade em } \\
\text { interpretar as } \\
\text { questões da } \\
\text { prova o que } \\
\text { leva, em } \\
\text { algumas } \\
\text { situações a } \\
\text { notas baixas". } \\
\text { "apenas } \\
\text { monitoraram e } \\
\text { avaliaram o } \\
\text { processo de } \\
\text { desenvolvimen } \\
\text { to dos cursos". }\end{array}$ & $\begin{array}{l}\text { "Desinteresse } \\
\text { dos alunos". } \\
\text { "A professora } \\
\text { optou por adotar } \\
\text { técnicas mais } \\
\text { voltadas para a } \\
\text { prática, } \\
\text { trazendo } \\
\text { diariamente } \\
\text { dinâmicas, } \\
\text { estudo de caso, } \\
\text { "encenações", } \\
\text {...melhorou um } \\
\text { pouco o } \\
\text { interesse dos } \\
\text { alunos (que } \\
\text { priorizava o } \\
\text { recebimento da } \\
\text { bolsa e não o } \\
\text { aprendizado) e } \\
\text { facilitou o } \\
\text { processo de } \\
\text { ensino } \\
\text { aprendizagem. } \\
\text { “ }\end{array}$ & $\begin{array}{l}\text { "a gestão } \\
\text { publica não } \\
\text { tem como } \\
\text { controlar } \\
\text { nada, nem } \\
\text { metodologia, } \\
\text { nem } \\
\text { professor, } \\
\text { nem a } \\
\text { qualidade da } \\
\text { formação, } \\
\text { pois tudo é } \\
\text { de } \\
\text { responsabilid } \\
\text { ade do } \\
\text { ofertante". }\end{array}$ & $\begin{array}{l}\text { "o processo de } \\
\text { avaliação ficou } \\
\text { restrito a } \\
\text { garantir o } \\
\text { repasse dos } \\
\text { recursos". } \\
\text { "A problemática } \\
\text { central deste } \\
\text { tipo de } \\
\text { qualificação não } \\
\text { diz respeito aos } \\
\text { métodos e/ou } \\
\text { didáticas de } \\
\text { sala de aula, e } \\
\text { sim, a } \\
\text { fragilidade de } \\
\text { concepção de } \\
\text { toda a proposta } \\
\text { de } \\
\text { qualificação." }\end{array}$ \\
\hline
\end{tabular}


hospitalidade,

ela diz que isso

fica ainda mais

evidente já que

envolve o ato de

lidar com

pessoas de

modo direto. (habilidades,

competência e

conhecimentos),

foram escolhidas

as formações

prioritárias..., mas é

importante ressalta

que as vagas não

vieram de acordo

com esse pedido.

\begin{tabular}{|l|l|l|l|}
\hline & & & \\
& & & \\
& & & \\
\end{tabular}


Manaus 5 entrevistas (egressos, gestores e instrutores do PRONATEC Turismo)

\begin{tabular}{|c|c|c|c|c|c|c|c|c|}
\hline \multicolumn{3}{|c|}{ CATEGORIAS A PRIORI } & \multicolumn{6}{|c|}{ CATEGORIAS MATERIALISMO HISTORICO-DIALETICO } \\
\hline Categorias & Concepções & Avanços & $\begin{array}{l}\text { Teoria } \\
\text { prática }\end{array}$ & $\begin{array}{l}\text { Totalidade } \\
\text { fragmentação }\end{array}$ & $\begin{array}{l}\text { Contradição } \\
\text { mediação }\end{array}$ & $\begin{array}{l}\text { Subjetividad } \\
\text { e } \\
\text { objetividade }\end{array}$ & $\begin{array}{l}\text { Autonomia } \\
\text { dependência }\end{array}$ & $\begin{array}{l}\text { Criticidade } \\
\text { alienação }\end{array}$ \\
\hline $\begin{array}{l}\text { Inclusão social: } \\
\text { a inclusão dos } \\
\text { sujeitos é } \\
\text { determinante para } \\
\text { uma vida ativa e o } \\
\text { equilíbrio das } \\
\text { oportunidades em } \\
\text { sociedade, } \\
\text { considerando que } \\
\text { essa inclusão } \\
\text { prioritariamente } \\
\text { começa pelo } \\
\text { acesso ao } \\
\text { emprego } \\
\text { qualificante, } \\
\text { possibilitador do } \\
\text { crescimento } \\
\text { profissional, } \\
\text { espaço onde o } \\
\text { trabalhador possa } \\
\text { criar, desenvolver- } \\
\text { se e ter suas } \\
\text { individualidades } \\
\text { respeitadas. } \\
\text { Acesso aos } \\
\text { direitos sociais, } \\
\text { políticos, civis, } \\
\text { econômicos, } \\
\text { culturais e ao } \\
\text { lazer. }\end{array}$ & $\begin{array}{l}\text { Deve-se pensar e } \\
\text { executar políticas } \\
\text { de qualificação } \\
\text { não somente no } \\
\text { turismo como em } \\
\text { todas as áreas } \\
\text { do conhecimento } \\
\text { que alinhem } \\
\text { métodos e } \\
\text { técnicas que são } \\
\text { necessárias e } \\
\text { condizentes ao } \\
\text { mercado de } \\
\text { trabalho } \\
\text { "Ha problemas } \\
\text { na } \\
\text { empregabilidade } \\
\text { e na } \\
\text { formalidade." } \\
\text { "o impacto das } \\
\text { capacitações no } \\
\text { que se refere às } \\
\text { mudanças de } \\
\text { mentalidades de } \\
\text { empresários, } \\
\text { prestação de } \\
\text { serviços e } \\
\text { relação servil } \\
\text { apareceram } \\
\text { como limitadas". }\end{array}$ & $\begin{array}{l}\text { "é } \\
\text { fundamental } \\
\text { que haja } \\
\text { engajamento } \\
\text { entre o } \\
\text { Estado, } \\
\text { Empresários } \\
\text {, Academia } \\
\text { e população } \\
\text { no } \\
\text { planejament } \\
\text { o e } \\
\text { execução de } \\
\text { projetos de } \\
\text { educação." }\end{array}$ & $\begin{array}{l}\text { "foi suficiente } \\
\text { para ajudar nas } \\
\text { necessidades } \\
\text { básicas, mas } \\
\text { ainda muito } \\
\text { pouco para se } \\
\text { trabalhar de } \\
\text { forma } \\
\text { satisfatória. Foi } \\
\text { um curso } \\
\text { introdutório." } \\
\text { "...é necessária } \\
\text { a formação } \\
\text { continuada na } \\
\text { área, pois só } \\
\text { esse curso não } \\
\text { é satisfatório.." } \\
\text { É algo } \\
\text { complexo de } \\
\text { responder, pois } \\
\text { parece algo } \\
\text { verticalizado } \\
\text { pelo governo } \\
\text { federal. Aos } \\
\text { estados e } \\
\text { municípios } \\
\text { cabe apenas a } \\
\text { efetivação dos } \\
\text { cursos. }\end{array}$ & $\begin{array}{l}\text { "O curso realizado } \\
\text { foi satisfatório. } \\
\text { Ressalta a } \\
\text { necessidade de } \\
\text { prática e possíveis } \\
\text { parcerias para } \\
\text { estágio no } \\
\text { mercado de } \\
\text { trabalho." } \\
\text { Dificuldades em } \\
\text { trabalhar assuntos } \\
\text { relacionados com } \\
\text { a pratica } \\
\text { Faltou a prática } \\
\text { para a melhoria do } \\
\text { curso, o que } \\
\text { contribuiu para a } \\
\text { evasão. Outro fator } \\
\text { relevante foi o } \\
\text { atraso no } \\
\text { pagamento da } \\
\text { bolsa-auxílio. } \\
\text { "Novamente } \\
\text { destacou a } \\
\text { necessidade da } \\
\text { prática e parcerias } \\
\text { com empresas." }\end{array}$ & $\begin{array}{l}\text { O curso } \\
\text { possibilita } \\
\text { progressão na } \\
\text { carreira: } \\
\text { "Acredita que } \\
\text { sim. Apesar de } \\
\text { estar } \\
\text { desempregada, } \\
\text { sente-se } \\
\text { preparada para } \\
\text { ingressar no } \\
\text { mercado de } \\
\text { trabalho." } \\
\text { No momento está } \\
\text { desempregada. } \\
\text { "Muitos relatos } \\
\text { deram conta das } \\
\text { especificidades } \\
\text { ainda presentes } \\
\text { no empresariado } \\
\text { do setor na } \\
\text { região. } \\
\text { Extremamente } \\
\text { familiares e que } \\
\text { buscam } \\
\text { profissionais sem } \\
\text { qualificação e, } \\
\text { portanto com } \\
\text { salários ínfimos." }\end{array}$ & $\begin{array}{l}\text { em dúvida } \\
\text { foi o nome } \\
\text { do IFAM no } \\
\text { mercado, } \\
\text { pois se trata } \\
\text { de uma } \\
\text { instituição } \\
\text { muito } \\
\text { respeitada } \\
\text { em todo o } \\
\text { país. } \\
\text { Agregado a } \\
\text { isso temos o } \\
\text { corpo } \\
\text { docente e o } \\
\text { principal que } \\
\text { é o foco do } \\
\text { aluno em } \\
\text { querer se } \\
\text { qualificar. } \\
\text { Observa que } \\
\text { nem todos } \\
\text { tem perfil } \\
\text { para os } \\
\text { cursos e } \\
\text { mercado de } \\
\text { trabalho. }\end{array}$ & $\begin{array}{l}\text { Atua como } \\
\text { organizadora } \\
\text { de eventos. } \\
\text { Ressalta que } \\
\text { tem interesse } \\
\text { em participar de } \\
\text { outros cursos } \\
\text { Pretende seguir } \\
\text { na profissão da } \\
\text { área de eventos } \\
\text { e sempre se } \\
\text { especializar. } \\
\text { "A sociedade } \\
\text { participa } \\
\text { daquilo que é } \\
\text { ofertado". } \\
\text { "muito embora } \\
\text { e reconhecida a } \\
\text { oportunidade } \\
\text { que foi dada } \\
\text { aos } \\
\text { alunos e ao } \\
\text { mercado, caso } \\
\text { o trade } \\
\text { assimilasse } \\
\text { melhor a mão } \\
\text { de obra } \\
\text { formada." }\end{array}$ & $\begin{array}{l}\text { "Sempre há a } \\
\text { barganha de } \\
\text { valores pagos } \\
\text { aos } \\
\text { profissionais." } \\
\text { "Área mal } \\
\text { remunerada". } \\
\text { "Transparece } \\
\text { falta de } \\
\text { planejamento" } \\
\text {. }\end{array}$ \\
\hline
\end{tabular}




\begin{tabular}{|c|c|c|c|c|c|c|c|c|}
\hline \multicolumn{3}{|c|}{ CATEGORIAS A PRIORI } & \multicolumn{6}{|c|}{ CATEGORIAS MATERIALISMO HISTORICO-DIALETICO } \\
\hline Categorias & Concepções & Avanços & $\begin{array}{l}\text { Teoria } \\
\text { prática }\end{array}$ & $\begin{array}{l}\text { Totalidade } \\
\text { fragmentação }\end{array}$ & $\begin{array}{l}\text { Contradiçã } \\
\text { o mediação }\end{array}$ & $\begin{array}{l}\text { Subjetividade } \\
\text { objetividade }\end{array}$ & $\begin{array}{l}\text { Autonomia } \\
\text { dependência }\end{array}$ & $\begin{array}{l}\text { Criticidade } \\
\text { alienação }\end{array}$ \\
\hline $\begin{array}{l}\text { Desenvolvimento } \\
\text { humano/ } \\
\text { Cidadania } \\
\text { E intrínseco ao } \\
\text { desenvolvimento } \\
\text { humano a cidadania } \\
\text { que pressupõe } \\
\text { equidade de } \\
\text { oportunidades. } \\
\text { Tais como ingresso } \\
\text { ao trabalho digno, } \\
\text { acesso à } \\
\text { aposentadoria, à } \\
\text { segurança, à } \\
\text { habitação, à } \\
\text { educação, ao direito, } \\
\text { à cultura e ao lazer, } \\
\text { fatores essenciais } \\
\text { para a consolidação } \\
\text { da cidadania. E } \\
\text { requisitos para o } \\
\text { desenvolvimento } \\
\text { humano, assim como } \\
\text { a educação integral } \\
\text { dos sujeitos, que } \\
\text { tenha como objetivo a } \\
\text { cidadania, a } \\
\text { liberdade, a } \\
\text { autonomia e a } \\
\text { emancipação. }\end{array}$ & $\begin{array}{l}\text { O profissional } \\
\text { deve } \\
\text { compreender que } \\
\text { o turismo é } \\
\text { atividade de } \\
\text { serviços e que o } \\
\text { elemento } \\
\text { principal é o } \\
\text { turista e suas } \\
\text { motivações } \\
\text { (cidadão com } \\
\text { direitos e } \\
\text { deveres) o qual } \\
\text { está integrado ao } \\
\text { destino turístico } \\
\text { cujos moradores } \\
\text { locais também } \\
\text { possuem direitos } \\
\text { e deveres. } \\
\\
\text { "nuances } \\
\text { importantes do } \\
\text { aprendizado } \\
\text { evidenciadas na } \\
\text { proposta, no } \\
\text { sentido de } \\
\text { formação de } \\
\text { cidadania, } \\
\text { debates de } \\
\text { gênero, etc, } \\
\text { tenham sido } \\
\text { prejudicas." }\end{array}$ & & $\begin{array}{l}\text { "Foi importante, } \\
\text { mas, ressalta a } \\
\text { rapidez nos } \\
\text { cursos } \\
\text { oferecidos na } \\
\text { área." } \\
\text { "Considera o } \\
\text { curso muito } \\
\text { bom e } \\
\text { gratificante." } \\
\text { "Possuir mais } \\
\text { atividades } \\
\text { práticas." } \\
\text { "Faltaram mais } \\
\text { visitas } \\
\text { técnicas." } \\
\text { "O curso } \\
\text { possibilitou a } \\
\text { ampliação de } \\
\text { conhecimentos" } \\
\text { "Curso foi } \\
\text { introdutório". } \\
\text { "o material para } \\
\text { os cursos } \\
\text { se resume ao } \\
\text { professor e } \\
\text { apostiladas". } \\
\text { atas }\end{array}$ & $\begin{array}{l}\text { "carga horária } \\
\text { possa ser ampliada } \\
\text { em virtude da } \\
\text { amplitude de } \\
\text { assuntos } \\
\text { relacionados ao } \\
\text { tema". } \\
\text { "Esbarra na } \\
\text { qualificação } \\
\text { exigida pelo } \\
\text { mercado de } \\
\text { trabalho e muitas } \\
\text { vezes pela } \\
\text { ausência de } \\
\text { oportunidades." } \\
\text { "a ausência de } \\
\text { uma unidade nos } \\
\text { processos de } \\
\text { criação } \\
\text { dos cursos, } \\
\text { evidenciado a } \\
\text { ausência de um } \\
\text { programa mais } \\
\text { estruturado". } \\
\text { "estes cursos são } \\
\text { propostas, de cima } \\
\text { para } \\
\text { baixo, sem atender } \\
\text { as necessidades } \\
\text { da comunidade." }\end{array}$ & $\begin{array}{l}\text { "A falta de } \\
\text { recursos } \\
\text { para a } \\
\text { qualificaçã } \\
\text { o } \\
\text { adequada, } \\
\text { como } \\
\text { locais, } \\
\text { visitas } \\
\text { técnicas e } \\
\text { outros. }\end{array}$ & & $\begin{array}{l}\text { Formação foi } \\
\text { de extrema } \\
\text { importância } \\
\text { para área de } \\
\text { atuação. Fez } \\
\text { o curso de } \\
\text { organizador } \\
\text { de eventos, } \\
\text { identificou-se } \\
\text { e atualmente } \\
\text { trabalha na } \\
\text { área. } \\
\text { Foi motivador } \\
\text { para buscar } \\
\text { outros níveis } \\
\text { de } \\
\text { escolaridade. } \\
\text { "fiz outro na } \\
\text { área." }\end{array}$ & $\begin{array}{l}\text { "foi muito } \\
\text { positivo, poderia } \\
\text { ocorrer da } \\
\text { mesma forma, } \\
\text { apenas com a } \\
\text { ampliação para } \\
\text { a prática dos } \\
\text { alunos e talvez } \\
\text { um maior tempo } \\
\text { de duração." }\end{array}$ \\
\hline
\end{tabular}

3 egressos: 1 trabalha no setor, os 3 já cursam curso superior em outras áreas 
Curitiba - 6 entrevistas (egressos, gestores e instrutores do PRONATEC Turismo)

\begin{tabular}{|c|c|c|c|c|c|c|c|c|}
\hline \multicolumn{3}{|c|}{ CATEGORIAS A PRIORI } & \multicolumn{6}{|c|}{ CATEGORIAS MATERIALISMO HISTORICO-DIALETICO } \\
\hline Categorias & Concepções & Avanços & $\begin{array}{l}\text { Teoria } \\
\text { prática }\end{array}$ & $\begin{array}{l}\text { Totalidade } \\
\text { fragmentação }\end{array}$ & $\begin{array}{l}\text { Contradição } \\
\text { mediação }\end{array}$ & $\begin{array}{l}\text { Subjetividade } \\
\text { objetividade }\end{array}$ & $\begin{array}{l}\text { Autonomia } \\
\text { dependência }\end{array}$ & $\begin{array}{l}\text { Criticidade } \\
\text { alienação }\end{array}$ \\
\hline $\begin{array}{l}\text { Inclusão social: } \\
\text { a inclusão dos } \\
\text { sujeitos é } \\
\text { determinante para } \\
\text { uma vida ativa e o } \\
\text { equilíbrio das } \\
\text { oportunidades em } \\
\text { sociedade, } \\
\text { considerando que } \\
\text { essa inclusão } \\
\text { prioritariamente } \\
\text { começa pelo acesso } \\
\text { ao emprego } \\
\text { qualificante, } \\
\text { possibilitador do } \\
\text { crescimento } \\
\text { profissional, espaço } \\
\text { onde o trabalhador } \\
\text { possa criar, } \\
\text { desenvolver-se e ter } \\
\text { suas individualidades } \\
\text { respeitadas. Acesso } \\
\text { aos direitos sociais, } \\
\text { políticos, civis, } \\
\text { econômicos, } \\
\text { culturais e ao lazer. }\end{array}$ & $\begin{array}{l}\text { "O que } \\
\text { poderia ter } \\
\text { sido... era } \\
\text { realizar uma } \\
\text { avaliação } \\
\text { com os } \\
\text { concluintes } \\
\text { após o } \\
\text { término do } \\
\text { curso. E } \\
\text { verificar se } \\
\text { conseguiram } \\
\text { um } \\
\text { emprego..." }\end{array}$ & $\begin{array}{l}\text { "falhamos } \\
\text { em não ter } \\
\text { um } \\
\text { monitoramen } \\
\text { to, } \\
\text { encaminham } \\
\text { ento para um } \\
\text { emprego". }\end{array}$ & $\begin{array}{l}\text { Porque as } \\
\text { desistências } \\
\text { ocorreram... } \\
\text { "arranjar } \\
\text { emprego, } \\
\text { desinteresse } \\
\text { pelo tema e } \\
\text { desinteresse } \\
\text { do aluno". } \\
\text { "o mau } \\
\text { direcionament } \\
\text { o dos } \\
\text { alunos"... } \\
\text { "...lamentei o } \\
\text { insucesso do } \\
\text { Programa. O } \\
\text { Mercado está } \\
\text { carente de } \\
\text { profissionais } \\
\text { qualificados ." }\end{array}$ & $\begin{array}{l}\text { "Acredito que um } \\
\text { curso de qualificação } \\
\text { em turismo deve } \\
\text { abranger, de forma } \\
\text { global e } \\
\text { interdisciplinar, } \\
\text { aspectos econômicos, } \\
\text { políticos e sociais da } \\
\text { atividade turística na } \\
\text { localidade, trazendo } \\
\text { exemplos práticos e } \\
\text { reais”. } \\
\text { “... não vejo que tenha } \\
\text { relação direta com o } \\
\text { retorno a educação } \\
\text { formal, porque tem } \\
\text { público diferente e um } \\
\text { foco diferente. Eu me } \\
\text { preocupo com a } \\
\text { supervalorização que } \\
\text { atribuem ao pronatec. } \\
\text { Um curso de } 1 \text { ano e } \\
\text { meio não vai ser igual } \\
\text { a um curso de } 3 \\
\text { meses". }\end{array}$ & $\begin{array}{l}\text { "Se hoje eu } \\
\text { estivesse } \\
\text { atuando como } \\
\text { Guia, acredito } \\
\text { que estaria } \\
\text { muito bem } \\
\text { preparada. As } \\
\text { saídas } \\
\text { técnicas foram } \\
\text { muito } \\
\text { importante } \\
\text { para } \\
\text { conhecermos } \\
\text { destinos: o } \\
\text { que fazer, por } \\
\text { onde andar" } \\
\text { "Acredito que } \\
\text { os alunos } \\
\text { chegaram ao } \\
\text { curso pela } \\
\text { necessidade } \\
\text { de receber o } \\
\text { seguro } \\
\text { desemprego". }\end{array}$ & $\begin{array}{l}\text { "Não estou } \\
\text { empregado" } \\
\text { "Turismo não é } \\
\text { muito a minha } \\
\text { abordagem". } \\
\text { Futuramente } \\
\text { quem sabe } \\
\text { consigo aliar o } \\
\text { turismo, } \\
\text { comércio exterior } \\
\text { e eventos. } \\
\text { Tenho projetos } \\
\text { para isso" }\end{array}$ & $\begin{array}{l}\text { "A } \\
\text { instabilidade } \\
\text { do mercado } \\
\text { impede o } \\
\text { crescimento } \\
\text { pessoal e } \\
\text { profissional" } \\
\text { "Então o } \\
\text { curso é uma } \\
\text { oportunidade } \\
\text { para o aluno } \\
\text { e traz uma } \\
\text { perspectiva } \\
\text { de } \\
\text { crescimento } \\
\text { pessoal, e } \\
\text { tem um } \\
\text { grande } \\
\text { valor". }\end{array}$ & $\begin{array}{l}\text { "Em função de } \\
\text { muitos alunos } \\
\text { terem sido } \\
\text { direcionados de } \\
\text { forma errada } \\
\text { (ou faziam o } \\
\text { curso, ou não } \\
\text { receberiam o } \\
\text { seguro } \\
\text { desemprego), } \\
\text { muitos que não } \\
\text { tem vocação } \\
\text { para a área se } \\
\text { desmotivaram". } \\
\text { "Esse período } \\
\text { de } 3 \text { meses não } \\
\text { vai transformar } \\
\text { uma pessoa } \\
\text { leiga em um } \\
\text { organizador de } \\
\text { eventos... Os } \\
\text { cursos podem } \\
\text { ser mais } \\
\text { produtivos para } \\
\text { cursos mais } \\
\text { básicos, } \\
\text { como } \\
\text { recepcionista } \\
\text { e auxiliar de } \\
\text { cozinha". }\end{array}$ \\
\hline
\end{tabular}




\begin{tabular}{|c|c|c|c|c|c|c|c|c|}
\hline \multicolumn{3}{|c|}{ CATEGORIAS A PRIORI } & \multicolumn{6}{|c|}{ CATEGORIAS MATERIALISMO HISTORICO-DIALETICO I } \\
\hline Categorias & Concepções & Avanços & $\begin{array}{l}\text { Teoria } \\
\text { prática }\end{array}$ & $\begin{array}{l}\text { Totalidade } \\
\text { fragmentação }\end{array}$ & $\begin{array}{l}\text { Contradição } \\
\text { mediação }\end{array}$ & $\begin{array}{l}\text { Subjetividade } \\
\text { objetividade }\end{array}$ & $\begin{array}{l}\text { Autonomia } \\
\text { dependência }\end{array}$ & $\begin{array}{l}\text { Criticidade } \\
\text { alienação }\end{array}$ \\
\hline $\begin{array}{l}\text { Desenvolvimento } \\
\text { humano/ } \\
\text { Cidadania } \\
\text { E intrínseco ao } \\
\text { desenvolvimento } \\
\text { humano a } \\
\text { cidadania que } \\
\text { pressupõe } \\
\text { equidade de } \\
\text { oportunidades. } \\
\text { Tais como ingresso } \\
\text { ao trabalho digno, } \\
\text { acesso à } \\
\text { aposentadoria, à } \\
\text { segurança, à } \\
\text { habitação, à } \\
\text { educação, ao } \\
\text { direito, à cultura e } \\
\text { ao lazer, fatores } \\
\text { essenciais para a } \\
\text { consolidação da } \\
\text { cidadania. E } \\
\text { requisitos para o } \\
\text { desenvolvimento } \\
\text { humano, assim } \\
\text { como a educação } \\
\text { integral dos } \\
\text { sujeitos, que tenha } \\
\text { como objetivo a } \\
\text { cidadania, a } \\
\text { liberdade, a } \\
\text { autonomia e a } \\
\text { emancipação. }\end{array}$ & $\begin{array}{l}\text { "Vivo minha } \\
\text { cidadania } \\
\text { respeitando } \\
\text { leis e regras } \\
\text { de convívio } \\
\text { social, mas } \\
\text { nunca me } \\
\text { engajei em } \\
\text { associações } \\
\text { de } \\
\text { moradores } \\
\text { do bairro, ou } \\
\text { debati sobre } \\
\text { problemas } \\
\text { sociais } \\
\text { locais". } \\
\text { "Os cursos } \\
\text { são de curto } \\
\text { período, } \\
\text { então a } \\
\text { questão de } \\
\text { cidadania } \\
\text { entra no } \\
\text { ditado que o } \\
\text { trabalho } \\
\text { dignifica o } \\
\text { homem". }\end{array}$ & $\begin{array}{l}\text { "A } \\
\text { escolaridade } \\
\text { dos alunos é } \\
\text { diferente, é } \\
\text { necessário } \\
\text { que tenha um } \\
\text { professor de } \\
\text { empreendedor } \\
\text { ismo um } \\
\text { psicólogo, mas } \\
\text { isso foi um } \\
\text { aprendizado } \\
\text { junto ao } \\
\text { programa". }\end{array}$ & $\begin{array}{l}\text { "Acredito que a } \\
\text { valorização do } \\
\text { profissional em } \\
\text { relação ao } \\
\text { turismo e ao } \\
\text { descobrimento } \\
\text { da importância } \\
\text { do turismo tanto } \\
\text { econômica } \\
\text { quanto social. } \\
\text { Mas isso, nós } \\
\text { temos que ver } \\
\text { que nem todos } \\
\text { os alunos que } \\
\text { vem fazer o } \\
\text { curso são } \\
\text { ligados a área. } \\
\text { E tem uma } \\
\text { visão apenas de } \\
\text { passeio, e que } \\
\text { não é isso o } \\
\text { turismo". } \\
\text { "Não foi } \\
\text { realizada } \\
\text { nenhuma } \\
\text { avaliação". }\end{array}$ & $\begin{array}{l}\text { "Parcialmente, como } \\
\text { a área é muito } \\
\text { ampla, ficaram } \\
\text { muitos vazios de } \\
\text { conteúdos a serem } \\
\text { ministrados". }\end{array}$ & & $\begin{array}{l}\text { "Os professores } \\
\text { indicaram o } \\
\text { conteúdo } \\
\text { necessário". }\end{array}$ & $\begin{array}{l}\text { "Estou } \\
\text { cursando } \\
\text { Turismo na } \\
\text { UFPR" }\end{array}$ & $\begin{array}{l}\text { Os cursos } \\
\text { "não } \\
\text { abrangem a } \\
\text { todas as } \\
\text { necessidades } \\
\text { relacionadas } \\
\text { ao tema, ou ao } \\
\text { cargo". }\end{array}$ \\
\hline
\end{tabular}


APÊNDICE B - CATEGORIA EdUCAÇÃo PROFISSIONAL POSSIBILITADORA DA CONSTRUÇÃo dE CARREIRAS NO SETOR (BOAS PRÁTICAS)

\begin{tabular}{|c|c|c|c|c|c|c|c|c|}
\hline \multicolumn{3}{|c|}{ CATEGORIAS A PRIORI } & \multicolumn{6}{|c|}{ CATEGORIAS MATERIALISMO HISTORICO-DIALETICO } \\
\hline Categorias & Concepções & Avanços & $\begin{array}{l}\text { Teoria } \\
\text { prática }\end{array}$ & $\begin{array}{c}\text { Totalidade } \\
\text { fragmentação }\end{array}$ & $\begin{array}{l}\text { Contradição } \\
\text { mediação }\end{array}$ & $\begin{array}{c}\text { Subjetividade } \\
\text { objetividade }\end{array}$ & $\begin{array}{c}\text { Autonomia } \\
\text { dependência }\end{array}$ & $\begin{array}{l}\text { Criticidade } \\
\text { alienação }\end{array}$ \\
\hline $\begin{array}{l}\text { Educação profissional } \\
\text { possibilitadora da construção de } \\
\text { carreiras no setor: concepções de } \\
\text { educação/formação profissional, } \\
\text { focada nos sujeitos e não apenas } \\
\text { na produção e no capital. Em que } \\
\text { sejam valorizadas as } \\
\text { potencialidades humanas, a } \\
\text { educação problematizadora, } \\
\text { emancipatória e cidadã, que } \\
\text { permita desenvolver } \\
\text { competências não só para o } \\
\text { trabalho, como também para a } \\
\text { vida, em detrimento da educação } \\
\text { bancária, focada em treinamento. } \\
\text { Com uma nova postura na } \\
\text { educação profissional será } \\
\text { possível enxergar o trabalho no } \\
\text { Turismo como oportunidade } \\
\text { interessante, gratificante e } \\
\text { criativa, no qual os sujeitos } \\
\text { podem desenvolver-se } \\
\text { permanentemente pelas relações } \\
\text { de troca e aprendizado constante } \\
\text { que o setor pode proporcionar. } \\
\text { Pela formação de um profissional } \\
\text { ativo, crítico, consciente e } \\
\text { participativo poderá se mudar a } \\
\text { visão empresarial e lutar pela } \\
\text { valorização e o reconhecimento } \\
\text { profissional. }\end{array}$ & & $\begin{array}{l}\text { "Tenho } \\
\text { vontade de } \\
\text { voltar a } \\
\text { estudar, } \\
\text { realizar uma } \\
\text { graduação na } \\
\text { área." } \\
\text { "foi possível } \\
\text { despertar para } \\
\text { a área de } \\
\text { turismo a partir } \\
\text { desse curso." } \\
\text { "Estou } \\
\text { cursando } \\
\text { Turismo na } \\
\text { UFPR" } \\
\text { "fiz um curso } \\
\text { de somellier } \\
\text { após o de } \\
\text { bartender" } \\
\text { Fez o curso de } \\
\text { organizador de } \\
\text { eventos, } \\
\text { identificou-se } \\
\text { e atualmente } \\
\text { trabalha na } \\
\text { área. }\end{array}$ & $\begin{array}{l}\text { "O curso } \\
\text { possibilitou a } \\
\text { entrada no curso } \\
\text { de tecnologia de } \\
\text { eventos no IFBA". } \\
\text { "Após o curso } \\
\text { estou fazendo } \\
\text { tecnologia em } \\
\text { eventos." } \\
\text { "voltei a estudar } \\
\text { no IFBA, curso } \\
\text { tecnológico em } \\
\text { meios de } \\
\text { hospedagens." } \\
\text { "com a base do } \\
\text { curso consegui } \\
\text { passar no } \\
\text { vestibular." } \\
\text { "o curso é uma } \\
\text { oportunidade para } \\
\text { o aluno e traz } \\
\text { uma perspectiva } \\
\text { de crescimento } \\
\text { pessoal, e tem } \\
\text { um grande valor". }\end{array}$ & $\begin{array}{l}\text { "O egresso } \\
\text { informa que o } \\
\text { curso ofertado } \\
\text { pela UnP } \\
\text { possibilitou o } \\
\text { seu } \\
\text { conhecimentos } \\
\text { da área do } \\
\text { Turismo e foi o } \\
\text { motivo que o } \\
\text { incentivou a } \\
\text { cursar a } \\
\text { graduação em } \\
\text { Turismo. } \\
\text { "Formação foi } \\
\text { de extrema } \\
\text { importância } \\
\text { para área de } \\
\text { atuação". } \\
\text { "Foi motivador } \\
\text { para buscar } \\
\text { outros níveis de } \\
\text { escolaridade. " }\end{array}$ & $\begin{array}{l}\text { "Consegui } \\
\text { trabalho na } \\
\text { área mas } \\
\text { não fiquei." } \\
\text { "Aprendi } \\
\text { certas coisas } \\
\text { que eu não } \\
\text { conhecia, eu } \\
\text { tenho uma } \\
\text { outra visão." }\end{array}$ & $\begin{array}{l}\text { Ressalta que } \\
\text { tem interesse } \\
\text { em participar } \\
\text { de outros } \\
\text { cursos } \\
\text { Pretende } \\
\text { seguir na } \\
\text { profissão da } \\
\text { área de } \\
\text { eventos e } \\
\text { sempre se } \\
\text { especializar. } \\
\text { "pensei em } \\
\text { fazer } \\
\text { graduação } \\
\text { em turismo, } \\
\text { mas não } \\
\text { posso } \\
\text { financeirame } \\
\text { nte." }\end{array}$ & $\begin{array}{l}\text { "trabalho } \\
\text { como } \\
\text { garçonete." } \\
\text { "quero } \\
\text { trabalhar } \\
\text { nessa área." } \\
\text { "fiz um } \\
\text { segundo } \\
\text { curso no } \\
\text { setor." } \\
\text { "Sim, estou } \\
\text { fazendo esse } \\
\text { novo curso." } \\
\text { "Consegui } \\
\text { estágio após } \\
\text { o curso e } \\
\text { trabalho } \\
\text { indiretamente } \\
\text { na área." } \\
\text { "fiz outros } \\
\text { cursos na } \\
\text { área." } \\
\text { "fiz outro na } \\
\text { área." }\end{array}$ & \\
\hline
\end{tabular}


APÊNDICE C - QUANTIDADE DE EGRESSOS PRONATEC ENTREVISTADOS (ESCOLARIDADE)

\begin{tabular}{|c|c|c|c|c|}
\hline Cidade-sede & Trabalha no setor & Não trabalha no setor & $\begin{array}{l}\text { Ensino superior } \\
\text { incompleto }\end{array}$ & $\begin{array}{l}\text { Ensino superior } \\
\text { completo }\end{array}$ \\
\hline BSB & 1 & 2 & 2 & 1 \\
\hline CUIABA & - & 2 & & \\
\hline $\mathrm{BH}$ & 2 (1 freela) & - & 2 & $4+2$ \\
\hline SP & - & - & - & - \\
\hline SALVADOR & 1 & 2 & 3 & \\
\hline POA & $\begin{array}{c}3 \text { pronatec empresa (1 } \\
\text { freelance) }\end{array}$ & - & - & - \\
\hline FORTALEZA & - & - & - & - \\
\hline RJ & $\begin{array}{l}2 \text { (1 freela e } 1 \\
\text { empresário) }\end{array}$ & 3 & - & - \\
\hline NATAL & 1 & 2 & 2 & \\
\hline MANAUS & 1 & 2 & - & - \\
\hline RECIFE & - & - & - & - \\
\hline CURITIBA & 1 freela & 1 & 1 & 1 \\
\hline TOTAL & 6 (4 freela) & 14 & 10 & 8 \\
\hline
\end{tabular}

TOTAL GERAL: 30 egressos 
APÊNDICE D - CORRELAÇÃo CURSOS PRONATEC TURISMO X NORMAS

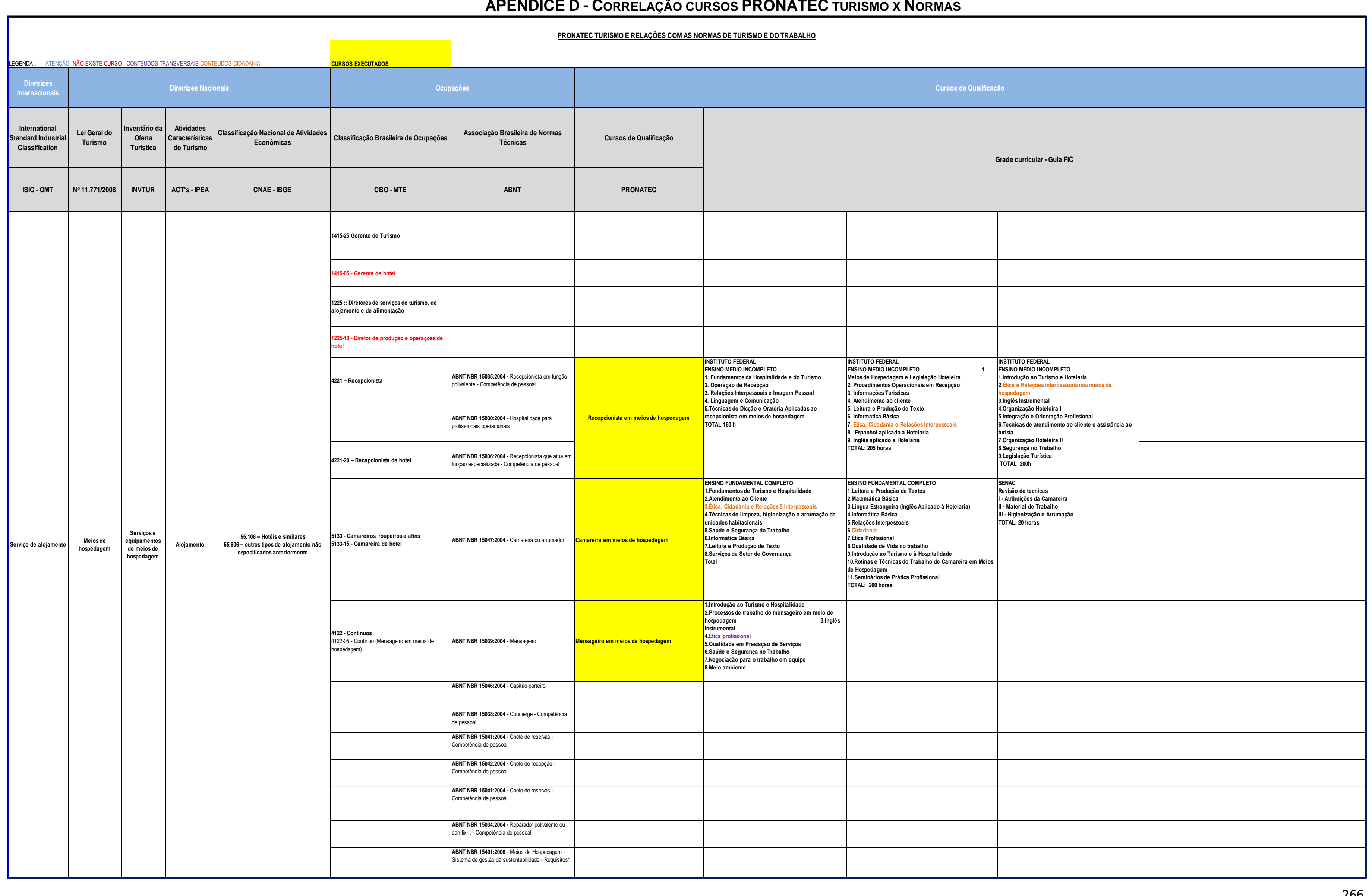




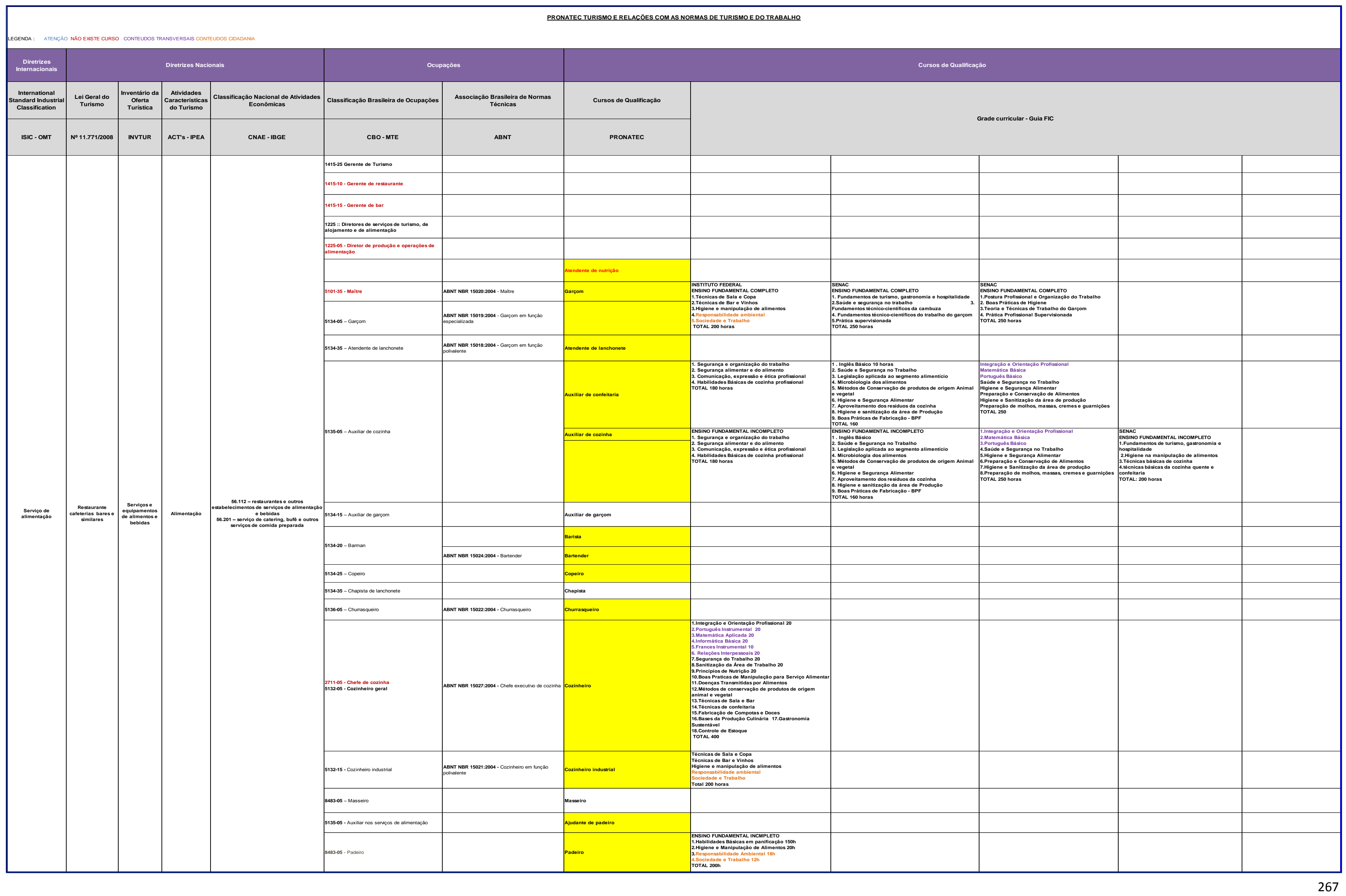




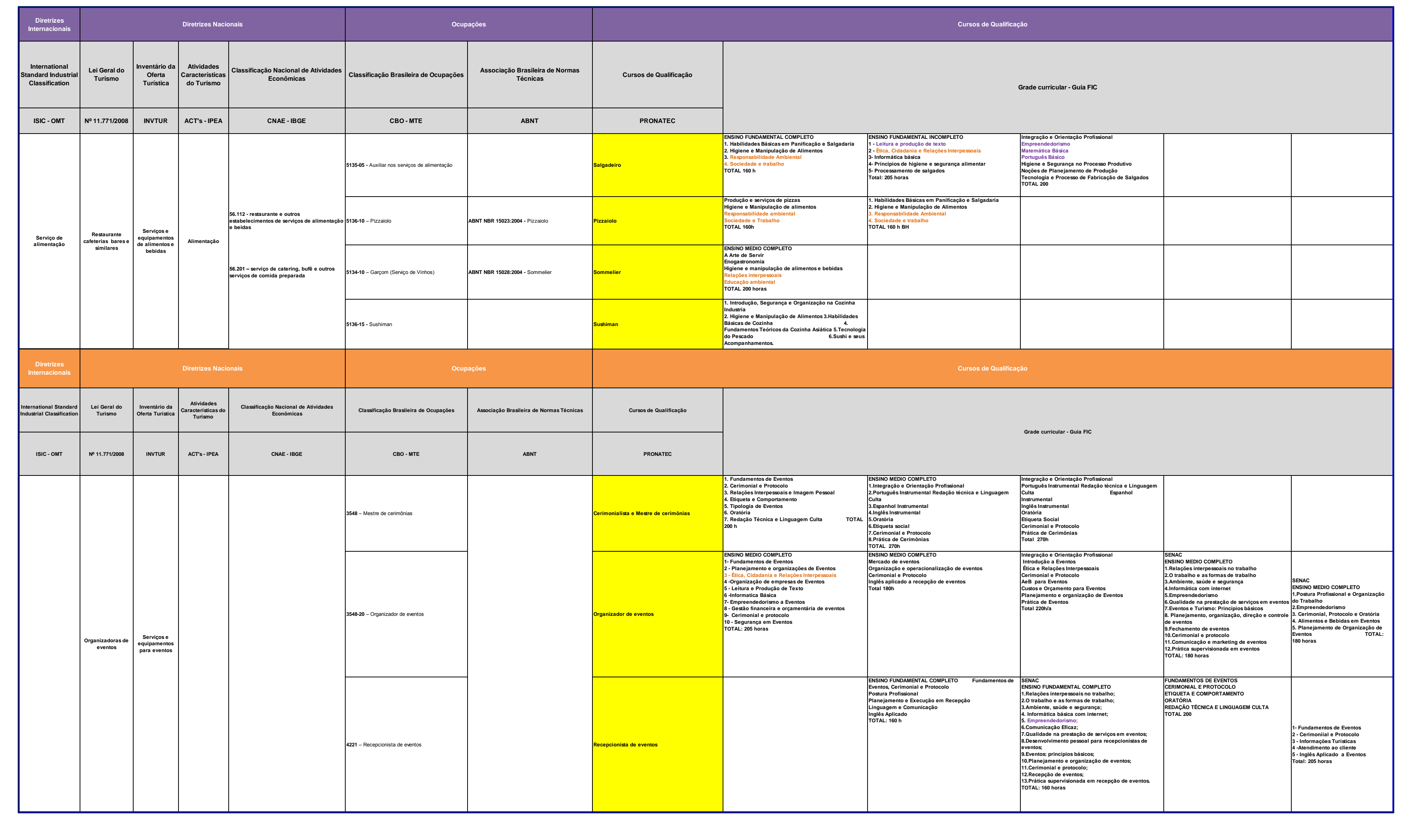




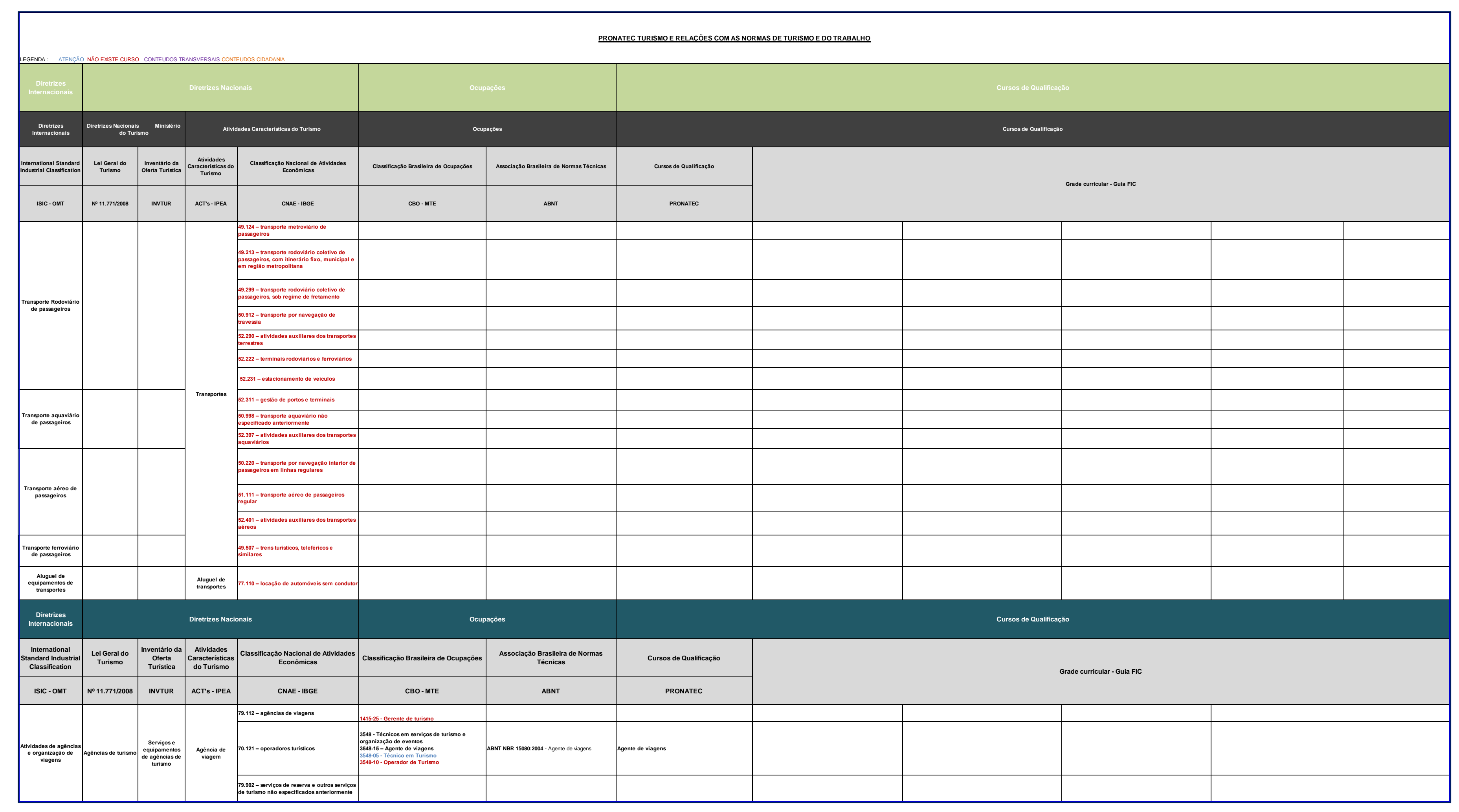




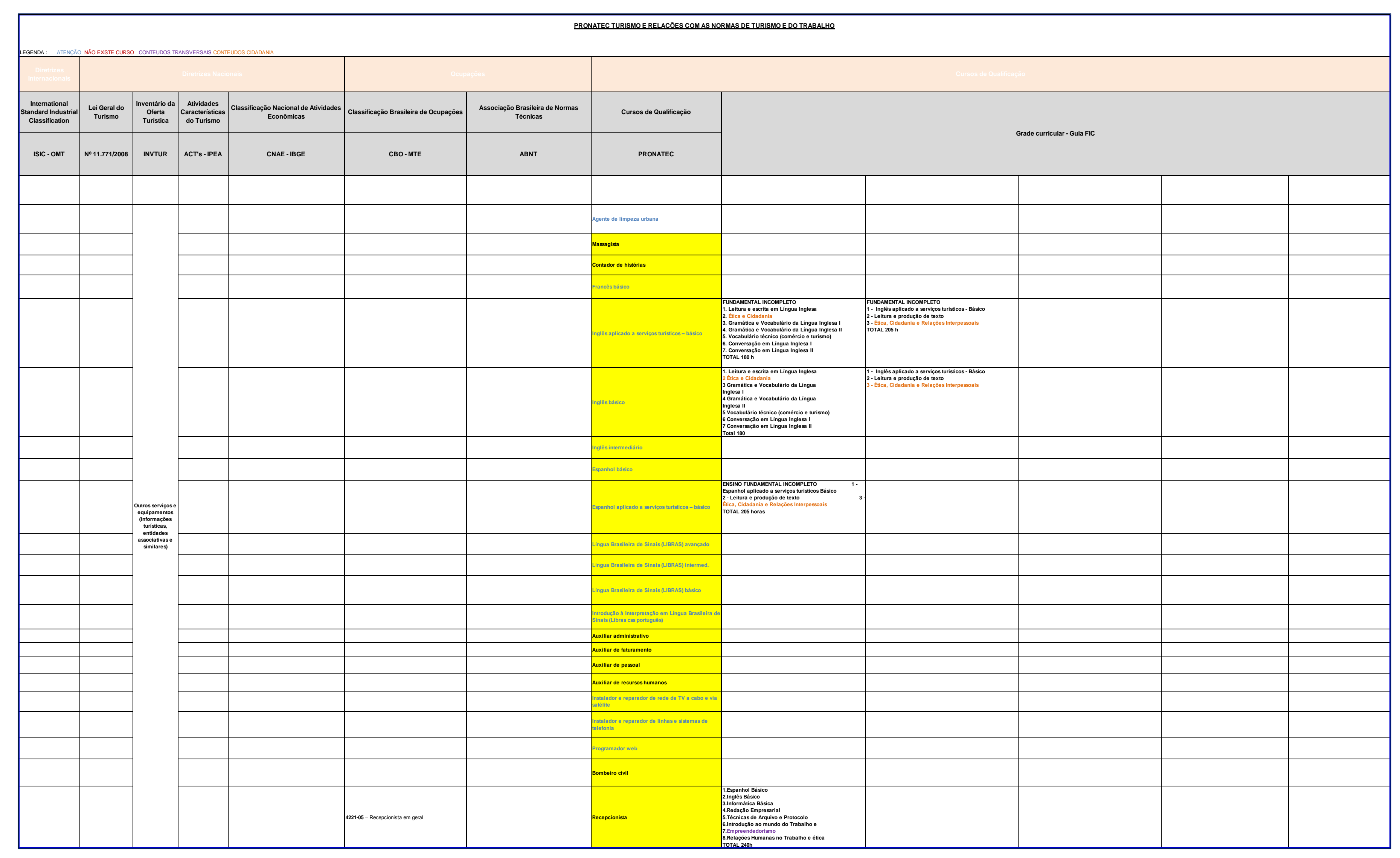




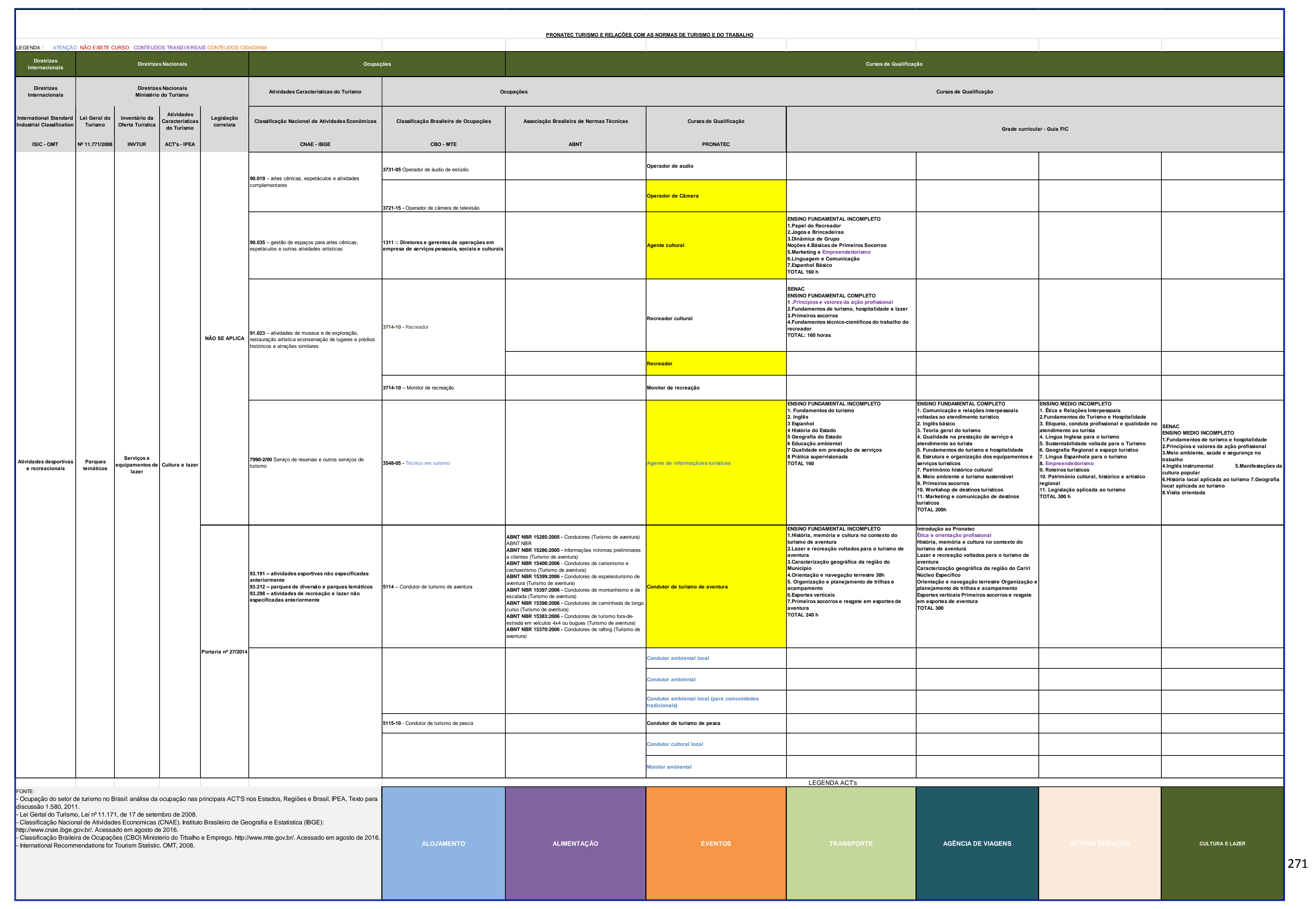

